\title{
The Status of Tibet in International Law - From the 1840s to the 1950s
}

Chenyu Wang 
Copyright (C) 2021, C. Wang

All rights reserved. No part of this book may be reproduced, stored in a retrieval system or transmitted in any form or by any means, electronic, recording, mechanical, by print or otherwise without prior written permission from the author. 


\title{
The Status of Tibet in International Law - From the 1840s to the 1950s
}

\author{
De Status van Tibet in Internationaal Recht - Van de \\ Jaren 1840 tot de Jaren 1950 \\ (met een samenvatting in het Nederlands)
}

\section{Proefschrift}

ter verkrijging van de graad van doctor aan de Universiteit Utrecht op gezag van de rector magnificus, prof.dr. H.R.B.M. Kummeling, ingevolge het besluit van het college voor promoties in het openbaar te verdedigen op

maandag 22 november 2021 des ochtends te 10.15 uur

door

\section{Chenyu Wang}

geboren op 4 november 1989

te Anhui, China 


\section{Promotor:}

Prof. dr. C.M.J. Ryngaert

\section{Copromotor:}

Dr. O. Spijkers

This research is funded by the China Scholarship Council (CSC No. 201607080023). 


\section{ACKNOWLEDGMENTS}

After five years $\mathrm{PhD}$ training at Utrecht University, I finally completed this doctoral thesis and it would not have been possible without the support and guidance that I received from many people.

First and foremost, I am deeply grateful for the continuous support, encouragement and patience of my supervisors, Professor Cedric Ryngaert and Dr. Otto Spijkers. They have supported me not only by providing an opportunity to pursue this $\mathrm{PhD}$ research in the Netherlands, but also academically and emotionally through arranging monthly discussions. And during the most difficult times when writing this thesis, they gave me the professional advice and the freedom I needed to move on. Without their insightful comments and constant trust, this $\mathrm{PhD}$ thesis would not have been completed.

I am indebted to the China Scholarship Council (CSC) for funding my four-years $\mathrm{PhD}$ research in the Netherlands, which removed financial concerns from my decision to embark on this journey. I would also like to acknowledge the IER department of the School of Law of UU for helping me solve the practical matters in my work and providing financial aid for my participation in academic conferences.

I greatly appreciate the thought-provoking comments from the assessing committee of this thesis, and their positive feedback enabled me to successfully move on to the stage of public defence. So special thanks to Prof. dr. Matthew Craven of School of African and Oriental Studies of University of London, Prof. dr. Randall Lesaffer of KU Leuven, Prof. dr. Tom Zwart of Utrecht University, Prof. dr. Seline Trevisanut of Utrecht University, and Prof. dr. Deng Lie of Zhongnan University of Economics and Law, who triggered my interest in public international law and guided me to the path of Tibet research.

I would also like to acknowledge my dear friends and colleagues in Utrecht for their pleasant company and selfless help: Wen Duan, Chuxiao Yu, Chao Jing, Laura Íñigo Álvarez, Minh Tran, Andrea Stefanus, Liping Dai, Kai Liu, Congrui Qiao, Tao Tang, Tong $\mathrm{Xu}$, Chengjun Zheng, and Eva Simkens who contributed to the improvement of the Dutch summary of my thesis. In addition, thanks to my flatmate - Yu Bo for getting along well with me. 
Last but not least, during my five years in the Netherlands, my family gave me nothing but support, day after day, both emotionally and financially: my love and gratitude for them can hardly be expressed in words. I dedicate this thesis to my parents - Wang Mingsheng and Sun Yalan.

September 2021, Hefei

Chenyu Wang 


\section{Table of Contents}

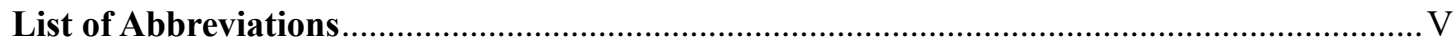

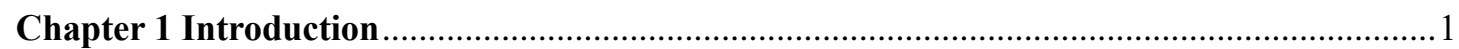

1.1 Background and Research Question ................................................................... 1

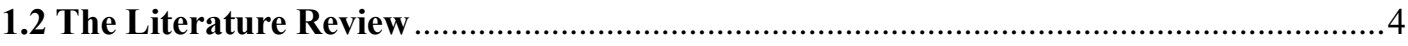

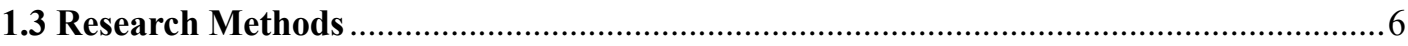

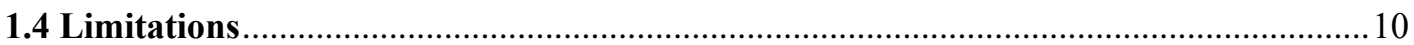

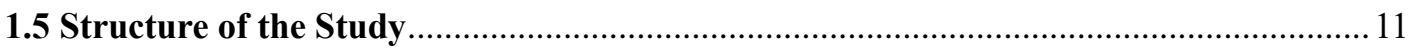

Chapter 2 The Early Relations Between Imperial China and Tibet under the Tribute System .14

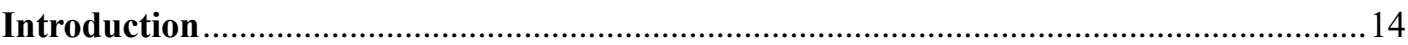

2.1 The Chinese World Order — the Tribute System ................................................... 15

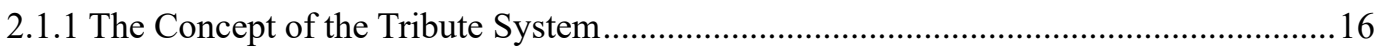

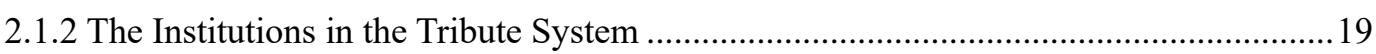

2.1.3 The Influence of the Tribute System on Shaping the Boundary.................................22

2.2 The Early Sino-Tibetan Interactions Under the Tribute System-From the Tang

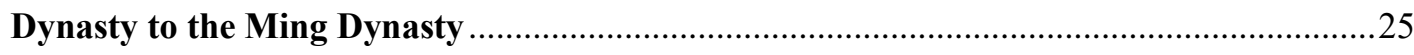

2.2.1 The Sino-Tibetan Relations in the Tang Dynasty.....................................................26

2.2.2 The Sino-Tibetan Relations in the Yuan Dynasty........................................................27

2.2.2.1 The Yuan - A Mongol Empire or a Chinese Dynasty? .........................................28

2.2.2.2 The Status of Tibet in Yuan-Tibetan Relations..................................................... 30

2.2.3 The Sino-Tibetan Relations in the Ming Dynasty ....................................................... 32

2.3 The Status of Tibet in the Qing Dynasty .........................................................3

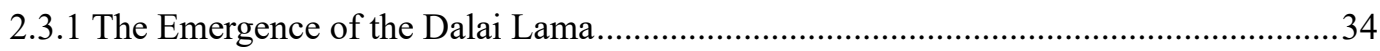

2.3.2 The Qing's Early Involvement in Tibetan Affairs ......................................................35

2.3.3 The Establishment of Qing's Rule in Tibet ....................................................... 37

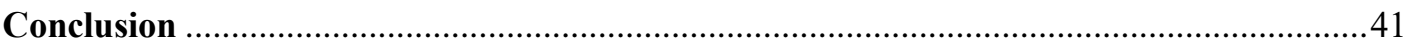

Chapter 3 The Status of Tibet Before the Twentieth Century - From the Perspective of

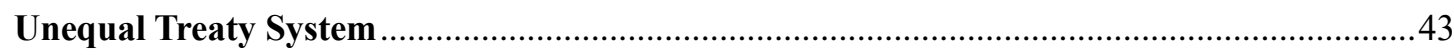

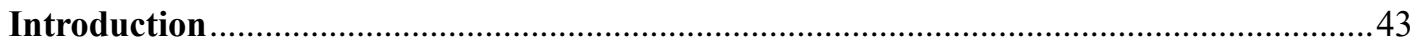

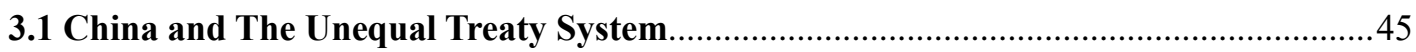

3.1.1 China's Approach to International Law Since the $1840 \mathrm{~s}$.........................................45

3.1.2 The Validity of Treaties Between China and Western Powers in the Nineteenth Century

3.2 The Status of Tibet in Sino-British Negotiations .................................................53

3.2.1 Early British Involvement in Tibet.......................................................................5 
3.2.2 Sino-British Conventions on Tibet in the Nineteenth Century.....................................56

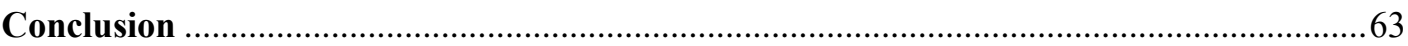

Chapter 4 The Status of Tibet Under the 'Great Game' ................................................65

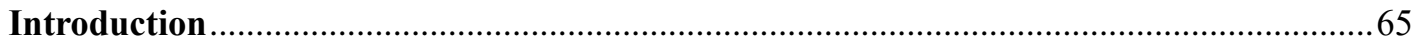

4.1 The British Invasion of Tibet and the Lhasa Convention ...........................................6

4.1.1 Russian Factor in the British Expedition to Tibet ..............................................6 67

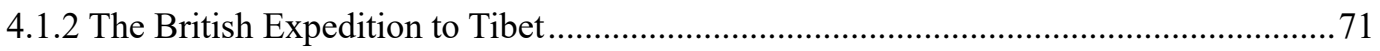

4.1.3 The Conclusion of the Lhasa Convention ................................................................ 75

4.1.4 The Influence of the Lhasa Convention on Shaping Tibet's Status..............................78

4.1.4.1 Was Tibet an Independent State?........................................................................ 78

4.1.4.2 Was Tibet a State Under British Protection?......................................................... 81

4.1.4.3 Tibet as the British Sphere of Influence............................................................... 83

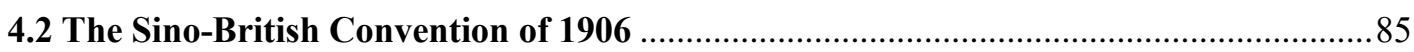

4.2.1 The Sino-British Convention of 1906 in Shaping the Qing's Authority in Tibet ...........86

4.2.2 The Relationship Between the Convention of 1906 and the Lhasa Convention of 1904

4.3 The Anglo-Russian Convention of 1907

4.3.1 The Content of the 1907 Anglo-Russian Convention and its Effects on the Sino-Tibetan

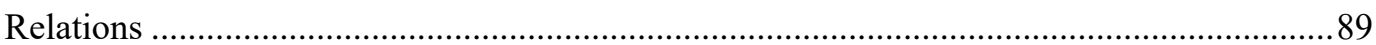

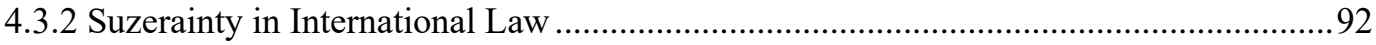

4.3.3 The Dispute on the Status of Tibet between China and Britain-Sovereignty or

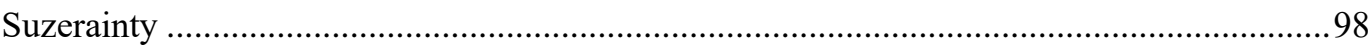

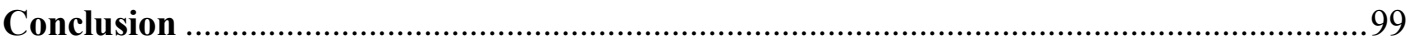

Chapter 5 The Position of Tibet During the Early Period of the Republic of China ............ 102

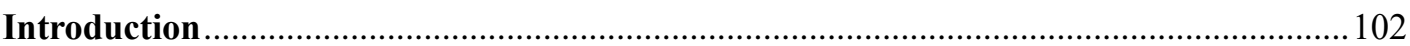

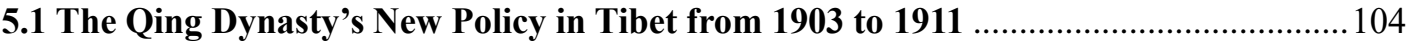

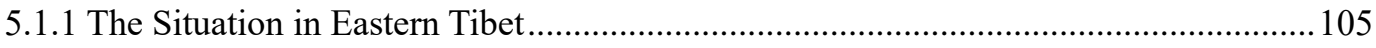

5.1.2 Chang Yin-tang's New Policy in Lhasa .............................................................. 107

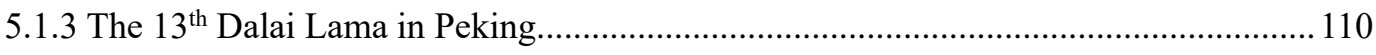

5.2 The Xinhai Revolution and De Facto Independence of Tibet .................................. 113

5.2.1 The Validity of the Mongolia-Tibetan Treaty......................................................... 114

5.2.2 An Analysis of the Dalai Lama's Proclamation of 1913 ........................................120

5.2.3 Tibet and the Status of the De Facto State ........................................................... 123

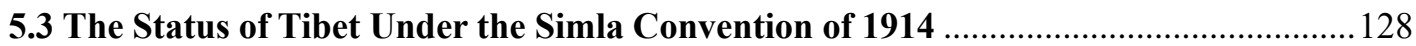

5.3.1 The Formation of the Simla Convention ....................................................... 129

5.3.2 The Effects of the Simla Convention on the Status of Tibet .....................................131

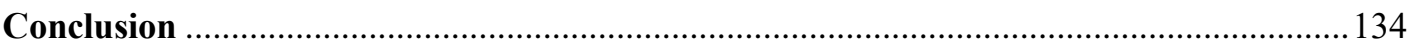

Chapter 6 The Legal Nature of the Dalai Lama's Regime from the Perspective of SinoTibetan Conflicts. 
6.1 Sino-Tibetan Wars and the Nature of the Dalai Lama's Regime in International Law

138

6.1.1 The Concept of a Belligerent and its Legal Personality ............................................ 138

6.1.2 The Criteria of a Belligerent Community............................................................... 141

6.1.3 The Nature of the Dalai Lama's Regime Under the Criteria of a Belligerent ............. 145

6.1.3.1 The Establishment of Sikang Province............................................................... 145

6.1.3.2 Sino-Tibetan Armed Conflicts and Behaviours of Hostile Parties ........................ 148

6.1.3.3 The Territory of the Dalai Lama's Regime .......................................................... 158

6.1.3.4 The Dalai Lama's Regime as a De facto Civil Government................................... 159

6.1.3.5 The Political Pursuit of the Dalai Lama's Regime................................................ 161

6.2 The Legal Nature of the Dalai Lama's Regime from the Perspective of Recognition of

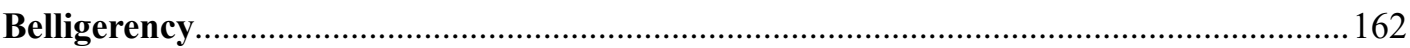

6.2.1 The Nature of the Recognition of Belligerency and the Way it is Made.................... 162

6.2.2 The Legal Nature of the Dalai Lama's Regime from the Perspective of Recognition of

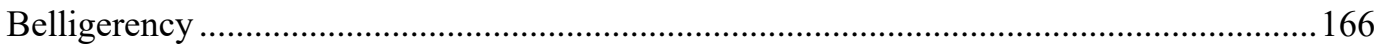

6.2.2.1 The Position of the Chinese Government .......................................................... 166

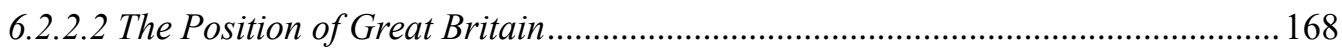

6.2.2.3 The Position of the United States .................................................................... 170

6.2.2.4 The Position of Member States in the UN General Assembly Regarding the Battle

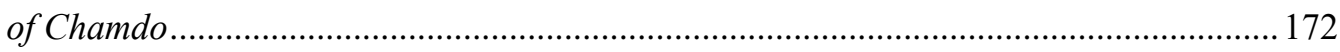

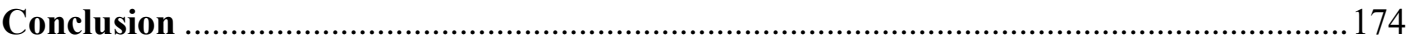

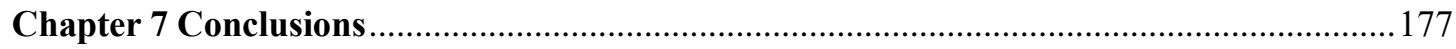

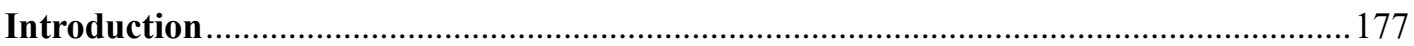

7.1 Key Findings of the Research and Answers to the Research Question ...................... 178

7.1.1 The Status of Tibet Under the Framework of the Tribute System............................. 178

7.1.2 The Status of Tibet at the End of the Nineteenth Century .......................................... 184

7.1.3 The Status of Tibet Before the 1911 Chinese Revolution ......................................... 186

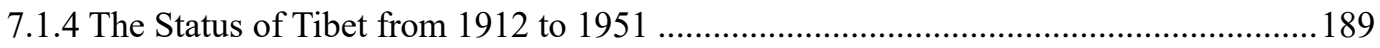

7.2 The Relevance of this Study and Possible Future Research Areas ............................ 193

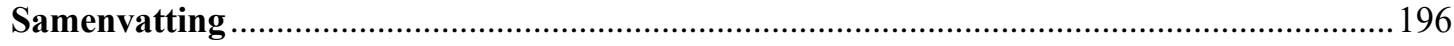

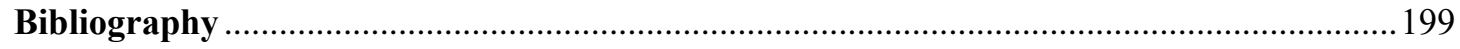

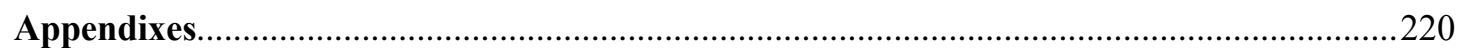

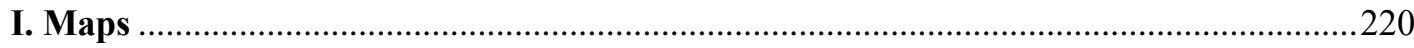

II. Tibet-Related Legal Documents.................................................................... 228

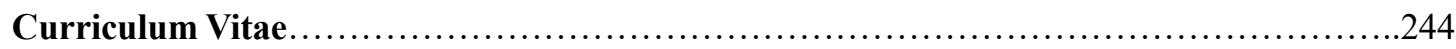





\section{List of Abbreviations}

\begin{tabular}{|l|l|}
\hline American Journal of International Law & AJIL \\
\hline Archives from the British Foreign Office & FO \\
\hline Archives from the India Office Records & IOR \\
\hline British Yearbook of International Law & BYIL \\
\hline Chinese Communist Party & CCP \\
\hline General Assembly & GA \\
\hline Government of India & GOI \\
\hline International Court of Justice & ICJ \\
\hline International Law Commission & ILC \\
\hline People's Liberation Army & PLA \\
\hline People's Republic of China & PRC \\
\hline Permanent Court of International Justice & PCIJ \\
\hline Republic of China & ROC \\
\hline Sino-Tibetan Relation & STR \\
\hline The Union of Soviet Socialist Republics & USSR \\
\hline The United State of American & USA \\
\hline $\begin{array}{l}\text { The Vienna Convention on the Law of } \\
\text { Treaties }\end{array}$ & VCLT \\
\hline Tibet Autonomous Region & TAR \\
\hline
\end{tabular}





\section{Chapter 1 Introduction}

\subsection{Background and Research Question}

The dispute between the Chinese Government and the present Tibetan Government in Exile over the legal status of Tibet has lasted for more than a century, and this divergence has led to many other confrontations between the two sides. For example, in regard to the Chinese taking military control over Tibet in 1951, the Tibetan Government at that time asserted that the Chinese had violated the legal principles governing the use of force as Tibet was an independent State in international society. However, the Government of the People's Republic of China (PRC) claimed that China's action in regaining control of Tibet was entirely in accordance with international law because Tibet has never been an independent State but a Chinese territory.

In fact, the above legal dispute derives from the different historical views on the status of Tibet adopted by the above parties. According to the Chinese Government, Tibet has been under the sovereignty of China since the thirteenth century in the Yuan Dynasty. By appointing imperial residents to manage Tibetan affairs directly, the Chinese control over Tibet had reached its peak during the Qing Dynasty in the late eighteenth century. Based on the theory of the succession of Government, all subsequent Chinese governments have succeeded from the Yuan Dynasty in exercising de jure sovereignty over Tibet, and the PRC has inherited the sovereignty of the Republic of China (ROC) over Tibet. ${ }^{1}$ In contrast, the Tibetan Government in Exile claims that Tibet had always been an independent State, although it also kept a close relationship with China until 1951 when the Chinese force illegally invaded Tibet. They believe that the independence of Tibet had been demonstrated perfectly from 1912 to 1951. During this period, the Tibetans not only expelled the officials and soldiers of the former Qing Dynasty but also steadily controlled all of Tibet's affairs without interference from the Government of the ROC that was established in 1912. Moreover, the Tibetan Government developed relations with some Western States independently and signed some treaties with Great Britain during this time. It can be seen from the perspective of

\footnotetext{
${ }^{1}$ See the Sovereignty over Tibet (西藏的主权归属), in the Website of Chinese Embassy in the UK, 2008, https://www.fmprc.gov.cn/ce/ceuk/chn/zyxw/t419854.htm.
} 
the Tibetan Government in Exile that, leaving aside the complicated relationship between the lamas and Chinese emperors in history, Tibet had become an independent State at least during the period of the ROC, particularly considering that this relationship had no longer existed since the 1911 Chinese Revolution. In order to understand these conceptual differences between the two sides, it is necessary to explore the status of Tibet appropriately.

Due to the complexity of the issue, which intertwined many fields such as history, law and international relations, it is not enough to study this subject from a legal perspective alone without an understanding of the historical context in that region from different times. Therefore, an interdisciplinary approach that combines international legal theories and political history related to Tibet is applied throughout the process of the study. This thesis will answer the following main question: How to understand the legal status of Tibet from the late Qing Dynasty since the 1840s to the restoration of Tibet by the Chinese in 1951? Considering that modern international law was only introduced to China after the Sino-British Opium War in 1840, this thesis adopted the 1840s as the start point of research because China's acceptance and application of international law provided a legal dimension for analysing the Sino-Tibetan relations. And because Tibet has been under the rule of the People's Republic Government since 1951, the thesis chooses this year as the end point of the study.

Before answering the main question, one should bear in mind that everything evolves from its past and the status of Tibet is no exception. The legal status of Tibet during this period was undoubtedly inherited from those of the past in Sino-Tibetan history. From this point of view, a general understanding of the evolution of Tibet's status prior to the 1840 s constitutes a prerequisite for the study of this subject. Therefore, the first subquestion is: What status did Tibet have in the Chinese imperial age from the seventh century to the first half of the nineteenth century? It mainly involves the development of Tibet's status in early Sino-Tibetan intercourses that had taken place under the traditional Chinese tribute system - a set of rules and diplomatic norms grounded in a Confucian ideology that placed China at the apex of this hierarchical world order in dealing with its surrounding countries in East Asia. ${ }^{2}$

\footnotetext{
${ }^{2}$ J. K. Fairbank, 'A Preliminary Framework' in The Chinese World Order: Traditional China's Foreign Relations, Harvard University Press, 1968, p108.
} 
When the Chinese tribute system began to collapse following the encroachment of Western Powers in the 1840s, the last Chinese imperial dynasty - the Qing Dynasty was compelled to embrace the international legal system by making a series of unequal treaties with Western Powers. ${ }^{3}$ In the meantime, the legal status of Tibet was first brought into question by Western Powers. Against the background of the 'Great Game', Britain played a key role in using suzerainty to describe the Chinese influence in Tibet. Given that suzerainty is a concept that has great ambiguity in international law, ${ }^{4}$ the use of this term enabled the British to intervene in Tibetan affairs in their relations with China. At the same time, by recognising the Chinese suzerainty over Tibet, the British also secured the frontier of India by restraining Russia's ambition for Tibet. However, this ambiguous term also to some extent made the status of Tibet unclear. For this reason, the second subquestion refers to how to understand the development of Tibet's status from the Opium War in 1840 to the collapse of the Qing Dynasty in 1911. As China had already adopted international law as the basis for dealing with its foreign relations at this stage, the relevant Tibet-related treaties concluded between China and the third Powers during this period constituted a wealth of legal materials for analysing Tibet's status within the framework of international law. This subquestion will first answer how the Tibet-related treaties reflected Tibet's status and then explores whether 'suzerainty' was an appropriate term to define the Sino-Tibetan relations before the collapse of the Qing Dynasty in 1911.

After the collapse of the Qing Dynasty in 1911, the situation in Tibet underwent a radical change after the Tibetans expelled all the Chinese officials and soldiers from Tibet. For the first time in hundreds of years, the Tibetan Government had got rid of Chinese influence and consistently ruled Tibetan affairs without the interference of the Government of the ROC. In the meantime, the Tibetans maintained contact with some Western States and independently concluded treaties with Great Britain. Based on this, the Tibetan Government in Exile argues that Tibet was an independent sovereign State throughout the ROC. Correspondingly, the third subquestion refers to what status Tibet possessed from the establishment of the ROC in 1912 to the restoration of Tibet by the Chinese in 1951. It involves asking whether Tibet met the criteria of a sovereign State

\footnotetext{
${ }^{3}$ Simon Chesterman, Hisashi Owada, and Ben Saul, The Oxford Handbook of International Law in Asia and the Pacific, Oxford University Press, 2019, pp 20-2.

${ }^{4}$ L. Oppenheim, International Law: A Treaties, Vol.1, London: Longmans, Greens and Co., 1905, p 134; W. Kelke, Feudal Suzerains and Modern Suzerainty, Law Quarterly Review, Vol. 12, Issue 3, 1896, p 223; James Crawford, the Creation of States in International Law, Oxford: Clarendon Press, 1979, p. 209; Alexandrowicz Alexander, The Legal Position of Tibet, the American Journal of International Law 1954, Vol. 48, No. 2, p 266.
} 
in international law, and if not, could it possess any other status from the perspective of international law? In addition, apart from emphasising the legal status of Tibet, is it possible that the supreme authority in this land, namely the Dalai Lama's regime, enjoyed some status in international law in the context of the Sino-Tibetan armed conflicts during this period? Although this work may not directly answer the third subquestion, it will still deepen the understanding of the legal status of Tibet during this period.

This research aims to clarify the legal status of Tibet from the complicated Sino-Tibetan relations in history. And compared with most of the current historical-oriented works on this issue, this study is an interdisciplinary one that combines Tibetan political history and international legal discourse. Thus it provides a relatively new perspective to explain the events in Sino-Tibetan history. To avoid mechanically using the Western international legal term to describe the Sino-Tibetan relations before it was first introduced to China, the thesis innovatively brings the early Sino-Tibetan relations before the 1840s into the orbit of the tribute system. By comparing the similarities and differences on certain issues (for example, territory and effective control) between the tribute system and the Western international legal system, one may obtain a more objective view on the relationship between imperial China and Tibet at its early stage. In the meantime, this thesis has no intention of exploring the whole history between the Chinese and Tibetans in depth, so it focuses more on studying the status of Tibet in the most controversial period, which was from the 1840 s to the $1950 \mathrm{~s}$. The output of this thesis is not only limited to describing the legal status of Tibet during this period but also explores the status of the Dalai Lama's regime during the Chinese Republican era. For those interested in studying Sino-Tibetan relations after 1951, this thesis may also serve as the possible basis for their future work. With regard to the social relevance, since Tibet's status continues to be the core dispute between the Chinese Government and the Tibetan Government in Exile, this thesis may provide new legal insights into this issue, which has the potential to narrow the divergence between them and produce a positive inspiration for any possible negotiation in the future to ultimately resolve the Tibet issue.

\subsection{The Literature Review}


For a long time, the legal status of Tibet has been the focus of neither international legal study nor the study of Tibetology. C. H. Alexandrowicz-Alexander's The Legal Position of Tibet may be the first work to discuss this issue. ${ }^{5}$ By analysing the definition of suzerainty and protectorate in international law, he argued against the PRC's claim to Tibet. According to him, the Chinese suzerainty over Tibet did not become a fact until the second decade of the eighteenth century, then this suzerainty became nominal with the decline of the influence of the Qing Dynasty in Tibet in the second half of the nineteenth century. When the ROC was established in the early 1910s, the Chinese lordship over Tibet had been reduced to a nominal title and Tibet had begun its initial stages of independence. This argument was also adopted by Alfred Rubin in his The Position of Tibet in International Law. Although he considered Tibet to be part of the territory of China before 1912, he generally took an ambiguous attitude toward the status of Tibet during the first half of the twentieth century by analysing the unclear stand of third States on this question. Meanwhile, he admitted that the Chinese military control over Tibet in 1950 may be classified as a breach of international law. ${ }^{6}$ Although the above works attempted to analyse the status of Tibet from the perspective of international law, given that both of them are relatively short, it is impossible to provide readers with sufficient historical facts and detailed arguments. In contrast, Li Tieh Tseng presented a very detailed discussion in his work The Historical Status of Tibet. Through citing a wide range of documentary evidence, he analysed the status of Tibet in different periods and concluded that Tibet had become a buffer State since the Western encroachment in the latter part of the nineteenth century. ${ }^{7}$ But given that the concept of a buffer State places more emphasis on the function of the mentioned subject rather than its legal status, in this sense, Li adopted an international politics-based approach to this issue rather than international legal discourse.

Another work on the status of Tibet is Michael van Praag's The Status of Tibet, which examines the legal history of the Sino-Tibetan conflict. ${ }^{8}$ This study argues that Tibet must be viewed as an independent State throughout its history in various aspects of international law, including Statehood, independence, protectorate, suzerainty, acquisition of territory, annexation and self-determination. ${ }^{9}$ Although he noticed the

\footnotetext{
${ }^{5}$ Alexandrowicz Alexander, ibid.

${ }^{6}$ Alfred Rubin, The Position of Tibet in International Law, The China Quarterly, Volume 35, 1968 , pp. 110-154.

${ }^{7}$ Li Tieh-Tseng, The Legal Position of Tibet, The American Journal of International Law, Vol. 50, No. 2 (Apr., 1956), pp 394-404.

${ }^{8}$ Michael. van Praag, The status of Tibet: history, rights, and prospects in international law, Westview Press, 1987.

${ }^{9}$ Ibid, pp 93-110; 133-41; 102-4; 127-29; 104-7; 177-88; 183-88; 189-97.
} 
incompatibility of using suzerainty to describe the traditional Sino-Tibetan relations, his view on the chö-yön (priest-patron) relationship, which he saw as a personal and religious relationship between the Chinese emperor and the Tibetan lama, may not fully reflect political reality in Sino-Tibetan history because political affiliations often take on the cloak of a religious relationship in the pre-modern world. With regard to the role of the British in shaping Sino-Tibetan relations, the work of Amy Kellam, Law's Imperial Discourse and the Status of Tibet, examines how the British imperial legacy in the region converged with Chinese formulations of law and governance in Tibet to prejudice understanding of Tibet's legal status. She concluded that by the turn of the twentieth century, Tibet was neither independent nor part of the Russian, British or Chinese empires that sought to control Tibet's status as part of their own frontier defence strategies. ${ }^{10}$ However, she did not explicitly mention which status Tibet had on earth if it was not an independent State. Although the above-mentioned works tried to discover the status of Tibet in history, their flaws are also obvious because they either did not answer this question from the perspective of international law or they did not explain many historical events regarding Tibet by applying the theories of international law in an accurate and unambiguous way. Furthermore, another main flaw in most of the above works may lie in putting too much weight on the relevance of English sources while neglecting the importance of the Chinese sources in explaining the status of Tibet. In order to overcome the above flaws, this research will only focus on issues related to Tibet's status in an international legal-oriented perspective. In the meantime, to obtain a comprehensive understanding of historical materials regarding Tibet, this research not only utilises many English archives and literature but also attaches importance to a large number of Chinese materials to avoid overreliance on the sole-language source.

\subsection{Research Methods}

As an interdisciplinary study exploring the status of Tibet, this thesis combines SinoTibetan history and international legal discourse. Consequently, the historical method of international law is utilised throughout the research. The historical method involves exploring the developments and practice of international law from a time dimension, concentrating on specific historical events recorded within documentary evidence.

\footnotetext{
${ }^{10}$ Amy Kellam, Foreign Devils: Law's Imperial Discourse and the Status of Tibet, the $\mathrm{PhD}$ thesis submitted for the Department of Law, SOAS, University of London, 2013.
} 
Because the Sino-Tibetan relations were not static, and they had their characteristics in different periods, the historical method is an ideal way to conduct the research.

Specifically speaking, in order to make research more logical and organized, legal historians usually divide their research into different parts defined by different periods, which is called 'periodization'. Usually, periodization is understood as the 'process or study of categorizing the past into discrete quantified named blocks of time in order to facilitate the study and analysis of history'. ${ }^{11}$ As a typical thought pattern, the division of historical events into different periods is indispensable for international legal history research. Historical facts cannot be identified without referring to a time frame with a more or less determinable beginning and end, and periods make historical facts 'thinkable'. ${ }^{12}$ Based on imperial power, Western universalism and the sovereign State, periodization in international legal history can be classified into three main types, which are not mutually exclusive and can be combined into a single narrative, according to Randall Lesaffer. They are the 'hegemonic approach', the 'Eurocentric approach' and the 'State-centric type of periodization'. ${ }^{13}$ The hegemonic approach was proposed by Wilhelm Grewe, and he divided the history of international law into epochs characterized by the dominance of particular hegemonic powers. According to Grewe's understanding of the evolution of major power structures, the history of international law should be divided into the Spanish age (1494-1648), the French Age (1648-1815), the British Age (1815-1919), the Age of the Anglo-American condominium (1919-44) and the Age of American-Soviet rivalry (1945-89). ${ }^{14}$ As well as this hegemonic approach, Heinhard Steiger put forward a Eurocentric approach that divided the history of international law into the 'Age of Christianity' (from 1300 to 1800), the 'Age of the Civilised Nations' (from the nineteenth century to 1918) and the 'Age of Mankind' (since 1919). ${ }^{15}$ From this perspective, the Western political model has inevitably stood for the evolving path of the international legal order. With regard to the State-centric approach to periodization, the first stage in the classical periodization of international

\footnotetext{
${ }^{11}$ Adam Rabinowitz, 'It's About Time: Historical Periodization and Linked Ancient World Data,' Institute for the Study of the Ancient World Papers 7 (2014): p 20.

${ }^{12}$ Oliver Diggelmann, the periodization of the history of international law, the oxford handbook of history of international law, the oxford university press, 2012, pp 997-1011.

${ }^{13}$ Randall Lesaffer, The End of the Cold War: An Epochal Event in the History of International Law? Tilburg Working Paper Series on Jurisprudence and Legal History, No. 10, 2010, p 1; 5.

${ }^{14}$ Wilhelm Grewe, The Epochs of International Law, Berlin: De Gruyter, 2000, pp 1-6. Recite from Ignacio de la Rasilla, The Problem of Periodization in the History of International Law, Law and History Review, Vol. 37, No. 1, 2019, p 279.

${ }^{15}$ Ibid, Heinhard Steiger, From the International Law of Christianity to the International Law of the World CitizenReflections on the Formation of the Epochs of the History of International Law, Journal of the History of International Law Vol. 3, 2001, pp 180-93.
} 
law is often identified as the date of the Peace of Westphalia, as it was a starting point of the principles of equal sovereignty of European States in both their internal and external relations. ${ }^{16}$ This State-centric approach is in essence a Eurocentric division method and has naturally been contested as a starting point for the history of international law by other international lawyers. The opinion regarding the principle of sovereign equality as the beginning of the international legal history may be correct for Europe itself, but merely false for non-European States. For many non-European States, the origins of international law may be found in empires. ${ }^{17}$ With regard to the study of Tibet's status, given that China had long played a non-European hegemonic role in East Asia, the thesis first adopts a hegemonic approach of periodization that divides the research period into two main periods. One is the period of Chinese hegemony in SinoTibetan relations, and the other is the period of Western hegemony in Sino-Tibetan relations.

The first period involves Sino-Tibetan relations before the 1840s. Considering that the Western international law was not introduced to China until the encroachment of Western imperialism in the 1840s, the mechanical application of Western international law to explain the Sino-Tibetan intercourse will inevitably lead to the misinterpretation of some specific events due to the disjunction between the traditional Chinese world order and the European one. Instead, the author uses the regionalism approach to explain the Sino-Tibetan relations before this period. International legal history can be local, focusing on the domestic or regional track of international legal history. Although international legal history for a long time has adopted a Eurocentric focus, the local or regionalism approaches aim to overcome the traditional Eurocentrism of the history of international law. ${ }^{18}$ The regionalism approach highlights the fact that non-European developments of international law are excluded from the consideration of many traditional histories of international law. A truly 'universal' history of international law would seek to include the forms of regional international law that emerged in ancient China or ancient South Asia. ${ }^{19}$ It should be admitted that particular regions developed a set of rules or practices that enabled the various entities that were members of that

\footnotetext{
${ }^{16}$ Ignacio de la Rasilla, History of International Law, 1550-1700, Oxford Bibliographies of International Law, 2018, https://www.oxfordbibliographies.com/view/document/obo-9780199796953/obo-9780199796953-0036.xml.

${ }^{17}$ Lauren Benton and Lisa Ford, Rage for Order: The British Empire and the Origins of International Law, 18001850, Harvard University Press, 2016.

${ }^{18}$ Valentina Vadi, International Law and Its Histories: Methodological Risks and Opportunities, Harvard international law journal, Vol. 58, No. 2, 2017, pp 327-28.

${ }^{19} \mathrm{~W}$ Preiser 'History of the law of nations: basic questions and principles' in R Bernhardt Encyclopedia of public international law (2nd edn Elsevier North-Holland 1995), vol 2, at 127.
} 
regional grouping to interact with each other. ${ }^{20}$ For example, Nagendra Singh finds in Indian law precursors to much of modern international law. He aims to show the consistency between ancient Indian international law and contemporary international law, and thus uses modern terms to describe similar Indian practices to emphasize the similarity of the two legal systems. ${ }^{21}$ In the case of China, instead of developing a Westphalian world order based on the conception of sovereignty and the equality of States, imperial China adopted a hierarchical and Sinocentric system that embodied a set of rules and diplomatic norms to deal with its surrounding countries, and this system is called the 'tribute system'. ${ }^{22}$ As a form of administrative management for imperial China's external relations, the tribute system contained many aspects, from trade relations to the administration of empire frontiers. Because the boundaries between territories of the Chinese imperial court and surrounding countries were far from clear and were always in a dynamic state according to different periods, the Chinese emperor was inclined to adopt a set of different ruling techniques to the vast frontier area, which is called Fanbu (藩部) under the tribute system. ${ }^{23}$ Usually, these ruling strategies in Fanbu were distinctive from those of the interior because the Chinese emperor was inclined to exert his influence there indirectly and to grant different degrees of autonomy to local chieftains in different cases. Although the regionalism approach provides a more appropriate perspective for exploring the status of Tibet by bringing the early Sino-Tibetan relations into the framework of the tribute system, it does not necessarily preclude the idea of contemporary international law from analysing the traditional Sino-Tibetan relations because there must be some similarities between the ancient Chinese tribute system and contemporary international law in certain fields. For example, on the question of territory, whether ancient or modern, or in China or the West, effective control is always the key element in determining the ownership (or sovereignty in a modern sense) of a certain portion of land.

The second period involves the Sino-Tibetan relations from the 1840 s to 1951. As mentioned above, the acceptance of Western international law by China against Western encroachment made it possible to understand the significance of China's behaviour

\footnotetext{
${ }^{20}$ Antony Anghie, Identifying regions in the history of international law, the oxford handbook of history of international law, the oxford university press, 2012, pp $1058-1078$.

${ }^{21}$ Nagendra Singh, India and International Law Part A: Ancient and Mediaeval, S Chand, 1969. Recite from Carl Landauer, Regionalism, Geography, and the International Legal Imagination, Chicago Journal of International Law, Vol. 11: No. 2, 2011, p 567.

${ }^{22}$ Phil C.W. Chan, China, State Sovereignty and International Legal Order, Brill, 2015, pp 66-71.

${ }^{23}$ Shin Kawashama, China, Chapter 19 in the oxford handbook of history of international law, the oxford university press, 2012, pp 453-455.
} 
from the perspective of modern international law. For the convenience of research, this period is divided into two subperiods. One focuses on exploring the development of Tibet's status from the 1840 s to 1911 , the other concentrates on examining whether Tibet had become an independent sovereign State from 1912 to 1951, and if not, what status it had in international law. In this part, an analytical method is utilized to explain the legal status of Tibet during this period. The analytical method involves using facts or information already available and analysing these to make a critical evaluation of the material. In order to collect the Tibet-related information needed for this thesis, the author visited many libraries and archives, including the British Library, the British National Archives, the National Library of China, the Second Historical Archives of China and the Archives of Tibet Autonomous Region. Consequently, a variety of primary and secondary sources is utilised in this study. Primary historical sources are archives of the British Government that cover the period of British influence in Tibet, which provide us with an opportunity to observe the frequently divergent views of the Foreign Office and the British Government of India on Tibet. They not only include official correspondence and reports but also personal diaries and letters from the British officers. Apart from the English sources, the Chinese archives also constitute an important primary source as they reflected China's attitude towards Tibet during the different periods and its endeavour against the imperialist threat throughout the nineteenth and twentieth centuries. Other documents that can be considered primary sources are treaties between Tibet, China, Britain, Russia and Mongolia. In addition, the secondary source material used for this study mainly consists of works by Tibetologists, books and articles by international law scholars, legal cases and international legal documents.

\subsection{Limitations}

The time scope of this thesis mainly focuses on the period from the $1840 \mathrm{~s}$ to the $1950 \mathrm{~s}$. As mentioned earlier, the deepest dispute between the Government of the PRC and the Tibetan Government in Exile is the status of Tibet during this period. For this reason, using relevant international law theory to explain the Sino-Tibetan intercourses since the 1840 s naturally constitutes the core content of this study. At the same time, the necessity of a brief review of Tibet's status prior to this period within the framework of the tribute system should also not be looked down upon as it provides crucial contextual 
information on Tibet's status after the 1840s. Moreover, with regard to materials, the sources used in this study are limited to English and Chinese materials, and the limitation arises as the author lacks the capacity to deal with Tibetan materials. Nevertheless, there still exist some Tibetan works in translation that are invaluable for understanding how Tibetans regarded their nation and their relationship with China in the long historical process.

\subsection{Structure of the Study}

As an interdisciplinary study, this thesis focuses on the legal and historical aspects of Sino-Tibet relations from the 1840 s to the 1950s. Albeit relying on a wide range of academic fields, international law remains the core pillar of this research. Following a chronological overview of events, an exploration of these events from the perspective of international law was carried out throughout the periods under discussion.

There are seven chapters in this thesis. Following the introductory chapter, Chapter 2 presents a general understanding of the early Sino-Tibetan relations under the framework of the tribute system. This chapter focuses on exploring the Sino-Tibetan relations from the Tang Dynasty to the mid-Qing Dynasty to illustrate the development of Tibet's status from an independent empire to an outer tributary and eventually to an inner tributary under the sovereignty of the Qing in the eighteenth century.

After the discussion on the Sino-Tibetan relations in the traditional Chinese tribute system, the rest of the chapter focuses on exploring the legal status of Tibet under the framework of contemporary international law. Chapter 3 discusses the early British policy towards Tibet as well as its attitude on Sino-Tibetan relations. In order to achieve this, China's approaches to international law and the validity of the unequal treaty are first discussed in the third chapter. After that, the attention shifts to the first contact between the British India Company and the Panchen Lama as well as the role the British played in the Gurkha-Tibetan war from 1788 to 1792 . At the end, three early Tibetrelated treaties between China and Great Britain in the second half of the nineteenth century are analysed to clarify the British attitude towards the status of Tibet in relation to China. 
Chapter 4 explores the change of British policy towards Tibet. A key event was the British invasion of Tibet in 1903, which directly marked this change of policy. As a consequence of the British invasion, the Lhasa Convention of 1904 is examined to illustrate the British position on relations with Tibet at that time. Then the rest of the chapter discusses how the British consolidated their advantages in Tibet by concluding a series of treaties with China and Russia in the early twentieth century as well as their impact on the status of Tibet in the early twentieth century.

Chapter 5 explores the status of Tibet during the early period of the ROC. Compared with Chapter 6, which focuses on the armed conflicts between the Chinese and the Tibetans from 1912 to 1951, this chapter focuses more on the peaceful aspects of the Sino-Tibetan interactions during the Republican era. By analysing the legal effects and the validity of the treaty between Mongolia and Tibet of 1913 and the proclamation issued by the 13th Dalai Lama in the same year, the chapter first explains why Tibet was not an independent State from the perspective of international law. Based on this, the rest of the chapter compares the characteristics of Tibet with the concept of de facto State and then argues that Tibet should be considered a de facto State in international law from 1912 to 1951 . Moreover, the last section of the chapter also examines the status of Tibet under the Simla Convention between the Chinese, the British and the Tibetans in 1914.

Apart from focusing on the Statehood of Tibet, Chapter 6 explores the possibility that the Dalai Lama's regime, as the supreme authority of Tibet that formed the core element of a de facto State, could possess any status in international law against the background of the Sino-Tibetan armed conflicts from 1912 to 1951. As a temporal and limited subject of international law regarding civil wars, the concept of belligerent and its recognition is introduced in this chapter to consider whether the Dalai Lama's regime could be regarded as a belligerent community from the perspective of non-international armed conflicts. These efforts, in return, may deepen the understanding of Tibet's status as a de facto State because the criteria of de facto States substantially overlap with those of belligerents when there exists a civil war aimed at secession within a State, although the former focuses more on the status of the State-like entity ruled by an organized political leadership, while the latter emphasises more the status of such an organization in regard to wars. 
Chapter 7 presents an overall conclusion. 


\section{Chapter 2 The Early Relations Between Imperial China and Tibet under the Tribute System}

\section{Introduction}

According to Buddhist cosmology, the mahakalpa is used to describe the four periods of time which correspond with the four stages that a world is said to undergo: formation, existence, destruction and emptiness. ${ }^{1}$ Since everything in the universe has its own past, present and future, the question of Tibet's status is naturally no exception to this law of nature. Although the core aim of this thesis is to clarify the status of Tibet in international law from the 1840 s to the 1950 s, Tibet's past is by no means irrelevant to this aim, as its status in these particular years was inherited from its previous status, especially from the early Sino-Tibetan interactions. Therefore, understanding the development of Tibet's status in its early stages becomes a prerequisite to an exploration of its status since the second half of the nineteenth century. Due to its special history and culture, ancient China did not build a diplomatic system based on the principle of sovereign equality. It was not until the Opium War (1839-1842) that China was forced to learn about modern international relations and to accept international law, a European norm of a new international relationship. In this sense, international law, which emerged in Europe at the end of the seventeenth century, is probably not an ideal theoretical tool to explain what happened in a different cultural background before it came into being. For this reason, a theoretical framework that can serve as international law should be built to explore the status of Tibet in the early Sino-Tibetan interactions. In order to handle the relations with the surrounding ethnic minorities and countries, ancient China had developed a set of rules and practices called the tribute system to carry out its foreign policy for more than one thousand years. With regard to the case of Tibet, the tribute system provides a theoretical perspective to explain the development of Tibet's status in the early Sino-Tibetan interactions.

\footnotetext{
${ }^{1}$ See Dīrgha Āgama, the English translation can be seen in Shohei Ichimura, the Canonical Book of the Buddha's Lengthy Discourses, Vol. III, BDK America, 2018, p 250.
} 
This chapter begins with a discussion on the content of the tribute system, which involves its theoretical foundation and practices in ancient China's foreign relations. After understanding the discrepancy between theory and practice in the tribute system, the second section of the chapter explores the development of Tibet's status in different periods by bringing the early Sino-Tibetan interactions into this system. In order to explain how Tibet changed from an independent empire to a vassal and finally to a part of China, this section reviews the interactions between imperial China and Tibet from the Tang Dynasty (618-907 AD) and the Yuan Dynasty (1271-1368 AD) to the middle of the Qing Dynasty (1644-1840 AD). Since the tribute system is a regional order of ancient East Asia which is fundamentally different from the Western international legal order, a regionalism approach is used to discuss the contribution of the tribute system to the regional order in ancient East Asia if the history of international law should not overemphasise the centrality of western contexts of practice and underemphasize the practice of international law outside the West. ${ }^{2}$ With regard to the sources of this chapter, the tribute system produced a wide range of diplomatic norms and institutions that were similar to today's international customs, and this chapter introduces the four basic institutions: Cefeng (confer titles), Hushi (mutual trade), Huimeng (the meeting for alliance) and Heqin (marriage alliance) as primary sources. The books and historical literature that reflect the operation of the tribute system and the development of SinoTibetan interactions serve as secondary sources.

\subsection{The Chinese World Order-the Tribute System}

International law, defined as the rules governing relations between sovereign states, used to be considered a product of the European civilization that formed in the early seventeenth century. Correspondently, the history of international law has thus been deeply Eurocentric as 'Europe served as the origin, engine, and telos of historical knowledge'. ${ }^{3}$ Nevertheless, this Eurocentric perspective may generate a distortion that overemphasises the western practice of international law and underemphasises the nonwestern one in the historical narrative. The identification of a Eurocentric distortion requires the construction of a non-Eurocentric reading of international law's origin and

\footnotetext{
${ }^{2}$ Arnulf Becker Lorca, Eurocentrism in the History of International Law, in The Oxford Handbook of the History of International Law, Oxford University Press, 2012, p 1035.

${ }^{3}$ Martti Koskenniemi, Histories of International Law: Dealing with Eurocentrism, Rechtsgeschichte, 19, 2011, p 158.
} 
development that diverges from conventional narratives. ${ }^{4}$ International lawyers need to be aware of certain national and regional differences in approaches to international law as it is a legal field that encompasses multiple national traditions. ${ }^{5}$ It is against this background that the contribution made by non-European civilizations to the regional order has increasingly drawn the attention of scholars in the history of international law. ${ }^{6}$ With regard to East Asia, ancient China had developed a hierarchical and Sinocentric ideology that contained a set of rules and institutions to guide its foreign relations, and this ideology and its practice constituted a Chinese world order called the tribute system (Chaogong Tixi; 朝贡体系). In order to obtain a basic knowledge of this system, this section begins with an exploration of the theory of the tribute system as well as its institutions. The discussion then moves to the discrepancy between its theoretical foundation and its practice. The section also focuses on explaining the impact of the tribute system on shaping the Chinese Empire's view of its boundary. This work will be helpful in understanding the development of Tibet's status by applying the standard of how imperial China distinguished its own land from the outside world to the Sino-Tibetan interactions.

\subsubsection{The Concept of the Tribute System}

Ancient Chinese society has traditionally been considered hierarchical, with the emperor at the apex of the pyramid of the society and his subjects constituting the base. Chinese foreign policy, as a reflection of its social structure, was also hierarchic and asymmetric. According to the Chinese traditional geographical idea that the 'heaven is round and the earth square', ${ }^{7}$ China was at the centre of the world (Tianxia), ${ }^{8}$ and its emperor, as the 'son of heaven' who received the mandate of heaven, was the ruler of this world. People who lived outside of the emperor's direct rule were usually considered as uncivilised barbarians. Due to this sense of cultural superiority, the tribute

\footnotetext{
${ }^{4}$ Arnulf Becker Lorca, p 1035.

${ }^{5}$ Anthea Roberts, Is International Law International? Oxford University Press, 2017, pp 1-18.

${ }^{6}$ For example, W. Preiser argued that: "any truly 'universal' history of international law would seek to include the forms of regional international law that emerged in ancient China or ancient South Asia." See History of the law of nations: basic questions and principles' in R Bernhardt's Encyclopedia of public international law (2nd ed Elsevier North-Holland 1995), vol 2, at 127.

${ }^{7}$ Zhao Zhongshu, Round Sky and Square Earth (Tian Yuan Di Fang): Ancient Chinese Geographical Thought and its Influence, History of Geographical Thought, Vol. 26, No. 2, 1992, pp. 149-52.

${ }^{8}$ Tianxia is a Chinese term for an ancient Chinese cultural concept that denoted either the entire geographical world or the metaphysical realm of mortals, and later became associated with political sovereignty. It often referred to the lands, space, and area divinely appointed to the Emperor by universal and well-defined principles of order.
} 
system cannot be a model of inter-State communication based on an equal footing. As a concept, there are three main views on the definition of the tribute system based on different observational dimensions.

The concept of the tribute system was first put forward by Fairbank by the observation of ancient Chinese foreign relations. According to him, the tribute system is 'the medium for Chinese international relations and diplomacy' and the 'mechanism by which barbarous non-Chinese regions were given their place in the all-embracing Chinese political, and therefore ethical, scheme of things'. ${ }^{9}$ Fairbank thinks that the Chinese emperor initiated the tribute system because he valued the prestige that those barbarians would bring to his rule, and foreign rulers participated in the tribute system because they valued the benefits of trading with China. It can be seen from Fairbank's expression that he regards the tribute system as a mutually beneficial mechanism for the Chinese ruler and foreigners because both of them get what they want from this system, albeit with Chinese superiority in their inegalitarian interactions. Apart from Fairbank's view, many Chinese historians prefer to think of the tribute system as China's bureaucratic management of foreign relations which focuses on the organisational and functional development of a complex set of principles, rules, and procedures that China's Confucianists devised to deal with barbarians. ${ }^{10}$ This view regards the tribute system as an integral part of the ancient Chinese bureaucracy for handling its foreign relations, but this bureaucratic view inevitably neglects dynamic characteristics when ancient China dealt with surrounding non-Chinese. The third view, commonly found among international relations scholars, often considers the tribute system as an institution of ancient East Asian international society. For example, Yongjin Zhang argued that 'the tribute system is the fundamental institution that embodies both philosophical assumptions and institutional practices within the Chinese world order and that structures relations and ensures cooperation between China and other participants in Pax Sinica'. ${ }^{11}$ This view takes the theoretical basis of Chinese superiority and specific practices of the tribute system into account; thus it can more accurately reveal the internal and external logic of the tribute system. Traditionally, the

\footnotetext{
${ }^{9}$ J. K. Fairbank and S. Y. Teng, On the Ch'ing Tributary System, Harvard Journal of Asiatic Studies, Vol. 6, 1941, pp. $137,139$.

${ }^{10}$ Li Yunquan (李云泉), Chaogong zhidu shilun: Zhongguo gudai duiwai guanxi tizhi yanjiu (朝贡制度史论-中国 古代对外关系体制研究, A History of the Tribute System: Research on China's Premodern Foreign Relation Institution), Beijing: Xinhua Press (新华出版社), 2004.

${ }^{11}$ Yongjin Zhang, System, Empire and State in Chinese International Relations, in Michael Cox, Empires, Systems and States: Great Transformation in International Politics, Cambridge University Press, 2001, pp. 43-63, at p. 57.
} 
theories of the tribute system tended to emphasise China's superior role and to neglect the dynamic role of non-Chinese in their mutual interactions, which makes it difficult to explain the discrepancy in the tribute system between its theoretical foundation and practices. The following discussion tries to unfold the differences in the ideology of Chinese superiority embedded in the consciousness of ancient Chinese rulers and its exceptions in practice.

As mentioned above, the tribute system was built on the assumption of Chinese superiority and according to this premise, the Chinese emperor should be at the top of this hierarchical system, and his imperial court should dominate the relations with surrounding non-Chinese. However, it is not hard to see from historical evidence that the emperor occasionally submitted to so-called 'barbarians' and paid tribute to them. For example, the emperor of the Han Dynasty (202 BC-220 AD) once temporarily became the subordinate of the chief of the Huns and rendered a large quantity of money to the latter during the early Han Dynasty. ${ }^{12}$ Similarly, the Song Dynasty also served as the fraternal country to the Khitan regime in the north and then became a subordinate of the regime founded by Jurchens. ${ }^{13}$ Does this discrepancy between the theory and the practice indicate that the tribute system was a fanciful order based on an unreliable theoretical foundation? In fact, the existence and change of any regional or international order usually depend on the rise and fall of a country's power in a certain period, ${ }^{14}$ and so it was with the tribute system. When the surrounding non-Chinese were much stronger than the imperial court, the latter had to temporarily give up its cultural superiority and obey the political reality, while the non-Chinese were pleased to accept the tribute system and played a dominant role in their relations with China, especially when they had already been deeply influenced by Chinese culture. In this sense, the inversion of subject and object within the framework of the tribute system does not mean the failure of the system. By contrast, it reveals that the tribute system was a dynamic and flexible mechanism rather than a static one as neither the powerful nonChinese nor the imperial court left the orbit of the system. Once China gained an advantageous position, the imperial court would immediately restore the original appearance of the tribute system based on Chinese superiority. In the following

\footnotetext{
${ }^{12}$ Li Yunquan, p 13.

${ }^{13}$ Ibid.

${ }^{14}$ Betty A Dobratz, Lisa K Waldner, Timothy Buzzell, Power, Politics, and Society: An Introduction to Political Sociology, Pearson, 2011, p 324.
} 
discussion, four basic institutions are introduced to imply rights and duties between the imperial court and surrounding non-Chinese within the framework of the tribute system.

\subsubsection{The Institutions in the Tribute System}

In the long history of the practice of the tribute system, the Chinese imperial court developed a series of institutions and rules that contained rights and duties designed to clarify its relations with the surrounding non-Chinese people. There were four mostly used institutions governing peace and war between the two parties: Cefeng (confer titles; 册封), Hushi (mutual trade; 互市), Huimeng (the meeting for alliance; 会盟) and Heqin (marriage alliance; 和亲).

With regard to the surrounding non-Chinese people, as the object of the tribute system, they were generally divided into two categories based on their degree of political organisation. One was people who accepted the Confucian culture and existed in the form of countries. They lived steadily in a certain territory and formed a political unit with its own government, such as Japan, Korea, and Vietnam. The other was nomadic people who lived in the periphery of imperial China and usually existed in the form of tribes, such as Huns, Jurchens, Khitan, Xianbei and Mongolian. Unlike countries, these tribes were political unit formed from kinship. Seeing that the lifestyle of these nomadic people was centred around livestock, they did not live steadily in a certain territory, nor did they have a unified government. Although they did not accept Confucian culture and kept their own language and religion, they had frequently communicated with China proper through war and trade. When these tribes rose, they would imitate the political structure of imperial China and establish their own country. For example, the Liao Dynasty was founded by the nomadic Khitan tribes that ruled from 916 to 1125 over present-day Northern and Northeast China. ${ }^{15}$ Similarly, the Jin Dynasty was formed by the Jurchens who had previously been the subjects of the Liao, and who ruled northern China from 1115 to $1234 .{ }^{16}$ When these countries were conquered, they usually reverted to being in the form of tribes. With the changes in history, these nomadic people were either integrated into the Chinese Han or still live in China as

\footnotetext{
${ }^{15}$ Gong Ying (龚荫), History of China's ethnic policies, Vol. 3 (中国民族政策史), Yunnan University Press, 2014, pp 645-57.

${ }^{16}$ Ibid, pp 665-74.
} 
ethnic minorities. From a modern point of view, this is the reason the tribes and countries historically established by these nomadic people are usually called ethnic minority regimes.

The institution of Cefeng and Huishi were usually used to regulate the relations between China and the surrounding non-Chinese in peacetime. With regard to Cefeng, this institution refers to the historical phenomenon in which the Chinese emperor acted to confer the authority and symbols of a high office on a foreign ruler. ${ }^{17}$ As mentioned earlier, the core aim of the tribute system is to establish a hierarchical political structure in which the emperor is at the top and deserves the submission of uncivilised people outside his rule. In general, the emperor was not inclined to interfere with these people or bring them into his own jurisdiction if they did not threaten the peace. When the ruler of tribes and surrounding countries showed the will of submission to the emperor, the latter would gladly receive this good-will as it manifested that the emperor's wisdom and virtue had been perceived by the distant people. In this case, the ruler of ethnic tribes and surrounding countries would dispatch representatives to the imperial court and pay tribute (local specialty, treasure, or animal) to the emperor. In return, the emperor usually rewarded the ruler with presents that were much more valuable than the tribute and conferred on the ruler noble titles. In some cases, an imperial seal would be granted to the rulers to manifest the legitimacy of their rule. This set of procedures is called Cefeng. Generally, the completion of Cefeng often signified that a suzerainvassal relationship was established between the imperial court and surrounding ethnic tribes and countries. But the content of this relationship was largely uncertain and usually varied with different cases and different times. Compared with Cefeng, Hushi was usually the main motivation for the surrounding ethnic tribes and countries to admit the superiority of China. In practice, their representatives not only paid tribute to the emperor in exchange for many gifts but also sold their local specialties on the way to the capital for great profits. ${ }^{18}$ In this sense, Hushi is a form of mutual trade under the guise of paying tribute. Although the emperor was not interested in trading with 'uncivilised people', the trade under the pretext of tribute inevitably imposed a huge burden on the imperial finances, so that the imperial court had to limit the frequency of paying tribute in a certain period.

\footnotetext{
${ }^{17}$ Barry Buzan, Yongjin Zhang, Contesting International Society in East Asia, Cambridge University Press, 2014, $p$ 43.

${ }^{18}$ Gakusho Nakajima, The Structure and Transformation of the Ming Tribute Trade System, in Global History and New Polycentric Approaches edited by Manuel Perez GarciaLucio De Sousa, Palgrave Macmillan, 2018, pp 137-62. 
It can be seen from the above discussion that both Cefeng and Hushi were utilised in peacetime to establish and maintain the submission and closeness to the imperial court of the ethnic minority tribes and countries. Through Cefeng and Hushi, the emperor's sense of superiority was satisfied at the expense of recognising the legitimacy of the barbarian regime and carrying the financial burden; and the surrounding ethnic minority tribes and countries gained great profits at the expense of acknowledging the superiority of China.

In comparison with Cefeng and Hushi, Huimeng and Heqin usually happened when the imperial court lacked an absolute advantage over the surrounding power and, therefore, both parties interacted on a relatively equal basis. The institutions of Huimeng and Heqin were aimed at ending conflicts and wars between the imperial court and ethnic minority regimes. Huimeng, which was similar to a peace conference in modern time, was often aimed at declaring the end of a war, demarcating the boundaries and forming a military alliance. ${ }^{19}$ Heqin, as a matrimonial alliance, was often used to reinforce the outcome of Huimeng. It refers to the practice of the Chinese emperor to betroth his daughter to the ruler of an ethnic minority regime, and it was often adopted as an appeasement strategy to deal with the surrounding ethnic regimes that were too strong to defeat on the battlefield. ${ }^{20}$ The institutions of Huimeng and Heqin were obviously not in accordance with the assumption of Chinese superiority; on the contrary, they reflected how the imperial court would respond to the so-called 'barbarians' when the political power had shifted to the latter. It indicated that the tribute system was a highly elastic system which could be reinterpreted for a self-serving purpose. ${ }^{21}$

After explaining these four basic institutions in the tribute system, the next discussion moves to the influence of the tribute system on shaping ancient China's sense of boundary.

\footnotetext{
${ }^{19}$ Sun Jing (孙静), the Study on the Border Security Function of the Huimeng between the Tang Dynasty and Tibet Empire (试论吐蕃与唐会盟的安边功能), Heilongjiang Chronicles (黑龙江史志), Vol. 9, 2014, p 57.

${ }^{20}$ George Qingzhi Zhao, Marriage as Political Strategy and Cultural Expression: Mongolian Royal Marriages from World Empire to Yuan Dynasty, Peter Lang Publishing 2008, pp 32-33.

${ }^{21}$ Yuankang Wang, Explaining the Tribute System: Power, Confucianism, and War in Medieval East Asia, Journal of East Asian Studies 13 (2013), p 213.
} 


\subsubsection{The Influence of the Tribute System on Shaping the Boundary}

Tianxia, as the traditional Chinese view of the world, had long been one important conceptual pillar of the tribute system in shaping ancient China's sense of boundary. As a whole entity, the view of Tianxia considered that the world consisted of many political units in which China was at the centre. It was the Chinese emperor's responsibility to let his virtues nourish all the land, despite the differences between China and nonChinese people. ${ }^{22}$ However, the nourishment from the emperor was not equal to all nonChinese because the influence of the emperor decreased with distance from him. From this perspective, scholars often divide Tianxia into four layers. ${ }^{23}$ The first layer consists of areas that are under the emperor's direct rule, and the scope of this layer is approximately equal to the concept of 'China' in a political and geographical sense. The second layer of the circle is called the inner circle which consists of the closest and culturally similar countries, like Korea and Vietnam. The third layer is called the outer circle and consists of ethnic minority tribes and countries in the periphery of imperial China that were not only ethnically and culturally non-Chinese but also often in conflict with the imperial court. They occasionally posed a threat to the security of China proper and even inverted the tributary relationship when they were well-matched in strength with the imperial court. It is noteworthy that the boundaries between the inner circle and the outer circle were not always clear because they both were located around China proper. Therefore, the distinction between them seems to lie in the recognition of Confucian culture rather than geographical position. The fourth layer consists of the 'out barbarians', who lived at a further distance over land and sea and had little contact with China.

According to the frequency of contact with the imperial court, the political entities established by non-Chinese can approximately be divided into three categories. The first category is the regimes established by the ethnic minorities who lived in the outer circle. As mentioned earlier, these culturally different minorities appeared either in the form of a tribe or, from time-to-time, as a country, and they frequently threatened the survival of the imperial court because these militaristic regimes had a strong sense of

\footnotetext{
${ }^{22}$ Jian Junbo, the Chinese tribute system - Conceptual structure and functions, International Political Studies (2009), $1, \mathrm{p} 138$.

${ }^{23}$ J. K. Fairbank, 'A preliminary Framework' in The Chinese world order: traditional China's foreign relations, Harvard University Press, 1968, p108.
} 
expansibility. The second category refers to those surrounding countries in the inner circle that accepted the Confucian culture, such as Korea and Vietnam. These nonChinese had steadily existed in the form of a country and hardly posed a threat to the imperial court. And the third category is usually directed at those countries in the fourth layer which are far away from China, such as European countries. With regard to the practice of the tribute system, it generally only covered the first two categories because of geographical difficulties between China and the countries in the fourth layer prior to the nineteenth century. Considering that ethnic minority regimes were often in conflict with the imperial court, they were undoubtedly the regimes which had frequent contact with China regardless of the cultural differences. For this reason, the institutions of Huimeng, Heqin and Hushi would be applied to them when they became evenly matched or stronger than the imperial court. And when they were relatively weak and in the form of tribes, the imperial court was inclined to control them indirectly through the institution of Cefeng. In dealing with surrounding countries that accepted Confucian culture, the imperial court preferred to recognise the legitimacy of their rulers through Cefeng and to maintain their dependence on China by rewarding their tribute. ${ }^{24}$

It can be seen from these differences that the tribute system can also be divided into two branches according to the different purposes that imperial court wanted to achieve. The first branch is the tribute system which aims to protect border security from the invasion of ethnic minority regimes in the outer circle, and the second one is the tribute system which is dedicated to developing hierarchical diplomatic relations with surrounding countries in the inner circle. As for those countries far away from China, they were generally beyond the influence of the tribute system. The following discussion focuses on exploring how the tributary relationship with ethnic minority regimes affected imperial China's view of its boundaries.

Historically, the boundaries between the imperial court and the surrounding ethnic minority regimes were not always unambiguous because the political organisation of these regimes changed constantly following changes in the power balance between them and imperial China. When the imperial court was powerful and interested in expanding their influence to the surrounding ethnic minority regimes, it was_inclined to apply a series of measures to bring them into its governance. In contrast, when the

\footnotetext{
${ }^{24}$ Chen Nina (程尼娜), Jimi and Diplomacy: Two Kinds of Tributary System in Ancient China: Centering on Ancient Northeast Asia (羁縻与外交: 中国古代王朝内外两种朝贡体系一一以古代东北亚地区为中心), Collected Papers of History Studies (史学集刊), Vol. 4, 2014, pp 20-28.
} 
imperial court was too weak to exert influence on the ethnic minority regimes, it was inclined to recognise their independence. For those ethnic minority regimes that submitted to the imperial court, they were generally divided into two categories according to the degree of influence that the imperial court could exert over them. They were called external tributary (Wai Fan; 外藩) and internal tributary (Nei Fan; 内藩). ${ }^{25}$ External tributary refers to those ethnic minority regimes which could maintain their independence over internal affairs. Because their status was basically the same as that of the surrounding countries which accepted Confucian culture, they were collectively referred to as external tributary. The internal tributary usually refers to those ethnic minority regimes that could be effectively controlled by the imperial court through the appointment of term-limited officials in these places. ${ }^{26}$ Although the imperial court was inclined to reserve the original governance model of the internal tributary to a certain extent, the internal tributary had_already lost the capacity to manage its affairs because of the imperial court's direct rule. Therefore, it constituted a political unit within the Chinese empire, and the empire's boundaries extended to these ethnic minority regimes.

In the early stage, the difference between the external tributary and the internal tributary was not as clear because the imperial court often initially exerted its influence on them by setting 'Jimi Prefecture' (羁縻府州). The system of Jimi Prefecture was similar to Cefeng, and the native rulers or chieftains were endowed with a Chinese title and thus worked as officials for the imperial court. According to their political power, these native chieftains were invested into the nominal position of a commander-in-chief $(d u d u)$ or regional inspector (cishi) and were given a seal. The titles of native chieftains were hereditary, and the social and political structure of the tribes was not altered. ${ }^{27}$ Unlike Cefeng, the Chinese titles that vested in Jimi still constituted a part of the imperial bureaucratic system, while the titles that vested in Cefeng only symbolised the recognition of the existing status of rulers of surrounding countries by the Chinese emperor. The names of these Jimi Prefectures were often changed over time, and some were abolished while others were created. Sometimes the imperial court sent the termlimited officials to collaborate in administration with these native chieftains and eventually to replace them, therefore, an external tributary was transformed into an

\footnotetext{
${ }^{25}$ John K. Fairbank, The Cambridge History of China, Late Ch'ing, 1800-1911, Part 1, Volume 10, pp 29-34.

${ }^{26}$ Peng Jianying (彭建英), The Evolution of the Jimi Policy in Ancient China (中国古代羁縻政策的演变), China Social Science Press(中国社会科学出版社), 2004, p 11.

${ }^{27}$ Liu Tong (刘统), the Study of Tang Dynasty's Jimifuzhou. (唐代羁縻府州研究) Xi'an: Northwest University Press (西北大学出版社), 1998, pp 17-23.
} 
internal tributary and formed a unique part of the Chinese empire. It can be seen that the criterion for determining the external and internal tributary is whether the imperial court could effectively control ethnic minority regimes to a certain extent.

The above content first discussed the theories of the tribute system; the discrepancy between its theoretical foundation and its practices; and the four institutions in this system. The section also explained the two branches of the tribute system based on their different purposes and the relationship of the tribute system and the ethnic minority regimes with the traditional Chinese boundaries, which involved the distinction between the external tributary and internal tributary. By applying this basic understanding of the tribute system, the following sections mainly focus on an explanation of how Tibet developed from an independent empire to an external tributary and eventually to an internal tributary of the Chinese empire. To this end, the SinoTibetan interactions from the Tang Dynasty to the mid-Qing Dynasty are discussed to evidence this development.

\subsection{The Early Sino-Tibetan Interactions Under the Tribute System-From the Tang Dynasty to the Ming Dynasty}

Compared with ancient Korea and Vietnam, which were deeply influenced by Confucianism, Tibet had long been considered on the fringe of Chinese culture because of its distinct ethnicity and culture. Although Tibet was far away from China proper, the history between the imperial court and Tibet is long. It is well documented that their earliest interactions can be traced back to the Tang Dynasty. This section aims at examining the Sino-Tibetan relations at the initial stage, and it involves the three Chinese dynasties that had frequent contact with Tibet: the Tang Dynasty (唐朝) (618907 AD), the Yuan Dynasty (元朝) (1279-1368 AD) and the Ming Dynasty (明朝) (1368 $-1644 \mathrm{AD}){ }^{28}$

\footnotetext{
${ }^{28}$ Because the limited interactions between Tibet and the Song Dynasty (960-1279), the dynasty between the Tang and the Yuan, thus the author combine the Sino-Tibetan relations during the Song with the description of the Yuan Dynasty.
} 


\subsubsection{The Sino-Tibetan Relations in the Tang Dynasty}

Although no one knows exactly when the first contact between China and Tibet happened, it is generally acknowledged that, according to historical records, the earliest Sino-Tibetan interactions could be dated back to the Tang Dynasty. ${ }^{29}$ It was not until the early seventh century that the Tibetan Plateau was ruled by different local tribes, and this situation finally came to an end when the Great King Song-tsen Gam-po conquered the other tribes and established the first unified empire in the early seventh century, the Tubo Empire. ${ }^{30}$ During the expansion of the Tubo Empire, it inevitably encountered the influence of the Tang Dynasty. According to the Xin Tangshu (新唐书), the interactions between the Tang Dynasty and Tubo mainly included Huimeng and Heqin. ${ }^{31}$

As a rising nomadic empire, Tubo was ambitious to expand its land to the east, and it would inevitably encroach upon the influence of the Tang in China's peripheral area. In this context, the first Sino-Tibetan war occurred when Song-tsen Gam-po attacked the Tang's tributary country of Tuyuhun (吐谷浑) and invaded the Tang's land of Songzhou (松洲). ${ }^{32}$ Over the next two centuries, the Tang and Tubo were in border conflict from time-to-time, and the Tibetan army even temporarily captured the capital of the Tang Dynasty_Chang'an — in 763 AD. ${ }^{33}$ It was evident that the expansion of Tubo once posed a significant threat to the survival of the Tang. Therefore, the Tang were usually inclined to maintain frontier security through initiating Huimeng with the Tibetans. Similar to a peace conference, Huimeng often occurred when the war was temporarily over. There were two core aims of Huimeng. One was to declare a truce between the Tang and the Tubo and to rebuild their friendship; the other was to redefine their boundaries. In order to ensure that the Huimeng was duly respected, its contents were

\footnotetext{
29 "According to Chinese writers, contact was established between China and Tibet as early as 2220 BC...... Definite relations, however, were not established until the Tang Dynasty." Tieh-tseng Li, The Historical Status of Tibet, King's Crown Press, Columbia University, New York, 1956, PP 5- 17; Also see Pu Wencheng (蒲文成), Wang Xinyue (王 心岳), The History of relationships Between the Chinese Han and Tibetan (汉藏民族关系史), Gansu People Publishing Company (甘肃人民出版社), 2008, pp 30-49.

${ }^{30}$ Charles Bell, Tibet - Past and Present, Oxford at the Clarendon Press, 1968, p 23. See the Tang-Tubo boundary in Map I in Appendixes.

${ }^{31}$ See the biography of Tubo (吐蕃传) in the New history of the Tang Dynasty, Ou yangxiu (欧阳修), Song qi (宋 祁), Zhonghuashuju Press (中华书局),1975, pp 6071-6110.

${ }^{32}$ Ibid, pp 6073-74.

${ }^{33}$ Tsepon Wangchuk Shakabpa, One Hundred Thousand Moons: An Advanced Political History of Tibet, Brill, 2010 , p112.
} 
recorded on the stone monuments erected on the border or the capital. ${ }^{34}$ Apart from the Humeng, the institution of Heqin was also adopted by the emperor of the Tang to ease the confrontation with Tubo. Two matrimonial alliances occurred during the Tang Dynasty. In 641, the Emperor Taizong married Princess Wencheng to Song-tsen Gampo; in 710, the Emperor Zhongzong married Princess Jincheng to Tsanpu Tridé Tsuktsen. ${ }^{35}$

As mentioned in the previous section, Huimeng and Heqin were often used to relieve the security threat to the imperial court when the strength of the surrounding ethnic minority regime was approximately equal to or stronger than that of the imperial court. With regard to the Sino-Tibetan relations in the Tang Dynasty, Tubo not only independently dealt with its internal and external affairs but also posed a great threat to the survival of the Tang. Neither Huimeng nor Heqin had formed a political dependency between Tubo and the Tang. For example, in 781, Tsanpu Trisong Detsen made a protest to the Tang representative who conveyed Emperor Dezong's decree because the words used in the decree seemed to put the Tubo in an inferior status compared to the Tang. Consequently, Emperor Dezong agreed to alter the use of words on the basis of equality. ${ }^{36}$ From this perspective, the Tibetans, as the ethnic minorities who lived in the west periphery of China, had completed the transition from tribes to their own country during the Tang dynasty. Considering the Tibetans had not recognised the superiority of the Chinese emperor and had handled their own affairs independent of the Tang's control, the Tubo should be considered as an independent empire in relation to the Tang court.

\subsubsection{The Sino-Tibetan Relations in the Yuan Dynasty}

\footnotetext{
${ }^{34}$ The first Huimeng was concluded in 706, which established the boundary of two parties in the Yellow Reiver (黄 河), and in 733 a new Huimeng was concluded to expand Tubo's border to Chi'ling (赤岭). As a result of Tubo's constant intrusion, in 783 the envoys of two parties gathered in Qingshui (清水) and redefined their borders to Tang's Lin'tao (临洮) and Cheng'zhou (成州). See Zhangyun (张云), Tibet's history of Border Affairs, Governance and Officials (西藏历代的边事边政与边吏), Social Sciences Literature Press (社会科学文献出版社), 2015, pp 78-92; Sun jing's (孙静) dissertation, A Study on the Border Dispute Between the Tang and the Tubo Dynasty (唐朝解决 唐蕃边界争端的方法研究), Lan Zhou University, 2015, pp 34-35.

${ }_{35}$ Tieh-tseng Li, supra n.29, pp 8-9.

${ }^{36}$ The New history of the Tang Dynasty, p 6093. Also see Li Zhonghe's (李中和) dissertation, Study on the Relationship Between Tubo Dynasty and Its Neighboring Ethnic Groups (吐蕃王朝与周边民族关系研究), Lan Zhou University, 2009, p 90.
} 
After the Tsanpu Landarma was assassinated in 842, the Tubo empire collapsed and was once again split into tribes that fought against each other. With respect to China proper, it was ruled by many separatist regimes after the collapse of the Tang Dynasty in 907, and this disintegration lasted until the establishment of the Song Dynasty (960-1279). The Song maintained only limited contact with some eastern Tibetan tribes through setting Jimi prefectures, and the imperial court did not intend to expand its influence to the core area of the Tibetan Plateau. In this sense, the Tibetans existed in the form of tribes that were independent of imperial China. However, the arrival of the Mongols in the thirteenth century fundamentally changed this situation and had a profound impact on later Sino-Tibetan relations. The following discussion focuses on answering two questions: Was the Yuan Dynasty a Mongol Empire or a Chinese dynasty? How did the status of Tibet change through the involvement of the Yuan?

\subsubsection{The Yuan - A Mongol Empire or a Chinese Dynasty?}

The origin of the Yuan Dynasty could be traced back to 1206 when Genghis Khan became the Khan of all Mongol tribes. With the establishment of the Mongolia Khanate, he and his descendants initiated many conquests that expanded their lands west to eastern Europe, east to the Sea of Japan and north to Siberia. In general, these vast lands ruled by the Mongols were called the Mongol Empire. In the process of its military expedition, Genghis Khan's grandson Kublai Khan wiped out the Song Dynasty and occupied China proper in 1279. In the meantime, Kublai established a Mongol-ruled dynasty called the Yuan. Because the traditional Chinese dynasty was basically established by ethnic Hans, some writers argue that Mongols were alien invaders to the ethnic Hans and that during the Yuan Dynasty China proper had become a part of the Eastern Mongol Empire. ${ }^{37}$ And no matter what kind of relationship existed between the Mongolian rulers of Yuan and Tibetans, this relationship was established between Tibetans and Mongolians rather than the Chinese. ${ }^{38}$

One shall not overemphasise the fact that the Yuan Dynasty was established by Mongols nor underemphasise that the Yuan was also a dynasty of imperial China. First, the Yuan

\footnotetext{
${ }^{37}$ Michael C. Van Walt Van Praag, The Status Of Tibet: History, Rights, And Prospects In International Law, Westview Press, 1987, pp 6-7.

${ }^{38}$ Ibid.
} 
established by Kublai was not the Mongol Empire itself or a component of the Mongol Empire. After Genghis Khan's death, the Mongol Empire had gradually fallen apart into four large khanates. ${ }^{39}$ Soon a civil war for the throne broke out among the ruling families and ended with the victory of Kublai Khan. However, the status of Kublai was not recognised by most of the khanates as they had already elected Kublai's opponent as the Great Khan. As a result of the Mongol civil war, the four big khanates refused to obey Kublai's will and ran independently from each other. In this sense, the unified Mongol Empire established by Genghis Khan did not exist anymore, and thus the Yuan established by Kublai was not a Mongol Empire or its component.

Second, whether the Yuan was a Chinese dynasty or not depends on whether China was regarded as a multi-ethnic empire or a nation-State. Nation-States express or strive to embody a common culture, and their principle is homogeneity, often seen in ethnic radical terms. Nation-States accordingly espouse a radical egalitarianism: all members of the nation are in principle equal. In the meantime, nation-States are intensely particularistic as they are generally concerned only with their own way and are convinced that it is superior to the ways of all other nations. Empires, in contrast, appear to exhibit principles opposite to those of nation-States. They are multi-ethnic or multinational. Far from having or seeking a common culture, they stress the heterogeneity of cultures. Empires are hierarchical, opposed in principle to egalitarianism. ${ }^{40}$ Although Confucian culture had long been the dominant ideology in Chinese history, one should not neglect the fact that China since its formation had been an empire with many different nations. For example, emperors of the Sui and the Tang dynasties were often regarded as descendants of Xianbei, a nomadic nation in northern China, and their orthodoxy was rarely questioned as they genuinely accepted the Confucian culture. Given this, it is not difficult to understand the reason the Hans regarded the Mongolian rulers, on the one hand, as emperors and, on the other hand, as invaders due to their different civilization. With regard to the administration of the Yuan dynasty, instead of transforming China into a nomadic empire, the emperor of the Yuan not only inherited the political system of the previous dynasties but also innovatively set up a provincial system to divide China proper into different administrative units, s system that had a profound influence on China's political structure and has been used up to now.

\footnotetext{
${ }^{39}$ They were the Golden Horde khanate in the northwest; the Chagatai Khanate in Central Asia; the Ilkhanate in the southwest; and the House of Ögedei around near the Xinjiang toady which belonged to Genghis Khan's successor Ögedei.

${ }^{40}$ Krishan Kumar, Nation-States as Empires, Empires as Nation-States: Two Principles, One Practice? Theory and Society volume 39, 2010, pp 121-22.
} 
Furthermore, although most of the high officials were Mongols, the emperor of Yuan had to rely on numerous Han bureaucrats to rule his vast empire. In traditional Chinese history, the current imperial court had an obligation to codify the history of the previous dynasty in order to learn lessons from the past. The Ming Dynasty, as the successor of the Yuan, followed this tradition and codified the history of the Yuan. No matter from the perspective of empire-building or succession of dynasties, there is thus no doubt that the Yuan was a Chinese dynasty, although not such a typical one. ${ }^{41}$ For the same reason, there is no doubt that the interactions between the Yuan and Tibet were not only Mongol-Tibetan relations but also Sino-Tibetan relations.

\subsubsection{The Status of Tibet in Yuan-Tibetan Relations}

Contact between Mongols and Tibetans began in 1240 when Prince Godan, the second son of Ögedei Khan, sent an army to Ü-Tsang seeking Tibet's submission. To conquer Tibet for a small price, Godan invited one of Tibet's leading religious hierarchs, Sakya Pandita, to his court. The Sakya lama arrived in 1247 and made a full submission of Tibet to the Mongols. After that, Sakya Pandita wrote a long letter to other leaders of Tibetan Buddhist sects, pointing out that it was futile to resist the Mongols and instructing them to pay the required tribute. ${ }^{42}$ Thus a relationship called 'patron-priest' was established between the Mongols and Tibetans. ${ }^{43}$ Sakya Pandita died in 1251, and his nephew Phagpa replaced him as leader of the Sakya sect. In the meantime, Kublai, while preparing to wipe out the Song Dynasty, invited Phagpa to his barrack and appointed him as his tutor in 1253.Kublai also set up the Bureau of Buddhist and Tibetan Affairs (initially named Zongzhi Yuan and renamed as Xuanzheng Yuan) to

\footnotetext{
${ }^{41}$ The idea that the regime or government of one place can only be established by the peoples who live here for generations did not always accord with the practices. For example, no one can deny that the history after the Norman conquest was not belong to the history of England. Similarly, although India was invaded and occupied by Islamized Mongols from the $16^{\text {th }}$ Century, whereas few scholars have attempted to suggest that the Mughal Empire was a Mongol or Islamic Empire or the territories it occupied was not India anymore. On the contrary, it is widely acknowledged that the Mughal Empire played a profound role in Indian history. For this reason, the judgement which limited the Chinese dynasties to the establishment of the Han people was also not compatible with historical practice. 42 'Tibet had already paid tribute to Genghis Khan in 1207, and Mongol forces did not invade Tibet or interfere in the administration of its principalities. The death of Genghis Khan in 1227 produced important changes. Tibetans ceased sending tribute to Mongolia and the new supreme Ogedai Khan, ordered a cavalry force under the command of his son Godan into Tibet.' See Melvyn C. Goldstein, The Snow Lion and the Dragon - China, Tibet, and the Dalai Lama, University of California Press, 1997, p 3; The content of Sakya's letter, see Shakabpa, supra n.33 pp 6364.See the Yuan-Tibet boundary in Map II in Appendixes.

${ }^{43}$ Tibet's lama provided religious instruction; performed rites, divination, and astrology; and offered the khan flattering religious titles like 'protector of religion' or 'religious king'. The khan, in return, protected and advanced the interests of the 'priest' (lama). The lamas also made effective regents through whom the Mongols ruled Tibet. Melvyn C. Goldstein, ibid.
} 
supervise the Buddhist affairs as well as the administration of Tibet in 1264, and he appointed Phagpa as the chief of the Zongzhi Yuan. In 1269, Phagpa was conferred with the title of the imperial preceptor. After Phagpa was appointed as the chief of the Zongzhi Yuan, he came back to Tibet and established a Sakya regime to deal with Tibetan affairs. ${ }^{44}$ At this point, the Sakya regime began to become the de facto authority of Tibet, although its influence did not reach the entirety of Tibet. After Kublai established the Yuan Dynasty in 1271, he divided the territory of the Yuan into ten Xing Zhongshu sheng (provinces) and put them under the administration of a central secretariat-Zhongshu Sheng. But he still placed Tibet under the jurisdiction of Zongzhi Yuan rather than bringing it into direct administration.

Through the above discussion, it can be seen that Tibetans had already submitted to the Mongols before the Yuan Dynasty was established. When Kublai established the Yuan Dynasty, he did not transform Tibet into a province and kept it under the jurisdiction of Zongzhi Yuan. Since the imperial preceptor was the chief of Zongzhi Yuan and the imperial preceptor needed to maintain his influence on Tibet through the Sakya regime, Tibet had basically retained its independence from the Yuan's direct control. But one also should bear in mind that neither the imperial preceptor nor the Sakya regime could obtain a dominant position in Tibet without the support of the emperor of the Yuan. The imperial preceptor in the imperial court was more like an intermediary between the emperor and the Tibetans. ${ }^{45}$ The emperor confirmed the Sakya's dominant position by appointing the imperial preceptor and providing him with considerable political, military and economic support. In this sense, the Sakya regime showed a strong dependence on the imperial court while also keeping its independence. ${ }^{46}$ Although the Sakya regime possessed an overwhelming position over other rivals and functioned like a de facto government, Tibet can hardly be considered as a unified country due to its political split. It was more like a transition from tribes to a country. In the meantime, as

\footnotetext{
${ }^{44}$ The main functions of this regime include managing and coordinating different Buddhist sects and monks in Tibet; making sure that the orders of the imperial preceptor and the Yuan emperors' decrees could be implemented; and dealing with administrative affairs in Ü-Tsang, such as household registration, tax collection and handling the litigations. See Chen Qingying (陈庆英), A Complete History of Tibet (Xi Zang Tong Shi), Zhongzhou Guji Press (中州古籍出版社), 2003, p 196.

${ }^{45}$ According to pervious agreement between Kublai and Phagpa, on matters regarding Tibet, Kublai should follow the wishes of Phagpa and he shall not issue orders without consulting the imperial preceptor. See Anon, The Mongols and Tibet, Dharmsala, India, DIIR of the Central Tibetan Administration,1996, p 14; Also see Dawa Norbu, China's Tibet Policy, Curzon Press,2001, p 48.

${ }^{46}$ For example, the high officials of the Sakya regime were usually first nominated by imperial preceptor, then they still needed to get the emperor's approval before came into power. Chen Qingying (陈庆英), Study on the Ponchen in Sakya regime in the Yuan Dynasty (元代萨迦本钦辨析), the Collection of Tibetan Studies, Volume 2 (藏学研 究论丛, 第 2 辑), Tibet People's Publishing Press (西藏人民出版社), 1990, pp 94-1138.
} 
the emperor of the Yuan lacked the intention to bring Tibet into his direct control and was inclined to exert his influence on Tibetans through appointing imperial preceptors, the Yuan's policy towards Tibet possessed a character of Jimi Prefecture. ${ }^{47}$ From this perspective, Tibet had correspondently turned into an external tributary of the Yuan court. Some writers describe the relationship between the emperor of the Yuan and Tibetans as a 'priest-patron' relationship that included two elements. The first element is that the Tibetan lama provided the emperor with religious instruction; the second element is that the emperor provided the lama with protection and advanced the interests of the lama. ${ }^{48}$ These writers simplify this 'priest-patron' relationship as a personal and religious one, but they neglect its political significance in shaping the status of Tibet because both the emperor and the lama were political figures, and their relationship could only be a political one wrapped with religious colour rather than a religious one decorated by politics. ${ }^{49}$ Religiously, the emperor can treat the lama as a teacher, but in the political field, the lama can never regard himself as another monarch equal to the emperor. ${ }^{50}$

\subsubsection{The Sino-Tibetan Relations in the Ming Dynasty}

The Sakya family ruled in Tibet for nearly a century until they were overthrown in 1358 by Changchub Gyaltsen, who established the Phamo-drupa regime and ruled U-Tsang for 97 years. ${ }^{51}$ At the same time, the Yuan Dynasty was also soon overthrown by Zhu Yuanzhang (朱元璋) who established the Ming Dynasty (1368-1644).

In 1369, Zhu Yuanzhang, the founder of the Ming, began to send missions to Tibet. The first mission was aimed at informing the Tibetans that the Ming was established to

\footnotetext{
${ }^{47}$ Liu Tong, supra n.27.

${ }^{48}$ Michael C. Van Walt Van Praag, supra n.37 pp 12-3; Tsepon Shakabpa, supra n.33, pp 199-239.

${ }^{49}$ Deng Lie, Study on the Historical and Legal Status of Tibet in International Law, Chinese National Social Science Fund Project, 2013, pp 63-8.

${ }^{50}$ Ibid.

${ }^{51}$ In the middle of the $14^{\text {th }}$ century Changchub Gyaltsen (1302-1364), who in 1322 had become one of the thirteen governors of administrative called myriarchy (Wanhu Fu; 万户府) established by the Yuan Dynasty in the second half of the 13th century. Changchub Gyaltsen was named the myriarch of the Phamo-drupa administrative unit with the seat in Sne-gdongrtse in the region of Dbus. During the years 1349-1354 he revolted against the authority of the Sakya family and became the de facto ruler of Central Tibet. In 1365 his status was recognized by the Yuan Dynasty and thus he became the founder of the Phamo-drupa regime. See Martin Slobodnik, The Relations Between the Chinese Ming Dynasty and the Tibetan Ruling House of Phag-mo-gru in the Years 1368 - 1434, Political and Religious Aspects, Asian and African Studies, 13, 2004, pp 155 - 71.
} 
replace the Yuan. ${ }^{52}$ Few positive responses were heard from the Tibetans. Thus, the Emperor sent a second mission, and this mission was aimed at persuading the Tibetan chieftains who had accepted the title of the Yuan to receive the title from the Ming court. ${ }^{53}$ The Phamo-drupa regime, as the de facto regime in central Tibet, initially sent envoys to the Ming court, and the emperor bestowed the title 'anointed national preceptor' to the ruler of Phamo-drupa. Apparently, the bestowal of the title from the Ming only had a symbolic and ceremonial character considering its weak influence in central Tibet. ${ }^{54}$ However, in eastern Tibet, the Ming court had reinforced its influence in order to defend the north-western borders from the Mongol's harassment. The Ming court set many garrisons called Weisuo (卫所) in the peripheral regions of the South Gansu and West Sichuan provinces. ${ }^{55}$ These measures inevitably aggravated the tension between the Ming court and local Tibetans. ${ }^{56}$ For this reason, the Ming court, on the one hand, sent troops to suppress the revolts of local chieftains and, on the other hand, granted these local chieftains and lamas imperial title and gifts to relieve the conflict. ${ }^{57}$ In the Ming court's strategy, the Weisuo not only functioned as military facilities but also as civil administrations in eastern Tibet. The Ming usually appointed term-limited Han officials as the head of the stations; in the meantime, the local Tibetan chieftains were also appointed as high officials to assist the Han officials, and their descendants could inherit their imperial posts. ${ }^{58}$

Based on the different degree of the Ming's influence on Tibetans, Tibet could be divided into two geographical regions in the Ming Dynasty: one was central Tibet and

\footnotetext{
${ }^{52}$ The proclamation that it carried has been preserved in the Ming shi-lu (明实录), the translation of the edict see Elliot Sperling, The $5^{\text {th }}$ Karma-pa and Some Aspects of the Relationship between Tibet and the Early Ming Dynasty, in the History of Tibet, Volume II, Routledge Curzon, pp $478-479$.

${ }^{53}$ Namgyal Palzangpo, the last acting imperial tutor of the Yuan Dynasty from Sakya went to the Ming capital in 1371 to report. The new Ming emperor was so glad with Palzangpo's submission that he at once appointed the lama as state tutor and gave him a jade seal. With Palzangpo's recommendation, approximately 100 ex-Yuan title holders were given new Ming titles. See Norbu, supra n.45, p 59.

${ }^{54}$ Martin Slobodnik, pp 155-71.

${ }^{55}$ Mingshi (明史), volume 28, Zhang tingyu (张廷玉), Zhonghua Book Company (中华书局), 1974, p 8539. Besides, the Ming court set up the Bureau of Tea and Salt Transportation in Sichuan (四川等处茶盐都转运司) and the TeaHorse Trading Office in Qinzhou (秦州茶马司) to manage Tibetan affairs in the economic field and developed teahorse trade with Tibetan-inhabited areas from Sichuan and East Gansu. See Luo Zhao, The Status of China's Sovereignty in Tibet during the Ming Dynasty, China Tibetology, No. 1, 2015, pp 1-53.

56 "At times there were rather violent periods along the frontier making it somewhat dangerous for missions travelling between Tibet and China. Nevertheless, missions did get through most of the time, and the fact that hostilities and embassies directed at China were often undertaken at the same time by different parties underscores the limited extent of centralized Tibetan authority of any kind in the frontier regions during this period." Elliot Sperling, The 5th Karma-pa and Some Aspects of the Relationship between Tibet and the Early Ming Dynasty, p 474.

${ }^{57}$ Mingshi, pp 8541-42.

${ }^{58}$ Wang Jiguang (王继光), The Modern Explanation of Military Garrison Stations in Amdo in the History of the Ming (18 世纪中国第一部安多藏区史 - 《明史西番诸卫传》的现代诠释), China Tibetology (中国藏学), No.4, 2006, pp 22-33.
} 
the other was eastern Tibet. Although the Ming court wished to extend its authority to central Tibet, which was controlled by the Phamo-drupa regime, its influence in this area could not be compared with that of the Yuan Dynasty. Therefore, central Tibet maintained its independence throughout the Ming Dynasty. As for eastern Tibet, the Tibetan tribes that were transformed into Weisuo should be regarded as internal tributaries of the Ming considering that the Ming had already been deeply involved in the internal administrative affairs of the region.

\subsection{The Status of Tibet in the Qing Dynasty}

In the latter part of the Ming Dynasty, it was almost destroyed by the peasant uprising in 1644. The Manchu, an ethnic minority in the north which had once submitted to the Ming, had grown, and it finally wiped out the Ming Dynasty and had established another ethnic minority dynasty-the Qing. Similar to the Ming Dynasty, the Mongols' harassment also constituted a great threat to the emperor of the Qing Dynasty. In this context, the emperor of the Qing attached great importance to the role of Tibet, given that most Mongols were Tibetan Buddhist followers. In this section, a brief introduction is given to show how the Dalai Lama emerged in the Mongol-Tibetan interaction. After this, the section focuses on a discussion of how the Qing court transformed from an independent country into an external tributary and, finally, into a part of the Qing Empire before the Western State's encroachment in the1840s.

\subsubsection{The Emergence of the Dalai Lama}

During the Yuan Dynasty, Tibet was dominated by several Buddhist sects such as Sakya and Kargyu. The Geluk section led by the Dalai Lama emerged in the early fifteenth century. Due to the corruption and moral decline of the other major sects, an eminent monk named Tsongkapa was committed to preaching a reformist doctrine in central Tibet, and this was the origin of the Geluk. ${ }^{59}$ With the growing influence of the Geluk Sect, the prestige of Sonam Gyasto, who was the third-generation leader, was heard by

\footnotetext{
${ }^{59}$ Geluk means "the system of virtue" in Tibetan. This sect emphasized strict monastic vows of celibacy, and scholastic study as the path for enlightenment. To differentiate themselves from the earlier sects, the followers of Tsongkapa took to wearing yellow instead of red hats and thus have come to be known as the Yellow Hat sect. See Melvyn C. Goldstein, The Snow Lion and the Dragon, p 5.
} 
the powerful Mongol ruler Altan Khan of the Tumad tribe. At Altan Khan's invitation, Sonam Gyasto met him in Amdo. During the meeting, they exchanged honorific titles with each other. The lama conferred the Khan with the title 'King of religion, majestic purity' and, in return, the Khan conferred the lama with the Mongolian title of 'Dalai', which means the Ocean, to imply that his knowledge was as vast as the Ocean. ${ }^{60}$ Although Sonam Gyasto was the first lama to hold that title, he was still called the third Dalai Lama because he was the third incarnation in the Geluk section. When he died in 1588 , his reincarnation was found in the family of Altan Khan and was escorted back to Lhasa in 1601 by Mongolian followers. Since then, the Geluk section has formed a close association with the Mongols.

The rapid expansion of the Geluk endangered the superiority of other big sects, such as Karma Kargyu which was closely allied with Tsangpa King, the political rulers of Tibet. ${ }^{61}$ Out of fear of being wiped out by Tsangpa King, the Geluk turned for help from their Mongol supporter-Gushri Khan, the ruler of Khoshut tribe. Gushri Khan immediately answered the lama's request and expelled the anti-Geluk forces from eastern Tibet. After Gushri Khan captured central Tibet in 1642, he executed the Tsangpa King and enhanced the fifth Dalai Lama to supreme status. Instead of withdrawing the troops and returning home, Gushri Khan stayed in Lhasa and took the title of Tibetan King. ${ }^{62}$ Although the Geluk had unified the whole of Tibet under the leadership of the Dalai Lama, to some extent they had to follow the orders of Gushri Khan. ${ }^{63}$

\subsubsection{The Qing's Early Involvement in Tibetan Affairs}

With the help of Gushri Khan, the fifth Dalai Lama established a civil administration known as the Ganden Phodrang regime. With the rapid rise of the Manchu in north China, the fifth Dalai Lama decided to contact the Manchu regime, and he sent envoys to Manchu's former capital, Mukden, in 1643. Emperor Taizong received the Dalai

\footnotetext{
${ }^{60}$ Ibid, p 8.

${ }^{61}$ In a dispute between Geluk and Tsangpa king in 1618, the king's troops killed many Geluk monks and prohibited a search for the incarnation of the fourth Dalai Lama.

${ }^{62}$ The fifth Dalai Lama himself also admitted that: "All Tibetan aristocratic leaders paid allegiance to the Gushri Khan, thus the Khan became the King of whole Tibet.” See A History of Tibet by the fifth Dalai Lama (西藏王臣 记), translated by Liu Liqian (刘立千), Publishing House of Minority Nationalities (民族出版社), 2000, p 128.

${ }^{63}$ Ibid.
} 
Lama's envoys with high honours and gifts. ${ }^{64}$ After the Manchu entered Beijing and established the Qing Dynasty in 1644, a new invitation from Emperor Shunzhi was sent to the fifth Dalai Lama, and the latter accepted the invitation and arrived in Beijing in 1652. During his stay there, he was warmly treated with great respect and courtesy by the emperor. ${ }^{65}$ As a mark of mutual respect, Emperor Shunzhi reaffirmed the title of 'Dalai Lama' given to Sonam Gyasto through imperial edict, and the Dalai Lama, in return, recognised the Emperor as the incarnation of Bodhisattva Manjushri. Although the first official contact had taken place, there was no proof that any formal relationships had been established between them. ${ }^{66}$

After the fifth Dalai Lama died in 1682, the politics of Tibet once again fell into a chaotic situation. Sangye Gyatso, the regent of Tibet at that time, concealed the news of the Lama's death and maintained his rule in the name of the fifth Dalai Lama for fourteen years. To expel the military power of Khoshut Mongol from Tibet, Sangye Gyatso secretly contacted the powerful Dzungar Mongols and asked them for help. For the Qing court, the Dzungars were the last threat that possessed the capacity to challenge the supremacy of the Qing. Although Emperor Kangxi won a decisive victory against the Dzungars in $1696,{ }^{67}$ he was still surprised at the untrustworthiness of the regent when he heard of the Dalai Lama's death. Therefore, he wrote a letter to the regent, expressing his dissatisfaction with the regent's role in concealing the Dalai Lama's death and secretly colluding with the Dzungars, and he intimidated to the regent that he would send an army to Tibet if the regent obstructed the Panchen Lama to visit Beijing. In his reply, the regent explained the reason he had concealed the death of the Dalai Lama and asked the emperor not to divulge the news of the Lama's death. He also mentioned that the reincarnation of the fifth Dalai Lama had been found under his supervision. ${ }^{68}$ Considering the Qing's limited influence in Tibet, Emperor Kangxi agreed to the regent's request. Subsequently, the regent officially announced the young reincarnation as the sixth Dalai Lama in 1697. However, with the expansion of the

\footnotetext{
${ }^{64}$ Ya Hanzhang (牙含章), The Portrait of Dalai Lama (达赖喇嘛传), SDX Joint Publishing Company (三联书店), $1963, \mathrm{p} 20$.

${ }^{65}$ The Emperor traveled outside Beijing to receive the Dalai Lama, and he descended from his throne and walked 20 yards to greet his guest at their first meeting. See Michael C. van Praag, p 11.

${ }^{66}$ Josef Kolmas, Tibet and Imperial China - Survey of Sino-Tibetan relations up to 1912, Centre of Oriental Studies, Australian National University, 1967, pp 35-6.

${ }^{67}$ During that time, the Emperor Kangxi still believed the fifth Dalai Lama was alive and asked he use his religious influence to persuade the Dzungars to stop their invasion. Without informing the emperor that the Dalai Lama was dead, but the Tibetan regent, in the Dalai Lama's name, refused to support the emperor in his struggle against the leader of Dzungars Galdan. See Josef Kolmas, p 36.

${ }^{68}$ Ya Hanzhang, pp 24-5.
} 
regent's power, his behaviour inevitably caused strong dissatisfaction from Gushri Khan's successor, Lhabsang Khan. Their relationship quickly deteriorated in 1705 when Lhabsang, who obtained the support of the Qing emperor and allied with many Tibetan aristocrats, killed the regent in Lhasa. ${ }^{69}$ Soon afterwards, Emperor Kangxi sent an envoy to Lhasa and recognised the Khan as ruler of Tibet under the Qing's protection. To reinforce Lhabsang Khan's position in Tibet, the emperor also dispatched the first Manchu commissioner to Lhasa to assist Lhabsang in dealing with Tibetan affairs. This measure is often considered as the Qing court's first attempt to directly intervene in Tibetan affairs. ${ }^{70}$ With the approval of Emperor Kangxi, Lhabsang Khan announced that the young reincarnation who was found by the regent was not the real sixth Dalai Lama, and claimed another monk as the real sixth Dalai Lama. ${ }^{71}$ The acts of Khan apparently aroused the anger of monks and ordinary Tibetans. Once again, the Khan's opponents turned to the Dzungars for help. In 1717, Dzungar cavalrymen entered Tibet and defeated Lhabsang Khan. The success of the Dzungars' expedition to Tibet quickly drew the Qing's attention. In response, Emperor Kangxi successively dispatched two armies to Lhasa for the purpose of restoring order there. After the Dzungars were defeated in eastern Tibet by the Qing army, the new seventh Dalai Lama was placed on the throne by the Qing army. This event paved the way for the Qing's future administration of Tibet.

\subsubsection{The Establishment of Qing's Rule in Tibet}

After entering Lhasa, a lot of measures were taken by the Qing court in regard to the Tibetan administration. First, the Qing formally installed the new reincarnation as the seventh Dalai Lama and executed the officials appointed by the Dzungars. Second, a garrison with three thousand soldiers was set up in Lhasa to strengthen the Qing's influence in Tibet. ${ }^{72}$ Third, the position of regent was replaced by a four-person Ministerial Council. From the above measures, it can be seen that the emperor was not

\footnotetext{
${ }^{69}$ The sixth Dalai Lama turned out to be totally deviant in attitude and values, refusing to play the role of a celibate religious practitioner. He renounced his monastic vows and became a famous libertine, writing love poems and carousing with women at night in Lhasa. See Melvyn C. Goldstein, The Snow Lion and the Dragon, p 12.

${ }^{70}$ Josef Kolmas, pp 37-9.

${ }^{71}$ The sixth Dalai Lama recognized by the regent died on the road to Beijing. Before his death, he wrote a poem said that people will find his reincarnation in Litang. For that reason, most Tibetans and Mongols refused to acknowledge the young monk found by Lhabsang Khan as the true sixth Dalai Lama. Instead, as the poem told, a child, who had been born in Litang, was identified as the reincarnation of the sixth Dalai Lama.

${ }^{72}$ Tieh-tseng Li, supra n.29, p 40.
} 
interested in exerting direct control in Tibetan affairs. Instead, his strategy was aimed at enhancing the Qing's influence on Tibetans while leaving the administration of Tibet in the hands of Tibetan leaders.

The Qing's 1720 reform did not work well as the political stability of Tibet was soon challenged by conflicts between the Tibetan ministers. In 1727, a civil war broke out after Khangchennas, the chief minister, was killed by the three other ministers. The civil war lasted for two years and ended with Pholhanas's victory. ${ }^{73}$ When Emperor Yongzheng heard of the news of the coup, he sent an army to Lhasa. However, Pholhanas had already calmed the situation. ${ }^{74}$ In this context, the Qing court appointed Pholhanas as the chief administrator of Tibet and sent the seventh Dalai Lama into exile in eastern Tibet, along with his father who was involved in the coup. In order to further stabilise the situation in Tibet, the emperor in 1728 decided to dispatch two imperial residents known as amban to Lhasa to supervise the Tibetan ruler and manage the garrison. At this stage, the two ambans merely acted as informers with the duty of reporting the events of Tibet to the emperor. ${ }^{75}$ The peaceful situation of Tibet remained until the death of Pholhanas in 1747. Gyurme Namgyal, the son of Pholhanas, whose view on the Qing court differed from that of his father, inherited the position of the chief administrator and began to rid Tibet of the Qing's influence by persuading Emperor Qianlong to withdraw all troops and ambans from Tibet. ${ }^{76}$ At the same time, he secretly sought to allay with the Dzungars. Upon learning of Gyurme Namgyal's scheme, the two amban deliberately invited him to their office and killed him. They were then killed by Gyurme Namgyal's followers. When Emperor Qianlong received the news, he immediately dispatched a military expedition to Lhasa. After the turmoil ended, an imperial decree called 'Thirteen Articles Ordinance for the More Efficient Governing of Tibet' was issued by the emperor to reorganise the Tibetan political system. According to this decree, the secular power of the Dalai Lama was restored,

\footnotetext{
${ }^{73}$ Pholhanas was a regent in Tibet. Between 1728 and 1747, he was practically king of Tibet. See Melvyn C. Goldstein, The Snow Lion and the Dragon: China, Tibet, and the Dalai Lama, pp 13-7.

${ }^{74}$ Because Tibet's ministers complained that it was difficult to maintain so many the Qing troops in so remote area as Tibet, the Emperor Yongzheng had withdrawn the garrison in 1722. Consequently, he had to dispatch another imperial troop to Lhasa. Melvyn C. Goldstein, The Snow Lion and the Dragon: China, Tibet, and the Dalai Lama, $p$ 15.

${ }^{75}$ H.E. Richardson, Tibet and Its History, Boullier \& London, 1984, p 52.

${ }^{76}$ Since Tibet had been peaceful and unproblematic for the previous two and a half decades, the emperor agreed to reduce the Lhasa garrison to a token one hundred troops and instructed the ambans in Lhasa not to interfere in Tibet's administration. He also agreed to send additional funds to cover the expenses of the ambans and troops, thus reducing the need for corvees (that is, taxation in the form of forced labor) to obtain goods and services. Melvyn C. Goldstein, The Snow Lion and the Dragon: China, Tibet, and the Dalai Lama, p 18.
} 
and the role of amban was also enhanced in handling the Tibetan internal affairs. ${ }^{77}$ Henceforth, the Tibetans could no longer decide their affairs independently, although the Dalai Lama was reaffirmed as the secular and spiritual ruler of Tibet. From this perspective, Tibet had become an external tributary of the Qing at this stage.

The above-mentioned reform was carried out until the Tibet-Gurkha war took place from 1788 to $1792 .{ }^{78}$ After the Qing troops defeated the Gurkhas, another imperial decree named 'Twenty-Nine Regulations for Better Government in Tibet' was issued by the emperor that altered the Qing's previous Tibetan policy. Unlike the previous decree, the regulations in this decree significantly expanded the ambans' power in the following respects: (1) ambans were authorised to participate in the administration of Tibet and enjoyed equal political authority with the Dalai Lama and the Panchen Lama on all Tibetan affairs; (2) all Tibetan lay officials and clerical staff had to submit all crucial issues to ambans for a decision, including high appointment, judicial, financial and other matters; (3) ambans were responsible for the defence of the frontier, the administration of finances and were in charge of all Tibet's foreign intercourse and trade ${ }^{79}$ (4) the Dalai Lama and Panchen Lama were deprived of the right to report directly to the emperor, and they could only report to the emperor through ambans; (5) the important incarnations, such as the Dalai and Panchen Lamas, could only be selected by drawing lots in the golden urn under the supervision of ambans to prevent

\footnotetext{
${ }^{77}$ The main administrative changes can be summarized as follows: (1) The institution of a hereditary "kingship" in Tibet was abolished; (2) The Dalai Lama was made nominal head, spiritual and temporal, of Tibet, and the Ministerial Council, the chief executive organ in Tibet, was subordinated to him. (3) The former system of a four-member Ministerial Council which obtained during the period from 1721 to 1727 was restored, consisting of four ministers, of whom three were secular and one a monk. (4) The powers of the Ambans were enlarged. Apart from commanding the Chinese garrison of Lhasa and being responsible for the mail service between Cheng Du and Lhasa, they were given a limited right to take part in the government, which provided them with the opportunity to influence the dayto-day policy of the Tibetan government. See Josef Kolmas, supra n.66, p 46.

${ }^{78}$ The Gurkha are a people from Nepal and the north of the Indian state of West Bengal, and they state that they are descended from the Rajputs of northern India. These Rajputs entered modern Nepal from the west. In the early 16th century, they conquered the small state of Gorkha and adopted its name. By the year 1769 , the Gorkha dynasty had expanded its rule over the whole area of modern-day Nepal. In 1788 the Gurkhas invaded Tibet under the pretext that the Tibetans were conducting the export of goods from Tibet in a fraudulent manner, and levying taxes on Gurkha merchandise. The Tibetans were quickly defeated, and were forced to promise to pay the Gurkha government a huge sum of money annually. Provoked by the Tibetans' failure to pay the promised amount, the Gurkhas attacked Tibet once more in 1791. The emperor then sent a strong army of over ten thousand men, under General Fu K'angan, which defeated the Gurkhas and drove them to the very neighborhood of Kathmandu, the capital of Nepal.

${ }^{79}$ For example, in the economic field, a new uniform currency bearing the title of the emperor was issued by Tibetan treasury to replace the old money coined by Gurkhas, and a mint factory with Chinese experts was established; As to foreign trade, everyone engaged in foreign trade was required to produce a passport and submit to examination by the frontier guards, who reported to the ambans; In the field of taxation, the ambans were invested with the power to examine the revenue and expenditure; And in the field of the foreign relations, all communications with neighboring states such as Nepal, Sikkim and Bhutan were to be through the ambans, even communications addressed to the Dalai Lama and Panchen Lama were to be made known to the ambans. See Tieh-tseng Li, The Historical Status of Tibet, pp 54-5.
} 
the manipulation of powerful lay families. ${ }^{80}$ Meanwhile, the management of Tibetan affairs at the central government level was entrusted to the Lifan Yuan (the Board for National Minority Affairs), which was responsible for supervising the regular payment of tribute, recommending the bestowal of titles on local nobility, and proposing the amount of their income from the imperial treasury. ${ }^{81}$ The establishment of the supreme authority of amban marked that the Qing court formally abolished the independence that Tibet had enjoyed for a long time. Since then, the Manchu resident in Lhasa ruled Tibet on behalf of the Qing emperor. ${ }^{82}$ With regard to Sino-Tibetan relations at this stage, these interactions can hardly be explained by applying the theory of a "priestpatron' relationship which emphasises that the protection of a patron did not imply the superiority of the patron over the priest. ${ }^{83}$ The 'protection' of the Qing court obviously came from the emperor's own will rather than the request of the Tibetans. Furthermore, these reform measures aimed at deep involvement in Tibet's internal and external affairs were not a protection of Tibet but rather a direct intervention in Tibet. Although the effectiveness of these reform measures is questioned by some scholars, ${ }^{84}$ these reform decrees were obviously of great value in the legal sense because it was the first time in history that direct jurisdiction of the central government over Tibet was clearly manifested in the form of imperial legal documents, and no evidence revealed that the Tibetans were opposed to these reform measures. Consequently, considering that the Qing court had already possessed the capacity of effective control in Tibet, the latter should be regarded as an internal tributary within the boundaries of the Qing Dynasty.

In conclusion, the status of Tibet had gone through a gradual change during the Qing Dynasty before the involvement of Western powers. To eliminate the Mongol threat, the emperor of the Qing had initially and actively developed a friendship with Tibetan rulers and attempted to expand the Qing's influence in Tibet. But at this stage, the Qing's influence was too limited to control the administration in Tibet. In this sense, the Sino-Tibetan relations during the early Qing Dynasty were based on equality, and Tibet maintained its independent status in its relations with the Qing. Through frequent military campaigns, the Qing became deeply involved in Tibetan affairs, but did not

\footnotetext{
${ }^{80}$ The content of the regulation can be found in Ya Hanzhang, The Portrait of Dalai Lama, 1963, pp 43-52; Josef Kolmas, p 48. See the Qing-Tibet map in Map III in Appendixes.

${ }^{81}$ Zhao Yuantian (赵云田), A Brief Review on Administration of Lifan Yuan Over Tibet During the Qing Dynasty (略谈清代理藩院对西藏的治理), Tibetan Studies (西藏研究), 1984, volume 3, pp 94-95.

${ }^{82}$ Sir J. F. Davis, China During the War and Since the Peace, Volume 1, Longman, Brown, Green, and Longmans, 1852 , p 149.

${ }^{83}$ Tsepon Wangchuk Shakabpa, p 486.

${ }^{84}$ Michael C. Van Walt Van Praag, p 21.
} 
seek to bring Tibet into direct rule. It instead adopted a policy of indirect control by setting up amban to restrict the rule of Tibetan aristocratic officials and the Dalai Lama. The ambans at this stage only enjoyed a limited right of supervision in Lhasa compared to those who were appointed after the reform of 1793. In this sense, the Qing court had implemented a kind of indirect rule over Tibet by presenting its representative there. Tibet thus lost its independence and became an external tributary of the Qing Dynasty. After the suppression of the Gurkha invasion, for the first time in Sino-Tibetan history, Emperor Qianlong claimed the Qing's direct control over Tibet in the form of imperial law. At that time, Tibet became an internal tributary within the boundaries of the Qing Empire.

\section{Conclusion}

This chapter explored the development of Tibet's status from the Tang Dynasty to the mid-Qing Dynasty before the Western State's encroachments in the nineteenth century within the framework of the tribute system. By comparing different definitions of the tribute system, the first part of the chapter not only discussed the theoretical foundation of this system but also analysed its flexibilities by explaining the discrepancy between the theory of the tribute system and its practice. In addition, the four basic institutions of the tribute system-Cefeng, Hushi, Huimeng and Heqin-were also discussed to clarify the rights and duties governing the relations between the imperial court and the surrounding countries and ethnic minority regimes. The chapter subsequently explored ancient China's sense of boundary under the tribute system by showing the distinction between the external tributary and the internal tributary. The second section of the chapter focused on explaining the development of Tibet's status under the tribute system. By analysing the Humeng and Heqin between the Tang Dynasty and the Tubo Empire, it can be seen that Tibet should be regarded as an independent country during the Tang Dynasty. In the Yuan dynasty, Tibet had submitted to the emperor of the Yuan, and was not independent of the Yuan court because of the dependency of the Sakya regime on the Yuan. On the other hand, due to the lack of direct control of the Yuan court in Tibet, Tibet should be considered as an external tributary to the Yuan court. In the Ming Dynasty, the Ming court only exerted limited influence on central Tibet through Cefeng; the influence of the Ming in eastern Tibet was more reliable than in central Tibet because of the establishment of the Weisuo in eastern Tibetan tribes. From 
this perspective, those eastern tribes in which set up the Weisuo should be regarded as an internal tributary of the Ming court, while central Tibet still maintained its independence. In the Qing Dynasty, the status of Tibet gradually changed according to the degree of intervention that the Qing court imposed on Tibet. At the beginning of the Qing Dynasty, Tibet continued to maintain its independence as the Qing's influence there was too weak to interfere with the administration in Tibet. But with the Qing's deeper involvement in Tibetan affairs, Tibet lost its independence and became an external tributary of the Qing Dynasty. The two imperial decrees issued by Emperor Qianlong completely terminated the independence of Tibet as they established the Qing's direct control over Tibet in the form of imperial law. Thus, Tibet had become an internal tributary within the boundaries of the Qing Dynasty. 


\section{Chapter 3 The Status of Tibet Before the Twentieth Century - From the Perspective of Unequal Treaty System}

\section{Introduction}

The previous chapter discussed how the pre-nineteenth century development of Tibet's status from an independent State to an external tributary of the Yuan and eventually an internal tributary of the Qing under the framework of the tribute system. In the midnineteenth century, the Qing Empire's defeat in the Opium War forced China to learn about modern international relations and international law. ${ }^{1}$ From then on, China concluded a great number of 'unequal treaties' with Western powers which broke the tribute system and produced a new system in international relations - the Unequal Treaty System. ${ }^{2}$ This Unequal Treaty System, contrary to the normal principles of international intercourse, was an embodiment of encroachment on China's sovereignty, as the treaties under the coercion gave Western powers unilateral privileges. Therefore, the validity of these unequal treaties was questioned by revolutionaries in the late Qing period. ${ }^{3}$ With regard to Tibet, following Britain's growing interest in developing Tibet as a trade route to China proper from India, Tibet for the first time became a subject on the negotiating table between imperial China and the Western powers. During the nineteenth century, Britain concluded three Tibet-related treaties with China by use of force or coercion. An analysis of the context and provisions of these treaties provides an opportunity to observe how Britain and China regarded the status of Tibet under the Unequal Treaty System. However, this assumption is only based on the premise that these treaties were valid in international law at that time because it would be pointless

\footnotetext{
${ }^{1}$ In June, 1840, the British government used the opium issue as an excuse to wage a war against the Qing government. As a result, China was defeated and was forced to sign the Treaty of Nanking on 29 August 1842 and the Treaty of the Bogue on 8 October 1943.

${ }^{2}$ See Chung, Tan, The Unequal Treaty System: Infrastructure of Irresponsible Imperialism, China Report, XVII, 5, 1981, pp 1-31; John K. Fairbank, "The creation of the treaty system" in the Cambridge History of China, Vol. X, Cambridge University Press, 1978, pp 213-63.

${ }^{3}$ For example, in 1906, Wang Jinwei (汪精卫) once argued that “ it is the new government's responsibilities to change the weak diplomacy of the Qing and to withdraw or modify all unequal treaties that concluded with the Western powers.” See Wang Jinwei, Refuting the revolution will incur Western powers to divide China (驳革命可 以召瓜分说), in Selected Works of Public Opinion in the Ten Years Before the 1911 Revolution (辛亥革命前十年 间时论选集), Sanlian Press, 1963, p 461.
} 
to discuss the status of Tibet implied in these treaties if they were invalid. To this end, this chapter first aims to explore the validity of unequal treaties signed between China and the Western powers in the nineteenth century and then discusses how the Tibet issue was internationalised and the position held by Britain on the status of Tibet from these Tibet-related treaties. The relevance of this chapter lies in giving background information about the origin of the controversy between China and Britain over the status of Tibet as well as revealing Britain's early position on this issue. As this chapter tries to discuss the status of Tibet against the background of the Unequal Treaty System, three early Tibet-related treaties signed between China and Britain before the twentieth century serve as primary sources. Their context and contents are analysed to reveal how the British regarded Sino-Tibetan relations when they first got involved in Tibet affairs. Furthermore, the manuscripts and archives serve as secondary sources. They describe China's acceptance of modern international law and the British involvement in Tibet at its early stage.

This chapter contains two parts. The first part focuses on the collisions between the tribute system and modern international law. It first introduces the process of China's acceptance of the modern international law system under the encroachment of Western powers since the 1840s. From then on, China began to deal with its diplomatic affairs under the system of international law rather than the tribute system. With regard to Tibet, this transition provided a new theoretical framework to observe its status from the $1840 \mathrm{~s}$ to the 1950s. The discussion then moves to the validity of treaties concluded between China and the Western powers through the use of force and coercion by the latter. This is important because almost all Tibet-related treaties were more or less signed by China under the use of force or coercion. Therefore, the discussion of the validity of unequal treaties not only constitutes a premise for the treaty-based study in this chapter but also lays foundation for the later study of Tibet-related treaties signed in the twentieth century. The second part of this chapter gives a brief introduction to Britain's early involvement in Tibet in order to understand the background of the later Tibet-related treaties. The discussion then moves to examine the status of Tibet pursuant to the SinoBritish treaties. And the implicit attitude of China and Britain towards Tibet is inferred by analysing the context and the terms of these treaties. 


\subsection{China and The Unequal Treaty System}

As China's fundamental system to handle its foreign relations, the tribute system had effectively operated until the mid-nineteenth century. However, China's defeat in the Opium War marked the decline of the tribute system and forced China to learn about modern international relations. This section aims to introduce how imperial China began to replace its tribute system with a modern international legal order. This process makes it possible to observe and explain the interactions between China and the Western powers on the Tibet issue within the framework of international legal discourse. In addition, the discussion on the validity of unequal treaties concluded between China and the Western powers is directly relevant to the early Tibet-related treaties because their validity constitutes a premise for analysing the status of Tibet based on their provisions.

\subsubsection{China's Approach to International Law Since the 1840s}

The 1842 Treaty of Nanking between China and Britain was the first unequal treaty in the modern diplomatic history of China, ${ }^{4}$ however, China's practice of making treaties can be traced back to the 17th century when the Qing Government and Russia concluded the 1689 Treaty of Nerchinsk and the 1727 Treaty of Kiakhta. ${ }^{5}$ Although 'no formal procedural aspects of international law as it was practiced in Europe at this time were mentioned in these treaties', ${ }^{6}$ the contracting parties were on an equal footing and the provisions of the treaties were also equal and reciprocal. However, the Treaty of Nanking initiated a great number of unequal treaties which severely challenged the tribute system and produced a new system - the Unequal Treaty System. ${ }^{7}$ Contrary to the principle of sovereign equality pursued among Western powers, these treaties were not only concluded under the coercion of armed force but also gave Western powers unilateral privileges in many fields, such as extraterritorial jurisdiction, one-sided most

\footnotetext{
${ }^{4}$ With regard to the 1842 Treaty of Nanking, see Mayers, William Frederick, Treaties between the Empire of China and foreign powers, Shanghai: North-China Herald Office, 1902, p 1.

${ }^{5}$ Phil C. W. Chan, China, State Sovereignty and International Legal Order, Brill, 2015, p 65. See also Rune Svarverud, 'Re-Constructing East Asia: International Law as Inter-Cultural Process in Late Qing China', 12 Inter-Asia Cultural Studies ,2011, pp 306-10.

${ }^{6}$ Phil C. W. Chan, ibid.

${ }^{7}$ Yang Zewei, Western International Law and China's Confucianism in the 19th Century -Collision and Integration, Journal of the History of International Law, Vol. 13, 2011, p 298.
} 
favoured-nation treatment, leased territories, foreign troops station and navigation rights on coastal and inland waters. The Unequal Treaty System was by its nature a privilege of 'quasi-sovereignty' exercised by Western powers over China. Compared with the international law applicable among Western powers, non-Christian states were in fact brought into a legal order that emphasised the law of the jungle in the relationship with Western powers. As Prof. Cheng Ti-chiang pointed out: 'Western powers suppressed China first with force, then with unequal treaties, which governed all relations with China, leaving no space for the application of international law at all' ${ }^{8}$ This argument to some degree reflected the reality at that time. However, China did not lack the initiative to learn and apply international law in its foreign relations.

In 1864, William Martin, an American missionary, translated Henry Wheaton's Elements of International Law into Chinese and titled it Wanguo Gongfa (Public Law of All Nations). It was the first book in Chinese which systematically introduced international law to China. ${ }^{9}$ Through the study of Wanguo Gongfa, China began to take the first step to accept modern international relations and regarded it as a 'weapon' against the illegal requests of 'wild' foreign consuls. ${ }^{10}$ For the convenience of dealing with Western countries, the Qing Government also reformed its bureaucracy by establishing the Tsungli Yamen, the first diplomatic department in Chinese history. ${ }^{11}$ Before the establishment of the Tsungli Yamen, the foreign relations of the Qing Empire were mainly conducted by the Libu (the Ministry of Rites) in accordance with the principles of the tribute system. Before the Opium War, the Qing strictly restricted trade with Western countries at the harbour of Guangzhou. ${ }^{12}$ The Western powers were unwilling to accept the inequality under the tribute system, but instead of dealing with arrogant and inefficient local officials of Guangzhou, they preferred to establish direct communication with the central government. The Qing Government, in response to the Treaty of Tientsin in 1858 which allowed Western powers to set up legations in Beijing, faced a new diplomatic situation and accordingly established a new diplomatic institution. The establishment of Tsungli Yamen made it possible for foreign diplomats

\footnotetext{
${ }^{8}$ Wang Tieya, International Law in China: Historical and Contemporary Perspectives, Recueil des Cours, 1990, II, p. 258.

${ }^{9}$ Yang Zewei (杨泽伟), Study on the History of International Law (国际法史论), 2nd ed., Higher Education Press (高等教育出版社), 2011, p. 338 .

${ }^{10}$ Immanuel C.Y. Hsü, China's Entrance into the Family of Nations: The Diplomatic Phase, 1858- 1880, Harvard University Press, 1960, p 145.

${ }^{11}$ Shin Kawashima, China, in the oxford handbook of history of international law, the oxford university press, 2012, p 460 .

${ }^{12}$ Guangzhou, also known as Canton, is the capital and most populous city of the province of Guangdong in southern China.
} 
to communicate directly with the central government. On the basis of the Tsungli Yamen, the Qing set up the Ministry of Foreign Affairs in 1901. From then on, China began to defend its interests by applying international law. In 1864, Prussian minister Guido von Rehfues led a warship to China. Because Prussia had declared war on Denmark at that time, Rehfues seized three Danish commercial ships at Dagu, a Chinese port. The Tsungli Yamen protested that Dagu was in internal waters under Chinese jurisdiction, thus Prussia's action violated international law. When China pointed out the illegality of Prussia and threatened not to recognise the Prussian ambassador, Prussia released the Danish ships and made compensation to these ships. ${ }^{13}$ In 1867, the Qing Government appointed Anson Burlingame, a former American minister to China, as the envoy to the United States and later appointed him to lead a delegation to visit the major European States. ${ }^{14}$ In 1874, the Qing Government signed a commercial treaty with Peru to protect the interest of Chinese labours in Peru, and there were some mutual mostfavoured-nation treatment clauses in this treaty. ${ }^{15}$ In 1899 and 1907, the Qing Government attended the two Hague Peace Conferences and signed the Hague conventions. ${ }^{16}$

Although international law to some extent safeguarded China's interests from Western encroachment, the Qing's view on international law was complicated. The attitudes of officials and literati towards international law could generally be divided into two schools. One school, headed by Li Hongzhang (李鸿章), held that international law was useful and could be relied on to maintain national security and world peace. As Cranmer-Byng argued about the Qing's attitude towards unequal treaties, 'throughout the Chinese documents of the period from the 1840s into the 1880s these treaties were regarded not only as concessions extracted by force but also as traditional methods of controlling those who did not accept the Chinese world view'. ${ }^{17}$ Li's view approximately reflected the mainstream view on international law. The other school, represented by Zheng Guanying (郑观应) and Xue Fucheng (薛福成), who had no confidence in international law, held that although international law could be helpful to

\footnotetext{
${ }^{13}$ Tongzhi Chao Chouban Yiwu Shimo (同治朝筹办夷务始末, Complete Record of the Management of Barbarian Affairs: Emperor Tongzhi) vol 26, Zhonghua Shuju Press (中华书局), 2008, p 29-36.

${ }^{14}$ John Schrecker, For the Equality of Men - For the Equality of Nations: Anson Burlingame and China's First Embassy to the United States, 1868, Journal of American-East Asian Relations 17 (2010), p 9-34.

${ }^{15}$ Yang Zewei, supra n. 9, p 301.

${ }^{16}$ Chi-Hua Tang, China-Europe, in the oxford handbook of history of international law, the oxford university press, 2012, p 711.

${ }^{17}$ Amy Kellam, Foreign Devils: Law's Imperial Discourse and the Status of Tibet, the $\mathrm{PhD}$ thesis submitted for the Department of Law, SOAS, University of London, 2013, p 64.
} 
some extent, China could not rely on it if the country was not powerful and prosperous. ${ }^{18}$ To the Qing Empire, bringing international law into China's diplomatic practice did not mean that the tribute system was replaced by the international legal regime in its foreign relations. The Qing Empire had consistently maintained its relations with surrounding countries within the framework of the tribute system until its last external tributary-Korea-was occupied by Japan in the Sino-Japanese War of 1894. The Qing Empire demonstrated adaptability between the Unequal Treaty System and the tribute system, although these two views of world order collided with each other.

Modern international law, which was introduced into China since the 1840 s, inevitably collided and coexisted with the tribute system. China, to some extent, defended its national interests by applying international law in dealing with the Western Powers, even though many Chinese believed that China was excluded from the international legal system among 'Christian' States based on the principle of sovereign equality because the only law applied to China was unequal treaties. However, the signing of a great number of unequal treaties under force and coercion had undoubtedly damaged China's sovereignty in this process. The following section focuses on an examination of the validity of the unequal treaties that constituted the pillars of the Unequal Treaty System in order to determine whether the early Tibet-related treaties could be regarded as reliable legal resources to examine the status of Tibet.

3.1.2 The Validity of Treaties Between China and Western Powers in the Nineteenth Century

Throughout the nineteenth century, European Powers concluded a great number of agreements with the 'native' people in Africa, the South Pacific and Asia, whether by means of force or equality. However, whether these agreements were treaties and whether they were valid in international law roused debate among international jurists of the nineteenth century. As for the case of Tibet, China was forced to sign a great number of Tibet-related treaties with Western powers after the Opium War. These treaties to some extent constitute the legal basis for exploring the status of Tibet; however, this can only be established under the premise that these 'unequal' treaties were valid in international law at that time. Therefore, this section discusses whether

\footnotetext{
${ }^{18}$ Yang Zewei, supra n. 9, pp. 346-347.
} 
China was eligible to conclude treaties with the Western States in the nineteenth century and the validity of treaties concluded under force and coercion.

According to international law of the nineteenth century, a treaty is only valid if made between the subjects of international law that are 'civilised' States; ${ }^{19}$ however, not all political entities could meet the criteria of a 'State', and "civilised" State is obviously a higher standard. Furthermore, the principle of equality of sovereignty, as an essential spirit of the international legal system, also made the legality of these treaties uncertain as they were concluded on the basis of inequality. It was Grotius who first put forward the concept of equality of sovereignty and called for the recognition of the indigenous sovereignty of non-Western people. He confirmed the possibility of entering into treaties with them, as their adherence to a different faith did not preclude their abilities to exercise rights and duties according to natural law. ${ }^{20}$ Pufendorf went further and explained that all persons in a state of nature are equal, and since international persons are in a state of nature, they must likewise be equal. ${ }^{21}$ With regard to the practice of sovereign equality in Europe, Talleyrand, the French Foreign Minister, advocated at the 1814 Congress of Vienna that the rights of small States should be duly respected during the negotiation. ${ }^{22}$ This shows that the principle of equality already had to some extent already won the support among the European States in the nineteenth century. However, the question of whether the European States should conclude treaties with nonEuropean people on the basis of equality roused debate among scholars.

On the question of the eligibility of contracting parties, according to classical theory of international law, treaties are only valid if made between the subjects of international law, which mainly referred to States before the mid-nineteenth century. ${ }^{23}$ With regard to the criteria of being a State, Henry Wheaton pointed out that one of the preconditions for the recognition of a State is that 'it has a form of civilization which renders it able to apply the rules of that law, and it must be in communications with the States already

\footnotetext{
${ }^{19}$ Oppenheim, for example, suggests that 'In order for a State to become a fully functioning member of the international community it must, inter alia, be a civilized State which is in constant intercourse with members of the Family of Nations.' See Gerrit W Gong, Standard of 'Civilization' in International Society, Oxford: Clarendon Press, 1984, p30.

${ }^{20}$ Inge Van Hulle, Grotius, Informal Empire and the Conclusion of Unequal Treaties, Grotiana 37 (2016) pp 43-60.

${ }^{21}$ Pufendorf, De jure Naturae et Gentium Libre octo, Classics of International Law, Oxford: Clarendon Press, 1934, pp 330-45. Also see Fariborz Nozari, Unequal Treaties in International Law, the Doctoral Thesis of the Law School of the University of Stockholm,1971, p 62.

${ }^{22}$ Fariborz Nozari, pp 68-69. See also Baker. P. J, the Doctrine of Legal Equality of States, British Year Book of International Law, 1923-1924, pp 1-20.

${ }^{23}$ Although international organizations are accepted as subjects of international law, the first and oldest intergovernmental organization is the International Telecommunication Union which founded in 1865.
} 
enjoying it'. ${ }^{24}$ Oppenheim explicitly asserted that for a 'State' to become a fully functioning member of the international community, it must, inter alia, 'be a civilised State which is in constant intercourse with members of the Family of Nations.' ${ }^{25}$ Westlake further clarified the scope of application of international law, arguing that 'the international society to which we belong, and of which what we know as international law is the body of rules comprises - First, all European States ... Secondly, all American States ... Thirdly, a few Christian States in other parts of the world ... ${ }^{26}$ According to the above view, international law was only applied to 'civilised' States or, more specifically, Christian States. In this sense, any agreements made by the European States with 'uncivilised people could not be enforced as valid treaties in international law because the latter were not the subjects of international law, nor did the European States owe any duties under such agreements. ${ }^{27}$

In the twentieth century, some writers argued that the distinction between 'civilised' and 'uncivilised' was an exclusive development in the nineteenth century known as 'positivism', which ignored the arguments of early writers such as Bynkershoek. ${ }^{28}$ Bynkershoek pointed out that 'the law of nations is that which is observed, in accordance with the light of reason, between nations, if not among all, at least certainly among the greater part [of the nations of the world], and those the most civilised., ${ }^{29}$ This view clearly implies countries outside of Europe could be eligible to become the subject of international law. Even Westlake, who thought the standard of civilisation was high and mostly existed in the Christian States, also agreed that 'a government after the manner of Asiatic empire...would be sufficient'. ${ }^{30}$ But could China be considered as a subject of international law during the nineteenth century? The Institut de Droit International seemed to give a positive answer in 1879. On the question of applying

\footnotetext{
${ }^{24}$ Henry Wheaton, Elements of International Law 6th edition, vol 1, London: Stevens \& Sons Ltd, 1929, p 30.

${ }^{25}$ Gerrit W Gong, Standard of 'Civilization' in International Society, Oxford: Clarendon Press, 1984, p30. Also see Tom Bennion, Treaty-Making in the Pacific in the Nineteenth Century and the Treaty of Waitangi, Victoria University of Wellington Law Review 35, 2004, p 167.

${ }^{26}$ John Westlake, the Principles of International Law, Cambridge University Press, 1894, p 81.

${ }^{27}$ Tom Bennion, supra n.25, p 168.

${ }^{28}$ With regard to the situation in Africa, Alexandrowicz said: "the Europeans arriving in Africa at first brought with them a law of nations based on the natural law ideology which started fading out in the nineteenth century, giving way to positivism. Positivism discarded some of the fundamental qualities of the classic law of nations, particularly the principle of universality of the Family of Nations irrespective of area, race, color, and continent ... International law shrank into a Euro-centric system which imposed on extra-European countries its own ideas ... It also discriminated against non-European civilizations and thus ran on parallel lines with colonialism as a political trend." See Charles Henry Alexandrowicz, the European-African Confrontation - A Study in Treaty Making, Leiden: Sijthoff, 1973, p 6.

${ }^{29}$ As quoted in Henry Wheaton's Elements of International Law, 8th edition, Boston, Little Brown and Company, 1866, p 18. See also Tom Bennion, supra n.25, p 169.

${ }^{30}$ John Westlake, p 141.
} 
international law to the East, the rapporteur Sir Travers Twiss claimed that "people from the Ottoman Empire, Persia, China and Japan are different from people of other uncivilised countries. Relations with Eastern countries differ depending on the level of civilisation. ${ }^{31}$ With respect to China and Japan, he further claimed that 'both countries were aware of their obligations toward foreign nationals and individuals, and this awareness is essentially the same as the European people's awareness of the basic principle of European international law - The principle that no authority can elude the obligations of a treaty without the other party's agreement.' 32 Therefore, China could hardly be excluded from the community of civilisation and its eligibility for making treaties with the European States was confirmed by the authoritative academy in the nineteenth century.

The validity of the treaties that were signed under force or coercion between the Qing and the Western powers was later questioned by the Republic of China, the successor of the Qing, as these treaties were products of wars. These treaties neither followed the light of equality and voluntariness nor were they mutually reciprocal. As Talalayev wrote, '[these treaties], in a greater or lesser degree, infringe the sovereignty of states, establishing control over legal relationships which are within the domestic jurisdiction of states and people. ${ }^{33}$ Similarly, Lester argued, 'the attacks on the validity of those treaties seem to stem from hostility to the situation in which unequal bargaining power enables the stronger contracting party to induce the weak party to bind itself, contrary to its interests, and to general principles of justice. ${ }^{34}$ Although Article 52 of the Vienna Convention on the Law of Treaties (VCLT) stipulates that a treaty is void if its conclusion has been procured by the threat or use of force, ${ }^{35}$ it did not necessarily reflect the theories and State practice in the nineteenth century.

\footnotetext{
${ }^{31}$ On the application of international law to the east, the rapporteur Sir Travers Twiss stated:" People from Ottoman Empire, Persia, China and Japan are different from people of other uncivilized countries. Relations with Eastern countries differ depending on the level of civilization." With respect to China and Japan, he stated: "Both countries were aware of their obligations toward foreign nationals and individuals, and this awareness is essentially the same as the European people's awareness of the basic principle of European international law - The principle that no authority can elude the obligations of a treaty without the other party's agreement. See Travers Twiss, 'Rapport', 34 Annuaire Institut de Droit International (1879-1880) pp. 301-05.

${ }^{32}$ Ibid.

${ }^{33}$ Talalayev, A. N., Unequal Treaties as a Model of Prolonging the Colonial Dependence of the New States of Asia, and Africa, Sovietskii Ezhegodnik Mezhdynarodnogo Prava, 1961, p 170. Also see Fariborz Nozari, supra n.21, p 91.

${ }^{34}$ Lester, A., Bizerta and the Unequal Treaty Theory, the International and Comparative Law Quarterly, 1962, p 850.

${ }^{35}$ The Yearbook of the International Law Commission, vol 2, 1966, p 245-47. See also Articles 52 of the Convention on the Law of Treaties.
} 
The origin of Article 52 could be traced back to 1951 when James Brierly, the Special Rapporteur of the International Law Commission, submitted two proposals by Bluntschli and Fiore on the effects of threats or violence on consent to enter into a treaty. These two proposals written in the second half of the nineteenth century probably reflected the views of international legal jurists on the circumstances under which the treaty was invalid. Bluntschli argued that free will did not exist if the representatives of the State were 'subjected to violence or grave and immediate threats'. ${ }^{36}$ Fiore considered that coercion was a ground of invalidity when the State was subjected to 'physical violence' or when its representatives were led to act based on 'external constraint'. ${ }^{37}$ Though there was no consensus on whether the use of force or coercion against a State would result in the invalidation of the treaty, the two proposals both emphasised that the coercion of representatives of a State would constitute a justification for the invalidity of a treaty. In other words, the unequal treaties that were concluded by use of force or coercion against a State might not necessarily invalid unless the representatives of that State were subjected to force or coercion during the negotiation. As for Britain's treaty-making practice, Arnold McNair observed: 'it is believed that the United Kingdom has at no time expressed any dissent from the current doctrine that a treaty is not rendered ipso facto void, and cannot be repudiated by one of the parties, by reason of the fact that such a party was coerced by the other party into concluding it, whether that coercion is applied at the time of signature or of ratification or at both times. ${ }^{38}$ Before the First World War, treaties obtained by threat or use of force against a state were considered 'morally questionable' but not illegal. ${ }^{39}$ Because war was a permissible means of settling international disputes, the existence of coercion would not automatically invalidate a treaty as it was necessary and desirable for the termination of wars and the conclusion of peace treaties. ${ }^{40}$

As for the treaties between China and the Western powers, now that China was considered as a member of international community during the nineteenth century, its capacity to enter into treaties with the Western States could not be deprived according

\footnotetext{
${ }^{36}$ ILC, 'Report on the Law of Treaties by J.L. Brierly, Special Rapporteur' (14 April 1950) UN Doc A/CN.4/23. Recite from Guilherme Del Negro, the validity of treaties concluded under coercion of the state: sketching a TWAIL critique, European Journal of Legal Studies, Vol. 10, 2017, pp 43-4.

${ }^{37}$ Ibid.

${ }^{38}$ A. McNair, The Law of Treaties: British Practice and Opinions, Oxford University Press, 1938, p 129.

${ }^{39}$ Omar M. Dajani, Contractualism in the Law of Treaties, Michigan Journal of International Law, Vol. 34, 2012, p 35.

${ }^{40}$ Fariborz Nozari, supra n.21, p 46. See also Matthew Craven, What Happened to Unequal Treaties? The Continuities of Informal Empire, Nordic Journal of International Law 74, 2005, pp 335-82.
} 
to international law at that time. Although China was forced to sign a great number of unequal treaties under coercion or the use of force, the validity of these treaties should be admitted because coercion was to some extent tolerable in the eyes of international law. To China, the binding force of these unequal treaties was recognized by the Chinese diplomats. For example, Yi Xin (奕䜣), the head of the newly formed Tsungli Yamen, insisted 'as long as we signed these treaties, we must abide by it' ${ }^{41}$ Similarly, Guo Songtao (郭嵩奉) explained that China had the right to refuse the Western States' illegal demands, but China must respect treaties. ${ }^{42}$ From this perspective, those Tibet-related treaties that were concluded between the Qing and the Western powers in the nineteenth century were valid under international law. After making this point clear, the following part analyses the status of Tibet based on the early British involvement in this region and on the basis of three Tibet-related treaties concluded between the Qing and Great Britain in the second half of the nineteenth century.

\subsection{The Status of Tibet in Sino-British Negotiations}

Before the nineteenth century, Tibet had long been considered to be an isolated land in the Western discourse as almost all attempts by the Western missionaries to enter Tibet failed. However, the British East India Company had been anxious to develop a trade relationship with Tibet since the eighteenth century. With the expansion of the British influence in the Himalayas, the East India Company decided to put the idea into practice. This section discusses early British involvement in Tibet and analyses the status of Tibet from a reading of Sino-British treaties on Tibet before the twentieth century.

\subsubsection{Early British Involvement in Tibet}

In 1772, a conflict between Bhutan and Cooch Behar broke out over the succession of the Cooch Behar throne, which provided Warren Hastings, the first Governor-General of India, with a starting point for Anglo-Tibetan relations. ${ }^{43}$ With the help of the British

\footnotetext{
${ }^{41}$ Beginning and End of the Management of Barbarian Affairs, Tongzhi Period, Vol. 50, p.50. Recite from Yang Zewei, supra n. 9, p 302.

${ }^{42}$ Ibid., p 303.

${ }^{43}$ Cooch Behar was a princely state ruled by Rajbanshi clans during the British India. The state was placed under the Bengal States Agency, part of the Eastern States Agency of the Bengal Presidency. It is located south of the 
army, the forces of Cooch Behar gained a series of victories over Bhutan. However, it incurred the alarm of the Gurkhas, who were reluctant to see a British control over Bhutan. Consequently, the Gurkhas sent representatives to Tibet to inform the Sixth Panchen Lama, the other great Buddhist leader of the Geluk sect in Shigatse, of the possible British occupation of Bhutan. ${ }^{44}$ In response, the Panchen Lama wrote a letter to Hastings on behalf of the Bhutanese. ${ }^{45}$ Hastings hence regarded it as an opportunity to dispatch a mission to the Panchen Lama. With the task of investigating the markets and resources of Tibet and exploring the possibility of using the influence of Tibet to facilitate British trade and diplomacy with China, the mission led by George Bogle arrived in Shigatse in $1774 .{ }^{46}$ Bogle visited the Panchen Lama on many occasions and established a firm friendship with him, but he was unable to visit Lhasa. What was worse, his presence in Shigatse aroused the suspicion of the Tibetan local government and the Amban in Lhasa. ${ }^{47}$ Bogle's mission did little to open any trade route between India and Tibet, but the Panchen Lama promised Bogle that he would write to an influential Lama in Peking so that the emperor might think about the possibility for a British envoy to make his way through Tibet to the Chinese capital. ${ }^{48}$

In the years following Bogle's return, letters continued to pass between the Panchen Lama and Bogle and Hastings, and the Lama often reminded them that the Qing Government and the Tibetan local government shared a hostile view on the British. Concerning the Sino-Tibetan relations, the Lama once wrote: 'as this country [Tibet] is under the absolute sovereignty of the Emperor of China, who maintains an active and unrelaxed control over all its affairs, and as the forming of any connection of friendship with Foreign powers is contrary to its pleasure, it will frequently be out of my power to dispatch any messengers to you. ${ }^{49}$ Subsequently, the Panchen Lama again declined the request of Hastings to dispatch another mission to Shigatse because of the presence of

\footnotetext{
Himalayan kingdom of Bhutan. See Alastair Lamb, British India and Tibet 1766-1910, Routledge \& Kegan Paul Press, 1986, pp 6-7.

${ }^{44}$ At that time, Bhutan had not only owned political allegiance to Tibet, but also maintained a close commercial relationship with Tibet.

${ }^{45}$ His letter to Hastings in March 1774, and in the letter, he recognized the wrong action of Bhutanese ruler, and indicated his influence over the ruler of Bhutan and his ability to mediate between the warring factions at the frontier of Tibet. See Tansen Sen, India, China, and the World: A Connected History, Rowman \& Littlefield, 2017, p 246.

${ }^{46}$ Markham, Sir C., Narratives of the Mission of George Bogle to Tibet, and of the Journey of Thomas Manning to Lhasa, London 1876, pp 5-8.

${ }^{47}$ Ibid, pp 150-151.

${ }^{48}$ Alastair Lamb, p 10.

${ }^{49}$ Markham, p 151.
} 
a Chinese official there, and he did not wish to openly challenge the authority of the Chinese. ${ }^{50}$

As mentioned in the previous chapter, from 1781 to 1791, the Gurkhas twice invaded Tibet and occupied several points across the Tibetan border. ${ }^{51}$ The Qing emperor then sent a strong army to defeat the Gurkhas and drive them to the very neighbourhood of Kathmandu. During the Qing-Gurkha War, the British East India Company received letters both from the Gurkhas and the Tibetans. The former sought the Company's assistance and the latter requested British neutrality. The Company adopted a policy of playing one side against the other, and mediation by the Company was offered to both parties. While in secret, the representative of the Company seemed to have hinted that it might supply armed help to the Gurkhas in return for a commercial treaty to open Nepal-British trade. However, after the treaty was signed in 1792, the Gurkhas felt that they had been tricked as they found that no help beyond the Company's mediation would be forthcoming. The Chinese and Tibetans seemed to have had a definite impression that the British had sent troops to help the Gurkhas against them. ${ }^{52}$ It was believed that this sceptical attitude partly led to the failure of the Macartney's mission to establish formal diplomatic relations with the Qing. ${ }^{53}$ In 1793, to improve trade conditions with China, a British mission led by Lord Macartney arrived in Peking and met the Emperor Qianlong. Unfortunately, his mission coincided with these events in Tibet, and he was surprised to hear the news from the Chinese that they were furious at the way in which the British had fought against them in the recent Qing-Gurkha war. Although he denied the charge in his most decisive manner, Macartney realised that the Chinese in Peking, including the Emperor Qianlong, genuinely believed that the British had opposed China in the recent war. It was impossible for him to make any progress in either persuading the emperor to lossen the restrictions on Anglo-Chinese trade or establish formal diplomatic relations with the Qing. With the benefit of hindsight, the real reason behind the failure of the Macartney's mission was the incompatibility between the tribute system and modern international relations. Following the spirit of the tribute system, one cannot expect that the Chinese emperor could tolerate the relations with 'barbarians' based on equality. The failure of Macartney demonstrated

\footnotetext{
${ }^{50}$ The presence of a Chinese ambassador at Tashilhunpo made it impossible for Hamilton to come to see the Panchen Lama. Lhasa, moreover, would certainly object strongly to another Englishman following so closely in Bogle's footsteps, see Papers of George Bogle: Hamilton to Bogle, 30 May. The document is in the India Office Library.

${ }^{51}$ See note 78 in 2.3 .3 of the chapter 2.

${ }^{52}$ Aitchison, C. U., Collection of Treaties, Engagements and Sanads, vol 14, Calcutta 1929-31, p 56.

${ }^{53}$ Alastair Lamb, supra n. 43, p 21-3.
} 
the Emperor Qianlong's ambition to put Tibet under his direct control and any potential foreign involvement in Tibet would result in his displeasure.

During the second half of the eighteenth century, the British East India Company became aware of the strategic importance of Tibet in securing the northern frontier of India and facilitating trade with China proper. In this context, the Company sent Bogle to the Panchen Lama and developed a friendship with the Lama in 1774. Subsequently, the British East India Company played an ambiguous role in the Qing-Gurkha war, which raised the suspicions of in the Chinese and Tibetans about the intentions of the Company in Tibet. It can be seen from the above activities that the British in India tried to avoid direct involvement in Tibetan affairs. Although aware of the presence and influence of the Qing in Tibet, the Company did not take a definite position on the SinoTibetan relations in their early involvement. That was not the end of the story because in the second half of the nineteenth century, the British Indian authority had significantly accelerated its intervention in Tibetan affairs. The following section mainly focuses on revealing the status of Tibet behind the Tibet-related treaties between China and Britain.

\subsubsection{Sino-British Conventions on Tibet in the Nineteenth Century}

In order to expand its influence around the Himalayas, Britain became the first and only Western State to intervene in Tibetan affairs during the second half of the nineteenth century. In this process, Britain signed three Tibet-related treaties with China. They were: The Separate Article in Chefoo Convention of 1876; the Convention Relating Burma and Tibet of 1886 and the Convention Between Great Britain and China Relating to Sikkim and Tibet of 1890. By analysing the background, the subjects and the provisions of these treaties, this section tries to unfold the British position on the status of Tibet before the twentieth century.

\section{(1) The Separate Article in Chefoo Convention of 1876}

As mentioned earlier, long before Britain obtained the treaty ports in China through the Treaty of Nanking, some investigations had already been made by the British to explore the possibilities of facilitating trade with China by land routes from British India to 
China proper. Geographically, Chinese territory is adjacent to British India at three points, and one of the points, Yunnan Province, had a common frontier with Lower Burma, which had been annexed by the British. ${ }^{54}$ In 1874, an exploratory mission was instructed to cross the Burma-Yunnan border. While travelling in Yunnan in 1875, A. R. Margary, an interpreter for the mission, was murdered by local tribesmen, and the local government was under suspicion of having some complicity in his death. ${ }^{55}$ To solve the incident, Wade, the British minister in China, discussed the aftermath with the Chinese representative Li Hongzhang at the city of Yantai (Chefoo) in 1876. During the negotiation, Wade requested the Tsungli Yamen to agree to issue passports to a British expedition from India to Tibet. The Tsungli Yamen was not initially prepared to accept the Tibet clause for fear of another Margary affair, but Li Hongzhang eventually agreed to add this clause after Wade understood that the issuance of passports was made based on the opinion of Chinese Amban in Lhasa. Therefore, the negotiations ended up with the conclusion of the Chefoo Convention, ${ }^{56}$ and the Tibet-related article was stipulated in its Separate Article as follows:

'Her Majesty's Government having it in contemplation to send a mission of exploration next year, by way of Peking, through Kansuh and Koknor, or by way of Sichuan to Tibet, and thence to India, the Zongli Yamen, having due regard to the circumstances, will, when the time arrives, issue the necessary passports, and will address letters to the High Provincial Authorities and the Residents (Amban) in Tibet. If the Mission should not be sent by these routes but should be proceeding across the Indian frontier to Tibet, the Zongli Yamen, on receipt of a communication to that effect from the British Minister, will write to the Chinese Resident in Tibet, and the Resident, with due regard to the

\footnotetext{
${ }^{54}$ Historically, Lower Burma referred to the part of Burma annexed by the British Empire after the end of the Second Anglo-Burmese War in 1852, plus the former kingdom of Arakan and the territory of Tenasserim which the British had taken control of in 1826 through the Treaty of Yandabo. See Mya Than, Myanmar's External Trade: An Overview in the Southeast Asian Context, Institute of Southeast Asian,1992, p 7. Apart from the Burma-Yunnan road, the other two points are: along the Himalayas India territory marched with that of Tibet; and through Kashmir and across the passes of the Karakoram lay the road to Kashgar, Khotan, Yarkand and other markets in Chinese Turkestan. See Alastair Lamb, supra n. 43, p 114.

${ }^{55}$ In 1867 the British gained the right to station a commercial agent at Bhamo in Myanmar, from which they could explore the Irrawaddy River up to the Yunnan border. See https://www.britannica.com/place/China/The-first-OpiumWar-and-its-aftermath\#ref590560.

${ }^{56}$ The Chefoo convention consisted of sixteen articles and was divided into three sections. The first section dealt with the resolution of the Margary Affair, calling for the punishment of the people implicated in the murder of Augustus Raymond Margary the year before and stipulating that an indemnity be paid to Margary's relatives. The second section dealt with official intercourse between the two empires and specified the extraterritorial privileges of British subjects in China. The final section dealt with trade, prohibiting the levying of the Lijin in the treaty ports, outlawing other forms of taxes on foreign goods, and opening a number of new treaty ports.
} 
circumstances, will send officers to take care of the Mission, and passports for the Mission will be issued by the Zongli Yamen, that its passage be not obstructed' ${ }^{57}$

Under the provisions of the Separate Article, the British obtained the right to send a mission to Lhasa. For the first time, Tibet had formally become the object referred to in a Sino-foreign treaty, albeit with an undefined meaning of passport therein. According to Kenneth Diplock, in English law, the expression 'passport' is used as a generic term for any document issued to enable travel or to facilitate a journey from one place to another, whether within the realm or to foreign lands. ${ }^{58}$ In general, passports are official documents issued by national authorities of the bearer to offer some proof of identity and nationality and enable the crossing of international boundaries. However, under some circumstance, a government can also issue passports to foreigners as a permit to allow the latter to enter some regions of the state. From this perspective, the passports of the latter case were more like a special visa. With regard to the case of China, the 1858 Sino-Anglo Treaty of Tien-Tsin first stipulated that British subjects were authorised to travel to all parts of the interior [of China] under passports issued by their Consuls, and countersigned by the local authorities. In some cases, under the request of foreign legation, some Chinese ministry also issued special passports for foreigners to enter the peripheral areas of the Qing Empire. For example, the travelling passports for foreigners to Mongolia were issued by Lifan Yuan with Mongolian language. ${ }^{59}$ This example to some extent confirms that the Treaty of Tien-Tsin which gave the British subjects the right to travel throughout the emperor's dominions did not apply to the peripheral area, such as Mongolia and Tibet. The conclusion of the Chefoo Convention showed that the British Government understood this to be the case, and indeed that none of the treaties between China and Britain concerning the Qing Empire as a whole were applicable to Tibet. ${ }^{60}$ For the British, the act of negotiating on the Chefoo Convention itself indicated that the British believed the imperial government possessed the authority to make treaties on Tibet's behalf. In addition, the term that 'the Chinese Resident in Tibet, with due regard to the circumstances, will send officers to take care of the Mission' is also indicative of the British opinion that the Resident was the actual

\footnotetext{
${ }^{57}$ H.E. Richardson, A Short History of Tibet, New York: E.P. Dutton \& Co, p 249.

${ }^{58}$ Kenneth Diplock, Passports and Protection in International Law, Transactions of the Grotius Society, Vol. 32, 1946, pp 42-59.

${ }^{59}$ Hu Zhongliang (胡忠良), Cong Dang'an Tan Wanqing Ouzhouren Zai Hua Youli (从档案谈晚清欧洲人在华游 历, the Study of Europeans' Traveling in China during the Late Qing Dynasty from the Perspective of Archives), Lishi Dang'an (历史档案, Historical Archives), vol. 2, 2002, pp 101-05.

${ }^{60}$ Amy Kellam, supra n.17, p 71.
} 
governor of Tibet at that time. For the Qing Government, the treaty upheld the idea that the imperial government maintained its grip upon Tibet. As Amy Kellam pointed out 'what the Chefoo Convention implied was that Tibetan acquiescence to Qing treaties made upon Tibet's behalf was mandatory rather than voluntary'. ${ }^{61}$ From this perspective, it is reasonable to argue that Britain tended to regard Tibet as a part of the Qing Empire.

\section{(2) Convention Relating to Burma and Tibet of 1886}

Although a consensus about sending a British mission to Tibet had been reached between China and Britain, the Tibetans protested when they heard of the provision of the Chefoo Convention from the Amban. ${ }^{62}$ They were convinced that their independent way of life and religion would be in danger, and they had no wish to replace Chinese control by a European Christian power. For this reason, Tibetans decided to resist any attempt to implement the Separate Article by declaring all Qing issued passports invalid and dispatching a military patrol to expel the British mission. ${ }^{63}$ Apart from the Tibetans, the Amban in Lhasa was probably the Qing official who most opposed the entry of foreigners into Tibet as he needed to avoid being hostile to the interests of the Tibetans. ${ }^{64}$ When the Tsungli Yamen learned that the British had privately contacted the Panchen Lama's Chief Minster, its official immediately informed O'Conor, the British Charge d'Affaires at Peking, that Tibet was not a dependency of China but 'an integral portion of the Chinese Empire', and thus the Panchen Lama had no power to deal with the British. Furthermore, the Tsungli Yamen also proposed to postpone the British mission on the ground that the Tibetans' opposition caused a 'special circumstance' referred to in the Separate Article. When British India occupied Upper Burma, an external tributary of the Qing, in 1884, the Qing Government offered to reach a settlement with Britain in which the Qing recognised British supremacy in Burma in exchange for the withdrawal of the Macaulay mission. ${ }^{65}$ The British unhesitatingly agreed to the offer proposed by the Chinese. Therefore, the Convention between Great Britain and China relating to Burma and Tibet was concluded in Peking in 1886. With respect to Tibet, Article IV of the Convention stipulated that:

\footnotetext{
${ }^{61}$ Ibid.

${ }^{62}$ R. S. Gundry, China and Her Neighbours, London: Chapman and Hall Lyd, 1893, p 128.

${ }^{63}$ Foreign Office (FO) 17 756, Fraster No. 142 of 16 July, 1877.

${ }^{64}$ For example, the tutor of the emperor, Sung Kuei, a former Amban at Lhasa, was very much opposed to any relaxation of the restrictions on foreigner's access to Tibet. See FO 17 984, O'Conor No. 423 of 10 Oct, 1885.

${ }^{65}$ Ibid, p 133. FO 17, 1063, O’Conor No. 178 of 31 May,1886.
} 
'Inasmuch as inquiry into the circumstances, by the Chinese Government, has shown the existence of many obstacles to the Mission to Tibet provided for in the separate article of the Chefoo Agreement, England consents to countermand the Mission forthwith. With regard to the desire of the British Government to consider arrangements for frontier trade between India and Tibet, it will be the duty of the Chinese Government, after careful inquiry into the circumstances, to adopt measures to exhort and encourage the people with a view to the promotion and development of trade. Should it be practicable, the Chinese Government shall then proceed carefully to consider trade regulations but if insuperable obstacles should be found to exist, the British Government will not press the matter unduly. 66

If the Separate Article of the Chefoo Convention had no intention to restrict the right of the British to deal with Tibet except through the Qing Government exclusively, then the Convention of 1886 removed all ambiguity on this question. It explicitly confirmed that arrangements for the frontier trade between India and Tibet were the duty of the Qing Government, which left the British with no excuse to contact Tibet in the absence of the Qing's participation. However, considering the continuous opposition of the Tibetans, it is reasonable to believe that the 'insuperable obstacles' would always exist, while the British government shall 'not press the matter unduly'. This is equal to admitting that the Qing Government had full control over Tibetan affairs, although the Qing's influence in Tibet was declining during that time. Together with the Chefoo Convention, these two Sino-British treaties in fact denied the possibility of Tibet being an independent State by implying it was part of the Qing Empire.

\section{(3) Convention Between Great Britain and China Relating to Sikkim and Tibet of 1890}

When O'Conor was arguing with the Yamen as to whether or not the Macaulay mission should be abandoned in 1886, the Kashag dispatched an expedition of 300 Tibetan soldiers to Lingtu and built a fortified gate on the road that crossed Lingtu. According to the ruler of Sikkim, Tibet once possessed this region, and the Tibetans had allowed Sikkim to regard this region as its own for many years. But according to the BritishSikkim Treaty of 1861 , the ruler of Sikkim had no right to cede or lease any of his

\footnotetext{
${ }^{66}$ IOR/L/PS/20/MEMO27/6 (India Office Record/Political and Secret Department Library: Memoranda: Burma and the North East Frontier), China-Burma negotiations 1885-1886. China. No 3 (1887). Convention between Her Majesty and His Majesty the Emperor of China relative to Burma and Tibet. Signed at Peking, July 24, 1886.
} 
territories to another State, and he was required to ban the armed forces of other States from passing through Sikkim territory unless the British allowed. ${ }^{67}$ The British apparently would not tolerate the military presence of the Tibetans in Lingtu but because of the restrictions imposed by the Convention of 1886 , they could not directly negotiate with the Tibetans. Therefore, John Walsham, the British minister in Peking, turned to the Yamen to solve the problem. The Yamen urged the Amban to persuade the Tibetans to withdraw from Sikkim, but the Tibetans refused to follow the Amban's instruction and hindered the Amban from visiting the disputed area. ${ }^{68}$ In March 1888, a British army with two thousand men expelled the Tibetans with little resistance. After the defeat of the Tibetans, the Amban Sheng Tai arrived in the Sikkim frontier to negotiate with Mortimer Durand, the Foreign Secretary of India. In order to prevent the British from contacting the Tibetans directly, the Amban had no other choice but to make an agreement with the British to solve the frontier dispute once and for all given that the Qing Empire was considerably weakened and the Imperial Court could hardly maintain a credible authority in Tibet. In this context, the Imperial Court hoped to use its recognition of Britain's direct and exclusive control over Sikkim in exchange for Britain's reconfirmation of the Qing's dominance over Tibet. In 1890, the Convention Between Great Britain and China Relating to Sikkim and Tibet was signed at Calcutta. In respect to Tibet, the Convention of 1890 stipulated that:

'I. The boundary of Sikkim and Tibet shall be the crest of the mountain range separating the waters flowing into the Sikkim Teesta and its affluents from the waters flowing into the Tibetan Mochu and northwards into other rivers of Tibet. The line commences at Mount Gipmochi on the Bhutan frontier, and follows the above-mentioned waterparting to the point where it meets Nepal territory.

III. The Government of Great Britain and Ireland and the Government of China engage reciprocally to respect the boundary as defined in Article I, and to prevent acts of Aggression from their respective sides of the frontier.

IV. The question of providing increased facilities for trade across the Sikkim-Tibet frontier will hereafter be discussed with a view to a mutually satisfactory arrangement by the High Contracting Powers.

\footnotetext{
${ }^{67}$ Appendix 1 Treaty of 1861 between Ashley Eden and the Maharaja of Sikkim in Queeny Pradhan, Empire in the Hills: Simla, Darjeeling, Ootacamund, and Mount Abu, 1820-1920, Oxford University Press, 2017, p 352.

${ }^{68}$ FO 17 1108, India Foreign Letter No. 128 of 21 July, 1888. See the map of Sikkim-Tibet in Map IV in Appendixes.
} 
VI. The High Contracting Powers reserve for discussion and arrangement the method in which official communications between the British authorities in India and the authorities in Tibet shall be conducted., ${ }^{, 69}$

Article I of the Convention clarified the fixed Tibetan-Sikkim border. In international law, boundaries are a key element of the exercise of State power and sovereignty as they determine the extent of the State's territory and jurisdiction. Therefore, States should be extremely prudent when conducting negotiations and concluding agreements on this issue. ${ }^{70}$ According to an opinion of International Court of Justice (ICJ), 'the fixing of a frontier depends on the will of the sovereign States directly concerned., ${ }^{71}$ The ICJ's view, as an observation of State practice for the past few centuries, indicated that the right of demarcation should only be attributed to sovereign States. In the meantime, these sovereign states should have a direct concern over the disputed area. With regard to the Convention of 1890, Article I was apparently a demarcation arrangement which defined Tibetan-Sikkim frontier between China and Britain. From this perspective, the two high contracting parties had already reached a consensus that Sikkim was under the sovereignty of Britain and Tibet was under the sovereignty of the Qing. Apart from Article I, Article III emphasised the Qing's obligation to prevent acts of aggression from the Tibetan side. It indicated indirectly that the British believed the Imperial Court enjoyed jurisdiction over the Tibetans. It is worth noting that there are some ambiguities in Article VI, which referred to the official communications between the British authorities in India and the authorities in Tibet. What did the authorities in Tibet mean? Did it refer to the Chinese Amban or the Kashag government? The answer can be found in the 1886 Convention Relating to Burma and Tibet. It implicitly confirmed China's exclusive right to deal with the British on Tibetan affairs. Therefore, it was the Amban's responsibility to arrange the method for official communications between India and Tibet. Although the British realised that the Amban already had no power in Tibet, ${ }^{72}$ the Sikkim-Tibet Convention again confirmed the Chinese authority

\footnotetext{
${ }^{69}$ APPENDIX 6 Convention between Great Britain and China Relating to Sikkim and Tibet Signed at Calcutta, 17 March 1890 in A.G. Noorani, India-China Boundary Problem 1846-1947, Oxford University Press, p 264.

${ }^{70}$ Alberto Alvarez Jimenez, Boundary Agreements in the International Court of Justice's Case Law, 2000-2010, the European Journal of International Law Vol. 23 no. 2, 2012, pp 495-515.

${ }^{71}$ Case Concerning the Territorial Dispute (Libyan Arab Jamahiriya/Chad), ICJ Judgment of 3 Feb. 1994, ICJ Rep 6, at para. 45 .

${ }^{72}$ Li Hongzhang once said:" The Yamen may promise what they like - but it is quite impossible in the present state of relations between China and Tibet for them to carry out their promise. People talk of China's influence in Tibet but it is only nominal, as the Lamas are all powerful there." Durand had felt that: "the Amban was frightened of the
} 
over Tibet, and it successfully prevented the British from dealing directly with the Tibetans.

During the eighteenth century, the British began to be involved in Tibet to secure the northern frontier of India and to facilitate trade with China. By sending George Bogle to Shigatse, the British initiated its first contact with the Tibetans and gained the friendship of the Panchen Lama. But their ambiguous role in the Qing-Gurkha war had greatly hindered progress in developing relations with the Qing Government and the Tibetans. As the British were aware of the presence and influence of the Qing in Tibet, they tried to avoid direct involvement in Tibetan affairs. In the meantime, they did not take a definite position on Sino-Tibetan relations in their early participation. With the expansion of the influence in the Himalayas, the British signed a series of Tibet-related treaties with the Qing Government. Instead of recognising Tibet as an independent State, these treaties implied that the British were inclined to treat Tibet as a part of the Qing Empire and that they believed the Qing Government maintained its authority in Tibet. By concluding these treaties, the British restrained themselves from directly dealing with the Tibetans other than through the Qing government.

\section{Conclusion}

It was not until the Opium War in 1840 that China began to learn about international law and utilised it as a tool to deal with Western powers. However, as a non-Christian empire, the eligibility of China to conclude treaties with Western powers was sometimes questioned by some international jurists because of doubt over whether China met the criteria of a 'civilised State'. In the meantime, some natural law theorists acknowledged the non-Western people's sovereignty and their capacity to participate in international law. As for the case of China, the Institut de Droit International clearly affirmed that China should be regarded as the subject of international law. In addition, on the issue of the validity of unequal treaties concluded between China and Western powers under force or coercion, legal theory and State practice of the nineteenth century were inclined to support the premise that the use of force or coercion did not

Tibetans. He was only a guest in Lhasa - not a master - and he could not put aside the real masters.” See P. Sykes, Sir Mortimer Durnad, London: Cassell and Company, 1926, p 163-6. 
automatically invalidate a treaty. Accordingly, the treaties between China and Britain relating to Tibet should be regarded as valid treaties according to international law.

Although little can be learned from the early British involvement as to what position the British held on the status of Tibet, the early Tibet-related treaties concluded between China and Britain to some extent implied the British attitude towards this issue. The request in the Separate Article of the Chefoo Convention that the Zongli Yamen issued passports for a British mission to Tibet suggests that the British tended to regard Tibet as a part of the Qing Empire. The Convention Relating to Burma and Tibet in 1886 explicitly confirmed the Qing's responsibility to arrange the frontier trade between India and Tibet, and it gave the British no reason to deal with the Tibetans without the involvement of the Qing government. In the Sikkim-Tibet Convention, the Qing's full authority over Tibet was indirectly demonstrated by China and Britain's delineation of the Tibet-Sikkim frontier. However, both high contracting parties realised that the Chinese influence in Tibet was only nominal, as the Lamas' influence was rising rapidly. 


\section{Chapter 4 The Status of Tibet Under the 'Great Game'}

\section{Introduction}

After discussing the early British involvement in Tibet before the twentieth century, this chapter aims to explore the status of Tibet by analysing the radical change in British policy towards Tibet during the first decade of the twentieth century. At this stage, the confrontation between Britain and Russia over Central and South Asia, known as the 'Great Game', had become increasingly fierce. Tibet was inevitably brought into the chessboard of imperialist expansion for its strategic importance. In the meantime, the conclusion of the Sino-British Convention of 1890 had not only demarcated the SikkimTibet boundary but also gave Britain the privilege to establish a trade mart at Yatung in Tibet. However, due to the strong opposition from the Tibetans, the British made little progress in carrying out the above two matters. It was in this context that British India in 1903 decided to conduct a military expedition to Tibet to force the Tibetans to fulfil the treaty. As a consequence of the expedition, the British bypassed the Qing Government and signed the Lhasa Convention with the Tibetans in 1904. Compared with the previous Sino-British Tibet-related treaties, this convention made the status of Tibet ambiguous as it was the first treaty signed by the British and the Tibetans. In order to reinforce the privilege gained from the Lhasa Convention, the British signed in 1906 a new convention with the Qing Government which attached the Lhasa Convention of 1904 as an annex to it. At this time in Europe, Great Britain and Russia decided to calm their confrontations in Central and South Asia to prevent the rapid rise of Germany and an Anglo-Russian Convention was signed in 1907 in which both Powers recognised China's 'suzerain' right over Tibet. Although it cannot be concluded from the above treaties that Tibet was regarded as an independent State by Britain or Russia, these treaties to some extent undermined the Qing's sovereign claim over Tibet as they significantly blurred its status.

This chapter explores the origin of the dispute over Tibet's legal status during the period of the Republic of China (1912-1949) by exploring the policies of China, Britain and Russia on Tibet in the first decade of the twentieth century. For this purpose, the 
Convention Between Great Britain and Tibet of 1904, the Convention Between Great Britain and China Respecting Tibet of 1906 and the Convention Between Great Britain and Russia of 1907 are studied as primary sources to reveal the positions of these Powers on Tibet's status. In addition, the Tibet-related correspondence and telegraphs from the British India Office and the Foreign Office serve as secondary sources to discuss the causes and consequences of the British expedition to Tibet as well as the Anglo-Russian negotiations over Tibet. In order to find out what is suzerainty and whether the Qing's authority over Tibet was a suzerain right, articles and books on suzerainty are also examined as secondary sources.

This chapter contains three sections. The first section discusses the British military expedition of 1903 and the conclusion of the Lhasa Convention of 1904. The second section gives attention to the Sino-British Convention Respecting Tibet of 1906. It not only involves a detailed observation on Sino-Tibetan relations confirmed by the Convention of 1906 but also explores the relationship between this convention and the Lhasa Convention of 1904. The divergence between China and Britain on the status of Tibet is shown by examining the legal nature of the Lhasa Convention and its relationship with the Sino-British Convention of 1906. The third section focuses on the interpretation of the Anglo-Russian Convention of 1907. It first discusses the impact of this convention on Britain's and Russia's positions on Sino-Tibet relations. The discussion then moves to the concept of 'suzerainty', which was used to define SinoTibetan relations in the convention of 1907. It refers to the definition of suzerainty and its differences with sovereignty in international law. After that, the last part of the section preliminarily answers the question of whether Tibet was under the suzerainty or sovereignty of the Qing Government in the first decade of the twentieth century. A further exploration on this question will be made in the next chapter by analysing the Qing Government's reforms in Tibet in the first decade of the twentieth century.

\subsection{The British Invasion of Tibet and the Lhasa Convention}

During the second half of the nineteenth century, the British had made significant progress in Tibet through dealing with the Qing Government. By concluding the SinoBritish Convention of 1890, the Qing Government and the British Government settled the boundary dispute between Tibet and Sikkim. Under the 1893 Trade Regulation 
appended to the 1890 Convention, the British also gained the right to establish a trade mart on the Tibetan side of the frontier. ${ }^{1}$ However, as the Qing's authority in Tibet had declined since the mid-nineteenth century, the Amban in Lhasa could hardly persuade the Tibetans to abide by the Sino-British treaties on Tibet, and little progress was made in actual demarcation work for more than ten years because the Tibetans claimed that they had not participated in the negotiations. In fact, once the Chinese and British Commissioners fixed the boundary pillars, the Tibetans would promptly destroy them to suspend the work. ${ }^{2}$ As for the establishment of the trade mart at Yatung, the Tibetans neither allowed the British subjects to enter Tibet nor were they willing to dispatch representatives for further negotiations. ${ }^{3}$ The British gradually realised that they could not rely on the Qing Government to fulfil its obligations, considering that its authority over Tibet had become merely a constitutional fiction. ${ }^{4}$ Therefore, forcing the Tibetans to perform the provisions of the treaty became the fundamental motive behind the 1903 military expeditions to Tibet. But what worried the British more was Russia's increasing involvement in Tibet. As Russia was emerging as a potential threat to the security of India's northeast border, the British felt that an urgent response had to be made to prevent the expansion of the Russians in Tibet. It was against this background that the British decided to launch its 1903 expedition to Tibet. In order to understand the causes and consequences of this expedition, this section first examines the Russian factor behind the British invasion of Tibet. It discusses Russia's expansion of influence in Tibet by receiving Tibetan missions at the end of the 1890s. Russia's position on the status of Tibet is then presented through an examination of Russian officials' statements on the nature of these Tibetan missions. After briefly introducing the process of the expedition, the second section focuses on the outcome of the expedition, the Lhasa Convention of 1904, including the process of concluding the treaty, its contents and its influence on Tibet's status.

\subsubsection{Russian Factor in the British Expedition to Tibet}

\footnotetext{
${ }^{1}$ See the Article I of the Sino-Anglo Convention in 1890 and the Article I and II of the Regulations Regarding Trade, Communications and Pasturage of 1893 (Appended to the Convention of 1890).

${ }^{2}$ IOR/L/PARL/2/334, Enclosure in No. 56, Letter from Sir E. Satow to Prince Ch'ing, dated September 9, 1902.

${ }^{3}$ Alex Mckay, The British Invasion of Tibet, 1903-04, Inner Asia, Vol. 14, No. 1, pp 5-25.

${ }^{4}$ The Times in Beijing, 27 January, 1904, cited in Henry Sanderson, Transgression of the Frontier: An Analysis of Documents Relating to the British Invasion of Tibet, Inner Asia, 2012, Vol. 14, No. 1, p 43-4.
} 
According to Samuel Turner, Russia's interests in Tibet could be traced back to the late eighteenth century, but for nearly a century the Russians did not appear to make any direct efforts to extend their influence in Tibet. ${ }^{5}$ When it came to the late nineteenth century, Russia had begun to indirectly expand its influence in Tibet out of the need to compete with British India. ${ }^{6}$ Many Buriat-Mongol lamas, who were subjects of Russia, had visited Lhasa and attempted to persuade the Tibetan lamas to get close to Russia. ${ }^{7}$ Among them, a Buriat-Mongol named Agvan Dorjief, who studied Buddhism at Drepung Monastery for more than twenty years, had successfully gained the trust of the $13^{\text {th }}$ Dalai Lama and persuaded him to cultivate a friendship with Tsar Nicholas II as a countermeasure to the British provocation. ${ }^{8}$ In 1898 , Dorjief was dispatched by the $13^{\text {th }}$ Dalai Lama to Russia and met the Tsar in the Livadia Palace at Odessa. ${ }^{9}$ Until then, the activities of Dorjief's mission were not noticed by the British. But things quickly changed when the Russian Press extensively reported Dorjief's second mission in the following year. This time, Dorjief not only met with the Tsar but also with the Minister of Foreign Affairs and Minister of Finance in St. Petersburg. ${ }^{10}$ These reports which attributed an official and diplomatic character to Dorjief's visits, not surprisingly aroused the suspicion of the British India Government on the objectives of the mission.

The British ambassador, Charles Scott, asked Lamsdorf, the Russian Foreign Minister, to clarify the nature of the mission. Lamsdorf utterly denied any diplomatic or political character of these Tibetan visitors and emphasised that Dorjief was a Mongolian Buriat of Russian origin. ${ }^{11}$ With regard to Tibet's status, he further claimed that 'it was difficult to understand how Russian press, in view of the international position of Tibet as a

\footnotetext{
${ }^{5}$ See Francis E. Younghusband, Memorandum on Our Relations with Tibet - Both Past and Present, Simla: Printed at the Government Central Printing Office, 1903, p 21. In his work, Turner argued that the doings of Russia were known to the Tibetans "even in $1783 \ldots . .$. Many overtures had been made on the part of Russia to extend her commerce to the internal parts of Tibet, but their disinclination to enter into any new foreign connection, and the watchful jealousy of the Chinese, had hitherto defeated every attempt of this nature".

${ }^{6}$ In February 1902 the Russian War Minister recorded in his diary that the Tsar Nicholas II had plans to establish Russian protectorate over Tibet. See V. Shatsillo, L. Shatsillo Russko-I' aponskai'a voina 1904-1905 (Moscow, 2004), p 191. Cited from Marina Soroka, Britain, Russia and the Road to the First World War: The Fateful Embassy of Count Aleksandr Benckendorff, Routledge, 2016, p 63.

${ }^{7}$ Younghusband, p 22.

${ }^{8}$ Parshotam Mehra, The Great Game: Russia's Role in the Persian Empire and Tibet, Asian Affairs, 2004, Volume 35, Issue 2, p 202.

${ }_{9}^{9}$ Alexandre Andreyev, Indian Pundits and the Russian Exploration of Tibet: An Unknown Story of the Great Game Era, Central Asiatic Journal, 2001, Vol. 45, No. 2, p 177.

${ }^{10}$ According to the Russian newspaper Novoe Vremya, after knowing Russian victories in Manchuria, it was natural for the Dalai Lama to realize Russia was the only power able to counteract the intrigues of the Great Britain, and meanwhile Russia had long been endeavoring to obtain admission, and only awaits an opportunity to force an entrance. From Novoe Vremya of June 17 (30), 1901, IOR/L/PARL/2/334, Enclosure in No. 34, Summaries of Articles in the Russian Press.

${ }^{11}$ IOR/L/PARL/2/334, No. 35, Dispatch from Sir C. Scott to the Marquess of Lansdowne, dated St. Petersburg, July 4, 1901
} 
dependency of China, could have attributed an official or diplomatic character to the Lama's visit to Russia'. ${ }^{12}$ Although Lamsdorf did not provide any further explanation of the meaning of 'dependency' in Sino-Tibetan relations, Dr Badmeyeff, who served as an advisor on the Russian Foreign Ministry, gave his understanding of this issue in an interview with Novoe Vremya:

'The administration of Tibet is entrusted to two Chinese Ambans, who, according to the Chinese law, are on an equal footing with the Dalai Lama and Panchen Lama, and particularly have great power. The Dalai and Panchen may do nothing in opposition to the Ambans. For instance, the Chinese law enacts that the Dalai and the Panchen may only enter into communication with the foreign Courts and nations through the Ambans......Indeed, they can do nothing without the approval of the Ambans......Russia is doing everything to uphold the integrity of China, and therefore, Tibetans, subjects of the emperor of China, come to pray for assistance against any attack on Tibet, will certainly be received with welcome.' 13

According to Lamsdorf, the Russian Government apparently did not regard Tibet as an independent State. Instead, he described that the relation between Tibet and China was a 'dependency' relationship, albeit he did not offer a precise definition of dependency. Badmeyeff's opinion, as a supplement to Lamsdorf's position, clearly indicated that Tibet was under the authority of the Qing Government according to Chinese law. The law to which he referred must have been the Twenty-Nine Regulations for Better Government in Tibet of 1792 which significantly expanded the ambans' power in the Tibetan administration. ${ }^{14}$ His statement on respecting the integrity of China also showed that Russia regarded Tibet as a part of China at the end of the nineteenth century. However, he could not fail to notice that Chinese influence in Tibet had weakened, while the young $13^{\text {th }}$ Dalai Lama had shown his readiness to take charge of all Tibetan affairs. Therefore, Badmeyeff carefully created some ambiguities on Russia's attitude towards Dorjief's mission. On the one hand, in order to relieve British suspicions of Russia's intentions in Tibet, he acknowledged that Tibetans were subjects of the emperor of China; on the other hand, although he knew that the mission was not authorised by the Qing Government, he still welcomed the Tibetans to seek help from Russia. Badmeyeff's statement not only contradicted Lamsdorf's assertion that the

\footnotetext{
${ }^{12}$ Ibid.

${ }^{13}$ Ibid, From the "Novoe Vremya" of June 20, 1901. Enclosure in No. 35, Extract from the Russian Press.

${ }^{14}$ With regard to the Regulations, see Section 2.3.3 in the Chapter 2.
} 
mission was not diplomatic in nature but was also inconsistent with his claim that Tibetans were subjects of the Chinese emperor. It can be seen from these statements that Russia at the time adopted a flexible rather than a clear policy on Tibetan affairs. Recognition of China's authority over Tibet would relieve British hostility toward Russia's ambition to turn Tibet into its protectorate. In turn, it would also create an obstacle to British plans to possibly annex Tibet. But if suitable opportunities were to arise, direct contact between the Tibetans and the Russian court would be welcomed.

Although the statements of Lamsdorf and Badmeyeff to some extent calmed British anxieties, the British still explicitly expressed that His Majesty's Government could not regard with indifference any proceedings that might tend to alter or disturb the current status of Tibet. ${ }^{15}$ Soon after the incident of the Tibet mission had calmed down, British suspicions over Russia's intentions in Tibet were once again provoked by a rumour that the Russian Government had attempted to conclude a secret treaty with the Qing Government concerning Tibet. According to the information that had been gained by Edward Satow, the British ambassador to China, China would transfer its control over Tibet to Russia in exchange for the latter's promise to uphold the integrity of China. ${ }^{16}$ Out of fear that Russia would turn Tibet into its protectorate and then invade India from Tibet, Lansdowne, the British Foreign Minister, instructed Satow to convey a warning from the British Government to the Qing Government against the conclusion of any arrangement of this kind. If such an agreement existed, the British Government would certainly be forced to take steps to protect its interests. ${ }^{17}$ In response to Satow's inquiry, Prince Ch'ing, the Minister of Chinese Foreign Affairs, denied the existence of such an agreement with Russia. Similarly, Benckendorff, the Russian ambassador in London, assured Lansdowne that the rumour of the secret agreement was without foundation. He went on to say that although Russia had no designs on Tibet, it could not remain indifferent to any serious disturbance of the status quo in Tibet, and such disturbance might force it to safeguard its interests in Asia because it regarded the integrity of the

\footnotetext{
${ }^{15}$ IOR/L/PARL/2/334, No. 39, Dispatch from the Marquess of Lansdowne to Sir C. Scott, dated Foreign Office, August 16, 1901.

${ }^{16}$ According to China Times of July 18, 1902, this secret Agreement between China and Russia stipulated that the Chinese Government agreed to relinquish her entire interest in Tibet to Russia excepting her right to appoint consuls and to continue her normal trading, and Russia was to control all Tibetan affairs, construct railway lines and develop mining. In exchange Russia undertook to suppress all disturbance occurring in the interior of China which the Chinese Government unable to cope with and to assist in maintaining the integrity of the Chinese Empire. See IOR/L/PARL/2/334, No. 49, Dispatch from Sir E. Satow to Marquess of Lansdowne, dated Peking, August 5, 1902.

${ }^{17}$ IOR/L/PARL/2/334, No. 52, Telegraph from the Marquess of Lansdowne to Sir. Satow, dated September 1, 1902.
} 
Chinese Empire as a Russian interest. ${ }^{18}$ He hoped that there was no question of any action on the British part with regard to Tibet which might cause the disintegration of China. ${ }^{19}$ Facing Russia's counter-protest for the British designs on Tibet, Lansdowne insisted that Great Britain had treaties with the Tibetans and a right to trade facilities, and the British would insist on their rights if the Tibetans did not fulfil their treaty obligations. ${ }^{20}$ In fact, the British Government had concluded only three Tibet-related treaties with the Qing Government, and neither of them made Tibet a contracting party of the convention. ${ }^{21}$ Thus, the Qing, rather than Tibet, were obliged to carry out the provisions of the treaties. But considering that the Qing's authority in Tibet was declining, Lansdowne's reply somehow showed that the British had lost patience with the Qing Government and was prepared to deal with the Tibetans directly.

It can be seen from the above events that Russia at the end of the nineteenth century recognised Tibet as a part of China, but at the same time, took a favourable position on intervening in Tibetan affairs. This inevitably caused the British to doubt Russia's intentions in Tibet against the backdrop of the 'Great Game'. Although the Russian Government repeatedly emphasised the unofficial nature of the Tibetan mission and the non-existence of a secret agreement, the British India Government was convinced that Russia's presence in Tibet would pose a severe threat to the security of India. In this sense, the Russian factor constituted one of the crucial reasons for the British military expedition to Tibet in 1903.

\subsubsection{The British Expedition to Tibet}

Considering that the Qing Government was unlikely to persuade the Tibetans to accept the Sino-British Convention of 1890, the British believed no satisfactory result would be gained if the Tibetans still refused to participate in the implementation of the conventions. Therefore, Lord Curzon, the governor-general of India, tried to improve communication with the $13^{\text {th }}$ Dalai Lama and to persuade him to send representatives

\footnotetext{
${ }^{18}$ According to the Marquess of Lansdowne, Benckendorff regarded Tibet as forming a part of the Chinese empire, and the Lansdowne replied him that the Great Britain had no idea of annexing Tibet. See IOR/L/PARL/2/334, No. 83, Dispatch from the Marquess of Lansdowne to Sir C. Scott, dated April 8, 1903.

${ }^{19}$ Ibid.

${ }^{20}$ Ibid.

${ }^{21}$ See the Separate Article in Chefoo Convention of 1876; the Convention Relating Burma and Tibet of 1886 and the Convention Between Great Britain and China Relating to Sikkim and Tibet of 1890.
} 
to the delimitation negotiations. He twice wrote to the $13^{\text {th }}$ Dalai Lama expressing the wish to establish friendly relations between India and Tibet and urging him to carry out the treaties as soon as possible. But the latter returned the unopened letter with no further response. ${ }^{22}$ Under the pressure of the amban, the $13^{\text {th }}$ Dalai Lama eventually agreed to dispatch two Tibetan officials to the Sikkim-Tibet frontier negotiations. However, the rank of these officials was questioned by Lord Curzon as they were not properly accredited to make any agreement with the British. ${ }^{23}$ What was more unacceptable to the British was that the Tibetan delegates refused to hold any communication with British Commissioner White on the grounds that the latter had brought troops to the place of negotiation on the Tibetan side of the frontier. ${ }^{24}$ Curzon then realised that Britain's past Tibetan policy was a complete failure and that a policy shift was needed to reverse the current situation. ${ }^{25}$ For him, the only practical way was to send a British mission to Lhasa and to negotiate an Anglo-Tibetan treaty. The War Office in London also considered that a mission to Lhasa was an acceptable solution to the threat of Russia in Tibet. ${ }^{26}$ But Curzon's plan did not initially obtain support from Lord George Hamilton, the Secretary of State for India. In a reply to Curzon, he stated that:

‘......Your Excellency's proposal to send an armed mission to enter Lhasa, by force if necessary, and establish there a Resident, might, no doubt, if the issue were simply one between India and Tibet, be justified as a legitimate reply to the actions of the Tibetan Government in returning letters you have addressed to them, and in disregarding the Convention with China of $1890 \ldots$.... Such action undoubtedly warrants the adoption of strong measures, and I have expressed this opinion in my dispatch of the $16^{\text {th }}$ August 1901. But His Majesty Government cannot regard the question as one concerning India and Tibet alone. The position of China, in its relations with the Powers of Europe, has been so modified in recent years that it is necessary to take into account those altered conditions in deciding on action affecting what must be still regarded (Tibet) as a province of China. It is true that we have no desire either to declare a protectorate or permanently to occupy any portion of the country. Measures of this kind might become

\footnotetext{
${ }^{22}$ Ibid., Enclosure 3 and Enclosure 4 in No. 37, Letter from the Viceroy and Governor-General of India to the Illustrious Dalai Lama, dated Simla, the 11th August, 1900 and the 8th of June, 1901.

${ }^{23} \mathrm{IOR} / \mathrm{L} / \mathrm{PARL} / 2 / 334$, No. 129, Letter from the Government of India in the Foreign Department to His Majesty's Secretary of State for India, dated Simla, the $5^{\text {th }}$ of November, 1903.

${ }^{24}$ Ibid, No. 123, Telegraph from the Viceroy to the Secretary of State for India, dated $26^{\text {th }}$ October, 1903.

${ }^{25}$ Alastair Lamb, British India and Tibet 1766-1910, Routledge \& Kegan Paul Press, 1986, p 224.

${ }^{26}$ FO 17/1745, The Director-General of Mobilization and Military Intelligence presents his compliments to the Under Secretary of State for Foreign Affairs, 2th of October, 1902.
} 
inevitable if we were once to find ourselves committed to armed intervention in Tibet, and it is almost certain that, were the British Mission to encounter opposition, questions would be raised which would have to be considered, not as local ones concerning Tibet and India exclusively, but from an international point of view, as involving the status of a portion of the Chinese Empire. ${ }^{27}$

Hamilton's reply indicated that the British Government still regarded Tibet as a portion of China; more precisely, a province of China. In fact, the disagreement between Hamilton and Curzon to some extent reflected that the interests of London and India did not necessarily coincide. The British Government hoped to avoid provoking China as much as possible in order to maintain its substantial economic interests in China. For British India, security was the top priority, namely preventing Russia from invading India. ${ }^{28}$ Even if the British government still preferred to negotiate with the Chinese and Tibetans on the Sikkim-Tibet frontier, it finally lost all patience when the news that the Tibetans had been preparing for war for months reached London. It is in this context that the British Government decided to authorise Colonel Younghusband to go on an expedition to Tibet. $^{29}$

In July 1903, the Tibetans arrested two men from Sikkim who were considered to be British spies on their way to Shigatse. This undoubtedly strengthened the determination of the British to take action. ${ }^{30}$ Soon afterwards, the India Office permitted the dispatch of a mission led by Younghusband to march into Tibet. The mission, consisting of over 8,000 men, left Khambajong in December 1903 and advanced through the Chumbi Valley to Phari Dzong, the Tibetan frontier post. In March 1904, the mission continued its advance to Guru, where it had the first armed clash with the Tibetans. The engagement caused over 500 Tibetan casualties, whereas there were only a few wounded in the British army. After the battle in Guru, the mission arrived in Gyantse

\footnotetext{
${ }^{27}$ IOR/L/PARL/2/334, No. 78, Dispatch from the Right Honorable Lord George Hamilton, His Majesty’s Secretary of State for India to His Excellency the Right Honorable the Governor-General of India in Council, dated February 27, 1903.

${ }^{28}$ Alex Mckay, supra n.3, pp 5-25.

${ }^{29}$ According to the report from Lord Curzon, "Tibetans have for months past been preparing for war, collecting troops and supplies in every part of the country between Lhasa and our frontier." See IOR/L/PARL/2/334, No. 123, From the Viceroy to the Secretary of State for India, dated 26th of October, 1903. See the map of British Expedition to Tibet in Map V in Appendixes.

${ }^{30}$ According to the report of Younghusband, the Tibetans not only refused to release these two British subjects, but also sent no reply to any of British representations after the rumors of ill-treatment of these prisoners spread among the India Government, which Curzon described as "the most conspicuous proof of the hostility of the Tibetan Government" See IOR/L/PARL/2/334, No. 123; Papers Relating to Tibet 1904, pp 219-21: Curzon to Brodrick, 5th of November, 1903, cited from Alastair Lamb, British India and Tibet 1766-1910, p 235.
} 
on 11 April of 1904, where Younghusband remained for three months. On 14 July, Younghusband decided to make his final advance to Lhasa.

The Qing Government, having been informed by the Chinese Minister in London that British troops had been sent into Tibet, requested the British Foreign Minister to withdraw the mission from China's 'obstinate and arrogant vassal' ${ }^{31}$ In response, the British Foreign Minister pointed out that the Chinese authority had failed to reduce the Tibetans' increasing hostilities towards the British and to fulfil its treaty obligations; therefore, it was impossible for the British Government to withdraw the mission. ${ }^{32}$ For the Qing Government, Younghusband's mission had sabotaged its authority over Tibet, but it was already too weak to make the British withdraw the expedition. In a letter from the Chinese Foreign Ministry, Yu-Gang (裕钢), the amban in Lhasa, was asked to meet and negotiate with the British officials. ${ }^{33}$ But Yu-Gang knew that even if he could persuade the British to withdraw the mission, he could not persuade Tibetans to participate in the negotiation of the Sikkim-Tibet demarcation.

As the British army approached Lhasa, the 13th Dalai Lama decided to flee to Urga in Mongolia. His escape happened to provide You Tai (有泰), the newly appointed amban, with an opportunity to increase Chinese authority over Tibet. The Qing Government issued an imperial decree denouncing and deposing the $13^{\text {th }}$ Dalai Lama for his escape without permission. ${ }^{34}$ At the same time, You Tai came up with the idea of utilising the British military to reassert his lost authority in Tibet. He called on Younghusband and expressed his readiness to work with the latter in effecting a speedy settlement with the Tibetans. ${ }^{35}$ The Qing Government also approved You Tai's action. In a telegraph to You Tai from $W a i-W u-B u$ (外务部), the Minister of Foreign Affairs, the amban was instructed to persuade the Tibetans and lead them to negotiate with the British. ${ }^{36}$ As for Younghusband, he also felt that the Tibetans 'would not have come off so easily in the

\footnotetext{
${ }^{31}$ IOR/L/PARL/2/334, No. 146, Note from Chang Ta-jen to Marquess of Lansdowne, dated Chinese Legation, London, the 23rd November, 1903.

${ }^{32}$ IOR/L/PARL/2/334, No. 148, Note from Marquess of Lansdowne to Chang Ta-jen, dated the 28th November, 1903.

${ }^{33}$ Duojie Cai'dan (多杰才旦), Study on the relations between the Tibetan Local Government and the Central Government Since the Yuan Dynasty (元以来西藏地方政府与中央政府关系研究), Vol.2, Chinese Tibetology Press (中国藏学出版社), pp. 738-69.

${ }^{34}$ Michael C. Van Walt Van Praag, The Status Of Tibet: History, Rights, And Prospects In International Law, Westview Press, 1987, p 34.

${ }^{35}$ Francis E. Younghusband, India and Tibet, London: John Murray, Albemarle Street, 1910, p 264.

${ }^{36}$ The Memorials of You Tai in Tibet, see Wu Fengpei (吴丰培), in The Memorials of Tibetan Affairs in the Qing Dynasty(清代藏事奏牍), the Chinese China Tibetology Press, 1994, p 1190.
} 
ensuring settlement if the Chinese had not interceded on their behalf' ${ }^{37}$ He then asked You Tai to make the Tibetans depute two or three representatives to negotiate a settlement with him. ${ }^{38} \mathrm{~A}$ talk that was more coercive than negotiable then began between Younghusband, You-Tai and the Tibetan representatives. ${ }^{39}$ The next section addresses the process of concluding the Lhasa Convention, its content and its influence on shaping the status of Tibet in the early twentieth century.

\subsubsection{The Conclusion of the Lhasa Convention}

As Lamb rightly pointed out, 'the gains of the mission to Lhasa, whatever they might be, would have to be embodied in some sort of treaty between Younghusband and the Tibetans, preferably with Chinese adhesion'. ${ }^{40}$ On 1 September 1904, Younghusband presented a draft of the treaty in English, Chinese and Tibetan to You Tai, who then handed the Tibetan copy to Ti Rimpoche, the regent of Tibet, and members of the Tibetan National Assembly. Younghusband told the Tibetans that he was prepared to explain any point in the draft which they did not understand, but he could not further discuss the terms and only gave them one week to reply. ${ }^{41}$ Almost a week later, the draft was signed and sealed by Younghusband on behalf of the British Government and by the regent, the Tibetan Local Government (Kashag) and the Three Monasteries for Tibet in the presence of You Tai in the Potala Palace.

The Lhasa Convention contained nine articles. The treaty not only demanded that the Tibetans respect the Anglo-Chinese Convention of 1890 and recognise the frontier between Sikkim and Tibet but also stipulated that Tibet shall open trade marts at Gyangtse, Yatung and Gartok; pay a large indemnity of 75 lakhs of rupees to the British Government, while the British Government would continue to occupy the Chumbi Valley until the indemnity had been paid; and, most importantly, prevented Tibet from having relations with any other foreign powers without British consent. ${ }^{42}$

\footnotetext{
${ }^{37}$ Younghusband, p 266.

${ }^{38}$ Ibid.

${ }^{39}$ Li Tieh-Tseng, The Historical Status of Tibet, New York: King’s Crown Press, 1956, p 93.

${ }^{40}$ Lamb, supra $\mathrm{n} .25, \mathrm{p} 243$.

${ }^{41}$ Li Tieh-Tseng, pp 95-6.

${ }^{42}$ See Articles I, II, VI, VII, and IX of the Lhasa Convention. With regard to the Article IX, "the Government of Tibet engages that, without the previous consent of the British Government, a. No portion of Tibetan territory shall be ceded, sold, leased, mortgaged or otherwise given for occupation, to any foreign Power; $b$. No such Power shall be permitted to intervene in Tibetan affairs; c. No Representatives or Agents of any foreign Power shall be admitted
} 
Concerning the Qing's attitude towards the Lhasa Convention, You Tai had sent the draft of the treaty to $W a i-W u-B u$, asking whether or not he should attach his signature on the draft as Younghusband had tried to persuade him to do during the negotiation. ${ }^{43}$ In response, $W a i-W u-B u$, for the first time, made it clear that the draft would undermine the Qing's sovereignty over Tibet and instructed You Tai not to sign it. Wai-Wu-Bu further pointed out that both the Convention of 1890 and the Regulations of 1893 concerning Tibet were exclusively concluded by the Qing Government and the British Government, and this time should be no exception. Given the previous precedent and for the purpose of demonstrating the Qing's inherent sovereignty over Tibet, the amban should lead the Tibetans to negotiate with the British and sign the treaty jointly with the Tibetans. ${ }^{44}$ After learning that Younghusband had already forced the Tibetans to sign the draft, Wai-Wu-Bu further instructed the amban not to attach his signature to the draft, considering that Article IX, which stipulated that Tibet's external affairs should be guided by the British, greatly damaged China's sovereignty over Tibet. If the Qing Government signed this agreement, the other Western powers would claim similar rights in Tibet seeing that almost all commercial treaties concluded between China and Western powers contained one-sided most-favoured-nation clauses. ${ }^{45}$ Therefore, a further negotiation was needed to clarify the Qing's authority in Tibet.

With respect to the attitude of London towards the Lhasa Convention, Mr Brodrick, the Secretary of State for India at that time, pointed out to Lord Curzon the difficulty presented by the amount of indemnity on the basis of Articles VI and VII as this would lead to the British occupation of the Chumbi Valley for 75 years. He thought that this was not consistent with his instructions and the declaration of His Majesty's Government. Therefore, Brodrick authorised a declaration appended to the ratified convention to reduce the indemnity from 75 lakhs to 25 lakhs of rupees, one-third of the original amount. As for the British occupation of the Chumbi Valley, '[for the purpose of] fulfilment of provisions as to the trade marts, the Chumbi Valley is to be

to Tibet; $d$. No concessions for railways, roads, telegraphs, mining or other rights, shall be granted to any foreign Power, or the subject of any foreign Power. In the event of consent to such concessions being granted, similar or equivalent concessions shall be granted to the British Government; e. No Tibetan revenues, whether in kind or in cash, shall be pledged or assigned to any foreign Power, or to the subject of any foreign Power". FO 93/105/1, Convention between Great Britain and Tibet, Foreign Office Records.

${ }^{43} \mathrm{Wu}$ Fengpei (吴丰培), supra n.36, p 1195.

${ }^{44}$ Ibid, pp 1195-96.

${ }^{45}$ Ibid, pp 1198-99. 
occupied until the marts have been opened effectively for three years'. ${ }^{46}$ In the meantime, Brodrick's decision won the support of Parliament. In the House of Lords, Lord Reay held that the proper method of communication was with the Chinese authorities. In response to Curzon's description of China's suzerainty over Tibet as a 'constitutional fiction', Reay further pointed out that 'This strikes me as an extremely impolitic assertion that a situation which our Government had always recognised, which is founded on law, history, and tradition should be considered a constitutional fiction - extremely impolitic when we realize what suzerainty means to us in India...far from looking upon the suzerainty as a constitutional fiction, the home government looked upon Tibet as a province of China'. ${ }^{47}$ Lord George Hamilton stated that '... we have no desire either to declare a protectorate or permanently to occupy any portion of the country [Tibet]. Measures of this kind might, however, become inevitable if we were once to find ourselves committed to armed intervention in Tibet, and it is almost certain that, were the British mission to encounter opposition, questions would be raised which would have to be considered not as local ones concerning Tibet and India exclusively, but from an international point of view, as involving the status of a portion of the Chinese Empire' ${ }^{48}$ The Marquess of Ripon, the former Secretary of State for India and Viceroy of India, claimed that the British Government should 'not give an opportunity to any other Power to say that we are interfering with China or threatening the independence of any portion of her country. I know very well that His Majesty's Government have no intention whatever, according to their declarations - and I believe them to be perfectly sincere - of occupying Tibet, of annexing Tibet, or of interfering with the suzerainty of China over Tibet' ${ }^{49}$ It can be seen from the above opinions that London was dissatisfied with the situation created by the disobedience of its representative on the premise of recognising China's suzerainty over Tibet. Although there was no precise definition of suzerainty in the statements of the Members of Parliament, it is clear that Britain recognised Tibet as a part of China under the Chinese suzerainty. But what status did Britain hope to gain in Tibet through the conclusion of the Lhasa Treaty? The following part discusses the ambiguities of Sino-Tibetan relations caused by the Lhasa Convention.

\footnotetext{
${ }^{46}$ Li Tieh-Tseng, pp 98-9.

${ }^{47}$ See https://hansard.parliament.uk/Lords/1904-02-26/debates/9a20f726-69cb-4b1a-99b20b0e8e025474/TheMissionToTibet, Column 1117.

${ }^{48}$ Ibid.

${ }^{49}$ Ibid, Column 1137.
} 


\subsubsection{The Influence of the Lhasa Convention on Shaping Tibet's Status}

Seeing that the Lhasa Convention was the first treaty directly concluded by a Western Power and the Tibetans, some writers have argued that the conclusion of the convention means that Britain implicitly recognised Tibet as an independent sovereign State in international law. ${ }^{50}$ Other writers have asserted that the Lhasa Convention in fact turned Tibet into a British protectorate through its ambiguous provisions. ${ }^{51}$ This section first examines whether the act of concluding an agreement between Britain and Tibet was sufficient to recognise the latter's independent status. It then discusses the definition of protectorate in international law and whether the Anglo-Tibetan relations could be defined as a protectorate. The last part of this section examines the type of relationship created by the Lhasa Convention between Britain and Tibet if Tibet was neither an independent State nor a protectorate of Britain.

\subsubsection{Was Tibet an Independent State?}

According to Oppenheim, treaties are conventions or contracts between two or more States concerning various matters of interest. ${ }^{52} \mathrm{He}$ further pointed out that 'the right of making treaties is a mere competence attaching to sovereignty. A State possesses, therefore, treaty-making power only so far as it is sovereign. Full-Sovereign States may become parties to treaties of all kinds..... not-full Sovereign States, however, can become parties to such treaties only according to their competence to conclude. It is impossible to lay down a hard and fast rule concerning such competence of all not-full Sovereign States. Everything depends upon the special case' ${ }^{53}$ If it is believed that only sovereign states can conclude treaties in the sense of international law, then 'only a portion - generally less than 50 percent — of agreements that may be said to have the character of a "treaty" according to its legal definition are explicitly called "treaties" as such in their texts'. ${ }^{54}$ In fact, Great Britain had concluded a great number of agreements

\footnotetext{
${ }^{50}$ Michael C. Van Walt Van Praag, p 131. Tsepon Wangchuck Shakabpa, One Hundred Thousand Moons An Advanced Political History of Tibet Vol. 2, Brill, 2009, pp 681-82.

${ }^{51}$ Taraknath Das, British Expansion in Tibet, N.M. Raychowdhury \& Company, 1928, p 66; Li Tieh-Tseng, p 97.

${ }^{52}$ L. Oppenheim, International Law: A Treaties, Vol.1, London: Longmans, Greens and Co., 1905, p 517.

${ }^{53}$ Ibid, p 521.

${ }^{54}$ Edward Keene, The Treaty-Making Revolution of the Nineteenth Century, The International History Review, Volume 34, 2012, p 483.
} 
with the indigenous peoples of Africa and America throughout the nineteenth century. ${ }^{55}$ Although these agreements are called treaties with international characteristics by some legal scholars, it is often assumed that treaties between indigenous peoples and the British Crown are not international treaties according to the present conventional sense of the term, that is, instruments concluded between sovereign States. ${ }^{56}$ For example, in an early decision, the Supreme Court of Canada concluded that treaties between Indigenous peoples and the Crown were not international treaties but were sui generis treaties. ${ }^{57}$ In academia, Arnold McNair denied the international sense of the agreement made between a State and native princes or chiefs of peoples. ${ }^{58}$ In order to support his view, he cited the Island of Palmas arbitration, which held 'as regards contracts between a State or Company such as the Dutch East India Company and native princes or chiefs of peoples not recognized as members of the community of nations, they are not, in the international law sense, treaties or conventions capable of creating rights and obligations such as may, in international law, arise out of treaties. But on the other hand, contracts of this nature are not wholly void of indirect effects on situations governed by international law'. ${ }^{59}$ Similarly, although UN Special Rapporteur Miguel Alfonso Martinez in his report on indigenous treaties recognised the capacity of indigenous peoples to enter into international agreements, he admitted that 'a narrow definition of treaties and treaty-making would impede (or even preclude) any proper account of indigenous views on these issues, simply because of the widely held rationale that indigenous peoples are not "States" in the current sense of the term in international law'. ${ }^{60}$ From this point of view, it can be seen that regardless of whether such agreements were recognised as international treaties in nature, these indigenous peoples were not recognised as sovereign States according to international law at that time. This indicates that agreements with the title of treaty may not necessarily have been

\footnotetext{
${ }^{55}$ Agreement between Great Britain and the Chiefs of Old Calabar and the Delegates of Slaves of the Qua Plantations (Nigeria), Feb. 15, 1851, 106 CTS 183-1; Engagement between Great Britain and the Chiefs of New Calabar (Nigeria), Aug. 8, 1851, 106 CTS 183-4; Engagement for the Abolition of the Traffic in Slaves between Great Britain and the King and Chiefs of Dahomey (West Africa), Jan. 13,1852, 107. See William Thomas Worster, Relative International Legal Personality of Non-State Actors, note 64, Brooklyn Journal of International Law, Vol. 42, No. 1, 2016, p 217.

${ }^{56}$ Ibid. Also see Inge Van Hulle, Britain, West Africa and the formation of imperial international law (1807-1885), $\mathrm{PhD}$ dissertation of KU Leuven, Faculty of Law, 2016, pp 56-70; Brenda L. Gunn, Exploring the International Character of Treaties 1-11 and the Legal Consequences, Canada in International Law at 150 and Beyond Paper No. $5, \mathrm{p} 1$.

${ }^{57}$ Simon v The Queen, (1985) 2 SCR 387 at para 33, recite from Brenda L. Gunn, p 1.

${ }^{58}$ Arnold Duncan McNair, The Law of Treaties, Oxford University Press, Clarendon, 1961, p 52.

${ }^{59}$ Island of Palmas Case (United States v The Netherlands), Award, 4 April, 1928, 2 RIAA 829 (PCA) at p 858.

${ }^{60}$ See Miguel Alfonso Martínez, Study on treaties, agreements and other constructive arrangements between States and indigenous populations, Final report, 1999, para 55.
} 
concluded between sovereign States. Therefore, the act of contracting itself does not prove that one or both of the contracting parties are independent sovereign States.

With regard to the Lhasa Convention, as an ethnic minority in relations with the Qing Empire, can the Tibetans also be regarded as an indigenous people in international law? According to Katja Göcke, indigenous peoples are those who consider themselves distinct from other sectors of the societies and are determined to preserve, develop and transmit to future generations their ancestral territories. ${ }^{61}$ Their self-identification as the basis of their continued existence as peoples constitutes the key criteria for indigenous peoples. The other objective criterion for a group to be regarded as indigenous refers to its special relationship with its ancestral lands. ${ }^{62}$ This connection is what defines indigenous peoples and distinguishes them from minorities. According to Lucia Fresa, a minority exists only in relation to a majority within the State, while an indigenous group does not need any numerical evidence to be characterised as such. In some cases, indigenous people may constitute majorities in some States. ${ }^{63}$ This shows that indigenous peoples and minorities are not two exclusive concepts but overlap in some cases. As for the Tibetans, they have lived for generations on their land, now known as the Qinghai-Tibet Plateau, maintaining their own language, culture and religious beliefs. In this sense, they were not only indigenous people in Tibet but also ethnic minority in relation to the Qing Empire. In this sense, the Lhasa Convention concluded between the British and the Tibetans can be considered as an agreement between a State and an indigenous people, and from this perspective, the conclusion of the Lhasa Convention itself cannot be used as evidence that Britain implicitly recognised Tibet as an independent State.

According to Michael C. Van Praag, 'the conclusion of the treaty constituted implicit recognition by Britain of Tibet as a State and a subject of international law, and of the Dalai Lama's government as the legitimate government of Tibet, competent to represent that country internationally as well as to conclude treaties'. ${ }^{64} \mathrm{He}$ also cited the conclusion of the Tibet-Nepal Convention of 1856 as evidence that Nepal recognised

\footnotetext{
${ }^{61}$ Katja Göcke, Indigenous Peoples in International Law, Göttingen University Press, 2013, pp 18-9.

${ }^{62}$ Ibid. Also see Final Report of the Committee on the Rights of Indigenous Peoples, International Law Association, Sofia Conference, 2012, pp 2-3.

${ }^{63}$ Lucia Fresa, A new interpretation of the term 'indigenous people': what are the legal consequences of being recognised as 'minorities' instead of as 'indigenous people' for the indigenous people of the world? See http://www.studiperlapace.it/documentazione/fresa.html\#TWO.

${ }^{64}$ Michael C. Van Walt Van Praag, p 131.
} 
Tibet's statehood and international personality because 'the commercial, diplomatic, and extraterritorial and judicial privileges conceded to Nepal in the 1856 treaty presupposed the full exercise of sovereignty by the Government of Tibet' ${ }^{65}$ In fact, these two treaties did share many similarities. For example, they were all outcomes of war and they were concluded between the Tibetans and the foreign governments. However, what he omitted was the role the amban played in the negotiation between the Tibetans and the Nepalese. When Nepal invaded Tibet in 1855, the Qing Government was focussed on suppressing the Taiping Rebellion and it was eager to end the war in Tibet as soon as possible. Therefore, it instructed the amban to mediate and negotiate a peace treaty with the Nepalese. In this sense, the Qing Government implicitly allowed the Tibetans to conclude a treaty with the Nepalese under the supervision of the amban. More importantly, the Qing Government did not express any opposition to the Tibet-Nepal Convention of 1856. Therefore, the conclusion of this convention could not properly prove that the Tibetan government had the capacity to independently exercise its sovereignty.

Although there were some similarities between the conclusion of the Tibet-Nepal Convention of 1856 and the Lhasa Convention of 1904, there were also great differences between them. As mentioned previously, the Qing Government explicitly instructed the amban not to sign the draft and to persuade the Tibetans not to sign it if this was possible, which was equal to refusing to retroactively recognise the Lhasa Convention. According to the reactions of Brodrick and parliament members, London also regarded Tibet as a part of China rather than an independent State. Article I of the Lhasa Convention itself stipulated that 'the Government of Tibet engages to respect the Anglo-Chinese Convention of 1890...'. However, if Britain regarded Tibet as an independent State, then it was unnecessary to require Tibet to abide by treaties it did not enter into before. For these reasons, the conclusion of the Lhasa Convention could not constitute British recognition of Tibet's independence.

\subsubsection{Was Tibet a State Under British Protection?}

\footnotetext{
${ }^{65}$ Ibid., p 128.
} 
Even though the Lhasa Convention did not confer on Tibet any independent State status, some scholars have argued that the articles of the Convention would have made Tibet a British protectorate through its ambiguous wording. ${ }^{66}$ According to Li Tieh-Tseng, Britain imposed heavy restrictions on Tibet's external relations and defence through Article IX. The indemnity stipulated in Article VI not only would have reduced Tibet to a state of financial vassalage to British India for three generations but also might have given the British occasion for interference in the affairs of Tibet. As for Article VII, the military occupation of the Chumbi Valley would provide the British 'a clear run into Tibet' ${ }^{67}$ He thus argued that the Lhasa Convention practically turned Tibet into a protectorate of Great Britain because the latter had created a kind of international guardianship over Tibet's external affairs.

Protectorate, as a conception that lacks juristic precision, essentially means that a weak State surrenders itself by treaty into the protection of a strong State in such a way that it transfers the management of all its important international affairs to the protecting State. ${ }^{68}$ Through such a treaty, the relation between them is called a protectorate. The protecting State is internationally the superior of the protected State, and the latter, with the loss of the management of its more important international affairs, has lost its full sovereignty. But it is characteristic of the protectorate that the protected State always has and retains in some part a position of its own within the Family of Nations and that it is always in some part an international person and a subject of international law. ${ }^{69}$ In this sense, a protected State should be a fully sovereign State before the conclusion of a treaty of protectorate. For example, the conclusion of the Treaty of Fez of 1912 made Morocco a French protectorate, although it remained a sovereign State as confirmed by the International Court of Justice in $1952 .{ }^{70}$ However, concerning the case of the Lhasa Convention, Tibet was never regarded as a fully sovereign State either by the British or the Chinese. For this reason, Tibet could not be a British protectorate through the Lhasa Convention.

\footnotetext{
${ }^{66}$ Taraknath Das, supra n.51, p 66; Li Tieh-Tseng, p 97.

${ }^{67}$ Li Tieh-Tseng, Ibid.

${ }^{68}$ L. Oppenheim, supra $\mathrm{n} .52, \mathrm{p} 137$.

${ }^{69}$ Ibid., p 138.

${ }^{70}$ Bedjaoui, Mohammed, International Law: Achievements and Prospects, Nijhoff Publishers, 1991, pp 51-2; Capaldo, Giuliana Ziccardi, Repertory of Decisions of the International Court of Justice (1947-1992), Nijhoff Publishers, 1995, p 453.
} 


\subsubsection{Tibet as the British Sphere of Influence}

Although the text of the Lhasa Convention did not directly indicate the status of Tibet, the term 'foreign Power' mentioned in Article IX seemed to create uncertainty for SinoTibetan relations. What was the scope of 'foreign Power'? Should China be included in foreign power? With no clear answer from Article IX, Younghusband's statement to some extent might solve this question. In order to explain the draft to the Tibetans, he claimed that by Article IX the British 'had not the least desire to supplant China in the suzerainty of Tibet. The Chinese suzerainty was fully recognized in the adhesion agreement, which it was proposed the Resident (the amban) should sign on behalf of the Chinese Government, and China was not included in the term 'Foreign Power'. ${ }^{71}$ Later, Younghusband addressed a note to the amban confirming the exclusion of China from the term 'Foreign Power'. ${ }^{72}$ Based on these statements, Younghusband defined Sino-Tibetan relations as Chinese suzerainty over Tibet, albeit with no further explanation on the definition of 'suzerainty'. This was the first time that the British used this term to describe the status of Tibet. With the benefit of hindsight, this term was equal to internal autonomy of Tibet without Chinese interference; however, it apparently contradicted the Qing Government's claim of sovereignty over Tibet. ${ }^{73}$ Given the fact that the phrase of 'Chinese suzerainty over Tibet' was first stipulated in the Anglo-Russian Convention of 1907, a detailed discussion on this concept is included in section 4.3 with a view to examining whether China had sovereignty or suzerainty over Tibet before 1912.

Even though the Lhasa Convention brought ambiguities to Tibet's status, the Russian factor behind the British expedition to Tibet and the restrictions imposed by Articles VII, VIII and IX of the Lhasa Convention reveals that the purpose of the British was to bring Tibet into their sphere of influence to prevent other Powers from getting involved. ${ }^{74}$ Therefore, the Lhasa Convention naturally aroused dissatisfaction from other Powers. Russia, which was most opposed to the Lhasa Convention, protested that

\footnotetext{
${ }^{71}$ Francis E. Younghusband, supra n.35, p 286.

${ }^{72}$ Li Tieh-Tseng, p 104.

${ }^{73}$ See Article II of the draft of Simla Convention of 1914 in FO/535/17, No.231, Enclosure 8.

${ }^{74}$ Article VII stipulated that the British shall continue to occupy the Chumbi Valley until the indemnity has been paid; Article VIII stipulated that the Tibetan Government shall raze all forts and fortifications and remove all armaments which might impede the course of free communication between the British frontier and Gyantse and Lhasa; Article IX prevented Tibet from having relations with any other foreign powers without the British consent. See FO 93/105/1, Convention between Great Britain and Tibet, Foreign Office Records.
} 
the treaty constituted the establishment of a British protectorate over Tibet because Article IX had given them the impression that the British were excepted from the prohibitions of this Article. ${ }^{75}$ Russia also pointed out that the British occupation of the Chumbi Valley and the British construction of a telegraph line from the India border to Gyantse proved that Great Britain considered that Article IX did not apply to herself. ${ }^{76}$ In addition, Germany indicated to China that Germany would not be bound by Article IX because it gave the British the status of most-favoured-nation in Tibet. ${ }^{77}$ Consequently, the German Minister in Peking, Baron Mumm, did his best to persuade the Qing Government to oppose the Lhasa Convention. ${ }^{78}$ The United States, France and Italy also remarked on the most-favoured-nation implications of the Treaty. ${ }^{79}$ These Western Powers insisted that all the existing agreements which contained one-sided most-favoured-nation clauses with China would be as applicable in Tibet as they were in Shanghai. For this reason, it may be inferred that they were inclined to recognise Tibet as a part of China.

Because of the Qing's failure to fulfil its treaty obligations in Tibet and the concerns about Russia's expansion in this area, the British launched a military expedition to Tibet in 1903. As a consequence of this expedition, Younghusband concluded an agreement with the Tibetans without the signature of the Amban. This made the legal nature of this agreement uncertain and questionable. Considering that neither Britain nor China recognised Tibet as a fully sovereign State, the conclusion of the agreement itself could hardly constitute implicit recognition of Tibet as a sovereign State and a subject of international law by Britain. It might also be hard to say that Tibet had become a British protectorate through the Lhasa Convention because, according to the theory of protectorate at that time, the protected State should be a full sovereign State before the treaty of protectorate is concluded. In a note that Younghusband sent to the amban, he for the first time defined the Sino-Tibetan relations as Chinese suzerainty over Tibet. This description had a far-reaching influence as it would profoundly affect the British position on Tibet's status for the next half-century. At the same time, the Qing Government did not agree that its authority in Tibet was a kind of suzerain right; on the

\footnotetext{
${ }^{75} \mathrm{FO} / 17 / 1752$, Foreign Office Memo on the Agreement with Tibet, dated of 25 September, 1904.

${ }^{76} \mathrm{FO} / 17 / 1752$, Lansdowne to Hardinge, date of 9 August, 1905.

${ }^{77}$ Because (d) of Article IX regulated that in the event of consent to concessions for railways, roads, telegraphs, mining or other rights being granted to foreign powers, similar or equivalent concessions shall be granted to the British Government.

${ }^{78}$ Alastair Lamb, p250.

${ }^{79}$ Peter Fleming, Bayonets to Lhasa: The British Invasion of Tibet, Tauris Parke, 2012, p 247.
} 
contrary, it claimed that the Qing had sovereignty over Tibet. In the aftermath, these two opposite opinions on the status of Tibet emerged and confronted each other throughout the first half of the 20th century. In any event, what is clear from articles of the Lhasa Convention is that the British successfully brought Tibet into its sphere of influence. In the next section, the Chinese adherence to the Lhasa Convention in a new Sino-British Convention of 1906 is discussed to explain how the Lhasa Convention was converted from an agreement with uncertain validity to a 'treaty' in the international legal sense.

\subsection{The Sino-British Convention of 1906}

In light of the strong opposition to the Lhasa Convention from not only China but also other Powers, the British Government realised that this agreement might be difficult to enforce. Therefore, Britain saw the necessity of Chinese adherence to the Convention of 1904. The Qing Government was also keen to renegotiate with the British on a modification of this agreement. Britain and China thus sent representatives to Calcutta and Peking for negotiations. The Chinese Representative Tang Shao-Yi (唐绍仪) initially insisted that Article IX of the Treaty of Lhasa should be revised to clarify the British position in Tibet. On Sino-Tibetan relations, he insisted that Chinese sovereignty in Tibet should be recognised. ${ }^{80}$ But the British representatives only agreed to recognise Chinese suzerainty as the appropriate expression of their relationship with Tibet. Facing British opposition to the mention of sovereignty, Tang put forward that the Chinese Government should be the sole intermediary in all communications between India and Tibet in the amendment of Article IX ${ }^{81}$ The British claimed that the only way they would agree to not use the term suzerainty in the text of the adhesion agreement would be the acceptance by China of all terms of the Lhasa Convention except for Article IX. As a result of China's concession, on 27 April 1906, the Convention between Great Britain and China with respect to Tibet was signed in Peking, and the Lhasa Convention of 1904 was attached to the Convention as an annex. ${ }^{82}$ This section analyses the role of

\footnotetext{
${ }^{80}$ Tang cited the evidences that the investiture of the Dalai and Panchen Lamas, the appointment of Kablons and local Tibetan officials were owned by the Chinese Court, and the supervision of the native troops was owned by the amban. Tieh-tseng Li, p 109.

${ }^{81}$ Lu Xingqi, Xizang Jiaoshe Shiyao (important diplomatic dealings concerning Tibet), published by Mongolian and Tibetan Affairs Commission, pp 25-27.

${ }^{82}$ Charles Bell, Tibet Past and Present, Oxford University Press, 1927, p 287.
} 
this Convention in shaping Sino-Tibetan relations as well as the relationship between the Convention of 1906 and the Lhasa Convention of 1904.

4.2.1 The Sino-British Convention of 1906 in Shaping the Qing's Authority in Tibet

The main content of the Convention of 1906 included:

(a) Both parties confirmed the text of the Lhasa Convention and attached it to the Convention as an annex;

(b) Britain engaged not to annex Tibetan territory or to interfere in the administration of Tibet. China also undertook not to permit any other foreign State to interfere with the territory or internal administration of Tibet; and

(c) China was excluded from 'foreign Power' stipulated in Article IX (d) of the Lhasa Convention. ${ }^{83}$

Concerning the Qing Government's role in Tibet, there are at least four points contained in Article II. ${ }^{84}$ First, Great Britain affirmed that Tibet was not a British territory; second, Britain promised China not to annex Tibet; third, Britain also promised China not to interfere in the administration of Tibet; and last, China was requested not to permit any other foreign State, which mainly aimed at Russia, to interfere with the territory or internal administration of Tibet. ${ }^{85}$ But was China allowed to manage Tibet's internal affairs? The key to this question may lie in how Article IX of the Lhasa Convention of 1904 is explained.

Through Article IX, the British imposed heavy restrictions on the external and internal affairs of Tibet. But apart from Younghusband's statement during the negotiation, the Article itself did not make it clear whether China was excluded from the notion of foreign Power. This question might need to be clarified with theories on the interpretation of treaties. As a customary rule, preparatory work for treaties may be used as a supplementary means of interpretation because the conclusion of a treaty is a complete process; accordingly, a scientific interpretation of the treaty must take the

\footnotetext{
${ }^{83}$ See Articles I, II, III of the Sino-British Convention of 1906 in Charles Bell, Tibet Past and Present, p 287.

${ }^{84}$ Article II stipulated that 'the Government of Great Britain engages not to annex Tibetan territory or to interfere in the administration of Tibet. The Government of China also undertakes not to permit any other foreign State to interfere with the territory or internal administration of Tibet'.

${ }^{85}$ Deng Lie, Study on the Historical and Legal Status of Tibet in International Law, Chinese National Social Science Fund Project, 2013, pp 49-51.
} 
whole process into consideration, and the development of the negotiations of the treaty would logically become a part of this process. Resorting to preparatory work or travaux preparatoires for the purpose of interpreting a treaty has been supported by many publicists and the relevant practices of States over the years. ${ }^{86}$ Younghusband, as the British representative, might be the one who had knowledge of the intention of the Lhasa Convention and his statements and notes during the negotiations could thus be considered as the preparatory work in the treaty-making process. In this same spirit, since China was not a foreign Power, it was naturally permitted to intervene in Tibetan affairs, such as building roads, railways and collecting taxes. ${ }^{87}$ Article III of the 1906 Convention further clarified that the concessions which were mentioned in Article IX (d) of the Lhasa Convention were denied to any State other than China. ${ }^{88}$ From this perspective, the Qing Government was not only responsible for Tibet's external affairs but also not excluded from intervening in Tibet's internal affairs. Therefore, the SinoBritish Convention of 1906 was inconsistent with the term 'suzerainty' concerning the internal autonomy of Tibet insisted upon by the British.

4.2.2 The Relationship Between the Convention of 1906 and the Lhasa Convention of 1904

As discussed earlier, the legal validity of the Lhasa Convention is questionable. The conclusion of the 1906 Sino-British Convention provided a possible answer to this question. According to the preamble of the treaty, 'His Britannic Majesty and His Majesty the Emperor of China have resolved to conclude a Convention on this subject', and this subject could only refer to the Chinese adherence to the Lhasa Convention of

\footnotetext{
${ }^{86}$ Hyde argued "declarations of their plenipotentiaries, insofar as they indicate the sense in which the terms of a treaty are employed, are valuable not merely because they are enlightening, but also because they may be safely entrusted to the consideration of judges of international tribunals, or to ministers of state", see Charles Cheney Hyde, Concerning the Interpretation of Treaties, American Journal of International Law, Volume 3, Issue 1, 1909, p 54. In practice, international arbitral tribunals have in fact frequently resorted to travaux preparatoires when interpreting treaties. In the Island of Timor Case, the Permanent Court of Arbitration was requested to interpret Article 3 of the Convention between the Netherlands and Portugal of 1904, which described the method of drawing a boundary line between the Dutch and Portuguese possessions in the Island of Timor. In doing so the tribunal carefully reviewed the discussions of the Dutch and Portuguese plenipotentiaries during the negotiations of the Convention, and based its decision thereon. See Boundaries in the Island of Timor, Netherlands v Portugal, Award by Permanent Court of Arbitration, 25 June 1914.

${ }^{87}$ Article IX (b) of Lhasa Convention prohibited foreign Power to intervene in Tibetan affairs.

${ }^{88}$ Article III of the Sino-British Convention of 1906 stipulated that 'the Concessions which are mentioned in Article IX (d) of the Convention concluded on September 7, 1904 by Great Britain and Tibet are denied to any State or to the subject of any State other than China, but it has been arranged with China that at the trade marts specified in Article II of the aforesaid Convention Great Britain shall be entitled to lay down telegraph lines connecting with India'.
} 
1904. Article I further stipulated that China and Britain confirmed the Lhasa Convention as an annex to the current Convention, and both of the High Contracting Parties engaged to secure the fulfilment of its terms. These two provisions are crucial to an understanding of the relationship between the 1906 Sino-British Convention and the 1904 Anglo-Tibetan Convention.

According to Article 31 of the Vienna Convention on the Law of Treaties, 'a treaty shall be interpreted in good faith in accordance with the ordinary meaning to be given to the terms of the treaty in their context and the light of its object and purpose' ${ }^{89}$ Although this rule was not compiled with in the Convention until the 1960 s, it did reflect a customary rule that the terms of a treaty cannot be thoroughly comprehended unless they are read in the light of the design which prompted its conclusion. This view has not only been accepted by many publicists but has also been supported by the practices of States. ${ }^{90}$ The objective of the contracting parties to the 1906 Convention was to extend the obligations of the Tibetans under the 1904 Convention to the Qing Government. For China, the Qing Government's agreement to sign the Convention of 1906 indicated that it retroactively recognised the validity of the Lhasa Convention signed two years earlier by the Tibetans. ${ }^{91}$ For Britain, the conclusion of the 1906 Convention meant that the British agreed to the Qing Government as the bearer of the Lhasa Convention. In fact, when the Convention of 1906 was signed in Peking, the British Government immediately consented to let the Qing Government pay the indemnity which needed to be paid by Tibetans under the 1904 Convention, and soon after China paid the last instalment in 1908, the British military evacuated from the Chumbi Valley. Through China's ratification, the 1904 agreement had been transformed from a questionable instrument into a valid treaty signed by the Tibetans and implemented jointly by the Qing Government and the Tibetans.

\footnotetext{
${ }^{89}$ https://legal.un.org/ilc/texts/instruments/english/conventions/1_1_1969.pdf.

${ }^{90}$ According to Vattel, 'the intention furnishes the true matter of the convention......A violation of the treaty is rather a deviation from the intention which it sufficiently manifests, than from the terms in which it is worded: for, the terms are nothing without the intention by which they must be dictated'. See Emer de Vattel, the Law of Nations, Philadelphia, 1844, p 249. As for the practice of State, in the case of Honduras v. Salvador and Guatemala of 1908, the Central American Court of Justice took account of the general purpose behind the treaty establishing the court in interpreting the provision thereof that its jurisdiction should extend to cases in which 'the respective foreign offices should have been unable to reach an agreement'. Honduras v. Salvador and Guatemala, the American Journal of International Law, Vol. 3, No. 3, 1909, pp 729-36.

${ }^{91}$ Xiang Min (向敏), An analysis of international law in the study of the validity of the McMahon Line by Western authoritative scholars (西方权威学者麦克马洪线效力问题研究的国际法分析), dissertation of Zhongnan University of Economics and Law, 2020, p 12.
} 
This discussion shows that the Sino-British Convention of 1906 indirectly recognised the Qing Government's sovereignty over Tibet, although the British Government insisted on using suzerainty to define the Sino-Tibetan relations. By concluding the 1906 Convention, the Qing Government gave its retroactive recognition to the Lhasa Convention, which transformed it from a questionable instrument into a valid treaty in international law. In the next section, the 1907 Anglo-Russian Convention relating to Tibet is studied to reveal its influence on shaping the status of Tibet. As the AngloRussian Convention was the first convention which explicitly described Sino-Tibetan relations as a suzerain right, the concept of suzerainty in international law is also examined to primarily explain whether the Qing Government possessed sovereignty or suzerainty over Tibet before its collapse in 1911.

\subsection{The Anglo-Russian Convention of 1907}

After the Sino-Tibetan Convention was concluded in 1906, the situation in Europe dramatically changed. With the rapid rise of German military power, Britain and Russia were increasingly sceptical of Germany's imperialistic motives. It was in this context that Britain and Russia decided to resolve their confrontations in Asia and an AngloRussian Convention relating to Persia, Afghanistan and Tibet was signed on 31 August 1907 in St. Petersburg. The following discussion analyses the provisions of this treaty and examines its influence in shaping Sino-Tibetan relations.

4.3.1 The Content of the 1907 Anglo-Russian Convention and its Effects on the SinoTibetan Relations

The main content of the 1907 Convention relating to Tibet included:

(a) Great Britain and Russia engaged to respect the territorial integrity of Tibet and to abstain from all interference in the internal administration;

(b) By admitting the suzerainty of China over Tibet, Great Britain and Russia engaged not to enter into negotiations with Tibet except through the intermediary of the Chinese government;

(c) Great Britain and Russia engaged not to send Representatives to Lhasa; 
(d) Great Britain and Russia engaged not to obtain any concessions for railways, roads, telegraphs, mines and revenues or other rights in Tibet. ${ }^{92}$

With regard to Sino-Tibetan relations, similar to those demonstrated in the 1906 Convention, three points can be inferred from the commitment of Britain in the preamble and Article I of the Convention. ${ }^{93}$ First, Great Britain affirmed that Tibet was not British territory. Second, Britain promised Russia not to annex Tibet. Third, Britain promised Russia not to interfere in the administration of Tibet. As for the commitments by Russia, two points can be inferred. One is that Russia confirmed Tibet was not Russian territory. The other is that Russia promised Britain not to annex Tibet and not to interfere in the internal administration of Tibet. ${ }^{94}$ According to Article II and III of the 1907 Convention, Britain and Russia also promised each other not to have direct communication with Tibet and not to send representatives to Lhasa. ${ }^{95}$ Britain and Russian could only establish communication with Tibet through the intermediary of the Qing Government. These provisions confirmed that China was the only Power in charge of the external affairs of Tibet, and they were undoubtedly beneficial to China's claim of sovereignty over Tibet. But at the same time, the preamble and Article II only recognised the suzerain rights of China in Tibet, which was contrary to China's claim. For this reason, the expression of suzerainty constituted a legal burden which China was unwilling to admit. Since China was not a contracting party to the 1907 AngloRussian Convention, could the matters stipulated within it affect the Qing Government's sovereign claim over Tibet?

Usually, a treaty does not create either obligations or rights for a third State without its consent. The rule of pacta tertiis nec nocent nec prosunt not only has been accepted by publicists but also supported by State practices as customary international law. ${ }^{96}$ Since

\footnotetext{
${ }^{92}$ Charles Bell, supra n.82, p 289.

${ }^{93}$ The preamble of the Anglo-Russian Convention of 1907 regulated that ' ...the Governments of Great Britain and Russia recognizing the suzerain rights of China in Tibet, and considering the fact that Great Britain, by reason of her geographical position, has a special interest in the maintenance of the status quo in the external relations of Tibet, have made the following arrangement...'; Article I stipulated that 'the two High Contracting Parties engage to respect the territorial integrity of Tibet and to abstain from all interference in the internal administration'.

${ }^{94}$ Deng Lie, supra n.85, pp 49-51.

${ }^{95}$ Article II. In conformity with the admitted principle of the suzerainty of China over Tibet, Great Britain and Russia engage not to enter into negotiations with Tibet except through the intermediary of the Chinese Government... Article III. The British and Russian Governments respectively engage not to send Representatives to Lhasa.

${ }^{96}$ For example, the United States, while acquiescing in the provisions of Article I of the Convention of London of 1841 which closing the Bosporus and Dardanelles to foreign war ships, maintain that since it was not a party to the Treaty, thus this obligation was not binding upon it, and its acquiescence must be considered as simply an act of grace on its part. See Moore, A Digest of International Law, Vol. 1, Washington: Government Printing Office, 1906, p 664-8. Likewise, In the case relating to the Territorial Jurisdiction of the International Commission of the River
} 
China was not a contracting party and the term suzerainty constituted a derogation to the Chinese sovereign claim over Tibet, it had no legally binding force on China. It is not hard to understand the principle of not imposing obligations on a third State without its consent, but the rule is less absolute and settled in respect to the creation of rights in favour of third States. Generally, if a treaty contains a provision which is expressly for the benefit of a third State, such State is entitled to claim the benefit of that provision so long as the provision remains in force between the parties to the treaty. ${ }^{97}$ This principle was well reflected in the dispute between Prussia and Denmark on the referendum of Schleswig. ${ }^{98}$ As for the Anglo-Russian Convention of 1907, Article II explicitly stipulated that both contracting parties promised not to enter into negotiations with Tibet except through the intermediary of China. This provision was beneficial to China, especially considering that the Qing's influence in Tibet had been declining since the 1850s. Henceforth, China's right to exercise its external sovereignty over Tibet was confirmed by Britain and Russia.

In conclusion, the Anglo-Russian Convention of 1907 explicitly demonstrated that external sovereignty over Tibet was in the hands of the Qing Government. Therefore, it was tantamount to denying that Tibet enjoyed the status of an independent sovereign State. However, the term of suzerainty stipulated in Article II also produced considerable ambiguity on the status of Tibet. The following discussion examines the definition of suzerainty in international law and whether the Qing Government possessed sovereignty or suzerainty over Tibet.

\footnotetext{
Oder, the Permanent Court of International Justice concluded that since Poland had not ratified the Barcelona Convention on Freedom of Transit of 1921, thus the claimers could not invoke the Convention against Poland. See the Territorial Jurisdiction of the International Commission of the River Order - United Kingdom, Czechoslovakia, Denmark, France, Germany, Sweden v. Poland, PCIJ Series A no. 23. Also see Oleh Muniroh Rahim, International Law and Third Parties, Opinio Juris, Volume 1, January, 2010, p 36. See also Anzilotti, Cours de Droit International, Gidel trans, 1929, p. 414.

${ }^{97}$ Ibid.

${ }^{98}$ Article 5 of the Treaty of Prague of 1866 between Austria and Prussia stipulated that the Emperor of Austria ceded to the King of Prussia the Duchies of Holstein and Schleswig, subject to the reservation that if the population of the northern districts of Schleswig should by a referendum vote in favor of a union with Denmark they were to be ceded to that country instead of to Prussia. That article was abrogated by a mutual agreement between Austria and Prussia in 1878, without the referendum having been held. On April 16,1870, the Danish Minister at Paris addressed a letter to the German Minister maintained that although Denmark was not a party to the treaty, Article 5 constituted an integrity of the Treaty, thus Prussia was under an obligation to Denmark to hold the referendum. Finally, the Government of Prussia had itself officially brought to the knowledge of the King of Denmark the engagement which it had undertaken to retrocede Northern Schleswig to Denmark. See Viktor Bruns, Fontes Juris Gentium: A Digest of the Diplomatic Correspondence of the European States From 1856 to 1871, Series B, Part 1, Berlin: Heymanns, $1933, \mathrm{p} 754$.
} 


\subsubsection{Suzerainty in International Law}

In order to gain a basic understanding of suzerainty, this part first introduces the theoretical origin of this concept. The discussion then moves to illustrate the discrepancy between its theoretical definition and practices in the world. This includes the first appearance of suzerainty put forward by the Western Powers in the Ottoman Empire in the nineteenth century and its subsequent development. The practice of suzerainty in Africa and south Asia is also studied to reveal its differences between theory and practice. After exploring the above subjects, this part attempts to explain that it is difficult to give a precise definition of suzerainty in international law.

As a concept closely related to sovereignty, suzerainty is a term which originally was used to describe the relationship between the feudal lord and his vassal. The latter owed allegiance to the suzerain ruler, had to pay tribute, to provide military support and was, in turn, entitled to the protection of suzerain ruler. ${ }^{99}$ From this perspective, the emergence of suzerainty in mediaeval times preceded the concept of sovereignty which was put forward in the sixteenth century. But the modern use of suzerainty can be traced back to the early nineteenth century when Western Powers used this term to describe the relations between the Ottoman Empire and its not-fully sovereign principalities. Before discussing suzerainty, it is necessary to have a general understanding of the concept of sovereignty in international law. Sovereignty was first introduced into political science in the late sixteenth century by Bodin who described it as absolute and supreme power without any restriction. ${ }^{100}$ Similar to Bodin, almost all writers in the sixteenth and seventeenth century held that sovereignty is not divisible and contains the integration of all powers, whether in the hands of a monarch or the people itself in a Republic. ${ }^{101}$ When it came to the eighteenth century, the fact that hundreds of member States of the Holy Roman Empire had practically gained a varying degree of independence since the Westphalian Peace led to some writers noticing the distinction between full sovereignty and imperfect sovereignty. ${ }^{102}$ In the meantime, the transition of the United States of America from a Confederation of States to a Federal State

\footnotetext{
${ }^{99}$ Alexandrowicz Alexander, The Legal Position of Tibet, American Journal of International Law, Volume 50, Issue 2, 1956, pp 265-66.

${ }^{100}$ Jean Bodin, edited by Julian H. Franklin, On sovereignty: Four chapters from the Six books of the commonwealth, Cambridge University Press, 1992, p 1-2.

${ }^{101}$ Oppenheim, supra n.52, pp 104-105.

${ }^{102}$ Ibid.
} 
indicated that the division of sovereignty between the Sovereign Federal State and the Sovereign Member-States appeared. In the nineteenth century, Switzerland declared in their constitutions that the member States of the federation remained sovereign States, which indirectly recognised the divisibility of sovereignty. ${ }^{103}$ According to the theory of divisibility, sovereignty can be divided into external sovereignty and internal sovereignty based on its function. Correspondingly, States can also be categorised into fully sovereign States and not-fully sovereign States depending on whether they have both external and internal sovereignty.

In this context, the concept of suzerainty was revived in the early eighteenth century by Western Powers to define the relationship between the Ottoman Empire, which was considered as a suzerain State with full sovereignty, and its Christian principalities, which were considered as vassal States with internal sovereignty. ${ }^{104}$ The relation between a vassal State and a suzerain State was established on the assumption that the sovereignty of the vassal State could be divided into internal and external aspects. Theoretically speaking, in a vassal-suzerain relation, the external sovereignty of the vassal State is absorbed by the suzerain State though it retains internal sovereignty which the latter is under a duty to respect. With regard to the status of a vassal State deprived of external sovereignty, it has no position of its own in the Family of Nations. For this reason, the vassal State remains a portion of the suzerain State which entirely represents it in relations with other nations. ${ }^{105}$ But even in theory, the concept of suzerainty lacks juridical precision because the relation between the suzerain and vassal depends on its own merits. Therefore, a general rule regarding the position of a vassal State within the Family of Nations cannot be laid down. ${ }^{106}$ Unlike a protected State which should be fully sovereign before the treaty of protectorate is concluded, a vassalsuzerain relation is not necessarily derived from treaties; instead, it is usually formed based on a historical conquest of the vassal State by the suzerain State.

However, this theoretical perception did not necessarily reflect the practices of States during the nineteenth and twentieth century. As mentioned above, the term 'suzerainty'

\footnotetext{
${ }^{103}$ The Swiss Federal Constitution of 1874 states that '(I)Together, the peoples of the 23 sovereign Cantons of Switzerland united by the present alliance...... form the Swiss Confederation; (III)The Cantons are sovereign insofar as their sovereignty is not limited by the Federal Constitution and, as such, exercise all rights which are not entrusted to the federal power'.

${ }^{104}$ James Crawford, the Creation of States in International Law, Oxford: Clarendon Press, 1979, p. 209; W. Kelke, Feudal Suzerains and Modern Suzerainty, Law Quarterly Review, Vol. 12, Issue 3, 1896, p 223.

${ }^{105}$ Alexandrowicz, supra n. 99, p 266.

${ }^{106}$ Oppenheim, pp 133-4.
} 
was first used in the nineteenth century to describe the relationship between the Ottoman Empire and its Christian principalities which were not under the former's direct control. Before their mutual relation was described as a suzerain relation by the Western Powers, the Ottoman government had already demanded some obligations from those non-Muslim principalities, such as Ionia, Wallachia and Moldavia. These obligations mainly involved paying tax to Istanbul, rendering various official and unofficial tributes to the Sultan, supplying men and materials in support of the Empire's military campaigns, full cooperation with the Ottoman Government's diplomatic policies and recognition of newly appointed princes by the Ottoman Emperor. The principalities were guaranteed security and allowed by the Ottoman government to maintain existing institutions of governance and autonomy in their internal administration, such as the election of their own princes. ${ }^{107}$ These rights and obligations are believed to constitute the early basis for vassal-suzerain relations within the Ottoman Empire before the intervention of the Western Powers.

With the expansion of Russia's influence in these Christian principalities after the seventeenth century, the political affiliations between the Ottoman Government and these principalities had significantly declined. The Ottomans' suzerain rights first appeared in the Treaty of Constantinople of 1800, when the Ottoman Empire and Russia placed the Republic of Ionia under Ottoman suzerainty. ${ }^{108}$ But the content of Ottoman suzerainty here was far from clear considering that the islands were under de facto Russian occupation. The significance of the case of Ionia was that it set a precedent in the Balkans. The outbreak of the Greek War of Independence in the 1820s led Britain, Russia and France to attempt to stop the war by giving Greece autonomous status. In 1827, these three Powers concluded the Treaty of London to set the status of Greece. According to Article II of the treaty, the Greeks shall hold under the Sultan as under a suzerain lord. As a consequence of this suzerainty, they would pay to the Ottoman Empire an annual tribute, the amount of which would be fixed once and for all by mutual agreement. They would be governed by authorities which they would choose

\footnotetext{
${ }^{107}$ Mayuzumi Akitsu, The Appearance of Vassal States and "Suzerainty" in the Ottoman Empire: The Case of Wallachia and Moldavia, in A World History of Suzerainty: A Modern History of East and West Asia and Translated Concepts, edited by Takashi Okamoto, Toyo Bunko, 2019, pp 26-7.

${ }^{108}$ The Article I of the treaty stipulated that "l'empereur Ottoman et ses successeurs étant suzerains de la susdite république, c'est-à-dire seigneurs, princes et protecteurs, et la dite république étant vassal de la S. P., c'est-à-dire dépendante, soumise et protégée (the Ottoman emperor and his successors being suzerains of the aforementioned republic, that is to say lords, princes and protectors, and the said republic being vassal of the S.P., that is to say dependent, subject and protected)", cited from Fujinami Nobuyoshi, Between Sovereignty and Suzerainty: History of the Ottoman Privileged Provinces, in A World History of Suzerainty, pp 44-5.
} 
and appoint themselves but in whose nomination the Porte would have a defined right. ${ }^{109}$ Although the Ottoman Empire had no place in this treaty, the concept of suzerainty born in the case of Ionia became more definite during the Greek War of independence. ${ }^{110}$ Through the Treaty of Adrianople of 1829 between the Ottomans and Russia, the Ottoman Empire not only acknowledged the status of Greece as under the Ottoman suzerainty as stipulated in the Treaty of London but also defined its relations to Wallachia and Moldavia as suzerain rights. According to Article V of the treaty, Moldavia and Wallachia were under the suzerainty of the Ottoman Empire and were also guaranteed protection by the Russian Empire. ${ }^{111}$ In fact, Article V only provided the Ottoman Empire with a nominal right because the people of these principalities were under Russian military occupation. Through the above discussion, it can be seen that although the Treaty of Constantinople of 1800 and the Treaty of Adrianople of 1829 explicitly confirmed the Ottoman's suzerainty over Ionia, Wallachia and Moldavia, Istanbul in fact had no actual external sovereignty over the above principalities as they were either under Russian occupation or under its protection. Even in the Treaty of London of 1827, in which the Ottoman Empire's privileges in regard to Greece were clear, it was still uncertain whether these three Powers undertook the obligation of dealing with Greece through the Ottoman Empire.

But things did not stop there. In fact, the distinction between sovereignty and suzerainty was not clear within the Ottoman Empire seeing that the Western diplomats did not always regard them as two clearly different terms. ${ }^{112}$ Not all the autonomous regions were placed under Ottoman suzerainty. For example, Egypt was an autonomous area but remained under the sovereignty of the Ottoman Empire. According to Article IV of the Treaty of London of 1840, the Sultan's sovereignty over Mehmet Ali, the ruler of Egypt, was safeguarded by Great Britain, Austria, Prussia and Russia. ${ }^{113}$ However, at that time, the Ottoman Empire not only lost its control over Egypt, but Egypt in turn posed a threat to the Ottoman Empire during the Second Egyptian-Ottoman War. In this

\footnotetext{
${ }^{109}$ The French version of the treaty of London, see https://mjp.univ-perp.fr/constit/gr1827t.htm.

${ }^{110}$ Fujinami Nobuyoshi, p 46.

${ }^{111}$ The French version of Article V of the Treaty of Adrianople, see Fujinami Nobuyoshi, p 47.

${ }^{112}$ For example, a separate act attached to the Treaty of Adrianople declared that the Ottomans' "droits de Souverainet" over the Principalities would not be damaged. See Aristarchi Bey, 1873-88: Législation ottomane, ou recueil des lois, règlements, ordonnances, traités, capitulations et autres documents officiels de l'Empire ottoman. vol. 2. Constantinople: Imprimerie Frères Nicolaïdes; Bureau du journal Thraky, pp. 145-6.

${ }^{113}$ James T. Shotwell, A Short History of the Question of Constantinople and the Straits, Greenwich, New York, 1922, p 507. Also see Fujinami Nobuyoshi, p 49.
} 
sense, the Ottomans' sovereignty was internationally preserved by the Great Powers, but the Ottomans had already lost their sovereign rights over Egypt.

It can be seen from this discussion that the term 'suzerainty' was a concept by which Westerners could intervene and explain the dissolution of the Ottoman Empire. The Great Powers utilised this concept to maintain a balance of power at the expense of the Ottoman Empire but without directly bringing the Empire into dissolution. Due to this diplomatic concern, the practice of suzerainty in the Ottoman Empire was inconsistent and its differences with sovereignty were also deliberately blurred by the Westerners.

Because suzerainty obscured and complicated the relationships between empires and their peripheries not under their direct control, it provided considerable ambiguity for colonists in the rest of the world to differently define the position of frontier regions from case to case. For example, the Convention of Pretoria of 1881 which was concluded between the Transvaal Boers and Great Britain stipulated that the inhabitants of the Transvaal territory should enjoy complete self-government under the suzerainty of Great Britain. ${ }^{114}$ As Lord Kimberly argued, 'The term suzerainty has been chosen as most conveniently describing superiority over a state possessing independent rights of government, subject to reservations with reference to certain specified matters'. ${ }^{115} \mathrm{But}$ at this stage, what suzerainty referred to remained unclear. It was the 1844 London Convention that further clarified the relationships between Britain and the Transvaal. Although this convention did not use the expression of suzerainty in its provisions, it allowed Transvaal greater freedom to conduct its foreign affairs; however, any foreign agreements concluded by Transvaal were subject to the approval of Great Britain. ${ }^{116}$ In this sense, unlike the theories which are generally accepted by theorists of international law, the external sovereignty of Transvaal was not entirely absorbed by Great Britain.

Another slightly different exception than Transvaal was that of British India. Although the Act of 1858 which established direct rule of Great Britain over India did not mention the term suzerainty, the Interpretation Act of 1889 expressly indicated that the expression 'India' should mean British India together with any territories of any native

\footnotetext{
${ }^{114} \mathrm{https}$ ://www.sahistory.org.za/archive/convention-pretoria-convention-settlement-transvaal-territory-3-august1881.

${ }^{115}$ J. Westlake, The Transvaal War: A Lecture Delivered in the University of Cambridge, 9th November 1899, p. 31. Recite from Amy Kellam, Suzerainty and the 1914 Simla Agreement, Jus Gentium: Journal of International Legal History, Vol. 3, 2018, p 157.

${ }^{116}$ Ibid.
} 
prince or chief under the suzerainty of Her Majesty exercised through the GovernorGeneral of India. ${ }^{117}$ According to Kelke, the relationships of such Indian States to Great Britain depend on numerous treaties. Generally, the British rights included:

(a) restraining their right of making peace and war and sending embassies;

(b) limiting the amount of their armies;

(c) compelling submission to the presence of a British resident;

(d) regulating residence of Europeans among them;

(e) deposing in case of internal misgovernment; and

(f) in some cases, paying tribute. ${ }^{118}$

This differs from the example of Transvaal, which retained internal autonomy in relations under their suzerain powers, because the restrictions imposed on British India to some extent resulted in the loss of internal autonomy for Indian princes, despite the fact that Britain still described its relation with the Indian princes as suzerainty. As Courtenay Ilbert pointed out in the India case, 'suzerainty is a term which is perhaps incapable of precise definition but which is usefully employed to indicate the political authority exercised by one State over another and approximating more or less closely to complete sovereignty'. ${ }^{119}$

In conclusion, theorists generally viewed the concept of suzerainty as built on the assumption that the sovereignty of the vassal State can be divided into external and internal sovereignty, while the external sovereignty of the vassal State is absorbed by the suzerain State. Because of the lack of external sovereignty, the vassal State has no position of its own in international society and constitutes a portion of the suzerain State. However, this definition cannot accurately reflect the practices of States during the nineteenth and the twentieth century. In the case of the Ottoman Empire, its external sovereignty over its Christian principalities had already become nominal regardless of the many treaties which confirmed it. On the contrary, even though the Ottoman's control over Egypt had been lost, its sovereignty over Egypt was still recognised by the Great Powers. This shows that Westerners were not only inconsistent in the practice of suzerainty within the Ottoman Empire, they also often blurred the distinction between

\footnotetext{
${ }^{117}$ https://www.legislation.gov.uk/ukpga/1889/63/pdfs/ukpga_18890063_en.pdf, Article 18 (5) of the Interpretation Act of 1889

${ }^{118}$ W. Kelke, supra n.104, p 225.

${ }^{119}$ Wallwyn Shepheard, Suzerainty, Journal of the Society of Comparative Legislation, Vol. 1, No. 3, 1899, p 437. Also see Courtenay Ilbert, the Government of India, Oxford at the Clarendon Press, 1922.
} 
suzerainty and sovereignty in describing the relation between Istanbul and its principalities. Similarly, the practice of suzerainty in South Africa and India was also not fully in accordance with its theorical definition in international law. Therefore, due to the discrepancy between its legal definition and practice, the content of suzerainty is ambiguous as it always differs from case to case. In the next section, a brief review is given to examine whether the Qing Government possessed sovereignty or suzerainty before its collapse in 1911 .

4.3.3 The Dispute on the Status of Tibet between China and Britain - Sovereignty or Suzerainty

Back to the case of Tibet, by carrying out 'Twenty-Nine Regulations for Better Government in Tibet', the amban established his supreme authority in Tibet in the late of the eighteenth century. ${ }^{120}$ After that, the Qing Government established a comprehensive authority which was likely to amount to sovereignty in the Western discourse. However, as British involvement in Tibet increased, the Qing's authority over Tibet declined throughout the second half of the nineteenth century. But during this period, the British still concluded a series of Tibet-related treaties with the Qing Government rather than the Tibetans. Instead of recognising Tibet as an independent State, Britain implied through these treaties that Tibet was a part of the Qing Empire and the British could only deal with the Tibetans through the Qing Government. From this perspective, if Tibet had any kind of external sovereignty, it should have been placed in the hands of the Qing Government. However, the British Expedition to Lhasa in 1903 and the conclusion of the 1904 Lhasa Convention significantly challenged the Qing's authority in Tibet. Although the Qing's authority in Tibet did have a tendency to suzerainty during this period, the presence of the amban allowed the Qing Government to basically maintain control of Tibet, thus avoiding situations like the Ottoman Empire completely losing control of its principalities. Meanwhile, the Sino-British Convention of 1906 to some extent indirectly recognised that the Qing Government possessed the right to administer the internal affairs of Tibet. In this sense, caution should be exercised in the use of the term 'suzerainty' to describe Sino-Tibetan relations during this period. At the same time, the observation of whether the Qing possessed sovereignty or suzerainty over Tibet should not stop at the conclusion of the Anglo-Russian

\footnotetext{
${ }^{120}$ See Section 2.3.3 in Chapter 2.
} 
Convention of 1907. In view of the fact that the Qing Government had carried out a series of reforms aimed at restoring its authority in Tibet since the British Expedition of Tibet in 1903 to the collapse of the Qing Dynasty in 1911, this question should be examined in a broader time frame. For this purpose, the next chapter will further discuss whether or not the Qing's authority over Tibet was suzerainty in the context of the Qing's New Deal in Tibet.

In conclusion, the Anglo-Russian Convention of 1907 explicitly demonstrated that the Qing Government was responsible for the external sovereignty of Tibet on the one hand. On the other hand, the term of suzerainty produced significant ambiguity on the status of Tibet. As the Convention of 1907 might not accurately reflect Sino-Tibetan relations from the late eighteenth century to the early twentieth century, the observation on whether the Qing Government had sovereignty or suzerainty over Tibet should be made in a broader time frame.

\section{Conclusion}

In the early twentieth century, considering the strong opposition from the Tibetans and the weak Chinese authority in Tibet, the British no longer expected that the Qing Government could fulfil its treaty obligations. At the same time, the expansion of Russian influence in Tibet finally led the British to launch a military expedition to Tibet in 1903. As a consequence of the expedition, the Lhasa Convention of 1904 was concluded between the British and the Tibetans without the adherence of the Qing Government. This convention was the first legal instrument that the British Government concluded with the Tibetan government rather than with the Qing Government, and it brought great ambiguities to the status of Tibet in the early twentieth century. Through an analysis of the British practice of making treaties with local kings and chieftains in Africa and America since the eighteenth century, the conclusion of the Lhasa Convention itself could not prove that Britain implicitly recognised Tibet as an independent sovereign State. On the contrary, the attitude of London after learning the content of the convention properly indicated that Tibet was not independent in the eyes of the Secretary of State for India and members of parliament. More importantly, the Qing Government did not retroactively recognise the Lhasa Convention, which made its validity questionable. In addition, since a protectorate should be a fully sovereign 
State before the conclusion of a treaty of protectorate, it might be difficult to say that Tibet had become a British protectorate by virtue of the Lhasa Convention; instead, the agreement of 1904 successfully brought Tibet into the British sphere of influence. In fact, it can be concluded from an examination of the statements put forward by Younghusband during the negotiation and the texts of the 1904 Convention that the purpose of the British was to bring Tibet into their sphere of influence to prevent Russia from getting involved.

Two years later, another Sino-British Convention relating to Tibet was concluded in Peking. By excluding China from the phrase of 'foreign Power' as stipulated in Article IX of the Lhasa Convention, the convention implicitly allowed China to intervene in the internal affairs of Tibet. From this perspective, the Sino-British Convention of 1906 was not in line with the Chinese suzerainty over Tibet which was insisted upon by the British. With the attachment of the Lhasa Convention of 1904 to this Sino-British Convention as an annex, the Qing Government in fact gave its retroactive recognition of the Lhasa Convention, which transformed it from a questionable legal instrument into a valid treaty in international law.

In 1907, Britain and Russia in recognition of the situation in Europe decided to calm down their confrontations in Asia and concluded an Anglo-Russian Convention relating to Tibet. This convention explicitly demonstrated that, on the one hand, the external sovereignty of Tibet was in the hands of the Qing Government; on the other hand, the term of suzerainty stipulated in the treaty also produced significant ambiguities in SinoTibetan relations. There was also a great discrepancy between the theoretical perception of suzerainty and State practices during the nineteenth century. As a concept first used to describe the relations between the Ottoman Empire and its non-Muslim principalities by Western Powers, its application within the Ottoman Empire was inconsistent because there was no clear distinction between sovereignty and suzerainty in the practices of Western Powers at that time. Similarly, for the rest of the world, the content of suzerainty was ambiguous because it differed from case to case. With regard to SinoTibetan relations, although the Qing Government had established authority which was likely to amount to sovereignty in the Western sense in the late eighteenth century, its influence in Tibet declined throughout the second half of the nineteenth century because of the expansion of British influence in this region. The British expedition to Tibet in 1903 and the conclusion of the Lhasa Convention of 1904 significantly damaged the 
Qing's authority in Tibet, but the presence of the amban to some extent maintained the Qing's sovereignty over Tibet. Given that the Qing Government implemented a New Deal aimed at restoring its authority in Tibet after the British expedition, it is necessary to assess to what extent these reforms affected Sino-Tibetan relations. The next chapter will continue to observe whether the Qing Government had sovereignty or suzerainty over Tibet by bringing this question into a border orbit of the New Deal on Tibet in the late Qing Dynasty. 


\section{Chapter 5 The Position of Tibet During the Early Period of the Republic of China}

\section{Introduction}

By concluding the Anglo-Russian Convention of 1907, Britain and Russia defined the Qing's rights in Tibet as suzerainty, but the Qing Government had refused to accept this formula on any diplomatic occasion. Considering that its authority over Tibet had been declining since the second half of the nineteenth century, it is understandable that the Western Powers challenged the Qing's claim of sovereignty over Tibet. With regard to the meaning of suzerainty in Sino-Tibetan relations, according to the British explanation, it referred to the internal autonomy of Tibet without Chinese interference. ${ }^{1}$ As mentioned in the previous chapter, to examine whether the Qing's authority in Tibet was suzerainty or sovereignty, it should consider Sino-Tibetan relations throughout the Qing Dynasty as a whole rather than solely focus on the second half of the nineteenth century. In fact, after Britain's invasion of Tibet in 1903, the Qing Government carried out a series of reforms known as the 'New Policy' to restore its influence in Tibet. In a sense, if one was regarding the development of the Qing's rule in Tibet as a dynamic process, then the Qing's new policy during the first decade of the twentieth century constitutes an inseparable component of this process. In the meantime, it also provides a particular perspective to assess whether the Qing's rights in Tibet was suzerainty or sovereignty before the collapse of the Qing Dynasty in 1911. To this end, this chapter first examines whether the Tibetans could exercise internal autonomy in the context of the Qing's new policy before 1911. At the same time, it also focuses on the peaceful interactions between the Tibetans and the Chinese during the Period of the Chinese Republic. The Chinese Revolution of 1911 not only ended the reign of the Qing Dynasty but also ruined the achievements of the Qing's new policy in Tibet. By taking advantage of the chaotic situation of China proper, the Tibetans expelled the Qing officials and soldiers from Tibet, and the $13^{\text {th }}$ Dalai Lama returned to Lhasa from India and began to exclude the Chinese influence from Tibet. Therefore, from the exiled Tibetan 
Government's perspective, Tibet had formally gained its independence in the 1911 Revolution. In order to discuss the development of Tibet's status against the background of the rupture of Sino-Tibetan connections, the chapter also explores the efforts made by the Tibetans to achieve Tibet's independence as well as the position of the Chinese Republican Government in the face of the Tibetan independence movement. Compared with the next chapter, which aims to explain the legal nature of the Dalai Lama's regime in the context of the Sino-Tibetan armed conflicts, this chapter investigates the peaceful interactions between the Republican Government and the Dalai Lama's regime at the beginning of the Republican period. This mainly involves the activities of the Tibetan government in its strive for independence and the conclusion of the Simla Convention, in which Great Britain, China, and Tibet aimed to settle the status of Tibet in 1914. To this end, with the exception of the discussion on the Qing's New Policy in Tibet, the research period is limited from the Chinese Revolution in 1911 to the conclusion of the Simla Convention in 1914.

The chapter consists of three sections. In order to clarify the status of Tibet during the late Qing Dynasty, it is necessary to determine whether the Qing Government possessed suzerainty or sovereignty over Tibet. If the Qing only had suzerain rights over Tibet, then the latter should be considered as a vassal State in relation to the Qing. Otherwise, it should be regarded as a normal part of the Chinese territory under the sovereignty of the Qing. Therefore, the first section explores the influence of the Qing's new policy on Sino-Tibetan relations before the 1911 Revolution. The second section discusses the legal nature of the Tibetan government's pursuit for independence and their effects in changing Tibet's status under international law. This section includes an examination of the legal effects of the Dalai Lama's proclamation in 1913, which was often cited as Tibet's declaration of independence, and a discussion on the validity of the 1913 Mongol-Tibetan Treaty under international law. The third section explains the influence of the Simla Convention on Tibet's status. It first introduces the divergent positions between China, Britain, and Tibet on Sino-Tibetan relations during the Simla Conference. It subsequently reveals how the Simla Convention complicated the status of Tibet by analysing its articles. In this chapter, the 1913 Treaty of friendship and alliance between Mongolia and Tibet, the proclamation issued by the $13^{\text {th }}$ Dalai Lama on 14 February 1913, and the draft of the Simla Convention between Great Britain, China, and Tibet in 1914 serve as primary sources to demonstrate the efforts of the Dalai Lama's regime to rid Tibet of China's influence and its legal effects. In the 
meantime, to understand the different positions of Britain, China, and Tibet on the latter's status, materials from the aforementioned parties are selected as secondary sources. These include the archives of the Chinese Republican Government in response to the situation in Tibet after the 1911 Revolution; the Chinese record regarding the process of the Simla Conference and its results; the British materials from the Foreign Office and the India Office which reflect the motivation of the British to host the Simla Conference and the goals they want to achieve. Furthermore, these documents are helpful in understanding the position of Tibet during the Conference. By comparing the positions of the three parties reflected in these materials, it is possible to identify their divergence on the status of Tibet and how they reached a compromise in the draft of the Simla Convention.

\subsection{The Qing Dynasty's New Policy in Tibet from 1903 to 1911}

After undergoing a series of crises such as the Boxer Rebellion and intervention from foreign Powers, ${ }^{2}$ the elites of the Qing Government realised it was necessary to carry out a nationwide reform to enhance national strength. It was in this context that the Qing Government had implemented many reform measures since 1901. Concerning Tibet, the British Expedition to Lhasa in 1903 triggered the Qing Government to restore its influence in Tibet. As early as 1903, many military, administrative, and economic measures had already been performed by the Qing officials to consolidate the Qing's authority in eastern Tibet adjacent to Szechuan Province. After the conclusion of the 1906 Anglo-Chinese Convention and 1907 Anglo-Russian Convention, the Qing Government appointed Chang Yin-tang (张荫棠) as High Commissioner to investigate the situation in Tibet and to take corresponding measures. This section aims to explore Qing's reform attempts in Tibet and to examine whether these measures followed the description of the suzerainty stipulated in the Anglo-Russian Convention of 1907.

\footnotetext{
${ }^{2}$ The Boxer Rebellion was an anti-foreign and anti-Christian uprising in China between 1899 and 1901, which tried to drive all foreigners from China. 'Boxers' was a name that foreigners gave to a Chinese secret society known as the Yihequan (义和拳). The Yihequan greatly opposed missionaries and foreigners destroyed churches, railroads and mines. In response to the violence and murder of foreign civilians, American, Austro-Hungarian, British, French, German, Italian, Japanese, and Russian troops was dispatched from the northern port of Tianjin to Beijing to suppress the uprising. Consequently, the Empress Dowager Cixi (慈禧) supported the Boxers and issued an imperial decree declaring war on the above foreign powers. The Qing army was defeated by the Eight Nation Alliance (八国联军), and after extensive discussions, a treaty was finally signed in September 1901, ending the hostilities and providing for reparations to be made to the foreign Powers.
} 


\subsubsection{The Situation in Eastern Tibet}

Kham is one of three traditional Tibetan regions, along with U-Tsang and Amdo, and is located between the eastern portion of Tibet and the western portion of Szechuan Province. Theoretically, Kham had been under the supervision of Szechuan Province since 1725, but the peoples of Kham had maintained their independence in the form of two dozen or more kingdoms and tribes. ${ }^{3}$ Local chieftains ruled their territories with hereditary titles bestowed by the Qing Government, and most of them worshipped the Dalai Lama and often contacted Kashag (the Tibetan local government). As the Qing authority only maintained a limited existence in Kham to support communication and transport of officials from Szechuan to Tibet, these local chieftains were able to rule with a large degree of independence from both the Qing Government and Kashag. ${ }^{4}$ It was the 1903 British invasion of Tibet that stimulated the Qing Government to restore its authority in Tibet; to achieve this, the very first step was to establish direct control over the kingdoms and tribes living in the Tibet-Szechuan border areas, which is Kham.

In 1903, the Grand Council (军机处) in Peking issued a proposal to open up wasteland by immigrating Chinese settlers from Szechuan to Kham and promote the Chinese military existence in Kham. ${ }^{5}$ In response to the proposal, Hsi-Liang (锡良), the Governor-General of Szechuan, began to carry out a policy of usurping the power of the local chieftains and appointing the Qing's officials to establish military-agricultural habitations in Kham. ${ }^{6}$ In the meantime, the Qing Government approved the advice proposed by the amban Youtai (有泰) that transferred assistant amban from Lhasa to Chamdo in the western part of Kham to facilitate Hsi-Liang's reforms along the TibetSzechuan border. ${ }^{7}$ The newly appointed associate amban Feng Ch'uan(凤全) arrived at Batang on the way to Chamdo and remained there to establish administrative control. Feng attempted to restrict the scale of monasteries, but under his leadership, an anti-

\footnotetext{
${ }^{3}$ Warren W. Smith, Tibetan Nation - A History of Tibetan Nationalism and Sino-Tibetan relations, Westview Press, 1996, p 168.

${ }^{4}$ Hugh E. Richardson, Tibet and its History, Second Edition, Boulder and London: Shambhala, 1984, pp. 28-68.

${ }^{5}$ The Grand Council was an important policy-making body of China during the Qing dynasty. It was established in 1733 by the Yongzheng Emperor. It was originally in charge of military affairs, but gradually attained a more important role in the government. In fact, the Grand Council was an informal policy making body in the inner court and its members held other concurrent posts in the Qing civil service. See Qing Shilu (清实录), vol. 58, July of the Twenty-ninth years of Guangxu Emperor, Zhonghua Shuju (中华书局), 1987, p 855.

${ }^{6}$ Tatiana Shaumian, Tibet-The Great Game and Tsarist Russia, Oxford University Press, 2000, p 142.

${ }^{7}$ Zhao Yuntian (赵云田), The Study on New Policies in Late Qing Dynasty(清末新政研究), Heilongjiang Education Press, 2014, p 235. With regard to amban, see 2.3.3 in chapter 2.
} 
Manchu uprising soon broke out in Batang in 1905, and many local lamas participated in the rebellion. ${ }^{8}$ After Feng was killed in Batang, the rebellion then spread to neighbouring regions along the Szechuan-Tibetan border. In response to Tibetan's resistance in Kham, Szechuan authority immediately sent a punitive expedition, which consisted of 2000 men led by Ma Wei-ch'i (马维骐) and Chao Erh-feng (赵尔丰), to restore Chinese control. In June of 1905, they captured Batang and executed local Tibetan chieftains and lamas who participated in the uprising. After Ma returned to Szechuan, Chao was appointed as High Commissioner of the Szechuan-Yunnan Frontier Affairs to deal with all questions relating to settlement and defence in Kham. ${ }^{9}$ In Batang, Chao announced that since the local chieftains had been beheaded, both the Chinese and the tribesmen of Batang were subjects of the emperor, and they must submit to the jurisdiction of Chinese officials. ${ }^{10}$ Subsequently, a series of reform measures were taken to carry out Chao's commitment.

In the political field, the office of the local chieftain was permanently abolished and was replaced by Chinese officials assigned by the Qing Government. The Tibetans of Kham were obliged to pay tax to Chinese officials and were forbidden to serve the local monastery; lamas were not allowed to interfere in any way with the administration of the district. In the judicial field, all lawsuits, regardless of whether the parties were Chinese or Tibetan, would be decided by the Chinese local authorities. In the economic field, Chao encouraged the Chinese population in the neighbouring provinces to settle in Kham and to reclaim wastelands. He promised to provide them with the best lands for cultivation and offered seeds and agricultural tools to them. ${ }^{11}$ In the religious field, the Tibetan monasteries were allowed to exist, but each monastery was limited to a maximum of 300 monks; the Chinese officials constructed Chinese Confucius temples, but lamas were not permitted to reside in them. In the educational field, Chinese schools were established in Kham, and all boys from the age of 5 or 6 were enforced to attend these schools. ${ }^{12}$

\footnotetext{
${ }^{8}$ Feng tried to limit the power of monasteries by prohibiting them from accepting recruits for a period of twenty years. Besides, brutal suppression of the Tibetan inhabitants, execution of lamas, eviction of local people from the most fertile land, and forcible conscription in the army also lead to the resentment against Feng. See Tatiana Shaumian, $\mathrm{p} 143$.

${ }^{9}$ Zhao Yuntian, p 239.

${ }^{10} \mathrm{IOR} / \mathrm{L} / \mathrm{PARL} / 2 / 334$, Enclosure in No. 159, Regulations for the Future Administration of Batang, Dispatch from the Acting Consul-General, Cheng-tu, to Sir. Jordan, dated $29^{\text {th }}$ December, 1906.

${ }^{11} \mathrm{IOR} / \mathrm{L} / \mathrm{PARL} / 2 / 334$, Enclosure in No. 182.

${ }^{12}$ Ibid.
} 
Through the repression of local chieftains and monastic influence, Chao Erh-feng successfully broke the spiritual and economic dominance of lamas along the SzechuanYun'nan-Tibetan border. At the same time, a set of governmental institutions in charge of civil and judicial affairs, tax, and education were established in Kham. The activities of the Qing Government in Kham reflected a strategic shift from maintaining its influence through conferring titles on local chieftains and patronizing Buddhism to gradually incorporating Kham into the Qing's direct administration.

\subsubsection{Chang Yin-tang's New Policy in Lhasa}

The British invasion of Tibet in 1903 stimulated the Qing government to restore its authority over Tibet. Taking advantage of the Dalai Lama's escape to Mongolia and the conclusion of the Anglo-Chinese Convention of 1906, ${ }^{13}$ the Qing Government appointed Chang Yin-tang, who participated in the negotiation of the Convention of 1906, as High Commissioner to reform Tibetan administration. ${ }^{14}$ Chang arrived in Tibet in the autumn of 1906 and worked to recover the Qing's control over Tibetan administration.

To eliminate obstacles to reform, Chang first sent a telegram to the Qing Government to dismiss the amban You-tai for corruption and incompetence in his failing to prevent the British army from invading Tibet. ${ }^{15}$ In response to Chang's request, the Qing Government imprisoned You-tai and exiled him to the garrison in He Bei (河北). Moreover, several Chinese officials in Tibet were also punished or degraded for the same reason. Concerning the Tibetan officials, a similar action was taken against those Tibetan officials who took part in the negotiations with the British in $1904 .{ }^{16}$ On these grounds, the British believed Chang's action intended to sweep away all pro-British officials. Therefore, they protested this to the Qing Government. ${ }^{17}$ In a written reply

\footnotetext{
${ }^{13}$ The $13^{\text {th }}$ Dalai Lama fled to Mongolia before the British army entered Lhasa in 1904 and then moved to Amdo (Qinghai Province) to wait for instruction from the Qing court. Therefore, the absence of the Dalai Lama in Lhasa provided the amban an opportunity to expand his influence and to take in charge of the administration of Tibet. In the meantime, Article II of the Convention prohibited Great Britain from interfering in the administration of Tibet, and the Qing also undertook not to permit any other foreign State to interfere the administration of Tibet. This article legally ensured that the Qing Dynasty's activities in Tibet would not be opposed by Britain.

${ }^{14}$ Charles Bell, Tibet: Past and Present, Oxford University Press, 1968, p 88.

${ }^{15}$ Zhao Yuntian, p 258.

${ }^{16}$ Tatiana Shaumian, p 145.

${ }^{17} \mathrm{IOR} / \mathrm{L} / \mathrm{PARL} / 2 / 334$, No. 144.
} 
from the $W a i-W u-B u$, the Chinese official insisted that the former amban and the Tibetan officials were punished for corruption and they simultaneously promised that the relations between British and Tibetan officials would be maintained through the Chinese officials appointed by Chang. ${ }^{18}$ The punishment of the incompetent officials, no matter whether they were Chinese or Tibetan, demonstrated that the Qing Government had substantially utilised its power of appointing and degrading local officials which stipulated in the Twenty-Nine Regulations for the Better Government in Tibet of $1792 .{ }^{19}$ To some extent, this confirmed that the Qing officials once again played a dominant role in Tibet's internal administration, albeit under the pressure from the British. According to Alexandrowicz, in the relations between vassal State and suzerain State, the former is deprived of external sovereignty while it retains internal sovereignty, which the latter is under a duty to respect. ${ }^{20}$ As discussed previously, the internal administration of Tibet was dominated by the Qing officials rather than the officials of the Kashag. Therefore, suzerainty may not be an appropriate term to define SinoTibetan relations during this period. On the contrary, under the infiltration of the Qing Government into Tibet's external and internal affairs, the Qing's authority over Tibet was more in line with the definition of sovereignty.

By taking advantage of the Dalai Lama's absence in Tibet, Chang Yin-tang and his successor Lian $\mathrm{Yu}$ (联豫) carried out a series of reforms aimed at strengthening Chinese control over Tibet. To promote the administrative system, Chang submitted a proposal that set up nine new offices to manage the military, trade, tax, agriculture, communication, and mining. However, his measures were resisted by both conservatives from the Qing Government and the Tibetan aristocrats due to a lack of money. ${ }^{21}$ After his nine-month tenure, Chang was replaced by Lian Yu, who was appointed as the new amban, to take over the administration of Tibet. Although Lian was hostile to Chang, he had, to a large extent, followed the reform policies of his predecessor and put most of them into effect. In the field of the administrative system, Lian abolished the grain commissaries that provided military supplies. In the meantime, the grain commissaries' function of adjudicating Chinese lawsuits was transferred to

\footnotetext{
${ }^{18}$ IOR/L/PARL/2/334, No. 149.

${ }^{19}$ See Section 2.3.3 in the Chapter 2.

${ }^{20}$ Alexandrowicz Alexander, The Legal Position of Tibet, American Journal of International Law, Volume 50, Issue 2, 1956, p 266.

${ }^{21}$ Zhao Yuntian, Discussion on Tibet's New Policy in the Late Qing Dynasty (清末西藏新政述论), Modern Chinese History Studies, vol.5, 2002, pp 108-09.
} 
officials with the rank of Sub-Prefects in Chamdo, Lali, and further Tibet. ${ }^{22}$ In the economic field, Lian ordered the minting of new silver coins with the title of the Qing Dynasty to highlight China's economic sovereignty at a time when the rupee was widely used in Tibet. ${ }^{23}$ In 1908 and 1909, three trading marts were opened in Gyantse, Yatung, and Gartok to trade with India, and Chinese customs administration was introduced in the above places. ${ }^{24}$ With regard to public order, Lian established a police station of approximately 160 men in Lhasa in 1909, and planned to open two branches in Gyantse and Yatung after training an adequate number of police officers. ${ }^{25}$ In the field of culture, specialised schools were opened to teach the Tibetan and Chinese languages, and a printing office was subsequently added. ${ }^{26}$ To strengthen the defence of Tibet, a modern army of 6000 men, of whom three-fifths were Chinese and two-fifths Tibetans, was trained for service in Tibet. Besides, Lian also drafted fourteen cadets from the Szechuan Military college to Tibet to found a military training college in Lhasa. ${ }^{27}$

From Chang and Lian's measures, the Qing's New Policy clearly aimed to gradually convert Tibet into a Chinese province. Although Chang and Lian only partly fulfilled these measures, their achievements were considered 'bright spots' compared with their predecessors. ${ }^{28}$ Given that the Qing Government was too weak to fully support the new policy in Tibet, these measures were not enough to turn Tibet into a Chinese province under the direct control of the Qing Government. Instead, under the appearance of modernisation, the Qing's control over Tibet was restored and even exceeded the level of control in the late eighteenth century. In other words, Tibet was generally under a hybrid rule in which its internal affairs were led by the amban and jointly managed by the Chinese and Tibetan officials. In short, the Qing's new policy made its rule in Tibet more like a kind of sovereignty rather than suzerainty.

\footnotetext{
${ }^{22}$ FO/881/9231, Enclosure in No. 57, Extract from the "Peking Gazette" of July 18, 1907.

${ }^{23}$ Wu Fengpei (吴丰培), Lian Yu’s Memorials in Tibet (联豫驻藏奏稿), Tibet people's Publishing House (西藏人 民出版社), 1979, pp 111-12.

${ }^{24}$ Zhao Yuntian, Discussion on Tibet's New Policy in the Late Qing Dynasty, pp 116-17; Tatiana Shaumian, TibetThe Great Game and Tsarist Russia, p 146.

${ }^{25}$ Zhao Yuntian, The Study on New Policies in Late Qing Dynasty, pp 278-9.

${ }^{26} \mathrm{IOR} / \mathrm{L} / \mathrm{PARL} / 2 / 334$, Enclosure in No. 247, Memorial from Lian Yu, the Imperial Resident, on the establishment of a printing office and of a military college in Tibet, $2^{\text {nd }}$ June, 1908.

${ }^{27}$ IOR/L/PARL/2/334, Enclosure in No. 205, Summary of a Memorial by the Board of Finance respecting Tibet, approved by Imperial Rescript of $20^{\text {th }}$ June, 1907; Enclosure in No. 247, Memorial from Lian Yu, the Imperial Resident, on the establishment of a printing office and of a military college in Tibet, $2^{\text {nd }}$ June, 1908.

${ }^{28}$ G. Clark, Tibet, China and Great Britain, Peking, 1924, p. 22, recite from Tatiana Shaumian, p 145.
} 


\subsubsection{The $13^{\text {th }}$ Dalai Lama in Peking}

When Younghusband's mission approached Lhasa in 1904, the $13^{\text {th }}$ Dalai Lama first fled to Mongolia and then stayed in Qinghai Province waiting for the opportunity to return to Tibet. In order to ensure the progress of the ongoing Sino-British negotiations for the Sino-British Convention of 1906, the Qing Government declined the Dalai Lama's request to return to Tibet from Qinghai for fear that he might become an obstacle in the negotiations. ${ }^{29}$ When the negotiations between China and Britain had been almost settled, the emperor granted the Dalai Lama to come to Peking for an audience in July of $1908 .^{30}$

When the Dalai Lama arrived in Peking on 28 September 1908, how to receive this Tibetan political and religious leader became a problem for the Qing Government because it reflected the Qing's attitude towards the Sino-Tibetan relations. Instead of letting the $W a i-W u-B u$ deal with this issue, the Board of Dependencies (理藩院) and the Imperial Household Department (内务府) were responsible for arranging the Dalai Lama's activities in Peking. ${ }^{31}$ According to a memorial of the Board of Dependencies to the emperor, the Dalai Lama needed to respectfully greet the emperor and kowtow to thank him for the gifts during his audience. ${ }^{32}$ Additionally, a low couch had to be prepared beside the emperor's throne on which the Dalai Lama may sit. ${ }^{33}$ It can be inferred that the Qing Government treated the Dalai Lama in the manner of treating a subordinate rather than a head of a sovereign State. In fact, to manifest the superiority of the Qing, the foreign envoys were also requested to kowtow in front of the emperor in the eighteenth century, and the States represented by these foreign envoys are

\footnotetext{
${ }^{29}$ IOR/L/PARL/2/334, No. 109; No. 115; No. 126.

${ }^{30} \mathrm{IOR} / \mathrm{L} / \mathrm{PARL} / 2 / 334$, Enclosure in No. 249, Extract from the "Peking Gazette" of $19^{\text {th }}$ July, 1908 - Imperial Decree.

${ }^{31}$ The Board of Dependencies was an agency in the Qing Government which supervised the Qing Empire's frontier Inner Asia regions such as its Mongolian dependencies and oversaw the appointments of Ambans in Tibet; The Imperial Household Department was to manage the internal affairs of the Qing imperial family, it was also in charge of the ceremonial and spiritual activities of the Qing imperial household and it also often played an important role in Qing relations with Tibet and Mongolia.

${ }^{32}$ Kowtow is the act of deep respect shown by kneeling and bowing so low as to have one's head touching the ground. In East Asian culture, the kowtow is the highest sign of reverence. It was widely used to show reverence for one's elders, superiors, and especially the Emperor.

${ }^{33}$ IOR/L/PARL/2/334, Enclosure in No. 258, Rules for the reception of the Dalai Lama sent form the Grand Council to the Board of Dependencies, the Board of Interior, and the comptrollers of the Imperial Household, $30^{\text {th }}$ September, 1908.
} 
obviously sovereign States. ${ }^{34}$ But one shall notice that the Western international law had not been introduced into China at that time, and the notion of reciprocal equality was incompatible with the tribute system which emphasised the supremacy of the emperor. Consequently, foreign envoys were regarded as a tribute mission. When it came to the early twentieth century, things were quietly different as the Qing Government had become familiar with international law and gained experience in dealing with other sovereign States on an equal basis. The traditional ceremonies and rituals, such as kowtow, were no longer used in communication with foreign States. For this reason, if the Qing Government had regarded Tibet as a sovereign State, it would not have applied the traditional rituals to the leader of Tibet.

During the Dalai Lama's stay, he received considerable attention from the public, including many foreign legations in Peking. As the Wai-Wu-Bu requested, members of foreign legations could visit the Dalai Lama accompanied by two Chinese officials in attendance. ${ }^{35}$ The British Minister John Jordan visited the Dalai Lama in Yellow Temple, and the visit was received by both Chang Yin-tang and Da Shou, who was delegated by the emperor to attend to the Dalai Lama. ${ }^{36}$ Similarly, the ministers of Russia, the United States, and France also received the audience in the same manner. According to Article II of Anglo-Russian Convention of 1907, Britain and Russia engaged not to enter into negotiations with Tibet except through the intermediary of the Chinese Government. Therefore, the attendance of the Chinese officials during such occasions was not only in accordance with Article II but also manifested the Qing's external sovereignty over Tibet.

The Dalai Lama had stayed in Peking for one month to visit the young Emperor Guangxu (光绪) and the Empress Dowager Cixi (慈禧), who was the actual ruler of the Qing. Before the Dalai Lama returned to Tibet, the Empress issued an imperial decree to him stating that he must obey the ordinance of the Qing Government and shall follow the established law, which he could only report to the emperor through the amban. ${ }^{37}$

\footnotetext{
${ }^{34}$ For example, when the first British diplomatic mission to China in 1793, George Macartney, the British envoy, was repeatedly urged to perform the kowtow during his audience with Qianlong emperor. See Peyrefitte, Alain, the Immobile Empire, Knopf Doubleday Publishing Group, 2013, pp 102-3.

${ }^{35} \mathrm{IOR} / \mathrm{L} / \mathrm{PARL} / 2 / 334$, Enclosure in No. 260, Note from the Wai-wu Pu to the Doyen of the Diplomatic Body, dated $8^{\text {th }}$ October, 1908.

${ }^{36} \mathrm{IOR} / \mathrm{L} / \mathrm{PARL} / 2 / 334$, Enclosure in No. 262, Memorandum, Dispatch from Sir. J. Jordan to Sir. Edward Grey, date Peking, 25 $5^{\text {th }}$ October, 1908.

${ }^{37}$ IOR/L/PARL/2/334, Enclosure in No. 264, Imperial Decree issued in the name of the Empress Dowager: 'When he (the Dalai Lama) has arrived in Tibet, he must carefully obey the laws and ordinances of the Sovereign State, and make known to all the good will of the Chinese Court; and he must admonish the Tibetans respectfully to observe
} 
Although the Dalai Lama sought to improve his position by proposing that he should report to the emperor directly, the Board of Dependencies refused to allow him to do so. Moreover, a new title of 'the Loyally Submissive Vicegerent, the Great, Good, Selfexistent Buddha of Heaven' was conferred on the Dalai Lama by the Empress Dowager to replace the old title of 'the Great, Good, Self-existent Buddha of Heaven'. ${ }^{38}$ In the eyes of John Jordan, the British Minister, it constituted 'the first unequivocal declaration on the part of China that she regarded Tibet as within its sovereignty, be it noted not, suzerainty'. ${ }^{39}$ This new title expressly indicated that the Qing rulers expected the Dalai Lama to sincerely submit to the Chinese authority and respectfully observe the orders of the Qing Government.

In conclusion, through Chao Erh-feng's radical reform in Kham, eastern Tibet had gradually been placed under the direct administration of the Qing Government. In central Tibet, Chang Yin-tang and Lian Yu also implemented a series of reforms to transform Tibet into a Chinese province. Although many of the reform plans had not been completed due to a lack of financial support, those that had been implemented, at least to some extent, restored the Qing Government's authority in Tibet's internal affairs and strengthened the Qing's sovereign claim over Tibet. As discussed in the previous chapter, the Qing's external sovereignty over Tibet was confirmed by the Sino-British Convention of 1906 and the Anglo-Russian Convention of 1907. Therefore, the question of whether Kashag could maintain Tibet's internal autonomy became a crucial factor in judging whether the Qing possessed suzerainty or sovereignty over Tibet. By carrying out a series of reforms, the Qing Government not only largely restored its ability to influence Tibet's internal administration but was also externally responsible for Tibet's affairs during the first decade of the twentieth century. From a broader perspective, the Qing formally established its authority over Tibet in the 1790s and consistently maintained this hybrid rule until the 1870s. From then to the British invasion of 1903, although the Qing's power in Tibet had declined, leading to the Tibetans not following the instructions of the amban, it did not mean that the amban

the laws and learn the ways of rectitude. In all matters he shall follow the established law of reporting to the Imperial Resident in Tibet for transmission by Memorials to us, as occasion arises; and he shall respectfully await our decision.' Extract from the 'Peking Gazette' of $3^{\text {rd }}$ November, 1908.

${ }^{38}$ Ibid.

${ }^{39}$ Maria Adele Carrai, Learning Western Techniques of Empire: Republican China and the New Legal Framework for Managing Tibet, Leiden Journal of International Law, vol. 30, Issue 4, p 813; E. Younghusband, India and Tibet, London: John Murray, Albemarle Street, 1910, pp 364-84. 
played no role in the Tibetan administration. ${ }^{40}$ On the other hand, the presence of the amban to a certain extent prevented the Qing's rule in Tibet from becoming nominal rights, although the amban only possessed limited power during this period. Since 1900, the Qing Government had once again restored its control of Tibet's internal affairs. Therefore, the Qing had broadly maintained its influence in Tibet's internal and external affairs from the 1790 s to the 1910 s if the Sino-Tibetan relations during the Qing Dynasty were regarded as a whole. In this sense, compared with the term 'suzerainty', sovereignty may be a more accurate term to define the relations between Tibet and the Qing Empire. The new policy launched by the Qing officials in the final stage of the Qing Dynasty can be considered as modern China's first State-building attempt in its frontier regions. However, the outbreak of the Xinhai Revolution of 1911 not only ended the rule of the Qing Dynasty but also ended the efforts to bring Tibet under the full sovereignty of China.

\subsection{The Xinhai Revolution and De Facto Independence of Tibet}

In early 1908, Chao Erh-feng was appointed as amban in Tibet. ${ }^{41}$ Due to his brutal suppression of the Tibetan rebellion in Kham, he earned himself the nickname "Butcher Chao". As such, his appointment was strongly opposed by the Tibetans for fear that he would bring a large army to Lhasa and abolish the Tibetan religion, as he did in Kham. When the Dalai Lama's request to the Qing Government to recall the appointment of Chao was declined, the Tibetans collected large numbers of soldiers to stop Chao's arrival. Unfortunately, this move was regarded as hostile by the Qing Government and prompted the latter to send troops to Lhasa. ${ }^{42}$ When the Chinese troops entered Lhasa in February 1910, the Dalai Lama fled again. Unlike his previous escape, this time his destination was India to seek British protection, and he stayed in India from 1910 to 1912.

\footnotetext{
${ }^{40}$ For example, in 1877, the amban Songyuan (松溎) led the search for the reincarnation of the $12^{\text {th }}$ Dalai Lama and asked the Qing Government to recognize the new $13^{\text {th }}$ Dalai Lama. In 1883, the amban Se Leng'e (色楞额) heard the case of lama robbing merchants' property in Ü-Tsang. See He Wenxuan (贺文宣), Memorabilia of the Qing's amban in Tibet (清朝驻藏大臣大事记), China Tibetology Press, 1993, p 364; 376.

${ }^{41}$ Instead of one amban and one assistant amban, as hitherto, there henceforth two ambans in Tibet, as the present one remained there. In IOR/L/PARL/2/334, No. 230, From Sir. J. Jordan to Sir. Edward Grey, dated Peking $6^{\text {th }}$ March, 1908.

${ }^{42}$ IOR/L/PARL/2/334, No. 292; No. 297. Enclosure 2 - Annexure 1.
} 
However, in 1911, the outbreak of the Revolution in China proper ended the rule of the Qing Dynasty, ${ }^{43}$ and Yuan Shih-kai was elected as the president of the new Republic of China. When the news of the Qing's collapse reached Lhasa, the Chinese troops stationed around the city mutinied in the name of the Revolution. The mutinying soldiers no longer obeyed the amban Lian's order and committed misconduct against the Tibetans. It was in such context that the Tibetan troops and civilians began to fight against the Chinese troops and forced them to surrender. ${ }^{44}$ Finally, the amban Lian and his troops were expelled from Tibet via India at the end of 1912. In January 1913, the Dalai Lama eventually returned to Lhasa. ${ }^{45}$ As a result, Tibet was no longer under Chinese influence, and Kashag began to pursue the recognition of Tibet's independence internationally. In the meantime, Mongolia was also experiencing a similar situation to Tibet. By 1911, when the Chinese Revolution broke out, unrest was widespread in Mongolia. In December, the Jebtsundamba established himself as Bogd Khan and declared the independence of Mongolia. ${ }^{46}$ For mutual recognition of their independence, Tibet and Mongolia signed a treaty in January of 1913, sealing their new independent status. ${ }^{47}$ Almost simultaneously, the Dalai Lama issued a proclamation to Tibetans defining the historical relations with the Chinese and clarifying the current situation. This proclamation was often cited as a declaration of Tibet's independence from China. In this section, the legal nature of the Mongolia-Tibetan Treaty and the Dalai Lama's proclamation are discussed to analyse the development of Tibet's status during the early period of the Republic of China.

\subsubsection{The Validity of the Mongolia-Tibetan Treaty}

After the Dalai Lama returned to Tibet from India, he had further consolidated his control over the administration of Tibet. At the same time, he began to seek external support for the independence of Tibet from Russia, Britain, and Mongolia. With the

\footnotetext{
${ }^{43}$ The 1911 Revolution was a revolution that overthrew China's last imperial dynasty - the Qing and established the Republic of China. The revolution was named Xinhai because it occurred in 1911, the year of the Xinhai (辛亥) stem-branch in the sexagenary cycle of the traditional Chinese calendar.

${ }^{44}$ Amar Singh, Himalayan Triangle - A historical survey of British India's relations with Tibet, Sikkim and Bhutan 1765-1950, published by the British Library, 1988, pp 59-60.

${ }^{45}$ Wendy Palace, the British Empire and Tibet 1900-1922, Routledge Curzon, 2005, pp 85-6.

${ }^{46}$ The Jebtsundamba Khutuktu is the spiritual heads of the Gelug lineage of Tibetan Buddhism in Mongolia. Tachibana Makoto, Somewhere between 'Independence' and 'Autonomy': Translating Concepts in Modern Mongolian in A World History of Suzerainty: A Modern History of East and West Asia and Translated Concepts, edited by Takashi Okamoto, Toyo Bunko, 2019, pp 177- 98.

${ }^{47}$ FO 535/16, No. 88, Enclosure 1, 1913.
} 
exception of Mongolia, Russia and Britain were not interested in recognising Tibet's independence. ${ }^{48}$ In January of 1913, Dorjiev, the representative of the Dalai Lama, signed a treaty of mutual recognition of independence with the Jebtsundamba of Mongolia in Urga.

The preamble of the Treaty stated that 'Mongolia and Tibet, having freed themselves from the dynasty of the Manchus and separated from China, have formed their independent States, and, having in view that both States from time immemorial have professed the same religion', have agreed to sign the Treaty to strengthen their mutual friendships. The first and second articles mutually recognised the independence of the other. Furthermore, the remaining articles stipulated that both States shall work together for the well-being of the Buddhist faith and shall afford each other assistance against external and internal dangers, etc. ${ }^{49}$

Some scholars regard this Treaty as an important legal document in the manifestation of the independent status of Tibet, but its validity is also questioned by others. ${ }^{50}$ The most controversial question concerns whether Tibet and Mongolia were eligible to conclude such a treaty from an international legal perspective. This eligibility refers to whether the entities in question were the subjects of international law during the early

\footnotetext{
${ }^{48}$ Nikolai S. Kuleshov, Russia's Tibet File - The unknown pages in the history of Tibet's independence, Library of Tibetan Works and Archives, 1996, p 109.

${ }^{49}$ IOR/L/PS/11/46, No. 723, 1913. The whole articles of the treaty were as follows: 'Article 1 . The ruler of Tibet, Dalai Lama, approves and recognizes the formation of an independent Mongol State, and the proclamation, in the year of the pig and the ninth day of the eleventh month, of Jebtsundamba Lama of the yellow faith as ruler of the country; Article 2. The ruler of the Mongol people, Jebtsundamba Lama, approves and recognizes the formation of an independent (Tibetan) State and the proclamation of the Dalai Lama as ruler of Tibet; Article 3. Both States will work by joint consideration for the well-being of the Buddhist faith; Article 4. Both States, Mongolia and Tibet, from now and for all time will afford each other assistance against external and internal dangers; Article 5. Each State within its own territory will afford assistance to the subjects of the other travelling officially or privately on affairs of religion or State; Article 6. Both States, Mongolia and Tibet, as formerly, will carry on a reciprocal trade in the products of their respective countries in wares, cattle, \&c., and will also open industrial establishments; Article 7. From now the granting of credit to anyone will be permitted only with the knowledge and sanction of official institutions. Without such sanction Government institutions will not consider claims. As regards contracts made previous to the conclusion of the present treaty, where serious loss is being incurred through the inability of the two parties to come to terms, such debts may be recovered by (Government) institutions, but in no case shall the debt concern "shabinars" or "khoshuns."; Article 8. Should it prove necessary to supplement the articles of the present treaty, the Mongolian and Thibetan Governments must appoint special delegates, who will conclude such agreements as the conditions of the time shall demand; Article 9. The present treaty shall come into force from the date of its signature.'

${ }^{50}$ For those who support this view, please see Michael. van Praag, A Legal Examination of the 1913 Mongolia-Tibet Treaty of Friendship and Alliance, in The Centennial of the Tibeto-Mongol Treaty: 1913-2013, Dharamshala: Amnye Machen Institute, 2013, pp 81-100. Sergius L. Kuzmin, The Treaty of 1913 between Mongolia and Tibet as Valid International Document, published in: 'The Centennial of the Tibeto-Mongol Treaty: 1913 - 2013' ,Lungta v. 17: E. Sperling, A. Tuvshintugs and Tashi Tsering eds., 2013, pp 53-9. Tsepon Wangchuck Shakabpa, One Hundred Thousand Moons - An Advanced Political History of Tibet Vol. 2, Brill, 2009, p 762. For those who oppose this view, see Alfred P. Rubin, The Position of Tibet in International Law, the China Quarterly, vol. 35, 1969, pp 110-54. Charles Bell, Tibet: Past and Present, Clarendon Press, 1924, p 151. Smith, Warren, Tibetan Nation: A History of Tibetan Nationalism and Sino-Tibetan Relations, Westview Press, p 186.
} 
twentieth century. ${ }^{51}$ According to Lauterpacht, only States are considered subjects of international law. ${ }^{52}$ Given that this view dominated in the early twentieth century, the validity of the Mongolia-Tibetan treaty depended on whether Tibet and Mongolia were sovereign States because the eligibility of making treaties only referred to sovereign States at that time.

With regard to the Mongolia-Tibetan treaty, in Articles I and II, the Dalai Lama and the Jebtsundamba Lama recognised that Tibet and Mongolia were independent States. It implies that neither Tibet nor Mongolia recognised the other as an existing State before the conclusion of the Treaty; otherwise, it would not be necessary to mention the issue of recognition. Likewise, if either Tibet or Mongolia were already recognised as a sovereign State by the international community, then there was no possibility of mutual recognition. Article I stated that the Dalai Lama recognised the formation of an independent Mongol State; this implied that the Tibetans did not recognise the independent Statehood of Mongolia until they signed the Treaty. Similarly, Article II recognising the formation of an independent Tibetan State by the Jebtsundamba Lama also revealed that Tibet was not an independent State in the eyes of the Mongols. Therefore, the legal effect of this mutual recognition is questionable. It depends on whether the declaratory or constitutive theory is adopted by the case.

According to Oppenheim, States, as the subject of international law, can be categorised into two types based on whether the recognition is required. Those States which are members of the Family of Nations are either original members because the law of nations evolved gradually between them through customs and treaties, or they are members who have been recognised by the body of members already in existence when they were born. For every entity that is not already, but wants to be, a member of the Family of Nations, recognition is therefore necessary. In this sense, a State is and becomes an international person through recognition only and exclusively. ${ }^{53}$ It can be seen from this constitutive view that the recognition of States only happens between an existing recognised State and a new State-like entity, but never between two or more new entities. On the contrary, the declaratory theory determines whether a new entity can become a subject of international law on the entity's assertion of its sovereignty within the territory it exclusively controls. It holds that recognition is irrelevant because

\footnotetext{
${ }^{51}$ Michael. van Praag, A Legal Examination of the 1913 Mongolia-Tibet Treaty of Friendship and Alliance, p 113.

${ }^{52}$ Hersch Lauterpacht, the collected papers, vol 1, Cambridge University Press, 1970, p. 489.

${ }^{53}$ L. Oppenheim, International Law, vol. 1, London: Longmans, Greens and Co., 1905, p 109. 
States have no discretion in determining whether an entity constitutes a State. ${ }^{54}$ Under the declaratory theory, it is possible for two or more State-like entities to recognise each other as sovereign States as long as they meet the minimum criteria for Statehood. Although the majority of contemporary scholars support this theory, its limitation is also evident because if Statehood was truly declaratory, in the situation of the occupation of a State by the other State, the ending of effective control and independence would in turn mean the extinction of the occupied State. ${ }^{55}$ The State practice in the early twentieth century appeared to endorse constitutive theory, and even at the end of the twentieth century many international courts were also supportive of this theory. ${ }^{56}$ With regard to the manner of recognition, it can be given either expressly or tacitly. In the latter situation, recognition can be provided when an existing State officially enters an intercourse with the new State by sending or receiving a diplomatic envoy, or by concluding a treaty or any other act. ${ }^{57}$

In the case of the Mongolia-Tibetan Treaty, according to constitutive theory, Tibet could not become an independent sovereign State until an existing State gave such recognition, and nor could Mongolia. Furthermore, it also needed to obtain the recognition of the majority of existing States to prove its independent status. ${ }^{58}$ However, this was not the case in Mongolia. Although the Russo-Mongolian Agreement of 1912 was cited to prove Mongolia's treaty-making capacity, ${ }^{59}$ the wording of the Agreement was often misunderstood in explaining the status of Mongolia. According to Article I of the Agreement, 'the Imperial Russian Government shall assist Mongolia to maintain the autonomous regime which she has established'. ${ }^{60}$ Was the phrase of 'the autonomous regime' equivalent to the recognition of Mongolia's independence by Russia? Probably not. First, the Russian expression of the autonomous regime on the Mongolia issue

\footnotetext{
${ }^{54}$ William Worster, Sovereignty - Two Competing Theories of State Recognition, See https://exploringgeopolitics.org/publication_worster_willliam_sovereignty_constitutive_declatory_statehood_reco gnition_legal_view_international_law_court_justice_montevideo_genocide_convention. 
followed the formula of Tibet's internal autonomy which Britain had decided upon. ${ }^{61}$ As discussed in the previous chapter, Britain had no intention of recognising Tibet's independence. ${ }^{62}$ Similarly, there is no reason to consider that Russia had the same intention for Mongolia. Concerning the legal nature of this Russo-Mongolian Agreement, it shared many similarities with the Lhasa Convention. For instance, both of them were agreements signed by local authorities with a foreign State without authorisation from the Central Government of China, and neither of them ever recognised the independence of Tibet or Mongolia in the texts. In this sense, the RussoMongolian Agreement was also a document with an undetermined legal effect rather than a treaty under international law. Its validity depended on whether the Chinese Government gave its retroactive recognition to the rights and obligations of the agreement. Second, soon after the conclusion of the Russo-Mongolian Agreement, Russia and China jointly issued a declaration. Article I of the declaration states that 'Russia recognizes Chinese suzerainty regarding Outer Mongolia', and Article II that 'China recognizes the autonomy of Outer Mongolia'. ${ }^{63}$ Furthermore, in 1915, a tripartite Convention was concluded by Russia, China, and Mongolia in Kyakhta, which recognised Outer Mongolia's internal autonomy (as part of Chinese territory). Mongolia recognised China's suzerainty and could not conclude international treaties with foreign countries regarding political and territorial questions. ${ }^{64}$ In a separate exchange of notes, the Chinese suzerainty was interpreted to mean that Mongolia remained a part of Chinese territory. ${ }^{65}$ Therefore, it is reasonable to argue that the SinoRussian Declaration of 1913 and the Kyakhta Treaty of 1915 denied the recognition of an independent Mongolian State. In addition, after the imperial Russian Government was overthrown in 1917, the Republic of China abolished the autonomy of Outer Mongolia by taking advantage of the Russian Revolution. ${ }^{66}$ In this context, the new Soviet Russia signed a treaty with Republic China, confirming that outer Mongolia was 'an integral part of the Republic of China', and the Soviet Government promised to respect 'China's sovereignty therein' ${ }^{67}$ It can be seen that the so-called 'Mongolian

\footnotetext{
${ }^{61}$ Yuan Yi Zhu, Suzerainty, Semi-Sovereignty, and International Legal Hierarchies on China's Borderlands, Asian Journal of International Law, 2020, pp 1-28.

${ }^{62}$ See Section 4.1.4 in Chapter 4.

${ }^{63}$ Tachibana Makoto, supra n.46, p 185.

${ }^{64}$ Agreement Between China, Russia, and Mongolia, Signed at Kiachta, June 7, 1915. See the American Journal of International Law, Vol. 10, No. 4, Supplement: Official Documents, 1916, pp. 251-256.

${ }^{65}$ Warren W. Smith, Tibetan Nation - A History of Tibetan Nationalism and Sino-Tibetan relations, pp 187-88.

${ }^{66}$ Li Xiaobing, Ethnic China: Identity, Assimilation, and Resistance, Lexington Books, 2015, p 25.

${ }^{67}$ 'Agreement of the General Principles for the Settlement of the Questions Between the Republic of China and the Union of Soviet Socialist Republics.' The Foreign Ministry Archives (referred to below as WCTA), Section 03-32, 
State' has neither been recognised by the Republic of China nor by other members of the international community during the first half of the twentieth century. Consequently, it could hardly be considered as an independent State in international law. As Alfred Rubin rightly pointed out, 'in view of the doubts surrounding the status of Mongolian authority, it cannot be considered a recognition of Tibetan independence by an established member of the community of states. ${ }^{68}$ Similarly, before the MongoliaTibetan Treaty was signed, Tibet also failed to gain the recognition of any existing State of its position as an independent State. In this sense, the Mongolia-Tibetan Treaty can hardly be regarded as a valid treaty in international law, and it cannot be used as evidence of Tibet's independence.

With regard to the attitudes of third States towards the Mongolia-Tibetan Treaty, neither Britain nor Russia recognised the Treaty as valid. As the British were of the opinion that the Dalai Lama did not authorise Dorjiev to sign the Mongolia-Tibetan Treaty, Edward Grey, the British Foreign Secretary expressed to M. Sazonof, the Russian Minister of Foreign Affairs, that the document did not possess any significance in the absence of evidence as to the legal rights of the signatories. ${ }^{69}$ Sazonof informed the British that Dorjiev was a Russian subject and that the Russian Government could not recognise him as the representative of the Dalai Lama. ${ }^{70}$ Concerning Russia's attitude towards the Mongolia-Tibetan Treaty, Sazonof agreed with Grey and pointed out 'as Russia could make no decision with regard to Tibet without an understanding with Great Britain, the Russian Government would regard the agreement as nul et non avenue'. ${ }^{71}$

In conclusion, the so-called 'Mongolia-Tibetan Treaty' is more like a document agreed upon by two parties whose statuses were equally doubtful rather than a treaty in international legal discourse. By examining the Mongolia-related treaties, there is no evidence to prove the independence of Mongolia was ever recognised in their texts. Likewise, Tibet also failed to obtain any recognition of its independence by existing States. From the standpoint of constitutive theory, they can hardly be considered as

Box 495(1). See Bruce A. Elleman, Secret Sino-Soviet Negotiations on Outer Mongolia, 1918-1925, Pacific Affairs, Vol. 66, No. 4, 1993, pp 555-56.

${ }^{68}$ Alfred P. Rubin, The Position of Tibet in International Law, p 123. See also Alfred Rubin, Tibet's Declarations of Independence? the American Journal of International Law, Vol. 60, No. 4, 1966, pp. 812-14.

${ }^{69}$ IOR/L/PS/11/46, Register No. 1581, Sir Edward Grey to Sir G. Buchanan, March 11. 1913.

${ }^{70}$ Ibid, Register No. 632, Sir G. Buchanan to Sir Edward Grey, February 14, 1913.

${ }^{71}$ Ibid, Register No. 319, Sir G. Buchanan to Sir Edward Grey, January 17,1913. 
subjects of international law. In other words, both Tibet and Mongolia lacked the eligibility needed to conclude a treaty. Therefore, the Mongolia-Tibetan Treaty was not a treaty in international law, and it obviously could not constitute proof of Tibet's independence.

\subsubsection{An Analysis of the Dalai Lama's Proclamation of 1913}

Shortly after the Dalai Lama returned to Lhasa, he issued a proclamation to the Tibetans on 14 February 1913. This proclamation is often regarded as the formal declaration of Tibet's independence. ${ }^{72}$ For this reason, an analysis of its nature is given in this section.

According to Shakabpa's record, the contents of the proclamation are as follows:

'I, the Dalai Lama, most omniscient possessor of the Buddhist faith, whose title was conferred by the Lord Buddha's command from the glorious land of India, speaks to you as follows:

I am speaking to all classes of Tibetan people...... During the time of Genghis Khan and Altan Khan of the Mongols, the Ming dynasty of the Chinese, and the Qing dynasty of the Manchus, Tibet and China co-operated on the basis of benefactor and priest relationship. A few years ago, the Chinese authorities in Szechuan and Yunnan endeavoured to colonize our territory. They brought large numbers of troops into central Tibet on the pretext of policing the trade marts. I, therefore, left Lhasa with my ministers for the Indo-Tibetan border, hoping to clarify to the Manchu Emperor that the existing relationship between Tibet and China had been that of patron and priest and had not been based on the subordination of one to the other.

Meanwhile, the Manchu Empire collapsed. The Tibetans were encouraged to expel the Chinese from central Tibet. I, too, returned safely to my rightful and sacred country, and I am now in the course of driving out the remnants of Chinese troops from Do Kham in eastern Tibet. Now, the Chinese intention of colonizing Tibet under the patronpriest relationship has faded like a rainbow in the sky. Having once again achieved for

\footnotetext{
${ }^{72}$ Tsepon W. D. Shakabpa, Tibet: A Political History, Yale University Press, 1967, p 246.
} 
ourselves a period of happiness and peace, I have now allotted to all of you the following duties to be carried out without negligence:

(1) .......

(2) $\ldots \ldots$

(3) $\ldots . .$.

(4) Tibet is a country with rich natural resources, but it is not scientifically advanced like other lands. We are a small, religious, and independent nation......To safeguard and maintain the independence of our country, one and all should voluntarily work hard......

(5) $\ldots . .$.

Your duties to the government and to the people will have been achieved when you have executed all that I have said here. This letter must be posted and proclaimed in every district of Tibet, and a copy kept in the records of the offices in every district. ${ }^{, 73}$

Before analysing whether this proclamation could be considered as the unilateral declaration of Tibet's independence, it is necessary to clarify the (il)legality of unilateral declarations of independence and their legal effects in international law. On the question of whether such unilateral declarations fall within the ambit of international law, there is little academic or legal authority about this issue until the ICJ's opinion on Kosovo. ${ }^{74}$ In this case, the Court concluded that the declaration of Kosovo's independence did not violate the applicable rule of international law. ${ }^{75}$ But the Court did not clarify whether it considered declarations of independence to be legal, or purely political proclamations. In response to the nature of declarations of independence in the case of Kosovo, a number of States considered that such declarations are political facts, and they are not regulated by international law. ${ }^{76}$ In academia, James Crawford also held that secession is a matter that falls within the domestic jurisdiction of the metropolitan State and is not regulated by international law. ${ }^{77}$ If secession is not regulated by international law, then the declaration of independence, as the act of secession, is also not regulated by international law. In this sense, unilateral declarations of independence are legally

\footnotetext{
${ }^{73}$ Ibid. pp 246-48. The first three points are omitted mainly referred to the religious and civil affairs of Tibet.

${ }^{74}$ Accordance with International Law of the Unilateral Declaration of Independence in Respect of Kosovo, Advisory Opinion, 2010 1.C.J. 403, 175 (July 22).

${ }^{75}$ Ibid.

${ }^{76}$ Eva Kassoti, The Sound of One Hand Clapping: Unilateral Declarations of Independence in International Law, German Law Journal, Vol. 17 No. 02, 2016, p 233. See Oral Statements Made During the Public Sitting at the Peace Palace, in the Kosovo Advisory Opinion, C.R. 2009/31, 46 (Dec. 9, 2009), statements of Norway, Jordan, France and US.

${ }^{77}$ James Crawford, Response to Experts Reports of the Amicus Curiae, in Self-determination in International Law: Quebec and Lessons Learned, Martinus Nijhoff Publishers, 2000, pp 153-161.
} 
neutral acts which fall outside the ambit of international law. A declaration of independence does not produce any legal effects not only because it is not regulated by international law, but also because the author of the declaration is a non-State actor rather than a sovereign State, and there is no evidence that international law treats the intention of a non-State actor similarly to that of a sovereign State. ${ }^{78}$ Furthermore, a declaration of independence is a means by which entities put forward claims of Statehood; it is not a means of creating a State under international law because the creation of a State is a matter of fact, and other States may accept or reject it. ${ }^{79}$ Although little reference can be found regarding the legality and effect of declarations of independence in the early twentieth century, the contemporary opinions on this issue to some extent reflected the reality of the past. The most revealing declarations of independence found in the decades after 1850 are the secession proclamations of the States of the Confederacy. For example, in December 1860, the South Carolina Declaration of Secession asserted that South Carolina had resumed her position among the nations of the world, as a separate and independent State. ${ }^{80}$ However, little evidence can be found to prove that the independent status which South Carolina claimed had been recognised individually by other States. On the contrary, the Declaration of Independence of the Czechoslovak Nation of 1918 was hastily recognised by the US and other States. ${ }^{81}$ In this sense, the act of issuing a declaration of independence by itself does not produce the legal effect of creating an independent sovereign State.

Back to the case of Tibet, as declarations of independence intend to change the legal status of the territory whose independence they are declaring, they shall possess certain characteristics. Generally, declarations of independence should be made publicly, either orally or in writing; the audience of such declarations should be subjects of international law rather than only the people of this territory; the intention of pursuing independence should be clear and specific in the content of the declaration. ${ }^{82}$ According to these

\footnotetext{
${ }^{78}$ Eva Kassoti, See also Advisory Opinion of ICJ on the Unilateral Declaration of Independence in Respect of Kosovo, 22 July 2010.

${ }^{79}$ Eva Kassoti, p 233.

${ }^{80}$ David Armitage, The Contagion of Sovereignty: Declarations of Independence since 1776, South African Historical Journal, Vol. 52, 2005, p 14.

${ }^{81}$ Usually, the claimant for international recognition must have obtained possession of definite territory and must have organized a government. But in the case of the recognition of the Czechoslovak nation these conditions have not been fulfilled. In the first place recognition has been accorded, not to a government established in the territory inhabited by the Czechoslovak people, but to a National Council with head- quarters in Washington. See Charles G. Fenwick, Recognition of the Czechoslovak Nation, The American Political Science Review, Vol. 12, No. 4, 1918, pp 715-8.

${ }_{82}$ Although there is no consensus on the constitutional standards of the declarations of independence, the unilateral declarations of States may shed some light on this question. See Guiding Principles applicable to unilateral 
standards, the Dalai Lama's proclamation can hardly be considered as a declaration of Tibet's independence. Despite the proclamation of 1913 being publicly made in writing, it was only directed at Tibetans rather than any other States. For this reason, it can be inferred that the Dalai Lama had no intention of making the Chinese Republican Government, Britain, or Russia aware of this proclamation. As Alfred Rubin pointed out, 'a "declaration" that was kept secret even from the Power whose authority was supposed to be "declared" abrogated would be hard to consider a "declaration of independence" in any sense to the general reader.' ${ }^{83}$ In fact, by analysing the circumstances in which the proclamation was made, it can be found that the Dalai Lama issued this document as a new year's speech to all Tibetans at the beginning of the Water-Ox year (1913). In international practice, the declaration of independence is a significant political document, and existing State practices fail to give any examples to indicate that a State's independent statement can also be a new year's speech. ${ }^{84}$ Furthermore, the terms of a unilateral declaration of independence should explicitly express the intention to secede from the parent State. But it cannot be seen from the text of the proclamation that the Dalai Lama had a strong willingness to describe Tibet as an independent sovereign State. ${ }^{85}$ Therefore, the Dalai Lama's proclamation did not follow the characteristics of a declaration of independence. Even if it were considered as a unilateral declaration under international law, it could not produce any legal right or obligation for Tibet because the creation of a State is a matter of fact. As Goldstein rightly stated, 'Although the proclamation clearly indicated the Dalai Lama's desire for freedom, as well as his intention of ruling Tibet without Chinese interference, it was not precisely a declaration of independence. ${ }^{86}$ Now that neither the Mongolia-Tibetan Treaty nor the Dalai Lama's Proclamation can be used to prove the independent status of Tibet, the next section aims to explore what status Tibet did possess after the Chinese Revolution of 1911.

\subsubsection{Tibet and the Status of the De Facto State}

declarations of States capable of creating legal obligations by International Law Commission, UN Doc A/61/10 (2006).

${ }^{83}$ Alfred Rubin, Tibet's Declarations of Independence? p. 813.

${ }^{84}$ Deng Lie, Study on the Historical and Legal Status of Tibet in International Law, $\mathrm{p} 88$.

${ }^{85}$ Ibid.

${ }^{86}$ Melvyn C. Goldstein, A History of Modern Tibet, 1913-1951: The Demise of the Lamaist State, University of California Press, 1991, p 62. 
With the fall of the Qing Dynasty and the expulsion of Chinese troops from Tibet, the Dalai Lama and the Kashag essentially ruled Tibet without the interference of the Chinese Government from 1912 until 1951. Nevertheless, the Chinese Republican Government claimed that Tibet was part of its territory, although it was no longer under the Republican Government's effective control. By examining the relevant situations in the early Republican era, this section explores what kind of status Tibet possessed during this period.

The first thing to be clear of is whether Tibet became an independent sovereign State after the Chinese Revolution of 1911. With regard to State in international law, it is widely accepted that the State as an international person should possess the following qualifications: (a) a permanent population; (b) a defined territory; (c) a government; and (d) a capacity to enter into relations with other States. ${ }^{87}$ The first three points refer to the internal sovereignty of the State, while the fourth is more concerned with external sovereignty. All existing States, as persons of international law, are in accordance with the aforementioned features. However, is it undoubtedly to conclude that entities that meet with these features must be sovereign States? In theory, entities that meet the first three criteria can be said to have the capacity to interact with other States as long as they are willing to comply with international law. However, there is a gap between whether they should have this capacity and whether they can actually exercise it. The exercise of such a capacity refers to the recognition of a new State by other existing States, because if no existing State is willing to interact with the new State-like entity, then this entity cannot actually exercise its capacity to enter into relations with others. In this sense, the internal sovereignty of a State does not depend upon its recognition by other States. The external sovereignty of a State, on the other hand, may require recognition by other States in order to render it perfect and complete. ${ }^{88}$ According to this constitutive view, the recognition of Statehood by existing States is necessary for the creation of a new State. In the case of Tibet, apart from discussing the internal sovereignty of Tibet, whether such recognition existed constitutes a crucial indicator to determine Tibet's independent status. However, as discussed previously, the MongoliaTibetan Treaty cannot be regarded as such recognition by Mongolia. Additionally, there is also no evidence that any other State ever recognised Tibet as an independent

\footnotetext{
${ }^{87}$ Malcolm N. Shawn, International law, Cambridge University Press, 2017, p 157.

${ }^{88}$ Henry Wheaton, Elements of International Law, Stevens and Sons Limited Press, p 35; 37.
} 
sovereign State. For this reason, Tibet can hardly be an independent sovereign State after the Chinese Revolution of 1911.

Apart from sovereign State, there is another category of entities called de facto States in international law. Nowadays, instead of conflict between sovereign States, the most common type of conflict in the world is between central governments and ethnic minority groups in pursuit of independence. Such kind of internal conflicts aimed at secession often serve as a genuine way of creation and existence of the de facto State. These entities lack external sovereignty but often possess domestic sovereignty, given that they control the population within their territories. Although they look and function like States, they are not recognised as such. The concept of a de facto State has been a constant presence in the post-war international order, but the post-Cold War era has seen a proliferation of such entities. ${ }^{89}$ With regard to the definition of a de facto State, according to Pegg, 'A de facto State exists where there is an organized political leadership which has risen to power through some degree of indigenous capability; receives popular support; and has achieved sufficient capacity to provide governmental services to a given population in a specific territorial area, over which effective control is maintained for a significant period of time. The de facto State views itself as capable of entering into relations with other states, and it seeks full constitutional independence and widespread international recognition as a sovereign State. It is, however, unable to achieve any degree of substantive recognition and therefore remains illegitimate in the eyes of international society. ${ }^{90}$ The main feature of a de facto State is that it enjoys effective control over the territory in question, but the international community does not recognise this control as that of a sovereign State. ${ }^{91}$

With regard to Tibet from 1912 to 1951, the Tibetans expelled all the Chinese officials and soldiers from Tibet by force in 1912. Therefore, it is fair to argue that Tibet got rid of Chinese authority through armed conflict since 1912, which was in line with the way that the de facto State is created. Furthermore, to maintain this secessionary situation, the Tibetan army was engaged in several large-scale armed conflicts with the Chinese army in 1917, 1930 and 1950. Given that the current chapter mainly focuses on the peaceful interactions between the Tibetans and the Chinese, these Sino-Tibetan armed

\footnotetext{
${ }^{89}$ Adrian Florea, De Facto States: Survival and Disappearance (1945-2011), International Studies Quarterly, Volume 61, Issue 2, June 2017, pp 337-351,

${ }^{90}$ S. Pegg, International Society and the De Facto State, Aldershot / Brookfield, 1998, p. 26.

${ }^{91}$ Sergo Turmanidze, Status of the De Facto State in Public International Law, PhD Dissertation, the University of Hamburg, 2010, p 9.
} 
conflicts will be discussed in the next chapter. Moreover, according to Pegg's definition, an organized political leadership constitutes the core element of a de facto State. In the case of Tibet, there is no doubt that it had an established regime exercising a degree of effective centralised administrative and legislative authority. ${ }^{92}$ This regime had the Dalai Lama as the head of the leadership of Tibet, a cabinet of ministers called Kashag to deal with administrative affairs, and a national assembly called Tsongdu. Although this system already existed long ago and was under the supervision of the amban during the Qing Dynasty, it did effectively control Tibet after the amban was expelled in 1912. In the meantime, this effective territorial control by Kashag reached the major area of Tibet, except the eastern Kham, which remained under Chinese rule.

In the meantime, the Chinese Government's position on the situation in Tibet should also be an important factor in analysing Tibet's status. As mentioned, the Qing Government had, to some extent, recovered its sovereignty over Tibet by carrying out a series of reforms during the early twentieth century. Despite this, the question arises when the revolutionaries overthrew the Qing Dynasty and established the Republic of China because, according to Owen Lattimore, 'what existed in fact was a Manchu Empire, of which China formed only one part'. ${ }^{93}$ Confusion has resulted from the careless and, at times, intentional practice of calling the Qing Empire Chinese. ${ }^{94}$ The Revolution of 1911 made the Chinese independent from the Qing Empire, but this has nothing to do with Tibet as it kept a kind of 'priest-patron' relationship with the Qing Empire. ${ }^{95}$ Therefore, what is the relationship between the Qing Empire and the Republic of China, and was the latter entitled to inherit the Qing's sovereignty over the peripheries of the Empire? This question involves whether the relationship between the two was the succession of States or the succession of governments. In other words, compared with the Qing Empire, was the Republic of China a new State or a new government? The answer can be found in the Imperial Decree of Abdication by the Qing Emperor of 1912.

The decree of abdication was a historic moment. It reads as follows:

\footnotetext{
${ }^{92}$ Li Tieh-tseng, Tibet Today and Yesterday, New York: Bookman Associates, 1960, p 130

${ }^{93}$ Owen Lattimore, Studies in Frontier History, New York, 1962, p. 77.

${ }^{94}$ Michael C. van Walt van Praag, The Status of Tibet, $\mathrm{p} 11$.

${ }^{95}$ See Section 2.2.2.2 in Chapter 2.
} 
'The Whole Country is tending towards a republican form of government. It is the Will of Heaven, and it is certain that we could not reject the people's desire for the sake of one family's honor and glory.

We, the emperor, hand over the sovereignty to the people. We decide the form of government to be a constitutional republic.

In this time of transition, in order to unite the South and the North, We appoint Yuan Shih-kai to organize a provisional government, consulting the people's army regarding the union of the five peoples, Manchus, Chinese, Mongolians, Mohammedans, and Tibetans. These peoples jointly constitute the great State of the Republic of China.

We retire to a peaceful life and will enjoy the respectful treatment of the nation. ${ }^{96}$

This decree was a constitutional document which transferred the sovereignty of the Qing Empire to the new Republican Government. From the perspective of international law, the transition between the Qing Empire and the Republic of China was a succession of governments rather than a succession of States; this argument can also be confirmed by the fact that the Republican Government succeeded in the treaties concluded by the Qing Government. In this sense, the Republic of China inherited the Qing's sovereignty over Tibet. Shortly afterwards, Yuan Shih-kai, President of the Republic of China, also stated in his presidential announcement of 12 April 1912 that Tibet, Mongolia, and Xingjiang would be considered provinces of China on an equal footing with the others and as an integral part of the Chinese motherland. ${ }^{97}$ It can be inferred that the Republican Government was reluctant to recognise the independence of Tibet, although it had already lost its effective control over Tibet. For other States, because Great Britain and Russia were bound by the Sino-British Convention of 1906 and the Anglo-Russian Convention of 1907, they only recognised Chinese suzerainty over Tibet. Likewise, they never give the recognition of Tibet as an independent sovereign State. In this sense, it is reasonable to argue that the independent status claimed by the Kashag was not recognised by other States in the international community.

\footnotetext{
${ }^{96}$ Eva March Tappan, ed., China, Japan, and the Islands of the Pacific, Vol. I of The World's Story: A History of the World in Story, Song, and Art, Boston: Houghton Mifflin, 1914, p. 261.

${ }^{97}$ Maria Adele Carrai, Learning Western Techniques of Empire: Republican China and the New Legal Framework for Managing Tibet, pp 813-14. See also Li Tieh-tseng, The Historical Status of Tibet, King's Crown Press, Columbia University,1956, pp 3-12.
} 
In conclusion, since 1912, Kashag, as a de facto government, not only expelled the Chinese influence but also continuously maintained effective territorial control over the majority of Tibet until 1951. In the meantime, it expressed a willingness to rid itself of Chinese rule and sought recognition as a sovereign State. However, no such recognition was given by other States to Tibet's independence. In this sense, Tibet was in accordance with the characteristics of a de facto State as the authority of the Dalai Lama had gained effective territorial control over Tibet, albeit with a lack of recognition from the international community. In the next section, the 1914 Simla Convention between Britain, China, and Tibet is examined to reveal the development of the Republic's position on the status of Tibet in its early period.

\subsection{The Status of Tibet Under the Simla Convention of 1914}

After Russia entered into negotiations with Mongolia in 1912, the British decided to adopt a more active attitude towards the settlement of Tibet's status with the Chinese Republican Government, that is, a situation in which Tibet was autonomous under Chinese suzerainty. ${ }^{98}$ This was not easy to achieve as Britain needed the Republic of China to guarantee that it would not interfere in Tibet's internal affairs. In the meantime, Britain was not allowed to support Tibet directly because it was bound by the AngloRussian Convention of 1907, which prohibited direct contact with Tibet. ${ }^{99}$ Therefore, John Jordan, the British Minister in Peking, sent a memorandum to the Republican Government in the name of coordinating and quelling the Sino-Tibetan conflict in August 1912. In this memorandum, Britain required that China sign a new tripartite agreement between Tibet, China, and Britain. While recognizing China's suzerainty over Tibet, the memorandum stated that Tibet would maintain the right to decide its internal administration, thereby rejecting Chinese sovereignty over Tibet. ${ }^{100}$ The Chinese Republican Government was initially reluctant to attend this Conference. However, the British threatened to withdraw the recognition of the Republican

\footnotetext{
${ }^{98}$ FO 371/1327, 29616, 11 July 1912. The India Office issued a document declaring that: His Majesty’s Government, while they have formally recognized the "suzerain rights" of China in Tibet, have never recognized, and are not prepared to recognize, Chinese sovereignty over that country. His Majesty's Government do not admit the right of China to intervene actively in the internal administration of Tibet.

${ }^{99}$ Amy Kellam, Foreign Devils - Law's Imperial Discourse and the Status of Tibet, PhD Dissertation, SOAS, University of London, 2013, p 147.

${ }^{100}$ FO 371/1328, Memorandum communicated to Wai-chiao Pu by Sir. J. Jordan, enclosed in Jordan to Grey, no. 349, 17 August 1912.
} 
Government and negotiate with Tibet directly without the intermediary of China. ${ }^{101}$ In this context, the Republican Government finally agreed to attend the negotiations. This section examines the Simla Convention, which clarifies the status of Tibet as well as its legal effects.

\subsubsection{The Formation of the Simla Convention}

At the beginning of the tripartite Conference, there were three different views on the Sino-Tibetan relations: The Republican Government claimed that it possessed sovereignty over Tibet; Britain insisted that China only had suzerainty over Tibet; Kashag emphasised that Tibet should be regarded as an independent State. These contradictory claims were presented throughout the Conference in October 1913.

At the first meeting of the Conference, on 13 October 1913, Lonchen Shatra, the Tibetan plenipotentiary submitted a statement that asserted Tibet's status. According to this statement, Tibet and China had never been under each other and would never associate with each other in future. It held that Tibet was an independent State and that the Precious Protector, the Dalai Lama, was the Ruler of Tibet, in all temporal as well as in spiritual affairs. ${ }^{102}$ By contrast, Chen Yifan, the Chinese plenipotentiary, stated that Tibet formed an integral part of the territory of the Republic of China and that Tibet and Great Britain should respect China's rights, which have existed as a consequence of this territorial integrity. The Republic of China engaged not to convert Tibet into a Chinese province, and it reserved the right of appointing a Resident to reside at Lhasa. Tibet's foreign and military affairs were to be guided by China, except for commercial intercourse with Britain. ${ }^{103}$ In order to reconcile the conflicting positions of the Chinese and Tibetan plenipotentiaries, McMahon, the British plenipotentiary, advocated partitioning Tibet into Inner and Outer parts. He specified Chinese suzerainty over Tibet while recognizing the autonomy of Outer Tibet. ${ }^{104}$

\footnotetext{
${ }^{101}$ Warren W. Smith, Tibetan Nation - A History of Tibetan Nationalism and Sino-Tibetan relations, p 190.

${ }^{102}$ Lonchen Shatra's proposal was consisted of six demands: 1 . Tibetan independence; 2 . an indemnity; 3 . the right to denounce the Anglo-Chinese Convention of 1906; 4. the right to amend the Trade Regulations of 1893 and 1908; 5. The return to Tibet of all land as far as Tach'ienlu; and 6. the extension of Tibetan territory so as to include Konokor See The Boundary Question Between China and Tibet: A Valuable Record of the Tripartite Conference Between China, Great Britain and Tibet Held in India, 1913-1914, published in Peking, China, 1940, p3. See the Sino-Tibetan Boundary and the Tibet-India Boundary in the Simla Convention in Map VI in Appendixes.

${ }^{103}$ Ibid, pp 9-10.

${ }^{104}$ Ibid, p 91.
} 
Although the proposal of McMahon caused serious opposition from Chen Yifan, who asserted sovereignty over Tibet, it was not unreasonable for China to accept this expression not only because it had already lost effective control in Tibet, but also because it had already recognised suzerainty over Outer Mongolia in negotiations with Russia. ${ }^{105}$ Meanwhile, McMahon also threatened to withdraw British recognition of Chinese suzerainty from the draft that he put forward, which was equivalent to an acknowledgement of Tibetan independence. Chen finally initialled the draft of the Convention, awaiting confirmation and ratification from the Republican Government. The summary of articles concerning the status of Tibet and Sino-Tibet relations are as follows:

Article II. The Governments of Great Britain and China recognised that Tibet is under the suzerainty of China, and recognised the autonomy of Outer Tibet. They engaged to respect the territorial integrity of Tibet and to abstain from interference in the administration of Outer Tibet, which shall remain in the hands of the Tibetan Government at Lhasa. The Government of China engaged not to convert Tibet into a Chinese province. The Government of Great Britain engages not to annex Tibet or any portion of it.

Article III. The Government of China engaged not to send troops into Outer Tibet, nor to station civil or military officers, nor to establish Chinese colonies there. The Government of Great Britain engaged not to station military or civil officers in Tibet.

Article IV. The Government of China reserved the right to appoint a Resident at Lhasa with a maximum of 300 escorts.

Article V. The Governments of China and Tibet engaged that they would not enter into any negotiations and agreements regarding Tibet with one another, or with any other Power, unless through the intermediary of Great Britain.

Article IX. Tibet was divided into Outer and Inner Tibet. The existing rights of the Tibetan Government in Inner Tibet, which included the power to select and appoint the high priests of monasteries and to retain full control in all matters affecting religious institutions, should be respected by the Governments of China and Great Britain. ${ }^{106}$

\footnotetext{
${ }^{105}$ In Sino-Russian Declaration of 1913, Russia recognized Chinese suzerainty regarding Outer Mongolia, and China recognizes the autonomy of Outer Mongolia. See Tachibana Makoto, p 185.

${ }^{106} \mathrm{FO} / 535 / 17$, No.231, Enclosure 8 .
} 
Although Chen initialled the draft, he also clarified the understanding that to initial and to sign were two separate actions, and he needed definite instructions from the Chinese Government to sign the draft convention. ${ }^{107}$ However, Chen was instructed not to sign the draft convention because the Chinese Government could not accept the proposed frontier between Inner and Outer Tibet. ${ }^{108}$ In the end, no consensus was reached, and the Simla Conference broke up in the summer of 1914, leaving the status of Tibet unsolved.

\subsubsection{The Effects of the Simla Convention on the Status of Tibet}

In the absence of the Chinese signature, the British and Tibetan delegates signed the draft convention without the consent of China on the 3 July 1914. This action not only caused strong protests from Peking, ${ }^{109}$ but made the validity of the Convention questionable.

The first question related to the validity of the Convention is whether the Tibetan delegate could sign the Convention. First, from the perspective of the Republican Government, Tibet was part of Chinese territory, and it had no power to conclude treaties with other States unless approved by the Chinese Government. For this reason, the attendance of the Tibetan plenipotentiary to the Conference could only be explained as a result of approval from the Chinese Government. When the Chinese Government refused to sign the Convention, this approval was also withdrawn, meaning that the Tibetan plenipotentiary's capacity to conclude the Convention was also terminated. ${ }^{110}$ For Great Britain, given that Britain had recognised the Chinese suzerainty, the action of concluding the Convention with Tibet in the absence of the Chinese participation was obviously not in accordance with the spirit of suzerainty, because the suzerain State absorbs the external sovereignty of the vassal State. In other words, the external affairs of Tibet should be in the hands of the Chinese Government. Consequently, the validity of the Simla Convention between Great Britain is not unquestionable in an international legal sense. Second, as Article II of the Anglo-Russian Convention of 1907 explicitly precluded Britain from entering into negotiations with Tibet except through the

\footnotetext{
${ }^{107}$ The Boundary Question Between China and Tibet, pp 141-42.

${ }^{108}$ Ibid, p. 146. Also see Yuan Yi Zhu, supra n.61, p 22.

${ }^{109}$ Ya Hanzhang (牙含章), The Portrait of Dalai Lama (达赖喇嘛传), Huawen Press, 2001, p 208.

${ }^{110}$ Deng Lie, supra $\mathrm{n} .84$, p 96.
} 
intermediary of the Chinese Government, thus the conduct of concluding the Convention with Tibet apparently constituted a breach of Britain's obligation in international law. Although the British might argue that the Chinese Government did not put forward any objection to the participation of the Tibetan plenipotentiary, it did not mean that Britain had not violated its obligations under the Anglo-Russian Convention, especially considering that China had clearly refused to sign the Simla Convention and opposed the conclusion of the Convention by Britain and Tibet. The validity of the Simla Convention between Britain and Tibet is highly related to the status of the Dalai Lama's regime. As discussed previously, due to the denial of Tibet's independent status, the Convention between Britain and Tibet can hardly be regarded as a treaty concluded between sovereign States. But it does not mean the Convention was invalid if the Dalai Lama's regime constituted a certain kind of subject of international law. Considering that the domestic strife may alter the status of the political organsation within a de facto State, the next chapter will explore the legal nature of the Dalai Lama's regime in the context of the Sino-Tibetan armed conflicts. Without the consideration of the validity of the draft of the Simla Convention, the following content only analyses the draft in the light of its text.

Concerning the status of Tibet, the text of the Simla Convention was not unambiguous. According to Article II, Tibet was under the suzerainty of China, while China recognised the autonomy of Outer Tibet and engaged to respect the territorial integrity of Tibet. First of all, the autonomy of Outer Tibet should be clarified. Given that Chinese suzerainty was already specified, the autonomy in the text naturally referred to the internal administration of Outer Tibet. In the meantime, Article IX stipulated that the Tibetan Government only maintained existing religious rights in Inner Tibet, ${ }^{111}$ which meant the internal administration of Inner Tibet remained in the hands of the Chinese Government. The question on how to understand the territorial integrity of Tibet then arises. The notion of Tibet as an integral vassal State was difficult when Outer Tibet was under the suzerainty of China, while Inner Tibet was actually under the sovereignty of China. From this perspective, the draft Convention made the Tibetan Government give up its internal sovereign rights over Inner Tibet.

\footnotetext{
${ }^{111}$ Article IX stipulated that "for the purpose of the present Convention the borders of Tibet, and the boundary between Outer and Inner Tibet, shall be as shown in red and blue respectively on the map attached hereto. Nothing in the present Convention shall be held to prejudice the existing rights of the Tibetan Government in Inner Tibet, which include the power to select and appoint the high priests of monasteries and to retain full control in all matters affecting religious institutions. FO/535/17, No.231, Enclosure 8.
} 
Theoretically speaking, the draft of the Simla Convention at least eliminated the possibility of Tibet as an independent State. Concerning the Chinese suzerainty, the exchange of notes appended to the Convention further clarified that Tibet forms part of Chinese territory. ${ }^{112}$ However, because China refused to sign the Convention, it has been argued that the Chinese failure to agree to the Simla Convention barred China from claiming the benefits of that Convention, including the benefit of the recognition of Chinese suzerainty and territorial interest in Tibet. ${ }^{113}$ This argument is refuted by Rubin. According to him, the facts upon which the recognition of suzerainty depended did not change as a result of the withdrawal of this recognition. ${ }^{114}$ In fact, China's rights over Tibet were not derived from the Simla Convention, and these rights could not be removed because China refused to sign it. Furthermore, given that the Chinese refusal to sign the Convention was based on dissatisfaction with the proposed frontier between Inner and Outer Tibet rather than the rejection of Chinese suzerainty over Tibet, it shows that the suzerainty that the British proposed at Simla was acceptable to the Republican Government for the time being. In contrast with the Qing's insistence on sovereignty over Tibet, the Republican Government demonstrated a concession on the Chinese attitudes towards the notion of suzerainty. China's refusal to sign the draft Convention was as a result of its dissatisfaction with the boundary between inner and outer Tibet, but not the stipulation of suzerainty. Considering that the Republican Government recognised the internal autonomy of outer Mongolia and had already lost its effective control over Tibet, adhering to the illusory sovereignty would not change the reality of Sino-Tibetan relations; on the contrary, it would weaken British support for the newly established Republican Government. Through this concession, the Republican Government not only ensured the continuation of a nominal Chinese title over Tibet but also prevented Tibet from claiming its de jure independence. Besides, it also formed the legal basis for the re-absorption of Tibet. ${ }^{115}$ However, because of China's refusal to sign the draft of the Convention, it is difficult to say that the Republican Government had formally accepted the suzerainty as the appropriate term to describe Sino-Tibetan relations in its official position. In contrast, it insisted on many occasions that China had sovereignty over Tibet. ${ }^{116}$

\footnotetext{
${ }^{112}$ FO/535/17, No.231, Enclosure 8. The notes exchanged are to the following effect: 1 . It is understood by the High Contracting Parties that Tibet forms part of Chinese territory......

${ }^{113}$ Shakabpa, Tibet: A Political History, 256; Michael C. van Walt van Praag, The Status of Tibet, p 138.

${ }^{114}$ Alfred P. Rubin, supra n.50, pp 125-26.

${ }^{115}$ Yuan Yi Zhu, supra n.61, p 26.

${ }^{116}$ For example, after the death of 13th Dalai Lama, Huang Musong (黄慕松) was sent by the Republican Government to Lhasa for a mission of condolence. During the negotiation between him and the Tibetan representative on Sino-Tibetan relations, Huang insisted that in order to exercise full sovereignty over Tibet while
} 


\section{Conclusion}

By carrying out a series of reforms, the Qing Government, to some extent, restored its authority in Tibet in the first decade of the twentieth century. As a consequence, Kham was gradually incorporated into the direct administration of the Qing Government. In U-Tsang, although the attempt to convert Tibet into a province was not fulfilled, the Qing Government's capacity to intervene in Tibet's internal administration had been significantly strengthened. Therefore, it is inappropriate to use suzerainty to describe the Qing's authority over Tibet during the first decade of the twentieth century. From a broader perspective, the Qing Government had largely governed Tibet's internal and external affairs from the 1790s to 1910s, and its relations with Tibet should be defined as sovereignty rather than suzerainty.

After the Chinese Revolution of 1911, the Tibetans expelled the amban and Chinese troops from Tibet. In order to remove the Chinese control, Tibet and Mongolia concluded an agreement in January of 1913. The Dalai Lama subsequently issued a proclamation which was considered to be a declaration of Tibet's independence to the Tibetans in February 1913. These two documents are often cited for manifesting the independent status of Tibet, but their legal validity is questionable. The Mongolia-Tibet Treaty cannot be regarded as a valid treaty in international law because neither Mongolia nor Tibet could be considered as independent sovereign States in international law. The Dalai Lama's proclamation was not a declaration of independence because it lacked the characteristics of the latter. Even if this proclamation were the declaration of Tibet's independence, it could not produce any legal right or obligation in international law. In fact, Tibet can scarcely be regarded as an independent sovereign State after the Chinese Revolution of 1911, considering that no State ever granted such recognition to Tibet. As there existed an established government which exercised effective administrative and legislative control over the majority of Tibet from 1912 to 1951, Tibet was thus in accordance with the definition of a de facto State during this period. Although it in many ways looked and functioned like a sovereign State, it was far from being a State due to the lack of recognition.

respecting Tibetan autonomy, Chinese central government should appoint a high commissioner to be stationed in Tibet as the representative of the Central Government. See H. Lin, Tibet and Nationalist China's Frontiers, Intrigues and Ethnopolitics, 1928-49, UBC Press, 2006, p 338. 
In order to clarify Tibet's status after the demise of the Qing Dynasty, in October 1913, China, Great Britain, and Tibet held a tripartite conference in Simla. As a result of this Conference, the draft of the Convention not only confirmed China's suzerainty but also divided Tibet into Inner and Outer parts according to whether the Tibetan Government had internal autonomy. It caused confusion over its explanations of the relationship between the territorial integrity of Tibet and Chinese suzerainty because both the external and internal administrations of Inner Tibet were still in the hands of the Chinese Government, which contradicted the expression that China only possessed suzerainty over all of Tibet. Besides, given that the Republican Government refused to sign the draft, as well as Great Britain being bound not to negotiate with Tibet except through the intermediary of China in the Anglo-Russian Convention of 1907, the validity of the Simla Convention concluded between Britain and Tibet is highly questionable. Furthermore, China's refusal to sign the Simla did not bar China from claiming its rights over Tibet under that Convention as China's rights over Tibet were not derived from the Simla Convention. Compared with the Qing's claim of sovereignty over Tibet, the Republican Government's position reflected a flexible concession on the Chinese attitude towards suzerainty. By accepting suzerainty over Tibet, the Republican Government successfully prevented the possibility of Tibet's de jure independence, and it gained a guarantee from Great Britain that it would not support the independence of Tibet. More importantly, this concession constituted the legal basis for recovering its sovereignty over Tibet. In this sense, suzerainty was indispensable to China's legal construction of its territory, as well as the maintenance of Chinese sovereignty over Tibet. After discussing the peaceful interactions between the Republican Government and the Dalai Lama's regime during the Republican era, the status of Tibet is defined as a de facto State. However, as a concept describing the unrecognised State-like entities, de facto States themselves are not subject of international law, but this does not prevent the element which constitutes such status from becoming a subject of international law. For this reason, the next chapter will explore the legal nature of the Dalai Lama's regime in international law from 1912 to 1951 in the context of the Sino-Tibetan armed conflicts. 


\section{Chapter 6 The Legal Nature of the Dalai Lama's Regime from the Perspective of Sino-Tibetan Conflicts}

\section{Introduction}

As discussed in the previous chapter, although the Qing Government had steadily implemented its New Policy in Tibet, the Revolution of 1911 unexpectedly disrupted its attempt to transform Tibet into a Chinese province. For the first time in hundreds of years, Tibet got rid of imperial China's control and independently administered its affairs. However, their independence was recognised by neither the Chinese Republican Government nor by any other States. Compared with a sovereign State, Tibet was more like a de facto State in international law from 1912 to 1951. Unlike sovereign States, which form the fundamental subjects of international law, de facto States do not enjoy this status in the eyes of international law because such State-like entities do not meet all the requirements regarding Statehood. However, one should bear in mind that sovereign States are by no means the only subjects of international law, and in some cases, the elements that constitute de facto States may also possess some status in international law as long as they meet certain conditions. Therefore, instead of focusing on Tibet's status under international law, this chapter concentrates on analysing the legal status of the Dalai Lama's regime, the supreme authority that constituted a core element of Tibet's status as a de facto State in the context of Sino-Tibetan armed conflicts from 1912 to 1951 . As mentioned in Chapter 5, internal armed conflicts aimed at secession often serve as a genuine way of creating most de facto States and support their ongoing existence. ${ }^{1}$ In internal armed conflicts, the people who establish an organised political leadership to provide governmental services and to conduct hostilities with the legitimate government of the parent State are rebels in the eyes of the latter and other third States. When the conflict reaches the intensity of civil war, these rebels may satisfy the characteristics of a belligerent, which is considered a temporary and limited subject of international law concerning the application of rules of war, and are recognised by the legitimate government or any third States as having such a status. At this point, the

\footnotetext{
${ }^{1}$ See Chapter 5, Section 5.2.3.
} 
rebel group become a special subject of international law regarding non-international armed conflict, and in the meantime, the separatist State-like entity under the rebels' effective control also meets the criteria of a de facto State. In the case of Tibet, given that a series of armed conflicts broke out between the Chinese army and the Tibetan army from 1912 to 1951, the Dalai Lama's regime, as Tibet's supreme political organisation, which constituted the core element of the de facto State, might have possessed similar status in the hostilities with the Chinese army. For this reason, this chapter aims to answer the question of whether the Dalai Lama's regime met the criteria of a belligerent and whether such status was recognised by the Chinese Government or any third States. The relevance of this chapter lies in deepening the understanding of Tibet's status as a de facto State. Although the concept of de facto States focuses more on the Statehood of the territory ruled by an organised political leadership and the concept of belligerents focuses more on the status of such organised leadership regarding the application of rules of war, when there exists a civil war aimed at secession within a State, the criteria of a de facto State overlap substantially with those of belligerents. Thus, if the Dalai Lama's regime was a belligerent, it means that the separatist entity under its control, namely Tibet, simultaneously satisfied the definition of a de facto State. In the meantime, given that the Dalai Lama's regime concluded a few agreements with Britain in 1914, a question arises regarding how to understand the legal nature of these agreements. As a temporal and limited subject of international law, the concept of a belligerent may provide a new perspective for examining the validities of these agreements if the Dalai Lama's regime can be regarded as such a subject.

To this end, this chapter consists of two sections. In order to provide a legal framework for the chapter, the first section discusses the law regarding belligerents. It first involves the definition of a belligerent, its legal personality and its criteria. And more importantly, it explores whether the Dalai Lama's regime met these criteria. The second section discusses the legal status of the Dalai Lama's regime from the perspective of the recognition of belligerency. Based on a general understanding of the recognition of belligerency and how it can be attained, this section examines whether such recognition had ever been granted to the Dalai Lama's regime either by the Chinese Government or by any third States, including Great Britain, the United States, India, etc. To achieve the above goals, a legal framework on the law governing belligerents and their recognition should be established in the first place. The relevant theories, legal documents and State practices before the 1950s are introduced and compared to provide readers with a good 
knowledge of what a belligerent is in international law and what role the recognition of belligerency serves in internal armed conflict. After that, a historical approach is applied to examine whether the Dalai Lama's regime was in accordance with the definition of a belligerent and whether the Chinese Government or any third States recognised the former as a belligerent explicitly or implicitly. Therefore, the archives related to SinoTibetan relations that serve as secondary sources were collected and studied from the Second Historical Archives of China and the Archives of Tibet Autonomous Region. Likewise, the archives relating to Sino-Tibetan conflicts from the India Office Record were also selected and used to explain the position of Great Britain and other States on Sino-Tibetan relation. By applying the law governing belligerents and their recognition to the relevant historical facts in the context of Sino-Tibetan conflicts, it can be seen whether the Dalai Lama's regime possessed a certain status under international law and whether such status was ever recognised by any existing States.

\subsection{Sino-Tibetan Wars and the Nature of the Dalai Lama's Regime in International Law}

Before examining the armed conflicts between the Chinese and the Tibetans, it is necessary to build a general legal framework for this chapter, that is, the law governing belligerents and their recognition. For this purpose, the definition of a belligerent and its legal personality are discussed in this section. After that, the characteristics of the Dalai Lama's regime are compared with the above legal discussion to examine whether it conformed with the criteria of a belligerent in the context of Sino-Tibetan conflicts.

\subsubsection{The Concept of a Belligerent and its Legal Personality}

Traditionally, the wars regulated by international law are mainly international armed conflicts, that is, wars between sovereign States. As for non-international armed conflicts, according to the territorial sovereign of the State, questions of peace and order within a State are generally considered as matters within the exclusive competence of that State. The established government in the State traditionally treated rebels as common criminals, but when disturbance within a State reaches a certain intensity of violence that affects the rights and interest of a foreign State, the matter becomes not 
only a question of internal order but also a question of which international law should be applied. By the nineteenth century, the theoretical distinction between internal and international armed conflict did not necessarily reflect the practice of States because the legal status of internal armed conflict could be fundamentally changed by invoking the doctrine of belligerency. ${ }^{2}$

In international law, a violent challenge to the established government can be classified into three different stages according to its scale and intensity: rebellion, insurgency and belligerency. ${ }^{3}$ Rebellion was a modest challenge by a small group of people intent on attaining control. Traditionally, considering that an uprising could be effectively suppressed under municipal law, people who participated in a rebellion had no rights or protection in international law. ${ }^{4}$ Insurgency refers to a more substantial attack against the legitimate order of the State; the rebels are sufficiently organised and they form a threat in their hostilities with the established government. In some cases, foreign States may acknowledge the factual situation to protect their own interests. But such recognition confers no formal status on either party. ${ }^{5}$ The final stage is reached when the conflict between insurgents and established government attains such a sustained level that both sides are entitled to be treated in the same way as contending parties in an international armed conflict through recognition of the insurgents as a belligerent power. Through this recognition, a body of individuals receives an international position as it is in some respects treated as though it were a subject of international law. ${ }^{6}$ The concept of a belligerent is closely related to the situation when the insurrection has assumed the proportion of a civil war in a legal sense, in which insurgents are politically organised under a responsible government exercising sovereign powers over a definite territory and having the will and capacity to fulfil its obligations. ${ }^{7}$ And only when the above conditions arising from the civil war have been reached can the legitimate government of the parent State or third Powers recognise the contention between the legitimate government and the insurgents as a war in the sense of international law and

\footnotetext{
${ }^{2}$ Lindsay Moir, The Law of Internal Armed Conflict, Cambridge University Press, 2002, pp 3-4.

${ }^{3}$ Heather A. Wilson, International Law and the Use of Force by National Liberation Movements, Oxford University Press, 1988, pp 22-29.

${ }^{4}$ Ibid.

${ }^{5}$ Hersch Lauterpacht, Recognition in International Law, Cambridge University Press, 1947, pp 270-71; Norman J. Padelford, International Law and Diplomacy in the Spanish Civil Strife, The Macmillan Company, 1939, pp 196200.

${ }^{6}$ L. Oppenheim, International Law: A Treatise. Volume 2, London: Longmans, 1920, p 75.

${ }^{7}$ Amos S. Hershey, The Essentials of International Public Law and Organization, New York: The Macmillan Company, 1927, p 119-20.
} 
the insurgents as entitled to the rights and duties of belligerents by the rules of international law concerning the conduct of hostilities. ${ }^{8}$

With regard to the belligerent community's legal personality, legal scholars did not reach a unanimous opinion before the twentieth century. Some publicists argue that a State alone is entitled to wage war, and only States can become the lawful participants of war. Therefore, armed contentions between opposing groups within a State for secession or for obtaining the power of the State are not wars. According to Oppenheim, a belligerent community has no real international personality, and it is only treated as though it were an international person when it is recognised as belligerent. ${ }^{9}$ Similarly, Hall argued that a belligerent 'is not itself a legal person' ${ }^{10}$ On the other hand, other writers expressly support the legal personality of the belligerent. Hershey believed that in addition to States, the belligerent is the only exception to enjoy an international personality because it is 'an inchoate or embryonic State', which is entitled to all the rights and duties of a State as far as the conduct of war is concerned when recognised. ${ }^{11}$ Lawrence held the same view, and he explicitly admitted that the civilised belligerent is a subject of international law, albeit only in a limited and imperfect manner. ${ }^{12}$

The weakness of the opinion of those who denied the legal personality of the belligerent community is obvious. Although they refused to recognise that the belligerent community has a legal personality, they did not object to the application of international law regarding warfare to it. ${ }^{13}$ It is self-contradictory to deny a belligerent community's international personality while admitting that it enjoys rights and is subject to duties under international law because something that is not a legal person is non-existent in the eyes of the law. ${ }^{14}$ Therefore, if they recognised that a belligerent community could

\footnotetext{
${ }^{8}$ Yair M. Lootsteen, The Concept of Belligerency in International Law, no. 166, Military Law Review, 2000, p 109; Vernon A. O'Rourke, Recognition of Belligerency and the Spanish War, Vol. 31, No. 3, American Journal of International Law, 1937, p 400.

${ }^{9}$ L. Oppenheim, Volume 1, p 126.

${ }^{10}$ Hall further argued that 'a society claiming only to be belligerent, and not have permanently established its independence, can have no rights under international law. It cannot, therefore, demand to be recognised upon legal grounds, and recognition, when it takes place, either on the part of a foreign government or of that against which the revolt is directed, is from the legal point of view a concession of pure grace.' See W. E. Hall, A Treatise on International Law, Oxford: The Clarendon Press, 1909, p 23.

${ }^{11}$ Hershey, p 157.

${ }^{12}$ T. J. Lawrence, The Principles of International Law, Boston: D.C. Heath \& Co, 1923, pp 64-5.

${ }^{13}$ According to Oppenheim, full sovereign States alone possess the legal qualification to become belligerents. However, he also added that "whenever a State lacking the legal qualification to make war nevertheless actually makes war, it is a belligerent, the contention is real war, and all the rules of International Law respecting warfare apply to it." See L. Oppenheim, pp 196-7.

${ }^{14}$ Ti-chiang Chen, The International law of Recognition, With Special Reference to Practice in Great Britain and the United States, New York: Frederick A. Praeger Inc., 1951, p 306.
} 
exercise rights and fulfil duties regarding the law of war, they should also admit that it possessed an international personality. In practice, Britain and the United States granted belligerence rights to the South American States in the conflict between Spain and its American colonies by placing them on the same footing in the early nineteenth century. ${ }^{15}$ Likewise, in the American Civil War, Britain placed the Confederate States on an equal footing with the American Government through a declaration of neutrality. ${ }^{16}$ The practice of Britain and the United States indicates that the insurgents, as the undertakers of rights and duties regarding the rules of war, had been placed on an equal footing with the government of parent States by third States through the recognition of belligerency. Therefore, it can be reasonably argued that the belligerents' legal personality was affirmed in the eyes of the above States in the nineteenth century. In the meantime, the above practice also indicated that the recognition of the existing State is closely associated with the acquisition of belligerent status for insurgents. For this reason, a discussion on the recognition of belligerency will be carried out in the next section. The following content explores what conditions the insurgents should meet before they are recognised as belligerents.

\subsubsection{The Criteria of a Belligerent Community}

With the application of modern international humanitarian law since the 1950s, the concept of a belligerent is of peripheral importance nowadays. The doctrine of a belligerent and its recognition began to take shape in the early nineteenth century through the practice of Great Britain and the United States in the conflict of the Spanish American colonies. ${ }^{17}$ And it became a mature system during the American Civil War, which rendered customary international law regarding war applicable between the parties in the conflict and third States. As for the criteria for a belligerent, the US Supreme Court once gave its opinion in the Prize Case during the Civil War. It argued that 'when the party in rebellion occupy and hold in a hostile manner a certain portion of territory, have declared their independence, have cast off their allegiance, have organised armies, have commenced hostilities against their former sovereign, the world

\footnotetext{
${ }^{15}$ The Foreign Office legal officer stated that, 'Considering the principles of neutrality that have been professed on the part of this Country, the asserted independent Governments would have a right to exercise the ordinary privileges of War in maritime capture. See note 25 in Lindsay Moir, The Law of Internal Armed Conflict, Cambridge University Press, 2002, p 7.

${ }^{16}$ Ibid, p 9.

${ }^{17}$ Ibid, p 6.
} 
acknowledges them as belligerents, and the contest a war'. ${ }^{18}$ Similarly, the 1900 resolution of the Institute of International Law set out three-element criteria for third States to make their choice regarding the recognition of belligerency. It included 'the existence within a State of a widely spread armed conflict; the occupation and administration by rebels of a substantial portion of territory; the conduct of hostilities in accordance with the rules of war and through armed force responsible to an identifiable authority'. ${ }^{19}$ Furthermore, a memorandum by the Foreign Office of Britain also revealed the same opinion in regard to the conflict of the Formosa Strait in $1957 .{ }^{20}$ It can be seen from the above judicial decision and legal opinions that the criteria for a belligerent contain at least four elements: the aim pursued by insurgents must be political; the existence of civil war within a State, beyond the scope of local unrest; the insurgents must occupy a substantial part of the territory of the State and exercise effective control over people and things in that territory; the hostilities must be conducted under the rules of war and through organised armed forces acting under a responsible authority. ${ }^{21}$

Firstly, whether it is to overthrow the established government or secede from the parent State, the purpose of rebels should be political to distinguish it from criminals or pirates. ${ }^{22}$ Although the action of rebels certainly violates the municipal laws of the State in civil war, no breach of international law occurs through the mere fact of a rebel group attempting to overthrow the legitimate government of the State or to secede from the State. $^{23}$

Secondly, to determine whether the rebellious situation has reached the stage of belligerency, it requires the armed conflict between rebel groups and the established government to spread over the partial or overall territory of the parent State, thus

\footnotetext{
${ }^{18}$ The Prize Case, 67 U.S. 635 1863. See Cases Argued and Decided in the Supreme Court of the United States, Book 17, The Lawyers' Cooperative Publishing Company, 1901, p 476.

${ }^{19}$ Institute of International Law, Resolution on Rights and Duties of Foreign Powers as Regards the Established and Recognized Governments in Case of Insurrection, Neuchatel meeting, September 8, 1900. See Robert McLaughlin, Recognition of Belligerency and the Law of Armed Conflict, Oxford University Press, 2020, pp 75-6. The above criteria are summarized by Rosalyn Higgins in The International Regulation of Civil Wars, Thames \& Hudson, 1972, pp 170-71.

${ }^{20}$ Cabinet Paper-Belligerency in the Formosa Strait: Memorandum by the Foreign Office, Annex A, in U. Archives File:FO 371/120939, see Robert McLaughlin, p 76.

${ }^{21}$ Dana's edition of Wheaton, Elements of International Law (1866), Oxford: The Clarendon Press, 1866, p. 34, note. 15; Yair M. Lootsteen, p 109.

${ }^{22}$ Robert D. Powers, Insurgency and the Law of Nations, the Judge Advocate General of the Navy (JAG) Journal, Vol. 16, Issue 4 (May 1962), p 55.

${ }^{23}$ R. P. Dhokalia, Civil Wars and International law, Indian Journal of International Law, 219, 1971. p 225. 
reaching the level of civil war. The scale and scope of the armed conflict are relevant to the recognition of belligerency. In the case of insurgency, the armed conflict may not reach the level of civil war, and the established government of the parent State or third States usually refuse to recognise the insurgents as belligerents. For example, in the Polish rebellion in the mid-nineteenth century, the insurgent forces were much smaller and far less organised than the adversary imperial Russian army, therefore the Polish insurgents were never ultimately recognised as belligerents. ${ }^{24}$ On the other hand, in the American Civil War, more than three million people participated in the armed conflict and single battles involved casualties in the tens of thousands, and the belligerency of the Confederate States was widely recognised by the American Federal Government and other third States. ${ }^{25}$ In this sense, the scale and scope of the armed conflict to some extent determine the existing States' discretion to give their recognition to insurgents.

Thirdly, the insurgents must occupy a considerable portion of the parent State's territory and must be able to maintain law and order in the territory under its control. Although the military nature of the belligerent is always in the first place, its capacity as a civil government to exploit resources, raise men and supply materials cannot be ignored. A belligerent enjoys actual supremacy in the territory under its control and people living there must submit to such supremacy. With regard to the legal capacity of belligerent communities in relation to the legitimate government of the State and third States, Smith believes that 'once the decision has been taken to recognise an insurgent government as belligerent, the legal consequences of the decision are not limited to its rights of acting hostility. So long as it maintains an independent existence, the insurgent government is considered to have all the normal rights and liabilities of a State. ${ }^{26}$ His argument to some point reflected the practice of the State in the late nineteenth century. In the case of Baldy v Hunter, which occurred thirty years after the American Civil War, the Court was asked to determine whether transactions between persons residing within the territory dominated by the government of the Confederate States were unlawful for the reason only that they occurred under the sanction of the laws of that government. ${ }^{27}$ The Court decided that these transactions were not invalid, and the Court's decision

\footnotetext{
${ }^{24}$ Robert McLaughlin, p 77.

${ }^{25}$ Ibid.

${ }^{26}$ H. A. Smith, Great Britain and the Law of Nations, Vol. 1, London: P.S. King, 1932, p 325; see also, Some Problems of the Spanish Civil War, the British Year Book of International Law, 18, 1937.

${ }^{27}$ Baldy v. Hunter, United States Supreme Court 171 U.S. 388 (1898).
} 
may be regarded as the view of the United States in respect of the acts of belligerents within the territory under their control. ${ }^{28}$

Lastly, the insurgents must conduct hostilities in accordance with the laws of war through armed forces under a responsible authority. This criterion may lead to a logical dilemma for those scholars who advocate that the insurgents take no right and no duty under international law until they are recognised as belligerents. ${ }^{29}$ Because the observance of the laws of war requires the insurgents to possess the capacity to exercise the rights and duties of war before the recognition, while the above view denies that the insurgents can have any rights until they are recognised as belligerents, which reveals a logical contradiction. Therefore, the observance of the laws of war should serve as a criterion for determining the existence of belligerents rather than the rights and duties imposed by the recognition. As for the rules of engagement, these mainly involve restrictions on means of warfare, humanitarian treatment of prisoners of war and their exchanges, and the conclusion of a truce agreement, etc.

With regard to the relationship between de facto State and belligerent, as discussed in the previous chapter, a de facto State exists where there is an organised political leadership that has risen to power through some degree of indigenous capability, receives popular support and has achieved sufficient capacity to provide governmental services to a given population in a specific territorial area, over which effective control is maintained for a significant period of time. ${ }^{30}$ Likewise, in the situation of civil war aimed at secession, the rebels recognised as belligerents are also organised in the form of political leadership, which exercises the supreme authority within a certain portion of the parent State by virtue of its military capabilities. Such a political organisation also functions as a civil government and receives the support of people in the territory under its control. In this sense, the separatist State-like entity under the control of

\footnotetext{
${ }^{28} \mathrm{Ibid}$, according to the decision of the court, '...... within such territory, the preservation of order, the maintenance of police regulations, the prosecution of crimes, the protection of property, the enforcement of contracts, the celebration of marriages, the settlement of estates and the transfer and descent of property, and similar subjects were, during the war, under the control of the local governments constituting the so-called Confederate States....... what occurred or was done in respect of such matters under the authority of the laws of these local de facto governments should not be disregarded or held to be invalid merely because those governments were organized in hostility to the Union established by the national Constitution, this, because the existence of war between the United States and the Confederate States did not relieve those who were within the insurrectionary lines from the necessity of civil obedience, nor destroy the bonds of society, nor do away with civil government or the regular administration of the laws......'

${ }^{29}$ William E. Hall, A Treaties of International Law, Oxford University Press, 1924, p 36; Lassa Oppenheim, International Law, Vol. II, Longmans, 1906, ss 74, 75, 76.

${ }^{30}$ See Section 5.2.3 of Chapter 5. Also see Scott Pegg, International Society and the De Facto State, the PhD thesis submitted to the Department of Political Science of the University of British Columbia, 1997, pp 37-8.
} 
belligerents to a certain extent can also be a de facto State, although such status is not relevant to the subject of international law.

After introducing the definition of a belligerent and its relationship with a de facto State, the following discussion examines whether the Dalai Lama's regime can be regarded as belligerent in its hostile relations with the Chinese Government during the Republican period.

\subsubsection{The Nature of the Dalai Lama's Regime Under the Criteria of a Belligerent}

Before discussing Sino-Tibetan armed conflicts, it is necessary to give a brief description of the region of Kham, where Sino-Tibetan conflicts broke out. It mainly involves the establishment of Sikang Province there.

\subsubsection{The Establishment of Sikang Province}

The Revolution in 1911 not only ended the Qing's rule in Lhasa but also significantly weakened the Chinese influence in the frontier area between Tibet and Szechuan, traditionally called 'Kham'. As mentioned in the previous chapter, the majority of inhabitants in Kham were Tibetans and maintained close ties with Lhasa. Against this background, their chieftains maintained relative independence from the latter, and meanwhile, they also received hereditary titles bestowed by the Qing Government. ${ }^{31}$ This situation had lasted until 1905 when the Qing Government carried out its New Policy in Kham. Through a series of reforms aimed at consolidating the Chinese influence, the Qing Government gradually incorporated Kham into its direct administration. It was against this background that $\mathrm{Fu}$ Songmu (傅嵩炑), the commissioner of Szechuan-Yunnan affairs, suggested that the Qing Court to turn Kham into a province. Fu's memorial became the origin of Sikang Province. ${ }^{32}$ However, the collapse of the Qing Dynasty disrupted the plan of establishing Sikang Province. On

\footnotetext{
${ }^{31}$ See Section 5.1.1 in Chapter 5.

${ }^{32}$ Fu Songmu's Memorial for the Establishment of Sikang Province (傅嵩炑请建西康行省折),1911/6/16, in the Historical materials of Sichuan Yunnan border affairs archives in the late Qing Dynasty (清末川滇边务档案史料), pp 1032-35.
} 
the other hand, the Tibetan army marched east and occupied most of the Kham region by taking advantage of turbulent situations in Szechuan. ${ }^{33}$ In response to the Tibetan invasion, the Chinese Republican Government appointed Yin Changheng (尹昌衡), the General Governor of Szechuan, as the commander of the Tibet expedition to reclaim Chinese sovereignty over Tibet. With the support of the Central Government, General Yin quickly recaptured Tachienlu, Batang and Litang in Kham. ${ }^{34}$ When Yin was about to march his troops towards central Tibet, Sir John Jordan, the British Minister in Peking, brought pressure on President Yuan Shih-kai, urging him to withdraw the expedition in exchange for British recognition of the Republican Regime and financial aid. ${ }^{35}$ Because the Chinese Republic was a newly established government that badly needed international recognition, President Yuan finally ordered Yin to revoke his Tibetan expedition. ${ }^{36}$

After General Yin recovered Chinese control in most of the Kham area, in 1913, the Republican Government, in order to strengthen the tranquillity of the Szechuan-Tibet frontier, decided to set up the Special Administrative Region of Szechuan frontier (川 边特别行政区), which was under the jurisdiction of the governor of Szechuan. ${ }^{37}$ But in 1917, the Tibetan Government sent troops to Kham again and rapidly conquered dozens of counties. Subsequently, more than half of the counties of the Special Administrative Region of Szechuan frontier were under the control of the Tibetan army. ${ }^{38}$ The 1917 Sino-Tibetan conflicts made Kham was often in a state of war, and the proposal of establishing a province in Kham was suspended. In 1925, the Republican Government decided to change the name of the Special Administrative Region of Szechuan frontier to the Sikang Special Administrative Region. After that, Sikang had formally become the official name of Kham in an administrative sense. ${ }^{39}$

\footnotetext{
${ }^{33}$ The Tibetan army occupied Chamdo(昌都) and repeatedly invaded Dege(德格), Shiqu(石渠), and there are only seven counties were still in the hands of Szechuan Government after the conflict. See Wang Yongbin (王永斌), the Study on the Establishment of Sikang Province and Its Historical Role(论西康建省及其历史作用), the dissertation of Tibet University of Nationalities, 2012, p 33.

${ }^{34}$ Xin Yulin (辛宇玲), the Study on the Establishment of Sikang Province (西康建省研究), the dissertation of Minzu University of China, 2005, pp 17-8.

${ }^{35}$ FO/535/15, No. 90, John to Grey, 8 June, 1912; PEF, 1912,69 No. 3460/12, John to Grey, 17 August 1912.

${ }^{36}$ Wu Fengpei (吴丰培), the Telegraph of Tibetan Affairs in the First Year of Chinese Republic (民元藏事电稿), Xi Zang Renmin Press, 1983, p 40.

${ }^{37}$ Yang Zhonghua (杨仲华), Xikang Jiyao (西康纪要) vol.2, Shangwu Yinshuguan (商务印书馆), 1937, p 365.

${ }^{38}$ Wang Haibing (王海兵), Game of Power in the Process of Sikang Provincialization (西康省制化进程中的权力 博亦), China’s Borderland History and Geography Studies (中国边疆史地研究), Vol.18 No.3, 2008, pp 19-20.

${ }^{39}$ From 1930 to 1932, the Sino-Tibetan conflict broke again in Kham. The Chinese army, composed of Muslim and Han soldiers, led by Ma Bufang and Liu Wenhui defeated the Tibetan army and recovered the territories in the east bank of Jinsha River, which Tibet had held since 1919, while the Tibetan forces would remain west bank of Jinsha 
In the early years of the Republic, most of China was, in fact, under the rule of warlords. Although these warlords were subordinated to the Central Government in a legal sense, their rule over the frontier provinces was actually independent of the Central Government, whereas the President only kept a weak influence over those provincial governments. In the case of Sikang, after undergoing frequent forcible annexation, General Liu Wenhui (刘文辉) finally controlled Sikang and Szechuan Province. Liu, at first, did not pay much attention to the development of Sikang. But after he was expelled from Szechuan by Liu Xiang (刘湘), the other influential warlord in that province, he had no choice but to focus on Sikang. For this reason, he tried to seek the support of the Central Government by establishing Sikang Province. ${ }^{40}$

Throughout the 1920s, some profound changes had taken place in China's political situation after the North Expedition. ${ }^{41}$ The Kuomintang (Chinese Nationalist Party) replaced the Peking Government and established the Nationalist Government in Nanking. In response to Liu's proposal, President Chiang Kai-shek, out of the need to balance the Szechuan warlords, agreed with him to set up a committee for the establishment of Sikang Province in $1934 .{ }^{42}$ Meanwhile, the breakout of the SinoJapanese War in 1937 also facilitated the provincialization of Sikang. As the Central Government moved the capital from Nanking to Chongqing, the strategic value of Sikang had rose significantly. For one thing, an organised Sikang Province could serve as the base for anti-Japanese war; for another, this province could to some extent deter the Tibetan's ambition for independence. ${ }^{43}$ Therefore, the Central Government decreed that the Government of Sikang Province would be formally established on the first day of $1939 .{ }^{44}$ When Sikang Province was established, it consisted of 46 counties. However, at that time, the thirteen counties on the west bank of the Jinsha River were under the control of Lhasa. This situation made Sikang Province the front line of Sino-Tibetan

River. See Melvyn C. Goldstein, A History of Modern Tibet, 1913-1951: The Demise of the Lamaist State, University of California Press, 1991, p 221- 3.

${ }^{40}$ Wang Yongbin, supra n.33, p 38.

${ }^{41}$ The North Expedition was a military campaign in China waged by nationalist forces under the leadership of Chiang Kai-shek to extend their power from their base in southern China to much of northern China by defeating local warlord armies. As the consequence of the Expedition, a nationalist government was established in Nanjing in 1928. ${ }^{42}$ Wang Chuan (王川), The Establishment of Western Kham Province and Its Significance (近代民族关系史上的 西康建省及其历史意义), Journal of Tibet University, Vol.23 No.1, p 38.

${ }^{43}$ Liu Wenhui (刘文辉), The Theory and Practice of Building a New Sikang (建设新西康之理论与实际), in Kangdao Yuekan (康导月刊), 1944, vol 5, no.10.

${ }^{44}$ Selected Archives of Modern Kham District (近代康区档案资料选编), by Sichuan Institute of Nationalities (四 川民族研究所), 1990, p 89. 
conflicts during the Republican era, and the Jinsha River had roughly become the actual line of control for the two hostile sides.

After discussing the history and development of the battlefield of Sino-Tibetan conflicts, the following discussion analyses the characteristics of the Dalai Lama's regime. In order to examine whether this regime was in accordance with the definition of a belligerent, the following factors are taken into consideration: the intensity of the conflicts, the behaviour of the warring parties, the territory under insurgents' effective control, the insurrectional organisation as a de facto government and the aim of the insurrectional organisation. In the Section 6.1.3.2, the relevant historical facts in SinoTibetan conflicts are listed to determine whether these conflicts had reached the intensity of civil war in the first half of the twentieth century. More importantly, the Tibetan and the Chinese armies' behaviour during the conflicts is examined to judge whether the laws of war were obeyed in the hostilities. Section 6.1.3.3 shows how many territories were under the Dalai Lama regime's effective control. Section 6.1.3.4 explains whether this regime was able to maintain law and order in the territory under its control. Finally, the goal pursued by this regime is presented in Section 6.1.3.5.

\subsubsection{Sino-Tibetan Armed Conflicts and Behaviours of Hostile Parties}

There were four major armed conflicts between the Dalai Lama's regime and the Chinese Government in the first half of the twentieth century: Yin Changheng's Tibetan Expedition in 1912, the Riwoche incident of 1917, the Beri dispute in 1930 and the Battle of Chamdo in 1950. By describing the process of these conflicts, certain historical facts are mentioned and analysed to examine whether the Dalai Lama's regime followed the laws of war in the conflicts and whether these conflicts reached the intensity of civil war.

(1) Yin Changheng's Tibetan Expedition in 1912

By taking advantage of the chaotic political situation after the Chinese Revolution, the previous chieftains and lamas abolished by the Qing Government began to revolt 
against the Chinese at the instigation of the Dalai Lama. ${ }^{45}$ Soon afterwards, the Tibetan army seized Dingxiang (定乡), cutting off the communication between Kham and Szechuan, and then surrounded Batang and Chamdo. The fierce attack of the Tibetan army put Tachienlu, the strategic point of Kham, in a dangerous situation. Until July 1912, only eleven of the thirty-four counties of Kham were still in the hands of the Chinese army. ${ }^{46}$ To recover the Chinese control over Kham, the Republican Government ordered Yin Changheng, the General Governor of Szechuan, to initiate a military expedition against the Tibetan army. Meanwhile, the Governor of Yunnan Province was required to send troops to Tibet to support Yin's expedition. ${ }^{47}$ The expedition had two goals: one was to sweep Tibetan troops away from Kham; the other was to rescue the disarmed Chinese forces in Lhasa and bring Tibet back into the family of the five races. ${ }^{48}$ In July 1912, Yin divided his 2,500 soldiers into two divisions. One division marched along the northern road to Chamdo through Dawu, Kantze and Derge. The other, under the leadership of Yin, marched south through Litang, Batang and Draya. ${ }^{49}$ After a series of victories in August, Yin had driven the Tibetan troops out of Kham and prepared to march to Lhasa.

For fear of British interference, the Chinese Foreign Minister Lu Zhengxiang (陆征祥) presented a note to the British ambassador Jordan, claiming that the purpose of the Chinese army entering Tibet was to suppress the rebellion and hoping Britain would be neutral on this matter. ${ }^{50}$ However, the successive victories achieved by Yin inevitably aroused British concern over the Tibetan autonomy under Chinese suzerainty. Considering that the new Chinese Republican Government in early 1912 was badly in need of international recognition and loans, Jordan warned President Yuan Shih-kai that His Majesty's Government could not give the Republican Government financial assistance if the expedition went beyond Chinese territory. ${ }^{51}$ On 17 August 1912, Jordan further delivered a memorandum on the Tibet question to the Republican Government

\footnotetext{
${ }^{45}$ The Telegraph of Tibetan Affairs in the First Year of Chinese Republic, Xi Zang Renmin Press, 1983, p 139.

${ }^{46}$ The Record of Tibet Case (藏案纪略), written by the Foreign Ministry of Republic of China (北洋政府外交部 编),1912, p 25. See the Map of Kham During the Republican Era in Map VII in Appendixes.

${ }^{47}$ Ibid., The Telegraph of Tibetan Affairs in the First Year of Chinese Republic, p 11.

${ }^{48}$ FO/535/15, no. 67, Jordan to Grey, 27 April 1912. The family of the five races or Five Races Under One Union (五族共和) was one of the major principles upon which the Republic of China was founded in 1911 at the time of the Xinhai Revolution. Its central tenet was the harmonious existence under one nation of what were considered the five major ethnic groups in China: the Han, the Manchus, the Mongols, the Tibetans, and the Hui.

${ }^{49}$ Lamb, the Mcmahon Line: A Study in the Relations between India China and Tibet, 1904 to 1914, University of Toronto Press, 1966, p 404.

${ }^{50}$ Zhu Xiu (朱绣), Sixty-Year Chronology of Tibet (西藏六十年大事记), Qinghai People's Press (青海人民出版 社), 1996, p 30.

${ }^{51} \mathrm{FO} / 535 / 15$, Enclosure in no. I50, Jordan's memo on 23 June, 1912.
} 
with the following points: the British Government, while recognising Chinese suzerainty in Tibet, denied that the Republic of China had any right to intervene in Tibetan internal administration beyond Article I of the Anglo-Chinese Convention of 1906. Therefore, the Chinese actions in Tibet since 1910, when they began to take over the Tibetan internal administration, and Yuan Shih-kai's Presidential Order of 21 April 1912, had breached the above Convention and should be repudiated. ${ }^{52}$ Consequently, the British Government required a written declaration as a condition precedent to extending their recognition of the Chinese Republican Government. ${ }^{53}$ President Yuan Shih-kai, facing pressure from the British, telegraphed Yin to cancel the expedition. ${ }^{54}$ With the withdrawal of Yin's expedition, the first Sino-Tibetan armed conflict during the Republican era ended. Due to the lack of records on the detailed activities of the two sides, it is difficult to judge whether they had complied with the laws of war in the conflict of 1912.

(2) The Riwoche Incident and the Second Sino-Tibetan War of 1917

Since the Simla Conference of 1914, the Dalai Lama had hoped the British would exert pressure on the Republican Government to ratify the draft of the Simla Convention, but the negative attitude of the Chinese had made him doubt the credibility of the British. It was against this background that the Tibetan Government decided to expand its army to resist the Chinese military campaign. Between 1914 and 1917, the Tibetan Government bought a large number of weapons and ammunition from the British Indian Government. ${ }^{55}$ With the help of the British, a modern military school was set up in Gyantse in 1915. Through a series of reforms, the strength of the Tibetan army had been significantly reinforced before the second Sino-Tibetan war.

In June 1917, Chinese soldiers captured two Tibetan soldiers who were collecting forage grasses across the border in Riwoche, which is close to Chamdo. The Tibetan commander, the Kalon Lama, stationed nearby requested General Peng Jih-sheng (彭日

\footnotetext{
${ }^{52}$ Yuan Shih-kai's Order referred to Tibet was to be "regarded as on an equal footing with the Provinces of China Proper". See Compilation of Historical Archives of the Relationship between Tibet and the Central Government since the Yuan Dynasty (元以来西藏地方与中央政府关系档案史料汇编), vol.6, compiled by the second historical archives of China, p 2346.

${ }^{53} \mathrm{FO} / 535 / 15$, Enclosure in no. 193, memorandum communicated to Wai-chiao Pu by Sir. Jordan, 17 August, 1912. See also Lamb, the Mcmahon Line, p 435.

${ }^{54}$ The Telegraph of Tibetan Affairs in the First Year of Chinese Republic, p 45; 71; 84;90.

${ }^{55} \mathrm{FO} / 535 / 17$, Enclosure in no. 231, Final memorandum of the Tibet Conference, 8 July, 1914; FO/535/18, no.43, Sir Edward Grey to Sir J. Jordan, 5 October, 1915; FO/535/20, no. 15, 16, Communications between the India Office and Foreign Office, 11, 12 December 1917.
} 
昇), the Chinese commander in Chamdo, to release these two Tibetan soldiers. However, his request was rejected by the latter. ${ }^{56}$ Subsequently, the second Sino-Tibetan war broke out. With the benefit of modern weapons, the Tibetan army had quickly captured Riwoche and Chagyab before they surrounded Chamdo. In April 1918, General Peng surrendered and became a prisoner of the Kalon Lama. After the Tibetans occupied Chamdo, the Chinese prisoners were treated well: eleven officers and one thousand four hundred soldiers were disarmed and imprisoned; all of them were sent to Lhasa along with a military escort; rice and clothes were provided to them on the way to Lhasa; General Peng was allowed to carry whatever private possessions he had; and when the conflict was terminated, they were released and returned to Yunnan Province via Burma. ${ }^{57}$ As an important branch of the law governing war, the humane treatment of prisoners of war originated in the eighteenth century. ${ }^{58}$ During the nineteenth century, the principle that prisoners of war should be treated by their captor analogously to his own troops became generally recognised. The Hague Regulations of 1899 further clarified the rules regarding prisoners of war. At the beginning of the twentieth century, the regulations were adopted again by the Hague Regulations of 1907, so these regulations constituted the law governing the subject in the early twentieth century. ${ }^{59}$ These rules included the following: prisoners of war were under the power of the government of the captor; they had to be humanely treated, and the government was bound under all circumstances to maintain them and prepare quarters, food and clothing for them on the same footing as for its own troops; all their personal belongings, except arms, horses and military papers, remained their property; the repatriation of prisoners of war had to take place as speedily as possible when the war ended. ${ }^{60}$ It can be seen from the above historical facts that General Peng and his soldiers, as the captives of the Kalon Lama, were treated humanely after they surrendered to the Tibetan army. Once the conflict was suspended, the Chinese soldiers were released and repatriated as

\footnotetext{
${ }^{56}$ According to the Chinese source, the two Tibetan soldiers were executed by the General Peng. But Shakabpa in his Advanced Political History of Tibet argued that "When they (the two Tibetans) left for Chamdo from Riwoche accompanied by fifty Chinese soldiers, Tibetan soldiers were lying in wait, and they snatched the Tibetans from the Chinese. See Archives of the Mongolian and Tibetan Institute of the Republic of China (民国政府蒙藏院档案), 1045/388, 1 November,1918. See also Tsepon W. D. Shakabpa, One Hundred Thousand Moons: An Advanced Political History of Tibet, Vol. 2, Brill, 2010, p 789.

${ }^{57}$ Tsepon W. D. Shakabpa, p793.

${ }^{58}$ For example, the Treaty of Friendship concluded in 1785 between Prussia and the United States of America is probably the first that stipulates (article 24) a proper treatment of prisoners of war, prohibiting confinement in convict prisons and the use of irons, and ordering confinement for them in a healthy place, where they can have exercise, and where they are kept and fed as troops. See L. Oppenheim, International Law, Vol. II, London: Longmans, 1920, p 131.

${ }^{59}$ Wheaton's Elements of International Law, London: Stevens and Sons Limited, 1916, p 478.

${ }^{60}$ See Article 4 to 20 of the Hague Regulations respecting the Laws and Customs of War on Land of 1907.
} 
quickly as possible. Therefore, although the Tibetan army may not have heard of the laws regarding the treatment of prisoners of war at that time, their behaviour based on traditional war customs was in line with these laws.

By the end of April 1918, the Kalon Lama had not only captured Riwoche, Chamdo, Draya and Markham but had also occupied Derge and most of Nyarong. The Dalai Lama expected him to advance to Tachienlu and bring the whole of Kham under Lhasa's control. But the Kalon Lama did not act rashly when he realised that his military strength was limited. ${ }^{61}$ In early 1918, the gravity of the situation in Chamdo also attracted the attention of the British. For the purpose of obtaining reliable news of SinoTibetan conflict, Eric Teichman, a British consular officer in Chengdu, decided to go to the front line where he might find an opportunity to mediate between the two sides and reach a truce agreement. ${ }^{62}$ In the absence of the request for mediation from either the Chinese or the Tibetans, Teichman reached Chamdo and discussed with the Kalon Lama the question of a possible truce. ${ }^{63}$ After receiving the Kalon Lama's positive reply, Teichman managed to persuade General Liu Tsan-ting (刘赞廷), the garrison commander of Batang, to act as the Chinese representative in the proposed negotiation with the Kalon Lama. But as a local commander, he participated in the negotiation without authorisation from his superior, so Liu's representative qualification was questionable, and it led to the second round of negotiations in October $1918 .{ }^{64}$ Owing to the willingness of both parties to reach a settlement, General Liu and the Kalon Lama signed a truce agreement under the mediation of Teichman on 19 August 1918. The truce contained thirteen articles, which included the following points: the arrangement was temporary and would remain in force until a final and permanent tripartite settlement between China, Britain and Tibet was reached; it was agreed that there should be a provisional ceasefire line between the Chinese and Tibetan armies along the current line of control - as a result, no Tibetan troops should be stationed to the east of the Jinsha River, and likewise, Chinese troops should not cross to the west of the

\footnotetext{
${ }^{61}$ Lamb, Tibet, China \& India, 1914-1950: a history of imperial diplomacy, Roxford Books, 1989, p 57-8.

${ }^{62}$ Ibid, pp 60-1. Teichman had enough motivation to do so, for one thing, his participation could pre-empt an attempt by any Chinese official, to arrive at some direct Sino-Tibetan arrangement without British participation; for another, if his plan worked it would become the ground for some future resumption of formal negotiations along the lines of the Simla Conference of 1913-1914 in which a permanent solution to the problem of the eastern frontiers of Tibet would be found.

${ }^{63}$ Liu Tsan-ting, the Actual Situation of Sino-Tibetan War and Negotiations from 1917 to 1918 (民六民七年康藏战 争及交涉之实况) in Kangzang Qianfeng (康藏前锋), Vol.2, no.1, 1934, pp 43-5.

${ }^{64}$ Ibid, p 62. Teichman had expected to go to Batang where lie hoped to obtain by telegraph from the Szechuan Government some form of official credentials for General Liu; but Teichman discovered that there no longer existed any rapid communication between that place and Tachienlu, the telegraph line having been cut. And being. In any case, General Liu maintained that he possessed all the powers needed to negotiate a binding cease-fire.
} 
Jinsha River; all the Chinese prisoners in the hands of the Tibetans, and all the Tibetan prisoners in the hands of the Chinese, should be released and permitted to return home if they desired to do so; in the event of any dispute arising between the Tibetan and Chinese authorities on the frontier, there should be no resort to arms; but both sides agreed to refer matters in dispute to the British Consul for his arbitration. ${ }^{65}$

After the conclusion of the agreement, the war between the Chinese and Tibetans continued because the qualification of Liu was not recognised by his superior, Chen Hsia-ling (陈遐龄), the Frontier Commissioner. Therefore, Teichman had to go to Rongbatsa to get the signature of Chen Hsia-ling or someone who was authorised to sign on behalf of the Frontier Commissioner. On 10 October 1918, a supplementary agreement was finally signed between Han Kuang-chun (韩光钧), who represented General Chen Hsia-ling and the Kenchung Lama, Chungrang and Drentong Dapons on behalf of the Kalon Lama. Unlike the agreement in Chamdo, the Rongbatsa agreement was bipartite because Teichman no longer described himself as the representative of the British Government but as a witness and middleman. Furthermore, the Rongbatsa agreement lacked a detailed geographical description of the intended truce line. It only stipulated that the Chinese troops should withdraw to Kantze, and the Tibetan troops should withdraw to the boundary of Derge district. And both the Chinese and the Tibetans undertook not to advance their forces along either the Northern or Southern Roads and ceased all hostilities for a year from 17 October 1918. Similarly to the Chamdo agreement, the Rongbatsa agreement only stipulated the mutual withdrawal of troops and cessation of hostilities and was not a definite settlement of the questions at issue. ${ }^{66}$ After the Rongbatsa agreement was signed, both Chinese and Tibetan troops withdrew from the areas specified in the agreement. Therefore, the second Sino-Tibetan came to an end.

After the outbreak of war, the engagement may be suspended due to various needs. The suspension of hostilities can be achieved by means of a truce or armistice. The rules regarding armistices are stipulated in Articles 36 to 41 of the 1907 Hague Regulations. With regard to the definition of a truce or armistice, Oppenheim argued that 'truces or armistices are all agreements of belligerent forces facing each other for a temporary

\footnotetext{
${ }^{65}$ Archives of the Mongolian and Tibetan Institute of the Republic of China, 1045/388, 1 November, 1918; See also IOR/L/PS/10/714, E. Teichman to Jordan, 21 August of 1918.

${ }^{66}$ Han Kuang-chun, A Record of the Sino-Tibetan Armistice Negotiations in the Seventh Year of the Republic of China (民国七年汉藏构兵停战交涉纪实) in Bian Zheng (边政), Vol. 7, 1931; See also IOR/L/PS/10/714, Enclosure 3 of Teichman to Jordan, 11 October of 1918.
} 
cessation of hostilities for some purpose or another. ${ }^{67}$ There are three different kinds of armistice: a suspension of arms, a general armistice and a partial armistice. An agreement to cease hostilities within a limited area, for a short time, and with the objective of carrying out a definite purpose is generally called a 'suspension of arms'. A similar agreement, extending over a very long period and applying to the whole field of warfare, is called a 'general armistice'. A partial armistice is between a suspension of arms and a general armistice, and it is concluded by hostile parties for a considerable part of their forces and the region of war, and not for momentary purposes. ${ }^{68}$ As for the competence to conclude armistices, every commander has the power to conclude an armistice regarding the forces and places under his immediate control, but a general armistice covering the whole field of hostilities can be made only by the supreme power of hostile parties. ${ }^{69}$ An armistice generally contains a clear announcement of the exact time when it begins and ends. If the matter is not stipulated, an armistice commences the moment it is completed. If no definite time has been fixed for the suspension of hostilities, the armistice ceases after the notification. In the case of Sino-Tibetan conflict, as the commander-in-chief of the Tibetan army, the Kalon Lama and his representatives concluded two agreements with the Chinese commanders to suspend the hostilities in Kham. These agreements clarified the way to achieve the suspension of hostilities and indicated the temporary nature of cessation. Considering that the agreements were applied to the conflict in Kham and little evidence reveals that the Kalon Lama's contracting act reflected the will of Lhasa, therefore, these two agreements are more in accordance with the features of a partial armistice from the perspective of laws regarding the subject.

(3) The Beri Dispute and Sino-Tibetan War of 1930

The third Sino-Tibetan War originated in the areas between Beri and Dargye, where the ceasefire line of 1918 passed through them. According to the Rongbatsa agreement, the Chinese had the right to the garrison in Beri. However, Article V of the Chamdo agreement also stipulated that the control of all the monasteries and all matters appertaining to the Buddhist religion should be in the hands of the Dalai Lama. The crisis started when the chief of Beri seized the estates of the incarnate lama of Nyarong

\footnotetext{
${ }^{67}$ L. Oppenheim, p 243.

${ }^{68}$ Ibid., pp 243-6. Also see T. J. Lawrence, Principles of International Law, D. C. Heath \& Co. Publishers, 1900, p 455 .

${ }^{69}$ Lawrence, Ibid.
} 
monastery in Beri, who had received his training at Dargye monastery. Consequently, the incarnation fled to Dargye and hoped that the monks there would help regain the temple property. The Dargye monks called for help from the local Tibetan commander, and the latter provided them with arms. In June 1930, the monks of Dargye monastery seized Nyarong monastery. Therefore, the chief of Beri asked the Chinese troops in Rongbatsa to intervene in the dispute. In response, the Targye monks requested Lhasa to send the Tibetan troops of Kham to help them. The Tibetan army in Derge was sent to Beri and drove out the Chinese army there. ${ }^{70}$ In February 1931, a severe conflict broke out again. The Tibetans pushed forward rapidly, capturing a large part of the territory on the east bank of the Jinsha River, including Rongbatsa, Kantze and Nyarong, which are only a few days away from Tachienlu. ${ }^{71}$

Shortly after the outbreak of the conflict, at the request of the Dalai Lama, Chiang Kaishek (蒋介石), the President of the Nationalist Government in Nanking, sent Tang Kosan (唐柯三) and Liu Tsan-ting to the conflict area to negotiate with the Tibetans. However, no substantive truce was reached in Kantze between Liu Tsan-ting and Kalon Ngabo, the Tibetan commander in Kham. ${ }^{72}$ On the other hand, General Liu Wenhui (刘 文辉), the Chinese commander-in-chief of Sikang, was opposed to negotiations with the Tibetans. He regrouped his forces and counterattacked the Tibetan army. By August 1932, he had captured Dargye, Kanze, Nyarong, Rongbatsa and Derge, which Tibet had held since 1919. ${ }^{73}$ For Tibetans, the situation deteriorated when Ma Bu-fang (马步芳), the Muslim warlord of Qinghai Province, decided to advance into Jyekundo, which is in the southern part of Qinghai Province and was occupied by the Tibetans in early 1932. At this point, the second front line of Sino-Tibetan war was formed on the QinghaiTibet border. However, the situation against the Tibetan army soon changed when Liu Xiang (刘湘), the warlord in Chongqing, attacked Liu Wenhui’s forces in Szechuan, which made it impossible for the latter to fight against the Tibetans.

\footnotetext{
${ }^{70}$ Melvyn C. Goldstein, A History of Modern Tibet, 1913-1951: The Demise of the Lamaist State, University of California Press, 1991, p 221.

${ }^{71}$ See Liu Wenhui's telegraph to the Executive Yuan on the attacks of Tibetans and the retreat of Chinese army to Kantze (刘文辉为报藏军大举进攻川军退守甘孜请令达赖撤回藏兵听候调处事致行政院电), 21 March of 1931, 1 (2) - 423, in Collected Archives on Tibet and Tibetan Affairs Stored by the Second Historical Archives of China (中国第二历史档案馆所存西藏和藏事档案汇编).

${ }^{72}$ Ibid, the order from the Mongolian and Tibetan Affairs Commission to Tang Ko-san requiring Liu Tsan-ting to negotiate with the Tibetans (蒙藏委员会就中央关注东北外患西陲防务暂令和缓处置仍由刘赞廷妥为交涉致 唐柯三电),28 October of 1931,141-3692; Tang Ko-san's telegraph to the Mongolian and Tibetan Affairs Commission on the draft of eight points agreement for solving the Dargye-Beri conflict (唐柯三为呈报与琼让议 订解决大白事件八项条件致蒙藏委员会电),7 November of 1931,141-3693.

${ }^{73}$ Ibid, See Liu Wenhui's telegraph to Chiang Kai-shek, 13 July of 1932, 1 (2)-422; Letter form the Government of Szechuan to the Mongolian and Tibetan Affairs Commission, 7 August of 1932, 141-3803.
} 
In order to end the hostility as soon as possible, Liu Wenhui signed a truce with the Tibetans in Gangtuo on 8 October 1932. According to this truce, the effective TibetSikang frontier should be divided in the upper reaches of the Jinsha River, and the Tibetan forces would remain on the west side of the Jinsha River and the Chinese would stay on the east side; meanwhile the Tibetans would give up their occupation of Derge and Rongbatsa, which they had gained in $1918 .{ }^{74}$ Similarly, in April 1933, another truce was signed between the representative of $\mathrm{Ma} \mathrm{Bu}$-fang and the local Tibetan commander, which created a buffer zone between his territory and that held by Lhasa for exchanging prisoners. ${ }^{75}$ After concluding these two truce agreements, the wars between the Tibetans and Sikang and Qinghai came to an end. It can be seen from the above historical facts that the rules regarding prisoners of war and armistices were also implemented in Sino-Tibetan armed conflict of 1930.

(4) The Battle of Chamdo of 1950

In 1949, the political situation of China underwent a radical change as the Chinese communists overthrew the rule of the Nationalist Government and established the People's Republic Government. Considering that Tibet had still maintained its de facto independence until 1951, for the convenience of discussion, the period from 1949 to 1951 was incorporated into the Republican era in a broader sense.

At the beginning of the establishment of the People's Republic Government, the leaders of the Government tried to negotiate with the Tibetan Government over Sino-Tibetan relations in future, but Lhasa replied to the new communist regime negatively. In order to prevent military operations from the Chinese communist army, the Tibetan Government deployed more than half of their total force (about 8,000 troops) around Chamdo to prevent the Chinese army from entering Tibet. For this reason, the Chinese Central Government decided to recover Tibet by force. In July 1950, the Chinese communist army first attacked the Tibetans in Denge, a village about 100 miles northeast of Chamdo, and destroyed the Tibetan wireless transmitters there. On 5 October, the Chinese forces crossed the Jinsha River and attacked the Tibetan garrisons near

\footnotetext{
${ }^{74}$ Ibid, the report from the Mongolian and Tibetan Affairs Commission to Chiang Kai-shek on the contents of the truce in Gangtuo, 23 March of 1934, 141-3809.

${ }^{75}$ Ibid, the report from the Government of Qinghai Province to the Central Government on the photograph of the truce of 1933, 7 October of 1933, 1 (2)-420.
} 
Chamdo. Two weeks later, with the surrender of Ngapoi, the Tibetan Governor-General in Kham, Chamdo was occupied by the Chinese army. ${ }^{76}$ During the Battle of Chamdo, each side maintained military discipline well and treated each other's prisoners properly. For example, in the preparations for the battle, the Chinese troops were under strict orders not to requisition even a cup of tea from local Tibetan people; they were instructed to obtain the local Tibetans' assent and pay in silver coins if they needed animals or food. Furthermore, the Chinese troops were asked to obey a military proclamation called 'Three General Rules and Eight Things to Keep in Mind'. ${ }^{77}$ After Chamdo was seized, the Chinese served Kalon Ngapoi and his soldiers a big meal with meat and vegetables. After that, the Tibetan officials were all sent back to Chamdo and placed under house arrest. When the Battle of Chamdo was over, each of the Tibetan soldiers was repatriated home immediately and given a silver coin as travel expenses. ${ }^{78}$ On 29 April 1951, the Tibetan representatives led by Ngapoi and the Chinese representatives led by Li Weihan (李维汉) started negotiations in Peking and reached a draft agreement on 23 May 1951, which as known as the 'Agreement between the Central People's Government and the Local Government of Tibet on the Measures for the Peaceful Liberation of Tibet (or the Seventeen Point Agreement for the Peaceful Liberation of Tibet for short).' After discussing the matter with his senior officials, the $14^{\text {th }}$ Dalai Lama decided to accept the agreement. Since then, Tibet has been under the administration of the People's Republic Government. According to the Geneva Convention of 1949, plunders and reprisals against civilians and their property are prohibited in war. ${ }^{79}$ During the Battle of Chamdo, the Chinese army was ordered not to take anything from the Tibetan civilians, and they had to pay the right price if they needed to get necessities. Moreover, the Tibetan prisoners were treated humanely by the Chinese army, and they were repatriated quickly when the conflicts ended. Thus, the Chinese army carried out the Geneva Convention governing the treatment of prisoners of war. ${ }^{80}$

\footnotetext{
${ }^{76}$ Jiang Taihua (姜太华), Into the Liberation War (走进解放战争), Vol. 2, China Literature and Art Press (中国文 艺出版社), 2009, p 503. See Attack Routes of the People's Liberation Army in Map VIII in Appendixes.

${ }^{77}$ The Three General Rules: 1. You must obey orders. 2. You cannot take even one needle from the masses. 3. You must turn over to the government things acquired from the enemy. The Eight Things to Keep in Mind: 1. You must speak gently to the people. 2. You must buy and sell honestly. 3. You must return the things you borrow. 4. Things which are broken or lost must be replaced. 5. You may not beat or scold people. 6. You may not destroy or harm the crops. 7. You must not tease or bother females. 8. You may not abuse prisoners of war. See Melvyn C. Goldstein, $p$ 644.

${ }^{78}$ Ibid, p 696.

${ }^{79}$ Article 33 of Geneva Convention relative to the Protection of Civilian Persons in Time of War, 1949.

${ }^{80}$ See Article 13, 15, 118 of Geneva Convention Relative to the Treatment of Prisoners of War, 1949.
} 
Based on the above discussion, it can be seen that both the Tibetan and Chinese armies had fundamentally carried out the laws regarding war in the first half of the twentieth century. But did these Sino-Tibetan conflicts amount to civil war? Although there are no clear criteria for civil wars in international law, now that civil wars can be called 'wars' in the eyes of international law, they should also possess the main characteristics of wars between States. War is contention between two or more States through their armed forces for the purpose of overpowering each other. ${ }^{81}$ In the case of domestic strife, a civil war exists when two opposing parties within a State have recourse to arms to obtain power in the State or when a large fraction of the population of a State takes up arms against the legitimate government. ${ }^{82}$ To determine whether the condition of things is a civil war, the existence of a de facto organisation of the insurgents and the actual employment of military forces on each side, acting in accordance with the rules and customs of war, are tested as the two elements of civil war. ${ }^{83}$ As for Sino-Tibetan armed conflicts, they were by no means ordinary rebellions that could be suppressed by police for the Chinese Government. To prevent the Tibetans from expanding their territory and becoming independent, the Chinese Government had to order the Chinese army in the provinces surrounding Tibet to fight against the Tibetan armed forces. As for the Tibetans, in order to get rid of the Chinese control, they had assembled a modern army under the leadership of the Dalai Lama's regime, even though their numbers were fewer than those of the Chinese army. More importantly, these Sino-Tibetan conflicts had lasted intermittently for forty years, and both parties complied with the rules of war to the greatest possible extent. Therefore, it is reasonable to argue that the conflicts between the Tibetans and the Chinese reached the intensity of civil war.

\subsubsection{The Territory of the Dalai Lama's Regime}

After discovering that Sino-Tibetan conflicts reached the intensity of civil war and the laws governing war were carried out in the hostilities, the following part examines whether a substantial part of the territory of China was under the rule of the Dalai Lama's regime during this period.

\footnotetext{
${ }^{81}$ L. Oppenheim, p 56.

${ }^{82}$ Ibid., p 65.

${ }^{83}$ Lawrence, p 411-2.
} 
In Tibetan history, Tibet was traditionally divided into the regions of U-Tsang (Central Tibet), Amdo (Northern Tibet) and Kham (Eastern Tibet). ${ }^{84}$ After the Chinese Revolution, U-Tsang, the region that formed the borders of the current Tibetan Autonomous Region, was under the rule of the Dalai Lama. However, his influence in Amdo was replaced by Islamic warlords represented by Ma Bufang, who nominally accepted the Republic of China's authority. In 1928, Qinghai Province was created by the Republican Government and Amdo became part of that province. In Kham, the upper reaches of the Jinsha River became the de facto boundary between the Tibetans and the Chinese during the Republican era. The Tibetans occupied the lands of the west bank, and the Chinese took the east. This boundary had been confirmed as the ceasefire line between the Tibetans and the Chinese in the truce agreement of Chamdo in 1918. Through listing the above facts, it can be seen that the region of U-Tsang and part of Kham were under the effective control of the Dalai Lama's regime. The regime met the requirement of a belligerent regarding the control of a considerable portion of the territory of the parent State.

\subsubsection{The Dalai Lama's Regime as a De facto Civil Government}

Apart from holding a considerable territory, whether this regime was able to maintain law and order in the territory was also an important element in the formation of a belligerent. The Kashag, as the governing council of Tibet during the Qing Dynasty and post-Qing period until the 1950s, was set by the Qianlong Emperor through the decree of the 13-Article Ordinance for the More Effective Governing of Tibet in 1751. After that, the Qing Government had regarded the Kashag as the legitimate local government assisting ambans and the Dalai Lama in Tibet's civil administration. After the collapse of the Qing Dynasty, the $13^{\text {th }}$ Dalai Lama returned to Lhasa, and for the first time, he led both religious and administrative affairs without restrictions from the Chinese Government. This new situation paved the way for Tibet to seek its independence.

During the Republican era, the $13^{\text {th }}$ Dalai Lama mainly governed Tibet through the Kashag Government, which consisted of three temporal officials and one monk official. Each of them held the title of Kalon. In the structure of the Tibetan Government, the

\footnotetext{
${ }^{84}$ Rongxing Guo, A Brief History of Tibet, in China's Regional Development and Tibet, Springer, pp 1-19. 
Dalai Lama was at the head of this political system. He had ultimate authority over all decisions and appointments, and all recommendations for action had to be submitted to him for approval. ${ }^{85}$ The highest government beneath the Dalai Lama was the Kashag. As the administrative centre of Tibet, the Kashag received all secular information and telegrams and sent each item to the appropriate office. No civil matter could reach the Dalai Lama without the examination of the Kashag, and the Kashag's seal was required for most formal orders of the government. In addition, it also initiated surveys, investigations and new policies, and submitted advice for promotions and demotions of lay officials to the Dalai Lama. ${ }^{86}$

The function of the Kashag as a civil government was represented in many aspects during the Republican era. In economic terms, in order to mint Tibet's own currency, the Kashag had established some mints and combined them into a large mint in the north of Lhasa in $1931 ;{ }^{87}$ for the purpose of resolving the expenses for the expansion of armaments, the Dalai Lama established the financial resources investigation office, which made a large number of landowning families pay taxes to the Kashag directly; from 1923 to 1929, the Kashag checked all the manor shares and redistributed the taxation of the manor lords. ${ }^{88}$ In terms of civil affairs, the Kashag established the Lhasa telegraph office in 1920, set up the wire from Lhasa to Gyantse in 1922 and opened the post office in $1925 .{ }^{89}$ Before the Chinese Revolution in 1911, the Kashag Government had long been regarded as the legitimate local government of Tibet by the Qing Court. However, when the $13^{\text {th }}$ Dalai Lama decided to free Tibet from China's control after the collapse of the Qing, the Kashag became a de facto government not only responsible for all affairs within its control but also for fighting the Chinese army. It can be seen from the above historical facts that as a de facto government, the Kashag, under the leadership of the $13^{\text {th }}$ Dalai Lama, was able to maintain law and order over the territory under its control.

\footnotetext{
${ }^{85}$ Melvyn C. Goldstein, p 11. When a Dalai Lama dies and his incarnation is a minor, a regent rules in his place. regents were incarnate lamas selected by the National Assembly and theoretically the regent's authority was the same as that of the Dalai Lama. Another important position of the government was lonchen, whose main function was to transmit officials' advices to the Dalai Lama.

${ }^{86}$ Ibid, pp 13-4.

${ }^{87}$ Luo Shaoming (罗绍明), The Study on the Tibet Policy During the Republic of China (民国时期西藏政策研究), the doctoral dissertation of Southwest University for Nationalities, 2013, p 56.

${ }^{88}$ See Tibetan Social and Historical Survey Data Series Editing Group (西藏社会历史调查资料丛刊编辑组), Tibetan Social History Survey (藏族社会历史调查), Vol. 3, Xizang Renmin Press, 1989, p 43.

${ }^{89}$ Luo Shaoming, p 55.
} 


\subsubsection{The Political Pursuit of the Dalai Lama's Regime}

In general, the purpose of belligerents must be political. They either seek to overthrow the established government or secede from the parent State. As for the case of Tibet, in early 1913 , the $13^{\text {th }}$ Dalai Lama issued a proclamation to all his officials and subjects throughout Tibet. Although this proclamation should not be considered as the declaration of Tibet's independence, it did reflect the Dalai Lama's desire to rule Tibet without Chinese interference. When the $13^{\text {th }}$ Dalai Lama died in 1933, the Nationalist Government send Huang Musong (黄慕松) as a special envoy to attend the Dalai Lama's memorial ceremony and to persuade the Kashag to accept that Tibet was a member of the Republic of China. However, in the reply of the Kashag, the Tibetans claimed that Tibet was independent and would deal with its external affairs without the interference of China, and the Tibetan Government would correspond with other States, headed by the British Government, whenever they wished. Moreover, the Kashag refused the proposal to post a Chinese officer at Lhasa. ${ }^{90}$ It can be seen from the above activities that the Dalai Lama's regime aimed to maintain the de facto independence of Tibet from the Chinese authority and ultimately to realise Tibet's de jure independence with the support of Britain and other foreign States. In this sense, the goal pursued by the Dalai Lama's regime was to secede from China rather than for personal gain.

In conclusion, from the perspective of criteria on belligerents, it is reasonable to argue that the Dalai Lama's regime was basically in accordance with the requirements of a belligerent in the hostilities with the Chinese army. As a result, while Tibet continued to be a de facto State during the Republican period, the Dalai Lama's regime, as the political and military leadership in this region, had become a subject of international law with a temporary and limited legal personality. However, according to the constitutive doctrine, insurgents can only become belligerents after they are recognised either by the parent State or third States. Therefore, the next section discusses the legal nature of recognition of belligerency and its functions in determining belligerents. In addition, it also explores whether such recognition was ever granted to the Dalai Lama's regime by the Chinese Government or any third States in the context of Sino-Tibetan wars.

\footnotetext{
${ }^{90}$ Melvyn C. Goldstein, p 236-7.
} 


\subsection{The Legal Nature of the Dalai Lama's Regime from the Perspective of Recognition of Belligerency}

The recognition of belligerency usually refers to recognising, either by the de jure government of the parent State or third States, that the parties in a civil war are entitled to exercise belligerent rights. For both the de jure government of the parent State and third States, the act of recognition was a purely discretionary matter. A State whose interests were affected was free to decide whether it wished to be neutral in the conflict or not. ${ }^{91}$ For the legitimate government, the individuals involved in the civil war, after falling into the hands of the legitimate government, must not be treated as criminals for treason and murder but must be treated as prisoners of war according to the rules of international law. Third States are required to adopt a neutral position to the belligerent and the legitimate government. Meanwhile, the legitimate government releases itself from all responsibility for events that happen in the territory under the control of the belligerent, and the government of the belligerent is now responsible for those events. ${ }^{92}$ In order to determine whether the Dalai Lama's regime had been recognised as a belligerent community, the following discussion first focuses on the legal nature of the recognition of belligerency and how it can be made.

\subsubsection{The Nature of the Recognition of Belligerency and the Way it is Made}

With regard to the nature of the recognition of belligerency, the opinions fall approximately into two schools. One school argues that the act of recognition is a concession of rights, privileges or legal status. ${ }^{93}$ As a result, a rebel group has no rights and no duties under international law until it is recognised. Although many writers of international law give more support to the concession theory, there is a very limited State practice in support of this concession theory. ${ }^{94}$ On the other hand, the other school

\footnotetext{
${ }^{91}$ Lindsay Moir, The Law of Internal Armed Conflict, Cambridge University Press, 2002, p 15.

${ }^{92}$ Hans Kelsen, Principles of international law, New York: Holt, Rinehart and Winston, 1966, pp 412-3.

${ }^{93}$ See note 29.

${ }^{94}$ Hall, W. E.: A Treatise on International Law, Oxford: Clarendon Press, 1924, p 36; Hershey, The Essentials of International Law and Organisation, New York: Macmillan, 1927, pp 115-9; Woolsey, Introduction to the Study of International Law, C. Scribner's sons, 1879, p 302; Lawrence, Principles of International Law, London: Macmillan, 1937, p. 328. With regard to the relevant State practice, see United States v. the Ambrose Light, 25 F. 408, District Court, Southern District of New York, September 30, 1885. The Ambrose Light, a vessel belonging to the insurgent party in rebellion against the Government of Colombia, was captured by an American gunboat in the Caribbean Sea. The vessel had instructions to attack Colombian ships and to engage in a hostile expedition against Cartagena, but
} 
argues that it is merely a declaration of a certain fact, that is, the existence of a civil war, and the rights and duties of belligerent flow from the fact of civil war. Therefore, recognition by the parent State or by a foreign State adds nothing to these rights and duties, nor does the refusal to recognise lessen them. ${ }^{95}$ The writers who hold the declaratory theory believe that recognition by the legitimate government or third States is an expression that they have acknowledged the existence of civil war and intend to accept rights and duties that may arise from this fact. When mentioning the conditions for recognition, Dana argues: '[I]t is certain that the state of things between the parent State and insurgents must amount, in fact, to a war, in the sense of international law, that is, powers and rights of war must be in actual exercise. ${ }^{96}$ It is obvious to him that recognition can only be granted after the belligerent status has been asserted by contesting parties. The declaratory theory also obtains the support of Calvo, who argued that the existence of civil war confers belligerent rights on the parties. ${ }^{97}$

Besides the opinions of jurists, numerous State practices have also demonstrated that recognition is merely a confirmation of the existence of war. For example, with regard to the US policy on the revolt of the Spanish colonies in America in 1822, President Monroe Stated: '[A]s soon as the (revolutionary) movement assumed such a steady and consistent form as to make the success of the provinces probable, the rights to which they were entitled by the law of nations, as equal parties to a civil war, were extended to them. Each party was permitted to enter our ports with its public and private ships. ${ }^{98}$ It can be inferred from the above Statement that the rights of insurgents as equal parties to civil war were derived from the operation of the law of nations and not through the concession of other States. The United States Supreme Court also adopted this view in the Case of the Santissima Trinidad. The Court affirmed that the existence of this civil war (between Spain and its colonies) gave both parties all the rights of war against each other. ${ }^{99}$ Similarly, in the Prize Cases, the Supreme Court reaffirmed that "what recognition does is not operate as a grant of rights of war, but create at the most a species

\footnotetext{
no other depredations were intended. The Court claimed: 'International Law has no place for rebellion; and insurgents have strictly no legal rights, as against other nations, until recognition of belligerent rights is accorded to them.'

${ }^{95}$ Ti-chiang Chen, p 333.

${ }^{96}$ Dana's edition of Wheaton, Elements of International Law, p 35, note 15.

${ }^{97}$ Carlos Calvo, Le Droit International Theorique et Pratique, vol. 4, 1896, p. 25. Recite from Ti-chiang Chen's Recognition, p 337.

${ }^{98}$ Specail Message to the Senate and House of Representatives of the United States, March 8, 1822. See The Addresses and Messages of the Presidents of the United States from Washington to Harrison, 1841, P 285.

${ }^{99}$ The Santissima Trinidad, 20 U.S. 283 (1822), see United States Reports, Cases Adjudged in the Supreme Court, Vol. 20, U.S. Government Printing Office, 1883, p 305.
} 
of estoppel. The neutral State estops itself from denying that a true war exists. ${ }^{100}$ In the case of Prats $v$ the United States, Prats, a Mexican citizen, claimed against the Government of the United States for the damages of cotton made by the Confederate forces, on the grounds that neither the American nor the Mexican Government had recognised the Confederate as a belligerent when the incident happened. The opinion of the United States-Mexican Mixed Claims Commission revealed that the following:

' $[\mathrm{N}]$ on-responsibility on the part of the United States for injuries by the Confederate enemy within the territories of that government to aliens did not result from the recognition of the belligerency of the rebel enemy by the strangers' sovereign. It resulted from the fact of belligerency itself, and whether recognised or not by other governments. But the proclaimed recognition of the fact by a government is conclusive evidence of the fact, and, so to speak, an estoppel as to that government., ${ }^{101}$

As for the practice of Great Britain, Lord Russell clarified the position of Britain in the American Civil War in a letter to Lord Lyons, saying, 'Her Majesty's Government admits that a civil war exists; they admit that whether the Confederate States of the South be sovereign and independent or not is the very point to be decided; but Her Majesty's Government affirms, as the United States affirmed in the case of the South American provinces, that the existence of this civil war gives both parties the rights of war against each other. ${ }^{\text {, }}{ }^{2}$

The above cases clearly illustrate that the rights of war and neutrality are derived from the existence of the war and not from the action of any State. The recognition of belligerency is the acknowledgement of a certain state of fact - the existence of war; it has the effect of evidence and estoppel, and is an expression of the intention of the recognising State to bring its future conduct into line with the requirements of the law in consequence of that fact. In this sense, the acquisition of the status of belligerents by insurgents is derived from the fact of civil war, from which flow the rights and duties of belligerents and neutrals. Recognition by the parent State or by a foreign State adds nothing to these rights and duties, nor does the refusal to recognise lessen them. In

\footnotetext{
${ }^{100}$ U.S. Supreme Court, the Prize Cases, 67 US (2 Black) 635 (1863), see https://www.loc.gov/item/usrep067635/.

${ }^{101}$ Case of Salvador Prats v. the United States of America, Mixed Commission established under the Convention concluded between the United States of America and Mexico on 4 July 1868. Reports of International Arbitral Awards (Volume XXIX) pp.187-202, see https://legal.un.org/riaa/cases/vol_XXIX/187-202.pdf.

${ }^{102}$ See dispatch of Lord John Russell to Lord Lyons, July 19, $1861 \mathrm{~m}$ in British and American Claims: British Claims No. 1 to 478 Memorials, Demurrers, Briefs, and Decisions, Issues 427-432, 1873, p 26.
} 
essence, the recognition of belligerency mainly serves as proof in determining whether the belligerent status of insurgents is confirmed by the parent State or third States.

Now that the recognition of belligerency can either be made by the legitimate government or third States when the existence of civil war is confirmed, the question arises as to how such recognition can be made. In general, there are two ways to recognise a belligerent: in an express way or in an implied one. For the sake of certainty, express recognition constitutes the strongest evidence of the existence of a belligerent. A proclamation of the recognition of belligerency or neutrality is usually considered as the most obvious express recognition. Furthermore, a declaration of blockade by the government of the parent State against insurgents can also be regarded as an express recognition of belligerency. However, express recognition is relatively rare in practice because in most cases the recognition is given implicitly. It is difficult to judge whether the recognition of belligerency has taken place when the government of the parent State, in the absence of an express proclamation, actually exercises the rights and duties in respect to hostility, or a third State chooses to confirm the exercising of such rights and duties. For this reason, the following acts that hint at the legal personality of the insurgents may be considered as evidence of recognition: the conclusion of agreements with the insurgents; ${ }^{103}$ the acknowledgement of official acts of the insurgents or their flag; the admission of insurgent ships into port and other semi-official intercourse with the insurgents. ${ }^{104}$ And most importantly, the Commercia belli, an agreement between belligerents on the treatment of activities that may affect the belligerents themselves or their populations during a civil war, may also strongly imply the existence of recognition. With regard to the effects of the Commercia belli, Rougier thinks that such acts may be considered to constitute recognition when they are performed in series and with the approval of the legitimate government. ${ }^{105}$ Compared with express recognition, implied recognition to some extent entails uncertainty, and the effects of implication are also decided by specific cases. ${ }^{106}$ Therefore, it is hard to distinguish a clear line between cases where such acts constitute recognition and where they do not.

\footnotetext{
${ }^{103} \mathrm{McNair}$ had stated that, although there was exceedingly little authority on the matter, there appeared to be no ground of principle which would prevent a neutral state from making agreements with the government of an insurgent community which it had community which it had recognized as belligerents. See Lord McNair, The Law of Treaties, Oxford: Clarendon Press, 1961, p. 680. The 1778 Franco-American Treaty of Alliance during the American Revolutionary War may be the rare example of such agreement, although France did not adopt a neutral position and recognized the America as a sovereign State directly.

${ }^{104}$ Ti-chiang Chen, pp 391-2.

${ }^{105}$ A. Rougier, Les Guerres Civiles et le Droit des Gens, 1903, pp 202-10, recite form Ti-chiang Chen, p 392.

${ }^{106}$ For example, the British Government denied that the conclusion of a commercial agreement with the Spanish Nationalists in February, 1937, constituted a recognition of their belligerency.
} 
It can be seen from the above discussion that although recognition confers no rights and duties on the insurgent in civil wars, it mainly plays an evidentiary role in judging whether the legitimate government and third States accept the fact that the insurgent has met the criteria of a belligerent. The following discussion explores whether the recognition of belligerency was ever accorded to the Dalai Lama's regime by either the Chinese Government or third States.

6.2.2 The Legal Nature of the Dalai Lama's Regime from the Perspective of Recognition of Belligerency

With regard to Sino-Tibetan armed conflicts from 1912 to 1951, a few States with geographic interests have directly or indirectly expressed their position on this matter. In order to maintain their interests in Tibet, Great Britain played an active role in the conflicts. In addition, the United States also began to express its opinion on SinoTibetan conflicts out of the need to unite China against Japan. Apart from those third States, the position of the Chinese Government obviously constitutes a decisive factor in judging whether the Dalai Lama's regime was a belligerent community in the hostilities. Therefore, the positions and conduct of the Chinese Government, Great Britain and the United States are examined to discover whether they constituted belligerent recognition of the Dalai Lama's regime. Furthermore, given that the Battle of Chamdo of 1950 attracted the attention of the member States of the UN General Assembly regarding regional peace, the opinions of the member States are also examined to demonstrate their views on the status of Tibet.

\subsubsection{The Position of the Chinese Government}

As mentioned in the previous section, both the Chinese and Tibetan armies had conducted hostilities in accordance with the requirement of laws of war during SinoTibetan armed conflicts. The captured soldiers of both parties were regarded as prisoners of war and treated in a humane way. More importantly, a series of truce agreements had been reached between the hostile parties. These truce agreements included many matters relating to hostilities, such as the beginning and ending time of 
the armistice, the exchange of prisoners of war and the delineation of the actual control line of both sides. Additionally, the protection of monasteries and the Buddhist religion and the maintenance of commercial and civil relationships between the Chinese and Tibetans were particularly stipulated in the Chamdo Truce of 1918 and the Gangtuo Truce of 1932. ${ }^{107}$ Given that both the Chinese Government and the Dalai Lama's regime had accepted the validity of these agreements, these agreements can be regarded as Commercia belli between the contesting parties. From the discussion in Section 6.1.3.2, it can be concluded that the rights and duties relating to the war stipulated in the Hague Regulations of 1907 and the Geneva Convention of 1949 had been mutually accorded between the Chinese and the Tibetan army. ${ }^{108}$ Moreover, considering that the Chinese army had concluded a series of truce agreements that amounted to Commercia belli from 1912 to 1951, it is reasonable to argue that the Chinese Government had implicitly recognised the Dalai Lama's regime as a belligerent during Sino-Tibetan armed wars.

As a result of this recognition, from the Chinese perspective, the Anglo-Tibetan treaties concluded in 1914 can also be regarded as agreements between the belligerent and the third State. ${ }^{109}$ In fact, there seems to be no established rule that would prevent a third State from making agreements with the government of an insurgent community that it had been recognised as a belligerent regarding the conduct of the civil war and matters arising out of it. ${ }^{110}$ For example, France concluded the Treaty of Alliance of 1778 with American insurgents during the American Revolutionary War. But such a case is exceedingly rare in State practice because it may damage the sovereignty of the parent State in civil war. For this reason, the content of such agreements is not unrestrained because a belligerent can only enter into agreements with a third State within the scope of its legal personality. Generally, such arrangements may involve the maintenance of commercial relations with a third State, the protection of their citizens in the territory

\footnotetext{
${ }^{107}$ The Article V of the Chamdo Truce stipulated: "It is agreed that the control of all the monasteries in the abovementioned Chinese governed districts, as well as the right of appointing high Lamas and other monastic functionaries, and the control of all matters appertaining to the Buddhist religion, shall be in the hands of the Dalai Lama; the Chinese authorities not interfering in any way therein; but the Lamas, on the other hand, shall not interfere in the territorial authority of the Chinese officials." And the Article IV of the Gantuo Truce stipulated: "From the date of the armistice and the withdrawal of troops, the traffic between the two sides will be restored, and there will be no hindrance between the merchants and the civilians only on the basis of the licenses issued by the official offices of both sides." See note $65 ; 74$.

${ }^{108}$ Article 4 to 20, 36 to 41 of the Hague Regulations respecting the Laws and Customs of War on Land of 1907; Article 33 of Geneva Convention relative to the Protection of Civilian Persons in Time of War, 1949; Article 13, 15, 118 of Geneva Convention Relative to the Treatment of Prisoners of War, 1949.

${ }^{109}$ During the Republican era, in the absence of Chinese participation, Tibet concluded three treaties with Great Britain in 1914: the Anglo-Tibetan Declaration, the Simla Convention, and the Anglo-Tibetan Trade Regulations.

${ }^{110}$ See Fitzmaurice, Third Report, in the Yearbook of the International Law Commission, Vol. II, 1958, p 32; Waldock, YILC, Vol. I, 1962, 639 $9^{\text {th }}$ Meeting, p 58.
} 
controlled by belligerents and the compensation of damage caused by belligerents, etc. On the other hand, those arrangements involving the disposal of important sovereign rights of the parent State, such as the demarcation of borders with a third State, can hardly be considered valid because of their uncertainty in the context of civil war. If the belligerent was eventually suppressed by the legitimate government, it is hard to expect that the latter would accept those arrangements that undermine the sovereign rights of the parent States, and this would inevitably lead to disputes between the parent State and the third States. With regard to the treaties concluded between Tibet and Britain in 1914, considering that the Dalai Lama's regime, as a belligerent, had the capacity to conclude agreements with any third State, these Anglo-Tibetan treaties can be treated as valid agreements before the demise of the belligerent status of the Dalai Lama's regime. However, it does not mean that all the provisions in these treaties are valid. For example, without the Chinese Government's consent, the articles relating to the division between Outer and Inner Tibet in the Simla Convention were not valid as long as Britain recognised the Chinese suzerainty over Tibet. For the same reason, the 'McMahon Line' marked on the map as an appendix to the Convention was also invalid because even if Tibet was under China's suzerainty, it was still part of China, and the right to delimit the border between Tibet and India should belong to the Chinese Central Government exclusively.

\subsubsection{The Position of Great Britain}

The British Government had expressed its position concerning Tibet during Yin Changheng's Tibet Expedition in 1912. According to Sir Jordan's memorial to the Chinese President Yuan Shih-kai, the British Government had formally recognised the suzerain rights of China in Tibet, but had never recognised, and were not prepared to recognise, the right of China to intervene in the internal administration of Tibet under Article I of the 1906 Anglo-Chinese Convention. ${ }^{111}$ Since then, Great Britain had consistently adopted this position until 1943 when they felt the need to withdraw this recognition. Fearing that the position might hinder the freedom of the British to enter into treaties directly with Tibetans, on 10 April 1943, the Foreign Office submitted a report called 'Tibet and the Question of Chinese Suzerainty' to the British Government

\footnotetext{
${ }^{111} \mathrm{FO} / 535 / 15$, Enclosure in no. 193.
} 
proposing to withdraw the recognition of Chinese suzerainty over Tibet for fully and effectively supporting Tibet's independence. ${ }^{112}$ The proposal was based on the following two factors: for one thing, Tibet had maintained its de facto independence for thirty years, that is, China had lost its effective authority over Tibet for thirty years; ${ }^{113}$ and for another, due to the refusal of China to sign the 1914 Simla Convention that confirmed the Chinese suzerainty over Tibet, Britain was free to decide on its Tibetan policy. ${ }^{114}$ In fact, the Chinese suzerainty over Tibet was first confirmed in the AngloRussian Convention of 1907, not the Simla Convention. Now that Britain was obliged to recognise the Chinese suzerainty when it participated in the Simla Conference in 1913, it was unlikely to regard Tibet as a sovereign State during the Conference. Then the question arises as to how to understand the 1914 Simla Convention between Britain and Tibet. Considering that the Simla Conference aimed to settle Sino-Tibetan conflict of 1912, did the 1914 Simla Convention constitute an implied recognition of belligerency of the Dalai Lama's regime by Britain? In fact, the affirmation of the insurgents' capacity to conclude agreements does not necessarily mean that the third power already recognised them as belligerents. During the Spanish Civil War, the British Government denied that the conclusion of a commercial agreement with the Spanish Nationalists in February 1937 constituted recognition of their belligerency. ${ }^{115}$ Thus, the conclusion of the Simla Convention alone did not mean that Britain had recognised the Dalai Lama's regime as belligerent. Other British responses to SinoTibetan conflicts should also be taken into consideration.

When the Second World War came to a crucial stage in the 1940s, the British Government had to reconsider its Tibet policy to avoid worsening alliances with China and the United States on the oriental battlefield of the anti-fascist war. On 23 July 1943, the British War Cabinet passed a resolution that British recognition of Chinese suzerainty over Tibet would be conditional on China's recognition of Tibet's full autonomy. ${ }^{116}$ It can be seen that the British took a step back from completely revoking the recognition of the Chinese suzerainty over Tibet; however, they would not recognise China's suzerainty over Tibet unconditionally. In the meantime, the British Government had provided the Dalai Lama's regime with many weapons and ammunition through

\footnotetext{
${ }^{112} \mathrm{FO} / 375 / 35755$, Tibet and the question of Chinese suzerainty, dated 10 April of 1943 .

${ }^{113}$ IOR/2252/43, Peel to H. Ashely Clarke, May of 1943.

${ }^{114}$ IOR/L/PS/12/41944, Foreign Office to Secretary of State for India, S. W. L, 29 April of 1943.

${ }^{115}$ H. A. Simth, Some Problems of the Spanish Civil War, British Year Book of International Law, 1937, p 28.

${ }^{116}$ IOR/W. P. (43)/275, War Cabinet, Status of Tibet, 23 July of 1943.
} 
India, and this action directly helped the Dalai Lama's regime to defeat the Chinese army in the second Sino-Tibetan armed conflict in 1917. It is hard to say whether the British Government adopted a neutral position during Sino-Tibetan conflicts because the activities of the British were inconsistent with the neutral obligation of third States derived from the recognition of belligerency. ${ }^{117}$ Therefore, little clear evidence can be found from the position of Britain that it intended to treat the Dalai Lama's regime as a belligerent community.

\subsubsection{The Position of the United States}

As the United States have had no special interests in Tibet in modern times and China was its ally during the Second World War, it had adopted a non-interference policy on the Tibet issue until the Nationalist Government was overthrown in 1949. In 1942, the deteriorating military tension between the Nationalist Government and the Dalai Lama's regime was heightened over the transport of goods through Tibet for resistance against the Japanese fascists. Fearing that the Chinese army might take military action against the Tibetans, the British Foreign Office tried to seek the US Secretary of State Hull's help in putting pressure on China. In response to the British inquiry about the US attitude towards Tibet's independence, Hull asked the American ambassador Gauss to discreetly inquire into the situation and noted that 'it is not clear whether the words "independence" and "autonomy" are used interchangeably or not', ${ }^{118}$ because he had hoped to avoid any misunderstanding on the US position on the status of Tibet. In response to the Tibetans' request to buy radio transmitters from the United States, George Atcheson, the assistant chief of the Division of Far Eastern Affairs in the Department of State, expressed that any positive reaction by the US to the Tibetans would be politically embarrassing and cause irritation and offence to the Chinese. ${ }^{119}$ After receiving the news that the Chinese army had assembled on the border of Tibet in

\footnotetext{
${ }^{117}$ However, during the American Civil War, Great Britian had explicitly recognized the Confederate States as belligerency through a declaration of neutrality. At the same time, Britain failed to stop the British shipyards from building warships for the Confederate States and delivering them to the latter. See the Alabama Claims, concerning the rights of the United States following Great Britain's failure to act as neutrality demanded during the American Civil War, in Moore, History and Digest of Arbitrations, 495 at 653.

${ }^{118}$ FRUS China 1942, Memorandum from the Secretary of State to the Ambassador in China, dated 3 July of 1942, p 626.

${ }^{119}$ Atcheson wrote that "the Chinese Government claims suzerainty over Tibet. Therefore, in all possibility, the Chinese Government would not welcome the introduction into Tibet of such a potent facility as a radio transmitter, particularly as the Chinese are not likely to have any actual control over the transmitter or the broadcasted." See Memorandum by the assistant chief of the Division of Far Eastern Affairs (Atcheson), 30 March, 1943, pp 624-5.
} 
1943, Hull, the Secretary of State, requested the chargé d'affaires in China to obtain information related to the situation mentioned above but hoped that he would not make any comments on this issue publicly. ${ }^{120}$ Furthermore, in order to stop the deteriorating military tensions between the Chinese and the Tibetans, the US General Stilwell and other allied commanders were determined that hostilities between China and Tibet should be avoided at all costs. ${ }^{121}$ On 15 May 1943, the US Government again proclaimed their position on Tibet: '[T]he Government of the United States has borne in mind the fact that the Chinese Government has long claimed suzerainty over Tibet and that the Chinese constitution lists Tibet among areas constituting the territory of the Republic of China. This Government has at no time raised a question regarding either of these claims.' ${ }^{122}$ After the Second World War, the Dalai Lama's regime sent a business delegation to the United States. The State Department immediately informed the Chinese Embassy of the matter and invited the Chinese ambassador to discuss President Truman's meeting with Tibetan representatives. The Chinese Foreign Ministry asked Truman not to meet with the Tibetan business delegation, but the United States was not willing to hurt the feelings of the Tibetan delegation, which put the US Government in a difficult situation. Therefore, the US Government decided to exert pressure on China. In a meeting with the Chinese minister, the Department of State emphasized that although the United States had 'no intention of acting in a manner to call into question China's de jure sovereignty over Tibet', the Chinese should also 'appreciate that the fact that it exerts no de facto authority over Tibet is the root cause of the situation'. ${ }^{123}$ This Statement by the US State Department had clearly shown the United States' position on Tibet, which recognised that Tibet was a part of China, but also acknowledged that the National Government could not actually control Tibet. It implied that the US affirmed that the Dalai Lama's regime was the de facto authority in Tibet, although Tibet was still a part of China. It can be inferred from the cautious position of US diplomats and Stilwell's Statement that the United States generally adopted a policy of non-intervention regarding Sino-Tibetan hostilities, although this non-interference policy was somewhat ambiguous rather than neutrality. For this reason,

\footnotetext{
${ }^{120}$ Recite from Wu Jingping (吴景平), Selected Translations of Historical Documents in the U.S. Diplomatic Archives Concerning the Negotiations between China, America and Britain on the Tibet Issue (美国外交档案中有 关中美英三国交涉西藏问题的史料选译), Journal of Anti-Japanese War Research (抗日战争研究), 1994, Vol.3, p 164.

${ }^{121}$ Lezlee Brown Halper, Stefan A. Halper, Tibet: An Unfinished Story, Oxford University Press, 2014, p 30.

${ }^{122}$ FO/371/135756, aide-memoire sent by the U.S. Department of State to the British Embassy in Washington, D.C., dated 15 May 1943.

${ }^{123}$ USFR, 693.0031 Tibet/7-2648, Memorandum of Conversation of J. F. Melby, second secretary, U.S. Embassy in China, with George Yeh, Vice-minister of Foreign Affairs, dated 26 July of 1948.
} 
it cannot be rashly assumed that the United States had recognised the Dalai Lama's regime as belligerent at this stage. However, from the Department of State's statement that the Dalai Lama's regime was the de facto authority over Tibet, the United States might have indicated that Tibet was a de facto State at that time.

6.2.2.4 The Position of Member States in the UN General Assembly Regarding the Battle of Chamdo

After the fall of Chamdo in 1950, the Dalai Lama's regime submitted an appeal to the Secretary-General of the United Nations on 7 November 1950. In this appeal, the Dalai Lama Stated: '[T]he armed invasion of Tibet for the incorporation of Tibet in Communist China through sheer physical force is a clear case of aggression. As long as the people of Tibet are compelled by force to become a part of China against their will and consent, the present invasion of Tibet will be the grossest instance of the violation of the weak by the strong. We therefore appeal through you to the nations of the world to intercede on our behalf and restrain Chinese aggression.' ${ }^{124}$

Because Tibet was not a member of the UN, the UN Secretariat only informally copied the appeal to delegations of the Security Council and said the appeal would not be issued as a Security Council document unless a member of the UN asked for it to be placed on the Council's agenda. ${ }^{125}$ On 14 November, the delegation of El Salvador asked the Secretary-General to bring the appeal before the General Assembly. However, the Secretariat decided to put the appeal before the General Committee for a discussion on whether it should be referred to the General Assembly. ${ }^{126}$ By this time, India had become independent of Britain's rule. The Indian Government regarded the promotion of Sino-Indian cooperation as their priority foreign policy. Meanwhile, it also hoped to inherit all British rights and interests in Tibet. So the Tibet issue obviously became a stumbling block to this policy. As regards the Tibetans' appeal, India was reluctant to support China's sovereign claim over Tibet openly. Instead, they expected that the Chinese Central Government and the Dalai Lama's regime would continue the peaceful negotiation. Thus, the Indian delegate advocated that the United Nations should

\footnotetext{
${ }^{124} \mathrm{FO} / 371 / 184454$, telegram from the United Kingdom's U.N. delegation to the British Foreign Office, dated 14 November of 1950

${ }^{125}$ Ibid, dated 13 November 1950.

${ }^{126}$ United Nations Document A/1534.
} 
abandon the discussion on Tibet because the Chinese army had stopped their advance to Lhasa after the Battle of Chamdo. The Indian Government was sure that the question could be settled by peaceful means, and such a settlement could safeguard the autonomy that Tibet had enjoyed for several decades while maintaining its historical association with China. ${ }^{127}$ The Indian Government obviously did not want to intervene in the armed conflicts between the Chinese and the Tibetans. Therefore, it adopted a neutral position on this matter. In the meantime, the expression of "autonomy of Tibet for several decades" also indicated that India admitted that Tibet was in a State of de facto independence. In this sense, the speech of the Indian delegate in the GA was roughly equivalent to a proclamation of neutrality. Unlike Great Britain, the Indian Government did not provide any military support to the Tibetans after inheriting British interests in Tibet. In the meantime, as the successor of Britain, India claimed that the treaties concluded between Britain and Tibet during the Republican era were valid, and India should become the undertaker of these treaties. ${ }^{128}$ Now that India had confirmed the capacity of the Dalai Lama's regime to enter into treaties with third States and believed that India had become a party to these treaties, it is reasonable to argue that the treaty-making capacity of the Dalai Lama's regime was admitted by India, which may be considered as evidence of the recognition of belligerency.

As for the position of Great Britain, because the British had already handed over their rights and obligations on Tibet to India without reservation, the opinion of the Indian delegate undoubtedly played a crucial role in affecting the view of Britain. The British delegation preferred to avoid debate on the Tibetan issue on the grounds that the Committee did not know what was happening in Tibet, and the legal position of Tibet was not very clear. Moreover, it could still be hoped that the existing difficulties in Tibet could be settled amicably by agreement between the parties concerned. ${ }^{129}$ After the Indian delegate's speech, all the other countries fell into line. The Australian representative agreed with the opinions of India and Great Britain. The representative of the Soviet Union also supported abandoning the discussion on Tibet, but for a different reason. For the Soviet Union, 'Tibet was an inalienable part of China, and its affairs were the exclusive concern of the Chinese Government. Chinese sovereignty over Tibet had been recognised for a long time by the United Kingdom, the United

\footnotetext{
${ }^{127}$ Melvyn C. Goldstein, pp 734-5.

${ }^{128}$ These treaties refer to Anglo-Tibetan Declaration of 1914; the Simla Convention between Britain and Tibet of 1914; and Anglo-Tibetan Trade Regulations of 1914.

${ }^{129}$ Melvyn C. Goldstein, pp 734-5.
} 
States and the USSR. The question was, therefore, one that came essentially within the national jurisdiction of China; the United Nations could not consider it. If it did so, it would be guilty of unwarranted intervention in the internal affairs of the Chinese people.' ${ }^{130}$ Although there was no unanimous position adopted by the General Assembly on the Battle of Chamdo, the opinions of the above States revealed that they were more willing to create an impression of non-interference in Sino-Tibetan conflict of 1950. Therefore, apart from India, it is hard to say that other States had the intention to recognise the Dalai Lama's regime as a belligerent.

From the above discussion, it can be seen that although there was little express belligerent recognition of the Dalai Lama's regime, the acts of the Chinese army clearly demonstrated that the Chinese Government had treated its opponent as a belligerent rather than common criminals or rebels, and such recognition was made in an implicit way. Compared with the recognition made by third States, the international legal personality of insurgent groups that are recognised as belligerents by the parent State is more far-reaching than that of those groups recognised by third States, because when an insurgent group is recognised as a belligerent by the parent State, it gains a status vis-à-vis the international community as a whole. In contrast, when a third State recognises an insurgent group as a belligerent, it only reveals that the third States accept the consequence that the laws of war become applicable between the belligerent and itself. ${ }^{131}$ From this perspective, the Chinese Government's action was more convincing than that of other third States in manifesting the belligerent status of the Dalai Lama's regime. However, given that the Chinese Government consistently claimed its full sovereignty over Tibet, it was unlikely to recognise Tibet as a de facto State through its belligerent recognition. In contrast, the United States' Statements in the 1940s and India in 1950 seem to indicate that they were more willing to regard Tibet as a de facto State.

\section{Conclusion}

After the fall of the Qing Dynasty, the Dalai Lama's regime had cut off the connection with the Chinese Government and maintained its status as a de facto State from 1911

\footnotetext{
${ }^{130}$ Ibid, pp 735-6.

${ }^{131}$ Katharine Fortin, The Accountability of Armed Groups under Human Rights Law, Oxford University Press, 2017, p 98.
} 
to 1951. As a concept describing unrecognised State-like entities, the notion of a de facto State in itself is not the subject of international law. However, it does not prevent its organised political leadership from obtaining such a status under certain conditions. For this reason, this chapter explores whether the Dalai Lama's regime - the element that constituted Tibet's de facto State status - possessed any status in international law. Considering that a series of armed conflicts happened between the Tibetan and Chinese armies from 1912 to 1951, the laws governing domestic strife during the first half of the twentieth century - belligerence and its recognition - can serve as a constructive perspective on this issue. More specifically, this chapter answers the question as to whether the Dalai Lama's regime met the criteria of a belligerent in the context of SinoTibetan conflicts and whether the recognition of belligerency had ever been granted to this regime either by the Chinese Government or any third States.

Through analysing the relevant historical facts, the following conclusions can be drawn. First, the scale and intensity of the armed conflicts between the Chinese army and the Tibetan army did amount to civil war in an international legal sense. In other words, the Dalai Lama's regime and the Chinese Government were in a State of civil war. Besides, each of the hostile parties had fundamentally followed the rules of war. In this sense, the rights and duties relating to the armed conflict were entitled to the Dalai Lama's regime. Second, the whole territory of central Tibet and part of Kham were under the control of the Dalai Lama's regime. Third, this regime, in fact, functioned as a civil government and exercised supreme authority over the above territories. Fourth, given that the goal of the regime was to achieve the de jure independence of Tibet, their hostile acts against the Chinese army were political. Based on the above analysis, it can be concluded that the Dalai Lama's regime during the Republican period was in accordance with the criteria of a belligerent in international law. With regard to the recognition of the belligerency of the Dalai Lama's regime, although little evidence can be found that the regime was recognised either by the Chinese Government or by other third States expressly, the behaviour of the Chinese army had to some extent implicitly revealed that the Chinese Government had treated this regime as a belligerent. Following this point of view, the Anglo-Tibetan treaties concluded in 1914 can be seen as agreements between the belligerent and the third States. In this sense, they were valid in principle. But this does not mean that all the provisions in these treaties were valid. Apart from the position of the Chinese Government, the neutral attitude of India in 1950 also to some extent implied that it might treat the regime as a belligerent. On the 
question of whether such recognition could constitute the recognition of Tibet as a de facto State, given that the Chinese Government had consistently claimed its full sovereignty over Tibet, it was unlikely to recognise Tibet as a de facto State. On the other hand, the positions adopted by the United States in the 1940s and India in 1950 seem to indicate their acceptance of the status of Tibet as a de facto State. 


\section{Chapter 7 Conclusions}

\section{Introduction}

This concluding chapter provides an overall response to the research question of this thesis through a discussion of the previous chapters. As mentioned in Chapter 1, the core question of this $\mathrm{PhD}$ research is: How to understand Tibet's status from the $1840 \mathrm{~s}$ to the 1950s in the sense of international law? Exploring this general question more comprehensively entails asking the following subquestions:

(1) Before Western international law was introduced to China in the $1840 \mathrm{~s}$, what status did Tibet possess under the traditional Chinese tribute system?

(2) After knowing the traditional Sino-Tibetan relations before the $1840 \mathrm{~s}$, how to understand the development of Tibet's status from the Opium War in 1840 to the end of the Qing Dynasty in 1911 under the unequal treaty system?

(a) How did the Tibet-related treaties concluded between the Qing Governments and the Western States reflect the status of Tibet?

(b) Was 'suzerainty' an appropriate term to define the Sino-Tibetan relations before the collapse of the Qing Dynasty in 1911?

(3) What status did Tibet possess from the establishment of the Republic of China in 1912 to the restoration of Tibet by the Chinese in 1951 ?

(a) Was Tibet an independent sovereign State in international law during this period? If not, what status did it have from the perspective of international law?

(b) In addition to focusing on Tibet's status from the perspective of its Statehood, is it possible that the ruling regime on this land, namely the Dalai Lama's regime, enjoyed some status in international law in the context of the Sino-Tibetan armed conflicts during this period?

To answer the above questions, a series of key findings are presented in Section 7.1, and based thereupon, a general conclusion is drawn to respond to the main research 
question of this thesis. In addition, Section 7.2 discusses the relevance of this research at an academic and practical level and identifies possible future research areas.

\subsection{Key Findings of the Research and Answers to the Research Question}

As the main aim of this research is to ascertain the status of Tibet since the 1840 s, and in order to understand the whole picture, it is necessary to study Tibet's status under the traditional Sino-Tibetan relations before this period. On the basis of knowing the development of Tibet's status from the Tang Dynasty (618-907 AD) to the late Qing Dynasty (prior to the 1840s), this section then focuses on the influence of Western Powers' encroachment on the status of Tibet from the perspective of international law. It first examines the Tibet-related treaties that reflected the positions of the Qing and the third States on Tibet's status before the fall of the Qing in 1911. Then this section also answers the question as to whether Tibet became an independent sovereign State during the period of the Republic of China (approximately from 1912 to 1951), and if not, what status did it possess in international law? And apart from emphasising the Statehood, this section also discusses the possibility that the ruling authority on this land, namely the Dalai Lama's regime, became a subject of international law in the context of the Sino-Tibetan armed conflicts during this period.

\subsubsection{The Status of Tibet Under the Framework of the Tribute System}

For a long time, the history of international law was Eurocentric, which excluded some non-European regions that developed a set of rules or practices enabling the members of that region to interact with each other. In this sense, a truly "universal" history of international law should include the forms of regional international law that emerged in the non-European areas, such as ancient China and ancient South Asia. Ancient China developed a hierarchical and Sinocentric system that embodied a set of rules and diplomatic norms to deal with its surrounding countries. This system is called the 'tribute system'. As a legal framework for ancient China to manage its external relations, the tribute system is the fundamental institution that embodies both philosophical assumptions and institutional practices that shape relations between China and other participants based on Chinese superiority. However, the relevant historical facts 
revealed that the tributary (which usually refers to the surrounding countries and ethnic minorities) and the recipient of tribute (which usually refers to imperial China) were not always static and could be inverted due to the rise and fall of the empire's strength in some periods. This indicates that the tribute system was a dynamic and flexible mechanism. ${ }^{1}$ Generally speaking, there are four main institutions to govern rights and obligations of peace and war between China and the surrounding non-Chinese people, especially ethnic minority regimes, namely Cefeng (册封), Hushi (互市), Huimeng (会 盟) and Heqin (和亲). ${ }^{2}$ Cefeng refers to the historical phenomenon when the rulers of tribes and surrounding countries showed their willingness to submit to the Chinese emperor, and in return, the emperor conferred on the rulers noble titles to manifest the legitimacy of their rule. Hushi, as a kind of mutual trade, refers to the surrounding countries and ethnic tribes selling local specialities to China in border areas or on their way of paying tribute. Huimeng, which was similar to a peace conference in modern times, was often aimed at declaring the end of a war, demarcating the boundaries and forming a military alliance. Heqin refers to the practice of the Chinese emperor of betrothing his daughter to the ruler of an ethnic minority regime, and it was often adopted as an appeasement strategy to deal with the surrounding ethnic regimes that were too strong to defeat on the battlefield. In comparison with Cefeng and Hushi, Huimeng and Heqin usually happened when the imperial court lacked an absolute advantage over the surrounding power, and therefore both parties interacted on a relatively equal basis. The above four institutions constituted the main form of the SinoTibetan interactions before the 1840s.

With regard to how the tribute system affected ancient China's view on its boundaries, it should be understood that the boundaries between the imperial court and the surrounding ethnic minority regimes constantly changed according to the comparison of their strength. When the imperial court was too weak to exert influence over the ethnic minority regimes, it was inclined to recognise the latter's independence. In contrast, when the imperial court was powerful and interested in expanding the influence on these regimes, it was inclined to bring them into different levels of governance. For those minority regimes that submitted to the imperial court, they were generally divided into Wai Fan (外藩, external tributary) and Nei Fan (内藩, internal tributary) according to whether the imperial court could influence the internal

\footnotetext{
${ }^{1}$ See Chapter 2, Section 2.1,1.

${ }^{2}$ See Chapter 2, Section 2.1.2.
} 
administration of these regimes. ${ }^{3}$ In contrast to an internal tributary, an external tributary often refers to a regime that maintained its independence over its internal affairs, whereas in the case of an internal tributary, under the premise of not changing the original governance model of these regions, the imperial court usually despatched the term-limited officials to collaborate with the native chieftains in local administrations and eventually replaced these chieftains. Thus, the imperial court extended its boundaries to the internal tributaries seeing that these ethnic minority regimes could neither control their external affairs nor independently handle their internal affairs.

It was under the above institutional framework that the traditional Sino-Tibetan relations developed from the Tang Dynasty to the late Qing Dynasty. In regard to the Sino-Tibetan relations in the Tang Dynasty, the interactions between the Tang court and the Tibetan Empire (Tubo, 吐蕃), established by Song-tsen Gam-po in the early seventh century, mainly included Huimeng and Heqin. ${ }^{4}$ As the eastward expansion of Tubo posed a significant threat to the Tang court, the latter had to adopt the institution of Huimeng to quell border conflicts. Like a peace conference in the modern sense, Huimeng usually took place when the war between the Tang and Tubo was temporarily over, and the representatives of both parties declared a truce to rebuild their friendship and redefine the boundaries. As well as Huimeng, the institution of Heqin was also adopted by the emperor to ease the confrontation with Tubo. Two matrimonial alliances occurred during the Tang Dynasty. As previously mentioned, the institutions of Huimeng and Heqin were often used to relieve the threat to the imperial court when the surrounding countries and ethnic minority regimes were approximately equal to, or stronger than, imperial China. In the relations between the Tang and Tubo, neither Huimeng nor Heqin had formed a political dependency between them. On the contrary, Tubo not only independently dealt with its internal and external affairs but also posed a great threat to the survival of the Tang. Therefore, as the Tibetans did not recognise the superiority of the Chinese emperor and governed all affairs at their will, Tubo should be considered as an independent country in relation to the Tang.

The Tibetan Empire collapsed and was split into different tribes after its last ruler was assassinated in 842 . This fragmented situation lasted throughout the Song Dynasty

\footnotetext{
${ }^{3}$ See Chapter 2, Section 2.1.3.

${ }^{4}$ See Chapter 2, Section 2.2.1.
} 
(960-1279) until the arrival of the Mongols in the thirteenth century. Although the unified Tibetan Empire no longer existed, these Tibetan tribes were still able to handle their affairs independently. In the meantime, the Song court maintained only limited contact with some eastern Tibetan tribes and did not intend to bring these tribes under its control. In this sense, the Tibetans who existed in tribes were independent of imperial China during the Song Dynasty. However, the conquest of Tibet by Mongols and the establishment of the Yuan Dynasty (1271-1368) in China proper profoundly influenced Sino-Tibetan relations. ${ }^{5}$ In fact, the submission of the Tibetans to the Mongols can be traced back to 1247 when the Tibetan religious hierarch Sakya Pandita, on behalf of the Tibetans, submitted to the Mongolian prince Godan. After that, a relationship known as 'patron-priest' was established between the Mongols and the Tibetans. After Kublai established the Yuan Dynasty, Emperor Kublai set up Zongzhi Yuan (the Bureau of Buddhist and Tibetan Affairs) to supervise Buddhist affairs and the administration of Tibet. He then appointed Phagpa, Sakya Pandita's nephew, as the chief of the Zongzhi Yuan and the emperor's preceptor. Later, Phagpa returned to Tibet, establishing a Sakya regime to deal with Tibetan affairs. The Sakya regime gradually became the actual ruler of Tibet outside the Yuan court's direct control, although its influence did not reach the whole of Tibet. As the chief of the Zongzhi Yuan and the head of the Sakya regime, the imperial preceptor not only needed to maintain his influence in Tibet through the Sakya regime but also needed the support of the emperors to ensure the Sakya regime's dominant position in Tibet. For the emperors, despite the fact that they did not transform Tibet into a province but kept it under the jurisdiction of Zongzhi Yuan, they could indirectly exert their influence on the Tibetans through appointing the imperial preceptor. Moreover, given that the Tibetans had already submitted to the Mongols before the establishment of the Yuan Dynasty, the control of Tibet's external affairs such as military affairs and the alliance was naturally inherited by the Yuan emperors. In this sense, Tibet had turned into an external tributary of the Yuan court. As for the "patronpriest' relationship between the emperor and the Tibetan lama, it could not be only a religious and personal relationship in which the lama provided the emperor with spiritual guidance, and the emperor, in turn, was responsible for protecting and promoting the interests of the lama. As both the emperor and the lama were political figures, and their relationship was also a political one based on inequality. In the religious aspect, the emperor could regard the lama as his teacher, but in the political aspect, the lama could never consider himself another monarch equal to the emperor.

\footnotetext{
${ }^{5}$ See Chapter 2, Section 2.2.2.
} 
In 1358, the Sakya regime was replaced by the Phamo-drupa regime, which subsequently ruled U-Tsang (Central Tibet) for a century. Soon afterwards, the Yuan Dynasty was also overthrown and replaced by the Ming Dynasty (1368-1644) in China proper. To persuade the Tibetans to give up allegiance to the Mongols, the emperors of the Ming Dynasty bestowed the new title to the ruler of the Phamo-drupa regime. But compared with the Yuan court, the Ming court only had a weak influence in central Tibet. In eastern Tibet, the Ming court set many garrisons called Weisuo (卫所) to defend its north-western borders from the Mongols' harassment. ${ }^{6}$ In fact, a Weisuo was not only a military station but also an administrative unit in eastern Tibet. The Ming court appointed term-limited Han officials as the head of the Weisuo to govern the administration of eastern Tibet. In the meantime, the local chieftains were also appointed as high officials to assist the Han officials, and their descendants could inherit their imperial posts. In accordance with the different degree of the Ming influence on the Tibetans, Tibet could be generally divided into two geographical regions during the Ming Dynasty: one was eastern Tibet under the rule of the Weisuo set by the Ming court. Through applying the institution of Cefeng, the local chieftains who accepted imperial posts showed their submission to the emperor of the Ming. On the other hand, the despatching of Han officials to participate in the civil and military affairs of the Weisuo indicates that the Ming court had already intervened in the internal affairs of eastern Tibet. Therefore, this region formed an internal tributary of the Ming Dynasty, whereas in central Tibet, although the Phamo-drupa regime accepted the symbolic and ceremonial title of the Ming court, it could independently govern all affairs in this region because the Ming's influence in this region was far less than that of the Yuan Dynasty. For this reason, central Tibet should be considered an independent region throughout the Ming Dynasty.

With the rise of the Manchu, an ethnic group that lived in the north-east of the Ming, they terminated the Ming Dynasty and formally established the rule of the Qing Dynasty in 1644. With respect to Tibet, among other Buddhist sects, the Geluk sect led by the Dalai Lama appeared in the early fifteenth century. With the help of the Khoshut Mongol, the fifth Dalai Lama established the Ganden Phodrang regime and became the supreme secular and religious leader in Tibet in 1642. Although the fifth Dalai Lama visited the Qing Emperor Shunzhi in Beijing in 1652, this first official contact did not

\footnotetext{
${ }^{6}$ See Chapter 2, Section 2.2.3.
} 
form any formal relations between Tibet and the Qing. The Qing's first interference in Tibetan affairs took place after the death of the fifth Dalai Lama, and Emperor Kangxi despatched the first Manchu commissioner to Lhasa to assist Lhabsang, the ruler of the time, in dealing with Tibetan affairs. Subsequently, in response to the invasion of Tibet by Dzungar Mongols, Emperor Kangxi despatched the Qing army to Lhasa to expel the Dzungars from Tibet and placed the seventh Dalai Lama on the throne of Tibet. ${ }^{7}$ To further stabilise the political situation in Tibet, Emperor Yongzheng despatched two imperial residents known as ambans to Lhasa to report the events of Tibet to him in 1728. In the reign of the Emperor Qianlong, he despatched an army to suppress the turmoil in Lhasa and issued a decree to reorganise the Tibetan political system. According to this decree, the power of ambans was increased, and they could participate in Tibetan affairs to a certain extent. At this point, the power of Tibetans to deal freely with Tibetan affairs began to be interfered with by the Qing court. However, given that the ambans were involved in the administration of Tibet to a limited extent, Tibet had become an external tributary of the Qing at this stage. After the Qing's army defeated the Gurkhas' invasion of Tibet in 1792, Emperor Qianlong issued another decree called 'Twenty-Nine Regulations for Better Government in Tibet', which fundamentally altered the Qing's previous Tibetan policy. The status of ambans was unprecedentedly enhanced, achieving equal status with the Dalai Lama in the political field. Ambans were formally authorised to participate in the administration of Tibet, and all Tibetan lay officials and clerical staff had to submit all crucial issues to ambans for a decision. Moreover, ambans were also in charge of the defence of the frontier, the administration of the finances and the foreign intercourse of Tibet. The establishment of the supreme authority of ambans marked the moment that the Qing court formally abolished the independence that Tibet had enjoyed for a long time. ${ }^{8}$ It can be seen from the 1793 imperial decree that not only had the power of the ambans been increased to the same status as the Dalai Lama and the Panchen Lama but they had also been given the final decision-making power on Tibet's internal and external affairs, which indicates that the Qing court had formally abolished the independence that Tibet had enjoyed for a long time. The 1793 decree meant that for the first time in Sino-Tibetan history, the Chinese emperor claimed imperial China's direct control over Tibet in the form of law. After that, Tibet became an internal tributary within the territory of the Qing Empire.

\footnotetext{
${ }^{7}$ See Chapter 2, Section 2.3.2.

${ }^{8}$ See Chapter 2, Section 2.3.3.
} 


\subsubsection{The Status of Tibet at the End of the Nineteenth Century}

In the 1840s, the Qing's failure in the Opium War forced China to learn about modern international relations and international law. By concluding many unequal and nonreciprocal treaties with Western powers, the Qing fell into an unequal treaty system dominated by Western powers. ${ }^{9}$ Unlike the principle of sovereign equality pursued among Western powers, many Sino-Western treaties were not only concluded under the coercion of armed force but also gave Western powers unilateral privileges in many fields. ${ }^{10}$ This unequal treaty system was by its nature a privilege of 'quasi-sovereignty' exercised by Western powers over China. However, China did not lack the initiative to learn and apply international law in its foreign relations. The Qing court began to translate and study Henry Wheaton's Elements of International Law as the first step to securing its national interests. In addition, the Tsungli Yamen, the first diplomatic department in Chinese history, was also established by the Qing court for the convenience of dealing with Western powers. ${ }^{11}$ By applying international law, the Qing Government successfully requested Prussia to compensate for its illegal acts in China's internal waters in 1864 and signed a commercial treaty with Peru to protect the interests of Chinese labourers in Peru in $1874 .{ }^{12}$ Although the unequal treaty system had significantly impaired China's sovereignty and interests since the 1840s on the one hand, on the other hand, China had safeguarded its interests to a certain extent by studying and utilising international law. More importantly, as the traditional tribute system began to collapse in the face of Western encroachment, the Qing's acceptance and application of modern international law provided a different lens to observe the status of Tibet under this legal framework, especially considering that Great Britain and Russia had got involved deeply in Tibetan affairs in the second half of the nineteenth century.

As a product of the unequal treaty system, the Qing concluded a series of Tibet-related treaties with the Western Powers. Seeing that these treaties might, to some extent, reveal the development of Tibet's status during this period, it is necessary to first clarify the validity of unequal treaties. According to the international law of the nineteenth century, a treaty was only valid if made between the subjects of international law, which were

\footnotetext{
${ }^{9}$ See Chapter 3, Section 3.1.1.

${ }^{10}$ For example, extraterritorial jurisdiction, one-sided most-favoured-nation treatment, leased territories, foreign troops station and navigation rights on coastal and inland waters.

${ }^{11}$ See Chapter 3, Section 3.1.1.

${ }^{12}$ Ibid.
} 
'civilised' States. However, not all political entities could amount to a State, and a 'civilised' State was a higher standard. Based on the opinion of the Institut de Droit International in 1879, China could hardly be excluded from the community of civilisation, and therefore its eligibility for making treaties with the European States had to be affirmed. ${ }^{13}$ As for the validity of unequal treaties that were concluded by use of force or coercion against a State, legal scholars of the nineteenth century generally upheld the idea that only the coercion of representatives of a State would constitute a justification for the invalidity of a treaty. Thus, the unequal treaties might not necessarily be invalid unless the representatives of that State were subjected to force or coercion during the negotiation. From the perspective of that time, those Tibet-related treaties that were concluded between the Qing and the Western Powers before the 1911 Chinese Revolution were valid under international law.

In the second half of the twentieth century, three Tibet-related treaties were concluded between China and Great Britain: the Separate Article in the Chefoo Convention of 1876, the Convention Relating Burma and Tibet of 1886 and the Convention Between Great Britain and China Relating to Sikkim and Tibet of 1890.

According to the Chefoo Convention of 1876, the British obtained the right to send a mission from the interior of China to Lhasa, the Zongli Yamen was required to issue the necessary passports to the mission and the ambans in Lhasa would send officers to take care of the mission if they entered Tibet from the Indian frontier. ${ }^{14}$ Although the Chefoo Convention did not explicitly mention the status of Tibet in its provisions, the British request to issue passports to some extent reflected Britain's position on Sino-Tibetan relations. Passports are official documents issued by national authorities of the bearer to offer some proof of identity and nationality and enable the crossing of international boundaries. Under some circumstances, a government can also issue passports to foreigners to allow the latter to enter some regions of the State. This is the case with the Chefoo Convention. The conclusion of the convention indicated that the British believed that Tibet was under the jurisdiction of the Qing Government, and the latter possessed the authority to make treaties on Tibet's behalf. Furthermore, the British requirement concerning the ambans' duty is also indicative of the British opinion that the ambans were the actual governors of Tibet. In the Convention Relating to Burma

\footnotetext{
${ }^{13}$ Travers Twiss, 'Rapport', 3-4 Annuaire Institut de Droit International (1879-1880) pp. 301-05. See Chapter 3, Section 3.1.2.

${ }^{14}$ See Chapter 3, Section 3.2.2.
} 
and Tibet of 1886, the British Government confirmed that it was the Qing Government's duty to adopt measures to arrange the frontier trade between India and Tibet, and the Qing Government was asked to encourage the Tibetans to promote the trade. ${ }^{15}$ The treaty provisions left the British with no excuse to contact Tibet in the absence of the Qing's participation. By implying that Tibet was part of the Qing Empire, the Chefoo Convention and the Convention Relating Burma and Tibet in fact denied any independent status of Tibet. In addition, the Convention Between Great Britain and China Relating to Sikkim and Tibet of 1890 further indicated the Qing's sovereignty over Tibet. ${ }^{16}$ According to Article I of the Convention, the boundary between Sikkim and Tibet was demarcated by the British Government and the Qing Government. As boundaries determine the scope of the State's territory and the exercise of sovereignty, the right of demarcation should only be attributed to sovereign States alone, and these States should have a direct concern over the disputed territory. Given that Article I of the 1890 convention delimited the boundary of Sikkim and Tibet, it suggested that the two high contracting parties had already reached a consensus that Sikkim was under the sovereignty of Britain, and Tibet was under the sovereignty of the Qing. Furthermore, according to Article III, which emphasised the Qing's obligation to

prevent acts of aggression from the Tibetan side, the British affirmed again that the Qing Government possessed jurisdiction over the Tibetans. In conclusion, by analysing the Sino-British treaties relating to Tibet concluded before the twentieth century, it can be concluded that instead of recognising Tibet as an independent State, the British Government was inclined to treat Tibet as a part of the Qing Empire, and it also indirectly recognised the Qing's sovereign rights over Tibet.

\subsubsection{The Status of Tibet Before the 1911 Chinese Revolution}

At the beginning of the twentieth century, the British realised that the Sino-British Convention relating to Sikkim and Tibet of 1890 could hardly be carried out because of the Tibetan's strong opposition and the decline of the Qing's authority in Tibet. In the meantime, the expansion of Russian influence in Tibet further intensified the British concerns about India's security. It was against this background that the British launched 
a military expedition to Lhasa in $1903 .{ }^{17}$ As a consequence of the expedition, Younghusband, the British army commander, compelled the Tibetan local officials to sign the Lhasa Convention in 1904 without the adherence of the representative of the Qing. As the first legal instrument concluded between the British and the Tibetans alone, the Lhasa Convention prevented Tibet from having relations with any other foreign Powers without British consent, making Tibet's status ambiguous. ${ }^{18}$ Considering that Britain had concluded many agreements with the indigenous peoples of Africa who did not establish sovereign States in the nineteenth century, the conclusion of the Lhasa Convention itself cannot serve as evidence that the British Government recognised Tibet as a sovereign State. ${ }^{19}$ If Britain really regarded Tibet as a State, it was unnecessary for Britain to require Tibet to abide by the Sino-British Convention of 1890 in which Tibet did not participate in Article I of the Lhasa Convention. Therefore, the conclusion of the Lhasa Convention could not constitute British recognition of Tibet's independence. ${ }^{20}$ In the meantime, Tibet could neither be a British protectorate through the conclusion of the Lhasa Convention if Britain did not treat Tibet as an independent State, because a protected State should be a fully sovereign State before the conclusion of a treaty of a protectorate. ${ }^{21}$ In fact, although the Lhasa Convention prohibited Tibet from having relations with any other foreign powers without British consent, China was excluded from the term 'foreign Power' according to Younghusband's note to the ambans. This means that Britain continued to recognise that the Qing Government possessed a predominant position in Tibet's internal and external affairs at this stage, although there was a dispute between China and Britain over whether such power was sovereignty or not. By imposing heavy restrictions on Tibet's external affairs in the Lhasa Convention, Britain had significantly undermined China's external sovereignty over Tibet which the British had acknowledged in the previous Sino-British treaties concerning Tibet. However, considering that the core aims of the Lhasa Convention were to make the Tibetans fulfil the Sino-British Convention of 1890 and to exclude other foreign States, especially Russia, from interfering in Tibet's affairs, it is hard to say that the conclusion of the Lhasa Convention indicated a significant change in Britain's position on Sino-Tibetan relations, although Britain had gained some kind of control over Tibet's external policy. Just like North-East China, which became the

\footnotetext{
${ }^{17}$ See Chapter 4, Section 4.1.

${ }^{18}$ See Chapter 4, Section 4.1.3.

${ }^{19}$ See Chapter 4, Section 4.1.4.1.

${ }^{20}$ See Chapter 4, Section 4.1.4.

${ }^{21}$ Ibid.
} 
sphere of influence of Russia, and Shan Dong Province, which became the sphere of influence of Germany, Tibet began to become the sphere of influence of Britain at this stage, but in a legal sense, it was still part of China. ${ }^{22}$

Since the Lhasa Convention was not a typical treaty concluded between sovereign States in international law, its validity was questionable. To persuade China to give its adherence to the Lhasa Convention, the British concluded a new treaty with the Qing Government in 1906, namely the Convention between Great Britain and China with Respect to Tibet. The main content of this convention included the following: (1) both parties confirmed the text of the Lhasa Convention and attached it to the present convention as an annexe; (2) Britain engaged not to annexe Tibetan territory or to interfere in the administration of Tibet. China also undertook not to permit any other foreign State to interfere with the territory or internal administration of Tibet; and (3) China was excluded from being a 'foreign Power' as stipulated in Article IX (d) of the Lhasa Convention. ${ }^{23}$ Now that Younghusband's note, as the preparatory work for the Lhasa Convention, had already expressed the intention to exclude China from 'foreign Powers', and the 1906 Anglo-Chinese Convention reaffirmed that Article IX (d) of the Lhasa Convention did not apply to China, this was equivalent to an indirect recognition that the Qing Government could not only conclude treaties concerning Tibet but also interfere in Tibet's internal affairs. This description happened to fit the definition of sovereign rights. In the meantime, with the attachment of the Lhasa Convention of 1904 to this Anglo-Chinese Convention as an annexe, the Qing Government gave its retroactive recognition to the Lhasa Convention, which transformed it from a questionable legal instrument into a valid treaty between the British, the Chinese and the Tibetans in international law. ${ }^{24}$

In 1907, Britain and Russia concluded a convention relating to Tibet. By clarifying that the contracting parties could only negotiate with Tibet through the Qing Government, the Anglo-Russian Convention explicitly confirmed that Tibet's external affairs were in the hands of the Qing Government. With regard to the status of Tibet, for the first time, the Convention recognised that the Qing Government only possessed 'suzerain' rights over Tibet. ${ }^{25}$ As a concept closely related to sovereignty, suzerainty is established on

\footnotetext{
${ }^{22}$ Ibid.

${ }^{23}$ See Chapter 4, Section 4.2.1.

${ }^{24}$ See Chapter 4, Section 4.2.2.

${ }^{25}$ See Chapter 4, Section 4.3.1.
} 
the assumption that the sovereignty of a State can be divided into internal and external aspects. ${ }^{26}$ In a vassal-suzerain relationship, the external sovereignty of the vassal State is absorbed by the suzerain State though it retains internal sovereignty, which the latter is under a duty to respect. The vassal State has no position of its own in the family of nations but forms a portion of the suzerain State because of being deprived of external sovereignty. ${ }^{27}$ However, theoretical perception of suzerainty did not necessarily reflect the practices of States during the nineteenth and twentieth centuries. And due to this discrepancy between its legal definition and practice, the content of suzerainty is ambiguous as it always differs from case to case. ${ }^{28}$ In the case of Tibet, as early as the end of the eighteenth century, the Qing Government had already established authority which was similar to the sovereignty in Tibet. Although the Qing's influence in Tibet declined throughout the second half of the nineteenth century due to the British expansion in this region, the Qing's control over Tibet's internal and external affairs was still confirmed in a series of Tibet-related treaties concluded between China and Britain. Therefore, the use of 'suzerainty' by the British to define the Sino-Tibetan relations in the Anglo-Russian Convection of 1907 might not have been in line with Britain's previous treaty obligations. Furthermore, the British expedition of 1903, in turn, urged the Qing Government to restore its influence in Tibet. Through carrying out a series of reforms, the Qing Government had largely restored its capacity to influence Tibet's internal administration in its last few years. If we consider the development of the Sino-Tibetan relations during the Qing Dynasty as a whole, then the Qing Government basically maintained its influence on Tibet's internal and external affairs for most of the time from the 1790s to the 1910s, although the British involvement at one point weakened this authority. ${ }^{29}$ From this perspective, compared with the term 'suzerainty', sovereignty may be a more accurate term to define the relations between Tibet and the Qing Empire.

\subsubsection{The Status of Tibet from 1912 to 1951}

The outbreak of the 1911 Chinese Revolution not only ended the rule of the Qing Dynasty but also interrupted the Qing's deployment of consolidating sovereignty over

\footnotetext{
${ }^{26}$ See Chapter 4, Section 4.3.2.

${ }^{27}$ Ibid.

${ }^{28}$ Ibid.

${ }^{29}$ See Chapter 5, Section 5.1.
} 
Tibet. After the 1911 Revolution, the Tibetans expelled the amban and Chinese troops from Tibet. To demonstrate Tibet's independence from China, Tibet and Mongolia concluded an agreement in January 1913. Soon afterwards, the Dalai Lama issued a proclamation that was considered the declaration of Tibet's independence in February 1913. The two documents are often cited as the legal instruments proving Tibet's independence. The core content of the Mongolia-Tibetan treaty of 1913 was that Mongolia and Tibet mutually recognised each other's independent status. However, according to the constitutive theory that more reflected State practice in the early twentieth century, the recognition of States only happens between an existing recognised State and a new entity, but never between two or more new entities. In this sense, Tibet could not become an independent State until an existing State gave such recognition, and nor could Mongolia. Meanwhile, it also needed to obtain the recognition of most existing States to prove its independent status. The so-called 'Mongolian State' has neither been recognised by the Republic of China nor by other members of the international community, and the same situation also applied to Tibet. In this sense, the Mongolia-Tibetan treaty can hardly be regarded as a valid treaty in international law as both Tibet and Mongolia lacked the eligibility to conclude a treaty. Therefore, this document cannot be used as evidence of Tibet's independence. ${ }^{30}$ With regard to the Dalai Lama's proclamation of 1913, as a document intends to change the legal status of the territory whose independence is being declared, the declaration of independence should be made public, and its audience should be the subjects of international law rather than the individuals of this territory. The proclamation of 1913 was only directed at Tibetans rather than any other States. Thus, it is reasonable to argue that the Dalai Lama had no intention of making the Chinese Republican Government, Britain or Russia aware of this proclamation. Besides, a unilateral declaration of independence should explicitly express the intention to secede from the parent State, but this was not the case with the proclamation of 1913. Therefore, the Dalai Lama's proclamation did not follow the characteristics of a declaration of independence. ${ }^{31}$

In fact, instead of being an independent sovereign State, Tibet from 1912 to 1951 was more in accordance with the definition of a de facto State in international law. A de facto State exists where there is an organised political leadership that maintains its effective control over a large portion of the parent State for a significant period,

\footnotetext{
${ }^{30}$ See Chapter 5, Section 5.2.1.

${ }^{31}$ See Chapter 5, Section 5.2.2.
} 
providing governmental services and receiving popular support from the population in this land. A de facto State views itself as capable of entering into relations with other States, and it seeks widespread international recognition as a sovereign State, but it is unable to achieve any degree of substantive recognition and therefore remains illegitimate in the eyes of international society. ${ }^{32}$ In regard to the situation of Tibet from 1912 to 1951, the Tibetans expelled all the Chinese officials and soldiers from Tibet by force in 1912, which enabled them to consistently control most of Tibet without Chinese interference. In addition, there did exist an established regime exercising effective control over Tibet. This regime had the Dalai Lama as the head of the leadership of Tibet, a cabinet of ministers called the 'Kashag' to deal with administrative affairs and a national assembly called the 'Tsongdu'. On the other hand, the newly established Republic of China, as the successor of the Qing Government which inherited the Qing's sovereignty over Tibet, insisted that Tibet was an integral part of China, although it had already lost its effective control over Tibet. For Britain and Russia, they were obliged to recognise the Chinese suzerain rights over Tibet stipulated in the Anglo-Russian Convention of 1907. Given that neither the Chinese Republican Government nor any third States had ever recognised Tibet as an independent State, Tibet was more in line with the definition of a de facto State. ${ }^{33}$

As a concept describing State-like entities that are not recognised by other existing States, de facto States themselves are not the subject of international law. And apart from focusing on the Statehood of Tibet, the element that constituted Tibet's status as a de facto State might also possess some space in international law if such an element satisfies certain conditions. As previously mentioned, an organised political leadership is indispensable for a de facto State to maintain effective control over a large portion of the parent State, but considering that in most cases, the creation and survival of de facto States are the consequence of internal armed strife, such political organisations are usually treated as rebel groups by the legitimate government of the parent State or other third States. However, it does not prevent such organisations from being subjects of international law in some cases. For example, when the internal armed strife reaches the intensity of a civil war, the rebel organisation in hostilities may be recognised as a belligerent, a temporary and limited subject of international law regarding the application of the rules of war, by the legitimate government of the parent State or other

\footnotetext{
${ }^{32}$ See Chapter 5, Section 5.2.3.

${ }^{33}$ Ibid.
} 
third States. ${ }^{34}$ As for Tibet, since a series of armed conflicts broke out between the Chinese army and the Tibetan army from 1912 to 1951, there is a possibility that the Dalai Lama's regime, which controlled the most of the territory of Tibet during this period, might have met the requirements of a belligerent. As a particular subject of international law with limited legal personality, a belligerent has four primary characteristics: (1) the armed conflict between rebel groups and the established government must reach the intensity of civil war; (2) the rebel regimes must occupy a considerable portion of the parent State's territory and must be able to maintain law and order in the territory under its control; (3) the rebels must conduct hostilities in accordance with the laws of war through armed forces under a responsible authority; and (4) whether it is to overthrow the established government or secede from the parent State, the purpose of rebels should be political to distinguish it from ordinary crime. ${ }^{35}$ In this sense, if a de facto State is created and sustained for the purpose of civil war, then the rebel organisation, as the core element of such a State-like entity, may be recognised as a belligerent regarding the application of the rules of war. Back to the case of Tibet, the Dalai Lama's regime from 1912 to 1951 was basically satisfying the above characteristics for the following reasons: First, the scale and intensity of the armed conflicts between the Chinese army and the Tibetan army did amount to civil war in an international legal sense, and both hostile parties had followed the rules of war. Second, in the territorial aspect, the whole territory of central Tibet and part of Kham was under the control of the Dalai Lama's regime. Third, this regime functioned as a civil government and exercised supreme authority over the above territory. Fourth, the goal of the regime was to achieve de jure independence of Tibet, thus their hostile acts against the Chinese army were political. ${ }^{36}$ Besides, considering that the Chinese army followed the basic rules of war, which included the humane treatment and exchange of Tibetan prisoners of war, and concluded a series of truce agreements that amounted to Commercia belli from 1912 to 1951, it is reasonable to argue that the Chinese Government had implicitly recognised the Dalai Lama's regime as a belligerent during the Sino-Tibetan armed wars. ${ }^{37}$

Following this spirit, the 1914 Simla Convention concluded by the Dalai Lama's regime and the British Government can be regarded as a valid treaty between a belligerent and

\footnotetext{
${ }^{34}$ See Chapter 6, Section 6.1.1.

${ }^{35}$ Ibid.

${ }^{36}$ See Chapter 6, Section 6.1.3.

${ }^{37}$ Ibid, and also see Section 6.2.2.1.
} 
a third State, although the Chinese Government refused to sign up to the convention. However, it does not mean that each provision of that convention was valid in international law because belligerents only enjoy limited legal personality concerning the needs of civil war, for example, the protection of a third State's citizens in a territory controlled by belligerents; the compensation of damage caused by belligerents; and the maintenance of commercial relations with third States. In contrast, arrangements involving the disposal of critical sovereign rights of the parent State, such as the demarcation of borders with the third State, can hardly be considered valid because of the uncertain nature of civil war. In the absence of the Chinese Government's consent, the 'McMahon Line' delimiting the border between India and Tibet was invalid because the right of demarcation should have exclusively belonged to the Chinese Government as long as the British Government refused to recognise Tibet's independent status. ${ }^{38}$

\subsection{The Relevance of this Study and Possible Future Research Areas}

As mentioned in the introductory chapter of this thesis, the issue of Tibet's status from the late Qing Dynasty from 1840 to the restoration of Tibet by the Chinese in 1951 constitutes a core dispute between the Chinese Government and the Tibetan Government in Exile. From the perspective of the Dalai Lama's side, Tibet was an independent State during this period in the sense of international law. But according to the Chinese Government, Tibet was still under Chinese sovereignty. The determination of the status of disputed territory is not only a historical issue but also an international legal one. By examining the relevant historical facts through the lens of international legal doctrine, this study systematically analysed the claims put forward by the Tibetans, the Chinese and the British. The study concluded that Tibet was not an independent sovereign State in the eyes of the family of nations because of the lack of such recognition. Then it argued that the term 'suzerain' put forward by Britain and Russia was not an appropriate concept to describe the Sino-Tibetan relations in the late Qing Dynasty because the Qing Government not only controlled Tibet's external affairs but also restored its influence on its internal affairs to a certain extent. Moreover, the term 'suzerainty' was also not suitable to describe the relations between the Chinese Republican Government and the Dalai Lama's regime because the former had lost control over Tibet's internal administration, and meanwhile, it was also unable to

\footnotetext{
${ }^{38}$ See Chapter 6, Section 6.2.2.1.
} 
prevent Tibetans from interacting with other States, although these exchanges did not constitute the recognition of Tibet's independence. In this sense, the Chinese claim that Tibet was still under the jurisdiction of the Republican Government was also not accurate from the perspective of international law.

Instead of simply judging whether Tibet was an independent State or not, this study concludes that Tibet should be considered a de facto State from 1912 to 1951 in the context of Sino-Tibetan armed conflicts. However, as long as a de facto State is different from a sovereign State, the Chinese sovereignty over Tibet inherited by the Chinese Republican Government from the Qing Dynasty continued in the eyes of international law, although the Republican Government's control over Tibet had significantly declined during this period. Given that the previous studies on Tibet's status did not put forward a similar idea, this conclusion can be regarded as one of the important innovative aspects of this study. Apart from only emphasising the legal status of Tibet under international law, this study also explores the core element of Tibet as a de facto State - the Dalai Lama's regime. Through analysing the characteristics of this regime from 1912 to 1951, this study assumes that this political organisation was belligerent in the hostile relations with the Chinese army and makes a detailed argumentation on this point of view. Compared with the previous studies on the Sino-Tibetan wars, this study tries to explain these armed conflicts and the legal status of the Dalai Lama's regime from the perspective of the traditional rules of war regarding non-international war. And in return, these attempts may deepen the understanding of Tibet as a de facto State during the Chinese Republican era. In the practical field, seeing that a major disagreement between the Chinese Government and the Tibetan Government in Exile is the status of Tibet, this study aimed to clarify Tibet's status from the 1840 s to the 1950s, which may shed some new light on any potential dialogue on this issue in the future.

As mentioned in Chapter 6, after signing the Seventeen Point Agreement for the Peaceful Liberation of Tibet in 1951, Tibet ceased to be a de facto State and returned to the sovereign jurisdiction of the People's Republic Government. ${ }^{39}$ And consequently, although the existing political system in Tibet was not altered, ${ }^{40}$ the Dalai Lama's

\footnotetext{
${ }^{39}$ See Article I, II, IV, VIII, XV of the Agreement of the Central People's Government and the Local Government of Tibet on Measures for the Peaceful Liberation of Tibet of 1951 in Melvyn C. Goldstein, A History of Modern Tibet, 1913-1951: The Demise of the Lamaist State, University of California Press, 1991, pp 763-69. Also see Chapter 6, Section 6.1.3.2 (4)

${ }^{40}$ Ibid.
} 
regime no longer existed as a belligerent because of the end of the Sino-Tibetan war. Instead of replacing the Dalai Lama's regime with the political system implemented in China proper, this regime was maintained and recognised as the autonomous local government of Tibet within the jurisdiction of the People's Republic Government. In 1959, the Dalai Lama's regime once again launched a movement against the Central Government on the ground that the latter did not fully implement the 1951 agreement. The movement was soon suppressed, and the Dalai Lama's regime went into exile in India until now. The question arises of how to understand the legal nature of a peace agreement concluded between a belligerent and the de jure government of the parent State. Is it a treaty in the sense of international law? Is it a purely constitutional instrument in the sense of domestic law? Or does it belong to a sui generis legal regime? Moreover, what are the consequences if one party to the peace agreement does not follow the content of the agreement after the armed conflict ends? For example, if the Chinese Government did not ultimately carry out the 1951 peace agreement, would the Dalai Lama regime's belligerent status automatically revive due to the non-compliance of the other party? These questions are worthy of being answered in future research. 


\section{Samenvatting}

Hoewel er sinds 1959 veel meningsverschillen zijn tussen de Chinese regering en de Tibetaanse regering in ballingschap over de Tibet-kwestie, is een van de moeilijkste geschillen hoe de status van Tibet van het verleden tot het heden te begrijpen. Voor de Chinese regering staat Tibet sinds de 13e eeuw in de Yuan-dynastie onder de soevereiniteit van China. Daarentegen beweert de Tibetaanse regering in ballingschap dat Tibet altijd een onafhankelijke staat was geweest tot 1951, toen de Chinezen het illegaal met geweld bezetten.

In feite is het oordeel over het eigendom (of de soevereiniteit) van een regio niet alleen een historische kwestie, maar ook een kwestie van internationaal recht. Daarom wordt in dit onderzoek een interdisciplinaire benadering toegepast, die tot doel heeft de relevante historische gebeurtenissen met betrekking tot de status van Tibet binnen het kader van internationaal recht te onderzoeken. In de tussentijd, aangezien de westerse discipline van het internationaal recht pas in de late Qing-dynastie in de jaren 1840 in China werd geïntroduceerd, neemt dit proefschrift deze periode als het startpunt van het onderzoek omdat de acceptatie en toepassing van het internationale recht door de Qing het mogelijk maakten de Chinees-Tibetaanse betrekkingen en de Chinees-westerse betrekkingen met betrekking tot Tibet te observeren vanuit het perspectief van deze rechtsorde. En gezien het feit dat de regering van de Chinese Volksrepubliek sinds 1951 gestaag haar volledige controle over Tibet heeft verworven (of hersteld), kiest het proefschrift 1951 daarom als het eindpunt van dit onderzoek.

Alvorens de status van Tibet van de jaren 1840 tot de jaren vijftig te onderzoeken, moet men in gedachten houden dat alles uit zijn verleden evolueert, en zonder uitzondering het geval van Tibet. Om deze reden richt het tweede hoofdstuk van dit proefschrift zich op de bespreking van de status van Tibet vóór de jaren 1840 binnen het kader van het tribuutsysteem - een reeks regels en instellingen gebaseerd op een confucianistische ideologie die het keizerlijke China aan de top van deze hiërarchische wereld plaatste. Orde in de omgang met de omringende landen en etnische groepen. Dit hoofdstuk geeft een kort overzicht van de traditionele Chinees-Tibetaanse betrekkingen van de Tang (618-907 AD) tot het midden van de Qing-dynastie (1644-1840), en het onthult de ontwikkeling van de status van Tibet van een onafhankelijk rijk tot een buitenste 
zijrivier en uiteindelijk naar een binnenrivier onder de heerschappij van de Qing in de achttiende eeuw.

In de tweede helft van de negentiende eeuw had de interventie van Groot-Brittannië in Tibetaanse aangelegenheden de traditionele Chinees-Tibetaanse betrekkingen aanzienlijk op de proef gesteld. Daarom introduceert het derde hoofdstuk eerst China's benadering van het westerse internationale recht en de toepassing van deze rechtsorde binnen het ongelijke verdragssysteem. Daarna introduceert het hoofdstuk ook de vroege Britse betrokkenheid bij Tibet en analyseert het het Britse standpunt over de status van Tibet door drie vroege Tibet-gerelateerde verdragen tussen China en Groot-Brittannië in de tweede helft van de negentiende eeuw te onderzoeken.

Het vierde hoofdstuk onderzoekt de verandering van het Britse beleid ten aanzien van Tibet. Een belangrijke gebeurtenis was de Britse invasie van Tibet in 1903, die deze beleidswijziging direct markeerde. Als gevolg van de Britse invasie wordt de Lhasa Conventie van 1904 onderzocht om het Britse standpunt over Tibet op dat moment te illustreren. Vervolgens wordt in de rest van het hoofdstuk besproken hoe de Britten hun voordelen in Tibet consolideerden door in het begin van de twintigste eeuw een reeks verdragen met China en Rusland te sluiten, en wat hun invloed was op de status van Tibet in het begin van de twintigste eeuw.

Na de Chinese Revolutie van 1911 stortte de Qing-dynastie in en werd vervangen door de Republiek China. Ondertussen hebben de Tibetanen, om zich te ontdoen van de Chinese invloed in Tibet, alle functionarissen en troepen van het voormalige Qing-hof uit Tibet verdreven en voor het eerst in honderden jaren onafhankelijk de Tibetaanse zaken gecontroleerd. Dienovereenkomstig beweert de Tibetaanse regering in ballingschap dat Tibet van 1912 tot 1951 voldeed aan de criteria van een soevereine staat in het internationaal recht. Om deze reden wordt in de rest van het proefschrift vooral onderzocht of Tibet in deze periode als een onafhankelijke staat moet worden beschouwd, en zo niet, welke status het had vanuit het perspectief van internationaal recht? Vergeleken met het zesde hoofdstuk dat zich richt op de gewapende conflicten tussen de Chinezen en de Tibetanen van 1912 tot 1951, richt het vijfde hoofdstuk zich meer op de vreedzame aspecten van de Chinees-Tibetaanse interacties tijdens het Republikeinse tijdperk. Door de juridische gevolgen en de geldigheid van het Verdrag tussen Mongolië en Tibet van 1913 en de proclamatie die in hetzelfde jaar door de 13e 
Dalai Lama werd uitgevaardigd, te analyseren, legt het hoofdstuk eerst uit waarom Tibet geen onafhankelijke staat was. Op basis hiervan vergelijkt de rest van het hoofdstuk de kenmerken van Tibet met het concept van de facto staat in het internationaal recht en betoogt vervolgens dat Tibet moet worden beschouwd als een de facto staat in het internationaal recht van 1912 tot 1951. Naast de focus op de staat Tibet, onderzoekt het laatste hoofdstuk de mogelijkheid dat het regime van de Dalai Lama, als de hoogste autoriteit van Tibet die het kernelement vormde van een de facto staat, enige status in het internationaal recht zou kunnen hebben tegen de achtergrond van de Sino-Tibetaanse gewapende conflicten van 1912 tot 1951. Als een tijdelijk en beperkt onderwerp van internationaal recht met betrekking tot interne gewapende conflicten, worden in dit hoofdstuk het begrip oorlogvoerende partij en de erkenning ervan geïntroduceerd om na te gaan of het regime van de Dalai Lama kan worden beschouwd als een oorlogvoerende gemeenschap vanuit het perspectief van nietinternationale gewapende conflicten. Deze inspanningen zijn op hun beurt bevorderlijk voor het verdiepen van het begrip van Tibet als een de facto staat van 1912 tot 1951. 


\section{Bibliography}

\section{Books and Book Chapters}

\section{Books}

Alexandrowicz-Alexander, Charles Henry, the European-African Confrontation - A Study in Treaty Making, Leiden: Sijthoff, 1973.

Bell, Charles, Tibet - Past and Present, Oxford at the Clarendon Press, 1968.

Benton, Lauren and Lisa Ford, Rage for Order: The British Empire and the Origins of International Law, 1800-1850, Harvard University Press, 2016.

Bey, Aristarchi, 1873-88: Législation ottomane, ou recueil des lois, règlements, ordonnances, traités, capitulations et autres documents officiels de l'Empire ottoman. vol. 2. Constantinople: Imprimerie Frères Nicolaïdes; Bureau du journal Thraky.

Bodin, Jean, On Sovereignty: Four Chapters from the Six Books of the Commonwealth, edited by Julian H. Franklin, Cambridge University Press, 1992.

Bruns, Viktor, Fontes Juris Gentium: A Digest of the Diplomatic Correspondence of the European States From 1856 to 1871, Series B, Part 1, Berlin: Heymanns, 1933.

Buzan, Barry, Yongjin Zhang, Contesting International Society in East Asia, Cambridge University Press, 2014.

Calvo, Carlos, Le Droit International Theorique et Pratique, vol. 4, 1896.

Capaldo, Giuliana Ziccardi, Repertory of Decisions of the International Court of Justice (1947-1992), Nijhoff Publishers, 1995.

Chan, Phil C. W., China, State Sovereignty and International Legal Order, Brill, 2015. Chen Qingying (陈庆英), A Complete History of Tibet (Xi Zang Tong Shi), Zhongzhou Guji Press (中州古籍出版社), 2003.

Chen Qingying (陈庆英), Study on the Ponchen in Sakya regime in the Yuan Dynasty (元代萨迦本钦辨析), the Collection of Tibetan Studies, Volume 2 (藏学研究论从, 第 2 辑), Tibet People's Publishing Press (西藏人民出版社), 1990. 
Chen Ti-chiang, The International law of Recognition, With Special Reference to Practice in Great Britain and the United States, New York: Frederick A. Praeger Inc., 1951.

Chesterman, Simon, Hisashi Owada, and Ben Saul, The Oxford Handbook of International Law in Asia and the Pacific, Oxford University Press, 2019.

Crawford, James, The Creation of States in International Law, Oxford: Clarendon Press, 1979.

Das, Tarak Nath, British Expansion in Tibet, N.M. Raychowdhury \& Company, 1928.

Davis, J. F., China During the War and Since the Peace, Volume 1, Longman, Brown, Green, and Longmans, 1852.

Dawa Norbu, China’s Tibet Policy, Curzon Press, 2001.

Deng Lie (邓烈), Study on the Historical and Legal Status of Tibet in International Law (西藏历史法律地位的国际法研究), Chinese National Social Science Fund Project, 2013.

Dobratz, Betty A, Lisa K Waldner, Timothy Buzzell, Power, Politics, and Society: An Introduction to Political Sociology, Pearson, 2011, p 324.

Duojie Cai'dan (多杰才旦), Study on the relations between the Tibetan Local Government and the Central Government Since the Yuan Dynasty (元以来西藏地方政府 与中央政府关系研究), Vol.2, Chinese Tibetology Press (中国藏学出版社).

Fassbender, Bardo, The Oxford Handbook of the History of International Law, Oxford University Press, 2012.

Fleming, Peter, Bayonets to Lhasa: The British Invasion of Tibet, Tauris Parke, 2012.

Fortin, Katharine, The Accountability of Armed Groups under Human Rights Law, Oxford University Press, 2017.

Göcke, Katja, Indigenous Peoples in International Law, Göttingen University Press, 2013.

Goldstein, Melvyn C., A History of Modern Tibet, 1913-1951: The Demise of the Lamaist State, University of California Press, 1991

Goldstein, Melvyn C., The Snow Lion and the Dragon - China, Tibet, and the Dalai Lama, University of California Press, 1997. 
Gong Ying (龚荫), History of China's ethnic policies, Vol. 3 (中国民族政策史), Yunnan University Press, 2014.

Gong, Gerrit W., Standard of 'Civilization' in International Society, Oxford: Clarendon Press, 1984.

Gundry, R. S., China and Her Neighbours, London: Chapman and Hall Lyd, 1893.

Guo Rongxing, A Brief History of Tibet, in China's Regional Development and Tibet, Springer.

Hall, W. E., A Treatise on International Law, Oxford: The Clarendon Press, 1909.

Halper, Lezlee Brown, Stefan A. Halper, Tibet: An Unfinished Story, Oxford University Press, 2014.

He Wenxuan (贺文宣), Memorabilia of the Qing's amban in Tibet (清朝驻藏大臣大事记), China Tibetology Press, 1993.

Hershey, Amos, The Essentials of International Public Law and Organization, New York: The Macmillan Company, 1927.

Higgins, Rosalyn, The International Regulation of Civil Wars, Thames \& Hudson, 1972.

Hsü, Immanuel C.Y., China's Entrance into the Family of Nations: The Diplomatic Phase, 1858- 1880, Harvard University Press, 1960.

Hulle, Inge van, Britain, West Africa and the formation of imperial international law (1807-1885), PhD dissertation of KU Leuven, Faculty of Law, 2016.

Jiang Taihua (姜太华), Into the Liberation War (走进解放战争), Vol. 2, China Literature and Art Press (中国文艺出版社), 2009.

Kellam, Amy, Foreign Devils: Law's Imperial Discourse and the Status of Tibet, the PhD thesis submitted for the Department of Law, SOAS, University of London, 2013.

Kelsen, Hans, Principles of international law, New York: Holt, Rinehart and Winston, 1966.

Kuleshov, Nikolai S., Russia's Tibet File - The unknown pages in the history of Tibet's independence, Library of Tibetan Works and Archives, 1996.

Lamb, Alastair, British India and Tibet 1766-1910, Routledge \& Kegan Paul Press, 1986. 
Lamb, Alastair, the McMahon Line: A Study in the Relations between India China and Tibet, 1904 to 1914, University of Toronto Press, 1966.

Lamb, Alastair, Tibet, China \& India, 1914-1950: a history of imperial diplomacy, Roxford Books, 1989.

Lattimore, Owen, Studies in Frontier History, New York, 1962.

Lauterpacht, Hersch, Recognition in International Law, Cambridge University Press, 1947.

Lauterpacht, Hersch, the collected papers, vol 1, Cambridge University Press, 1970.

Lawrence, T. J., The Principles of International Law, Boston: D.C. Heath \& Co, 1923.

Li Tieh-tseng, The Historical Status of Tibet, King's Crown Press, Columbia University, New York, 1956.

Li Tieh-tseng, Tibet Today and Yesterday, New York: Bookman Associates, 1960.

Li Xiaobing, Ethnic China: Identity, Assimilation, and Resistance, Lexington Books, 2015.

Li Yunquan (李云泉), Chaogong zhidu shilun: Zhongguo gudai duiwai guanxi tizhi yanjiu (朝贡制度史论-中国古代对外关系体制研究, A History of the Tribute System: Research on China's Premodern Foreign Relation Institution), Beijing: Xinhua Press (新华出版社), 2004.

Lin, Hsiao-ting, Tibet and Nationalist China's Frontiers, Intrigues and Ethnopolitics, 1928-49, UBC Press, 2006.

Liu Tong (刘统), the Study of Tang Dynasty's Jimifuzhou. (唐代羁縻府州研究) Xi'an: Northwest University Press (西北大学出版社), 1998.

Lu Xingqi (陆兴祺), Xizang Jiaoshe Shiyao (西藏交涉始末, Important Diplomatic Dealings Concerning Tibet), published by Mongolian and Tibetan Affairs Commission.

Luo Shaoming (罗绍明), The Study on the Tibet Policy During the Republic of China (民国时期西藏政策研究), the doctoral dissertation of Southwest University for Nationalities, 2013.

Markham, Clements R., Narratives of the Mission of George Bogle to Tibet, and of the Journey of Thomas Manning to Lhasa, London 1876. 
Mayers, William Frederick, Treaties between the Empire of China and foreign powers, Shanghai: North-China Herald Office, 1902.

McLaughlin, Robert, Recognition of Belligerency and the Law of Armed Conflict, Oxford University Press, 2020.

McNair, Arnold Duncan, The Law of Treaties: British Practice and Opinions, Oxford University Press, 1938.

Mixed Commission on British and American Claims, British and American Claims: British Claims No. 1 to 478 Memorials, Demurrers, Briefs, and Decisions, Issues 427$432,1873$.

Mohammed, Bedjaoui, International Law: Achievements and Prospects, Nijhoff Publishers, 1991.

Moir, Lindsay, The Law of Internal Armed Conflict, Cambridge University Press, 2002.

Moore, John Bassett, A Digest of International Law, Vol. 1, Washington: Government Printing Office, 1906.

Nakajima, Gakusho, The Structure and Transformation of the Ming Tribute Trade System, in Global History and New Polycentric Approaches edited by Manuel Perez GarciaLucio De Sousa, Palgrave Macmillan, 2018.

Noorani, A.G, India-China Boundary Problem 1846-1947, Oxford University Press.

Nozari, Fariborz, Unequal Treaties in International Law, the Doctoral Thesis of the Law School of the University of Stockholm,1971.

Oppenheim, Lassa, International Law: A Treaties, Vol.1, London: Longmans, Greens and Co., 1905.

Ou yangxiu (欧阳修), Song qi (宋祁), New history of the Tang Dynasty (新唐书), Zhonghuashuju Press (中华书局), 1975 .

Padelford, Norman J., International Law and Diplomacy in the Spanish Civil Strife, The Macmillan Company, 1939.

Palace, Wendy, the British Empire and Tibet 1900-1922, Routledge Curzon, 2005.

Pegg, Scott, International Society and the De Facto State, Aldershot / Brookfield, 1998. 
Peng Jianying (彭建英), The Evolution of the Jimi Policy in Ancient China (中国古代羁 縻政策的演变), China Social Science Press(中国社会科学出版社), 2004.

Peyrefitte, Alain, the Immobile Empire, Knopf Doubleday Publishing Group, 2013.

Praag, Michael C. van Walt van, A Legal Examination of the 1913 Mongolia-Tibet Treaty of Friendship and Alliance, in The Centennial of the Tibeto-Mongol Treaty: 1913-2013, Dharamshala: Amnye Machen Institute, 2013.

Praag, Michael C. van Walt van, The Status of Tibet: History, Rights, And Prospects In International Law, Westview Press, 1987.

Pradhan, Queeny, Empire in the Hills: Simla, Darjeeling, Ootacamund, and Mount Abu, 1820-1920, Oxford University Press, 2017.

$\mathrm{Pu}$ Wencheng (蒲文成), Wang Xinyue (王心岳), The History of Relationships Between the Chinese Han and Tibetan (汉藏民族关系史), Gansu People Publishing Company (甘 肃人民出版社), 2008.

Pufendorf, Samuel, De jure Naturae et Gentium Libre octo, Classics of International Law, Oxford: Clarendon Press, 1934.

Qing Shilu (清实录), vol. 58, Zhonghua Shuju (中华书局), 1987.

Richardson, Hugh Edward, A Short History of Tibet, New York: E.P. Dutton \& Co, 1962.

Richardson, Hugh Edward, Tibet and Its History, Boullier \& London, 1984.

Roberts, Anthea, Is International Law International? Oxford University Press, 2017. Rougier, Antoine, Les Guerres Civiles et le Droit des Gens, 1903.

Sen Tansen, India, China, and the World: A Connected History, Rowman \& Littlefield, 2017.

Shakabpa, Tsepon Wangchuk, One Hundred Thousand Moons: An Advanced Political History of Tibet, Brill, 2010.

Shakabpa, Tsepon Wangchuk, Tibet: A Political History, Yale University Press, 1967.

Shawn, Malcolm N., International law, Cambridge University Press, 2017.

Shotwell, James T., A Short History of the Question of Constantinople and the Straits, Greenwich, New York, 1922. 
Singh, Amar, Himalayan Triangle - A Historical Survey of British India's Relations with Tibet, Sikkim and Bhutan 1765-1950, published by the British Library, 1988.

Smith, H. A., Great Britain and the Law of Nations, Vol. 1, London: P.S. King, 1932.

Smith, Warren W., Tibetan Nation - A History of Tibetan Nationalism and Sino-Tibetan relations, Westview Press, 1996.

Soroka, Marina, Britain, Russia and the Road to the First World War: The Fateful Embassy of Count Aleksandr Benckendorff, Routledge, 2016.

Sperling, Elliot, The 5th Karma-pa and Some Aspects of the Relationship between Tibet and the Early Ming Dynasty, in the History of Tibet, Volume II, Routledge Curzon.

Sykes, Percy, The Right Honourable Sir Mortimer Durand, London: Cassell and Company, 1926.

Takashi Okamoto, A World History of Suzerainty: A Modern History of East and West Asia and Translated Concepts, Toyo Bunko, 2019.

Than, Mya, Myanmar's External Trade: An Overview in the Southeast Asian Context, Institute of Southeast Asian,1992.

The Boundary Question Between China and Tibet: A Valuable Record of the Tripartite Conference Between China, Great Britain and Tibet Held in India, 1913-1914, published in Peking, China, 1940.

The Fifth Dalai Lama, A History of Tibet by the fifth Dalai Lama (西藏王臣记), translated by Liu Liqian (刘立千), Publishing House of Minority Nationalities (民族出 版社), 2000.

Tibetan Social and Historical Survey Data Series Editing Group (西藏社会历史调查资 料丛刊编辑组), Tibetan Social History Survey (藏族社会历史调查), Vol. 3, Xizang Renmin Press, 1989.

Tongzhi Chao Chouban Yiwu Shimo (同治朝筹办夷务始末, Complete Record of the Management of Barbarian Affairs: Emperor Tongzhi) vol 26, Zhonghua Shuju Press (中 华书局), 2008.

Turmanidze, Sergo, Status of the De Facto State in Public International Law, PhD Dissertation, the University of Hamburg, 2010.

Vattel, Emer de., the Law of Nations, Philadelphia, 1844. 
Walker, E., The Addresses and Messages of the Presidents of the United States from Washington to Harrison, New York, 1841.

Wang Tieya, International Law in China: Historical and Contemporary Perspectives, Recueil des Cours, 1990, II.

Wheaton, Henry, Elements of International Law 6th edition, vol 1, London: Stevens \& Sons Ltd, 1929.

Wilson, Heather A., International Law and the Use of Force by National Liberation Movements, Oxford University Press, 1988.

Wu Fengpei (吴丰培), Lian Yu's Memorials in Tibet (联豫驻藏奏稿), Tibet people's Publishing House (西藏人民出版社), 1979.

Wu Fengpei (吴丰培), The Memorials of Tibetan Affairs in the Qing Dynasty(清代藏事 奏牍), the Chinese China Tibetology Press, 1994.

Wu Fengpei (吴丰培), the Telegraph of Tibetan Affairs in the First Year of Chinese Republic (民元藏事电稿), Xi Zang Renmin Press, 1983.

Ya Hanzhang (牙含章), The Portrait of Dalai Lama (达赖喇嘛传), SDX Joint Publishing Company (三联书店), 1963.

Yang Zewei (杨泽伟), Study on the History of International Law (国际法史论), 2nd ed., Higher Education Press (高等教育出版社), 2011.

Yang Zhonghua (杨仲华), Xikang Jiyao (西康纪要) vol.2, Shangwu Yinshuguan (商务印 书馆), 1937.

Younghusband, Francis E., India and Tibet, London: John Murray, Albemarle Street, $1910, \mathrm{p} 264$.

Younghusband, Francis E., Memorandum on Our Relations with Tibet - Both Past and Present, Simla: Printed at the Government Central Printing Office, 1903.

Zhang tingyu (张廷玉), Mingshi (明史), volume 28, Zhonghua Book Company (中华书 局), 1974.

Zhang Tong (张枬), Selected Works of Public Opinion in the Ten Years Before the 1911 Revolution (辛亥革命前十年间时论选集), Sanlian Press, 1963. 
Zhang Yongjin, System, Empire and State in Chinese International Relations, in Michael Cox, Empires, Systems and States: Great Transformation in International Politics, Cambridge University Press, 2001.

Zhang Yun (张云), Tibet's history of Border Affairs, Governance and Officials (西藏历 代的边事边政与边吏), Social Sciences Literature Press (社会科学文献出版社), 2015.

Zhao Yuntian (赵云田), The Study on New Policies in Late Qing Dynasty(清末新政研 究), Heilongjiang Education Press, 2014.

Zhao, George Qingzhi, Marriage as Political Strategy and Cultural Expression: Mongolian Royal Marriages from World Empire to Yuan Dynasty, Peter Lang Publishing 2008.

Zhu Xiu (朱绣), Sixty-Year Chronology of Tibet (西藏六十年大事记), Qinghai People's Press (青海人民出版社), 1996.

\section{Book Chapters}

Crawford, James, Response to Experts Reports of the Amicus Curiae, in Selfdetermination in International Law: Quebec and Lessons Learned, Martinus Nijhoff Publishers, 2000.

Dīrgha Āgama, the English translation can be seen in Shohei Ichimura, the Canonical Book of the Buddha's Lengthy Discourses, Vol. III, BDK America, 2018.

Fairbank, John K., 'A preliminary Framework' in The Chinese world order: traditional China's foreign relations, Harvard University Press, 1968.

Fairbank, John K., 'The creation of the treaty system' in the Cambridge History of China, Vol. X, Cambridge University Press, 1978.

Kawashima, Shin, China, in the oxford handbook of history of international law, the oxford university press, 2012.

Preiser, W, History of the law of nations: basic questions and principles in R Bernhardt Encyclopedia of public international law, 2nd ed., Elsevier North-Holland, 1995, vol 2.

Tappan, Eva March, ed., China, Japan, and the Islands of the Pacific, Vol. I of The World's Story: A History of the World in Story, Song, and Art, Boston: Houghton Mifflin, 1914.

\section{Journal Articles}


Alexandrowicz-Alexander, Charles Henry, The Legal Position of Tibet, American Journal of International Law, Volume 50, Issue 2, 1956.

Andreyev, Alexandre, Indian Pundits and the Russian Exploration of Tibet: An Unknown Story of the Great Game Era, Central Asiatic Journal, 2001, Vol. 45, No. 2.

Anzilotti, Dionisio, Cours de Droit International, Gidel trans, 1929.

Armitage, David, The Contagion of Sovereignty: Declarations of Independence since 1776, South African Historical Journal, Vol. 52, 2005.

Baker, P. J, the Doctrine of Legal Equality of States, British Year Book of International Law, 1923-1924.

Bennion, Tom, Treaty-Making in the Pacific in the Nineteenth Century and the Treaty of Waitangi, Victoria University of Wellington Law Review 35, 2004.

Carrai, Maria Adele, Learning Western Techniques of Empire: Republican China and the New Legal Framework for Managing Tibet, Leiden Journal of International Law, vol. 30, Issue 4,2017.

Chen Nina (程尼娜), Jimi and Diplomacy: Two Kinds of Tributary System in Ancient China: Centering on Ancient Northeast Asia (羁縻与外交: 中国古代王朝内外两种朝贡体 系一一以古代东北亚地区为中心), Collected Papers of History Studies (史学集刊), Vol. 4, 2014.

Craven, Matthew, What Happened to Unequal Treaties? The Continuities of Informal Empire, Nordic Journal of International Law 74, 2005.

Dajani, Omar M., Contractualism in the Law of Treaties, Michigan Journal of International Law, Vol. 34, 2012.

Dhokalia, R. P., Civil wars and International law, Indian Journal of International Law, 219, 1971.

Diplock, Kenneth, Passports and Protection in International Law, Transactions of the Grotius Society, Vol. 32, 1946.

Elleman, Bruce A., Secret Sino-Soviet Negotiations on Outer Mongolia, 1918-1925, Pacific Affairs, Vol. 66, No. 4, 1993.

Fairbank, J. K., and S. Y. Teng, On the Ch'ing Tributary System, Harvard Journal of Asiatic Studies, Vol. 6, 1941. 
Fenwick, Charles G., Recognition of the Czechoslovak Nation, The American Political Science Review, Vol. 12, No. 4, 1918.

Florea, Adrian, De Facto States: Survival and Disappearance (1945-2011), International Studies Quarterly, Volume 61, Issue 2, June 2017.

Fresa, Lucia, A new interpretation of the term 'indigenous people': what are the legal consequences of being recognised as 'minorities' instead of as 'indigenous people' for the indigenous people of the world? See http://www.studiperlapace.it/documentazione/fresa.html\#TWO.

Gunn, Brenda L., Exploring the International Character of Treaties 1-11 and the Legal Consequences, Canada in International Law at 150 and Beyond Paper No. 5.

Hu Zhongliang (胡忠良), Cong Dang'an Tan Wanqing Ouzhouren Zai Hua Youli (从档 案谈晚清欧洲人在华游历, the Study of Europeans' Traveling in China during the Late Qing Dynasty from the Perspective of Archives), Lishi Dang'an (历史档案, Historical Archives), vol. 2, 2002.

Hulle, Inge van, Grotius, Informal Empire and the Conclusion of Unequal Treaties, Grotiana 37, 2016.

Hyde, Charles Cheney, Concerning the Interpretation of Treaties, American Journal of International Law, Volume 3, Issue 1, 1909.

Jian Junbo, the Chinese Tribute System - Conceptual structure and functions, International Political Studies (2009), 1.

Jimenez, Alberto Alvarez, Boundary Agreements in the International Court of Justice's Case Law, 2000-2010, the European Journal of International Law Vol. 23 no. 2, 2012.

Kassoti, Eva, The Sound of One Hand Clapping: Unilateral Declarations of Independence in International Law, German Law Journal, Vol. 17 No. 02, 2016.

Keene, Edward, The Treaty-Making Revolution of the Nineteenth Century, The International History Review, Volume 34, 2012.

Kelke, W., Feudal Suzerains and Modern Suzerainty, Law Quarterly Review, Vol. 12, Issue 3, 1896.

Kellam Amy, Suzerainty and the 1914 Simla Agreement, Jus Gentium: Journal of International Legal History, Vol. 3, 2018. 
Kolmas, Josef, Tibet and Imperial China - Survey of Sino-Tibetan relations up to 1912, Centre of Oriental Studies, Australian National University, 1967.

Koskenniemi, Martti, Histories of International Law: Dealing with Eurocentrism, Rechtsgeschichte, 19, 2011.

Kumar, Krishan, Nation-States as Empires, Empires as Nation-States: Two Principles, One Practice? Theory and Society volume 39, 2010.

Landauer, Carl, Regionalism, Geography, and the International Legal Imagination, Chicago Journal of International Law, Vol. 11: No. 2, 2011.

Lauterpacht, Hersch, Note 144 in Recognition of States in International Law, the Yale Law Journal, Vol. 53, 1944.

Lesaffer, Randall, The End of the Cold War: An Epochal Event in the History of International Law? Tilburg Working Paper Series on Jurisprudence and Legal History, No. 10, 2010.

Lester, A., Bizerta and the Unequal Treaty Theory, the International and Comparative Law Quarterly, 1962.

Li Zhonghe's (李中和) dissertation, Study on the Relationship Between Tubo Dynasty and Its Neighboring Ethnic Groups (吐蕃王朝与周边民族关系研究), Lan Zhou University, 2009.

Lootsteen, Yair M., The Concept of Belligerency in International Law, no. 166, Military Law Review, 2000.

Luo Zhao, The Status of China's Sovereignty in Tibet during the Ming Dynasty, China Tibetology, No. 1, 2015.

Mckay, Alex, The British Invasion of Tibet, 1903-04, Inner Asia, Vol. 14, No. 1.

Mehra, Parshotam, The Great Game: Russia's Role in the Persian Empire and Tibet, Asian Affairs, 2004, Volume 35, Issue 2.

Negro, Guilherme Del, The Validity of Treaties Concluded under Coercion of the State: Sketching a TWAIL Critique, European Journal of Legal Studies, Vol. 10, 2017.

O'Rourke, Vernon A., Recognition of Belligerency and the Spanish War, Vol. 31, No. 3, American Journal of International Law, 1937. 
Powers, Robert D., Insurgency and the Law of Nations, the Judge Advocate General of the Navy (JAG) Journal, Vol. 16, Issue 4 (May 1962).

Rabinowitz, Adam, It's About Time: Historical Periodization and Linked Ancient World Data, Institute for the Study of the Ancient World Papers 7 (2014).

Rahim, Oleh Muniroh, International Law and Third Parties, Opinio Juris, Volume 1, January, 2010.

Rasilla, Ignacio de la, The Problem of Periodization in the History of International Law, Law and History Review, Vol. 37, No. 1, 2019.

Rubin, Alfred P., The Position of Tibet in International Law, the China Quarterly, vol. 35, 1969.

Rubin, Alfred P., Tibet's Declarations of Independence? the American Journal of International Law, Vol. 60, No. 4, 1966.

Sanderson, Henry, Transgression of the Frontier: An Analysis of Documents Relating to the British Invasion of Tibet, Inner Asia, 2012, Vol. 14, No. 1.

Schrecker, John, For the Equality of Men - For the Equality of Nations: Anson Burlingame and China's First Embassy to the United States, 1868, Journal of AmericanEast Asian Relations 17, 2010.

Shepheard, Wallwyn, Suzerainty, Journal of the Society of Comparative Legislation, Vol. 1, No. 3, 1899.

Slobodnik, Martin, The Relations Between the Chinese Ming Dynasty and the Tibetan Ruling House of Phag-mo-gru in the Years 1368 - 1434, Political and Religious Aspects, Asian and African Studies, 13, 2004.

Smith, H. A., Some Problems of the Spanish Civil War, the British Year Book of International Law, 18, 1937.

Steiger, Heinhard, From the International Law of Christianity to the International Law of the World Citizen-Reflections on the Formation of the Epochs of the History of International Law, Journal of the History of International Law Vol. 3, 2001.

Sun Jing (孙静), the Study on the Border Security Function of the Huimeng between the Tang Dynasty and Tibet Empire (试论吐蕃与唐会盟的安边功能), Heilongjiang Chronicles (黑龙江史志), Vol. 9, 2014. 
Sun jing's (孙静) dissertation, A Study on the Border Dispute Between the Tang and the Tubo Dynasty (唐朝解决唐蕃边界争端的方法研究), Lan Zhou University, 2015.

Svarverud, Rune, 'Re-Constructing East Asia: International Law as Inter-Cultural Process in Late Qing China', 12 Inter-Asia Cultural Studies ,2011.

Talalayev, A. N., Unequal Treaties as a Model of Prolonging the Colonial Dependence of the New States of Asia, and Africa, Sovietskii Ezhegodnik Mezhdynarodnogo Prava, 1961.

Tan Chung, The Unequal Treaty System: Infrastructure of Irresponsible Imperialism, China Report, XVII, 5, 1981.

Vadi, Valentina, International Law and Its Histories: Methodological Risks and Opportunities, Harvard international law journal, Vol. 58, No. 2, 2017.

Wang Chuan (王川), The Establishment of Western Kham Province and Its Significance (近代民族关系史上的西康建省及其历史意义), Journal of Tibet University, 2008, Vol.23 No.1.

Wang Haibing (王海兵), Game of Power in the Process of Sikang Provincialization (西 康省制化进程中的权力博亦), China's Borderland History and Geography Studies (中国 边疆史地研究), Vol.18 No.3, 2008.

Wang Jiguang (王继光), The Modern Explanation of Military Garrison Stations in Amdo in the History of the Ming (18 世纪中国第一部安多藏区史 一 《明史西番诸卫传》 的现代诠释), China Tibetology (中国藏学), No.4, 2006.

Wang Yongbin (王永斌), the Study on the Establishment of Sikang Province and Its Historical Role(论西康建省及其历史作用), the dissertation of Tibet University of Nationalities, 2012.

Wang Yuankang, Explaining the Tribute System: Power, Confucianism, and War in Medieval East Asia, Journal of East Asian Studies 13 (2013).

Worster, William Thomas, Relative International Legal Personality of Non-State Actors, Brooklyn Journal of International Law, Vol. 42, No. 1, 2016.

Wu Jingping (吴景平), Selected Translations of Historical Documents in the U.S. Diplomatic Archives Concerning the Negotiations between China, America and Britain on the Tibet Issue (美国外交档案中有关中美英三国交涉西藏问题的史料选译), Journal of Anti-Japanese War Research (抗日战争研究), 1994, Vol.3. 
Xin Yulin (辛宇玲), the Study on the Establishment of Sikang Province (西康建省研究), the dissertation of Minzu University of China, 2005.

Yang Zewei, Western International Law and China's Confucianism in the 19th Century -Collision and Integration, Journal of the History of International Law, Vol. 13, 2011.

Zhao Yuantian (赵云田), A Brief Review on Administration of Lifan Yuan Over Tibet During the Qing Dynasty (略谈清代理藩院对西藏的治理), Tibetan Studies (西藏研究), 1984, volume 3 .

Zhao Yuntian, Discussion on Tibet's New Policy in the Late Qing Dynasty (清末西藏新 政述论), Modern Chinese History Studies, vol.5, 2002.

Zhao Zhongshu, Round Sky and Square Earth (Tian Yuan Di Fang): Ancient Chinese Geographical Thought and its Influence, History of Geographical Thought, Vol. 26, No. 2, 1992.

Zhu Yuan Yi, Suzerainty, Semi-Sovereignty, and International Legal Hierarchies on China's Borderlands, Asian Journal of International Law, 2020.

\section{International Legal Documents}

Aitchison, C. U., Collection of Treaties, Engagements and Sanads, vol 14, Calcutta 1929-31.

Final Report of the Committee on the Rights of Indigenous Peoples, International Law Association, Sofia Conference, 2012.

Fitzmaurice, Third Report, in the Yearbook of the International Law Commission, Vol. II, 1958; Waldock, YILC, Vol. I, 1962, 639th Meeting.

Guiding Principles applicable to unilateral declarations of States capable of creating legal obligations by International Law Commission, UN Doc A/61/10 (2006).

ILC, 'Report on the Law of Treaties by J.L. Brierly, Special Rapporteur' (14 April 1950) UN Doc A/CN.4/23.

Institute of International Law, Resolution on Rights and Duties of Foreign Powers as Regards the Established and Recognized Governments in Case of Insurrection, Neuchatel meeting, September 8, 1900.

Miguel Alfonso Martínez, Study on treaties, agreements and other constructive arrangements between States and indigenous populations, Final report, 1999, para 55. 
The Geneva Convention relative to the Protection of Civilian Persons in Time of War, 1949.

The Geneva Convention Relative to the Treatment of Prisoners of War, 1949.

The Hague Regulations respecting the Laws and Customs of War on Land of 1907.

The Hague Regulations respecting the Laws and Customs of War on Land of 1907.

The Swiss Federal Constitution of 1874.

The Yearbook of the International Law Commission, vol 2, 1966.

Travers Twiss, 'Rapport', 3-4 Annuaire Institut de Droit International (1879-1880).

\section{Case Law}

Accordance with International Law of the Unilateral Declaration of Independence in Respect of Kosovo, Advisory Opinion, 2010 1.C.J. 403, 175 (July 22); the Kosovo Advisory Opinion, C.R. 2009/31, 46 (Dec. 9, 2009), statements of Norway, Jordan, France and US.

Baldy v. Hunter, United States Supreme Court 171 U.S. 388 (1898).

Boundaries in the Island of Timor, Netherlands v Portugal, Award by Permanent Court of Arbitration, 25 June 1914.

Case Concerning the Territorial Dispute (Libyan Arab Jamahiriya/Chad), ICJ Judgment of 3 Feb. 1994, ICJ Rep 6, at para. 45.

Case of Honduras v. Salvador and Guatemala of 1908.

Case of Salvador Prats v. the United States of America, Mixed Commission established under the Convention concluded between the United States of America and Mexico on 4 July 1868.

Island of Palmas Case (United States v The Netherlands), Award, 4 April, 1928, 2 RIAA 829 (PCA).

Simon v The Queen, (1985) 2 SCR 387 at para 33.

The Prize Case, 67 U.S. 6351863.

The Santissima Trinidad, 20 U.S. 283 (1822). 
The Territorial Jurisdiction of the International Commission of the River Order - United Kingdom, Czechoslovakia, Denmark, France, Germany, Sweden v. Poland, PCIJ Series A no. 23.

U.S. Supreme Court, the Prize Cases, 67 US (2 Black) 635 (1863).

United States v. the Ambrose Light, 25 F. 408, District Court, Southern District of New York, September 30, 1885.

\section{Historical Archives}

Archives of the Mongolian and Tibetan Institute of the Republic of China (民国政府蒙 藏院档案), 1045/388, 1 November,1918.

Collected Archives on Tibet and Tibetan Affairs Stored by the Second Historical Archives of China (中国第二历史档案馆所存西藏和藏事档案汇编).

Compilation of Historical Archives of the Relationship between Tibet and the Central Government since the Yuan Dynasty (元以来西藏地方与中央政府关系档案史料汇编), vol.6, compiled by the second historical archives of China, p 2346.

FO /881/9231, Enclosure in No. 57, Extract from the "Peking Gazette" of July 18, 1907.

FO /93/105/1, Convention between Great Britain and Tibet, Foreign Office Records.

FO/17/1108, India Foreign Letter No. 128 of 21 July, 1888.

FO/17/756, Fraster No. 142 of 16 July, 1877.

FO/17/984, O’Conor No. 423 of 10 Oct, 1885.

FO/17/1063, O’Conor No. 178 of 31 May,1886.

FO/17/1745, The Director-General of Mobilization and Military Intelligence presents his compliments to the Under Secretary of State for Foreign Affairs, 2th of October, 1902.

FO/17/1752, Foreign Office Memo on the Agreement with Tibet, dated of 25 September, 1904.

FO/371/1328, Memorandum communicated to Wai-chiao Pu by Sir. J. Jordan, enclosed in Jordan to Grey, no. 349, 17 August 1912. 
FO/371/135756, aide-memoire sent by the U.S. Department of State to the British Embassy in Washington, D.C., dated 15 May 1943.

FO/371/184454, telegram from the United Kingdom's U.N. delegation to the British Foreign Office, dated 14 November of 1950.

FO/375/35755, Tibet and the question of Chinese suzerainty, dated 10 April of 1943.

FO/535/15, Enclosure in no. 193, memorandum communicated to Wai-chiao Pu by Sir. Jordan, 17 August, 1912.

FO/535/15, Enclosure in no. 193, see note 24.

FO/535/15, Enclosure in no. I50, Jordan's memo on 23 June, 1912.

FO/535/15, no. 67, Jordan to Grey, 27 April 1912.

FO/535/15, No. 90, John to Grey, 8 June, 1912; PEF, 1912,69 No. 3460/12, John to Grey, 17 August 1912.

FO/535/16, No. 88, Enclosure 1, 1913.

FO/535/17, Enclosure in no. 231, Final memorandum of the Tibet Conference, 8 July, 1914.

FO/535/17, No.231, Enclosure 8.

FO/535/18, no.43, Sir Edward Grey to Sir J. Jordan, 5 October, 1915.

FO/535/20, no. 15, 16, Communications between the India Office and Foreign Office, 11, 12 December 1917.

FO/93/105/1, Convention between Great Britain and Tibet, Foreign Office Records.

Han Kuang-chun, A Record of the Sino-Tibetan Armistice Negotiations in the Seventh Year of the Republic of China (民国七年汉藏构兵停战交涉纪实) in Bian Zheng (边政), Vol. 7, 1931.

IOR/2252/43, Peel to H. Ashely Clarke, May of 1943.

IOR/L/PARL/2/334, Enclosure in No. 159, Regulations for the Future Administration of Batang, Dispatch from the Acting Consul-General, Cheng-tu, to Sir. Jordan, dated 29th December, 1906. 
IOR/L/PARL/2/334, Enclosure in No. 182.

IOR/L/PARL/2/334, Enclosure in No. 205, Summary of a Memorial by the Board of Finance respecting Tibet, approved by Imperial Rescript of 20th June, 1907; Enclosure in No. 247, Memorial from Lian Yu, the Imperial Resident, on the establishment of a printing office and of a military college in Tibet, 2nd June, 1908.

IOR/L/PARL/2/334, Enclosure in No. 247, Memorial from Lian Yu, the Imperial Resident, on the establishment of a printing office and of a military college in Tibet, 2nd June, 1908.

IOR/L/PARL/2/334, Enclosure in No. 249, Extract from the "Peking Gazette" of 19th July, 1908 - Imperial Decree.

IOR/L/PARL/2/334, Enclosure in No. 258, Rules for the reception of the Dalai Lama sent form the Grand Council to the Board of Dependencies, the Board of Interior, and the comptrollers of the Imperial Household, 30th September, 1908.

IOR/L/PARL/2/334, Enclosure in No. 260, Note from the Wai-wu Pu to the Doyen of the Diplomatic Body, dated 8th October, 1908.

IOR/L/PARL/2/334, Enclosure in No. 262, Memorandum, Dispatch from Sir. J. Jordan to Sir. Edward Grey, date Peking, 25th October, 1908.

IOR/L/PARL/2/334, Enclosure in No. 264, Imperial Decree issued in the name of the Empress Dowager.

IOR/L/PARL/2/334, Enclosure in No. 34, Summaries of Articles in the Russian Press.

IOR/L/PARL/2/334, Enclosure in No. 56, Letter from Sir E. Satow to Prince Ch'ing, dated September 9, 1902.

IOR/L/PARL/2/334, No. 109; No. 115; No. 126.

IOR/L/PARL/2/334, No. 123, From the Viceroy to the Secretary of State for India, dated 26th of October, 1903.

IOR/L/PARL/2/334, No. 129, Letter from the Government of India in the Foreign Department to His Majesty's Secretary of State for India, dated Simla, the 5th of November, 1903.

IOR/L/PARL/2/334, No. 144. 
IOR/L/PARL/2/334, No. 146, Note from Chang Ta-jen to Marquess of Lansdowne, dated Chinese Legation, London, the 23rd November, 1903.

IOR/L/PARL/2/334, No. 148, Note from Marquess of Lansdowne to Chang Ta-jen, dated the 28th November, 1903.

IOR/L/PARL/2/334, No. 149.

IOR/L/PARL/2/334, No. 230, From Sir. J. Jordan to Sir. Edward Grey, dated Peking 6th March, 1908.

IOR/L/PARL/2/334, No. 35, Dispatch from Sir C. Scott to the Marquess of Lansdowne, dated St. Petersburg, July 4, 1901.

IOR/L/PARL/2/334, No. 39, Dispatch from the Marquess of Lansdowne to Sir C. Scott, dated Foreign Office, August 16, 1901.

IOR/L/PARL/2/334, No. 49, Dispatch from Sir E. Satow to Marquess of Lansdowne, dated Peking, August 5, 1902.

IOR/L/PARL/2/334, No. 52, Telegraph from the Marquess of Lansdowne to Sir. Satow, dated September 1, 1902.

IOR/L/PARL/2/334, No. 83, Dispatch from the Marquess of Lansdowne to Sir C. Scott, dated April 8, 1903.

IOR/L/PS/10/714, E. Teichman to Jordan, 21 August of 1918.

IOR/L/PS/10/714, Enclosure 3 of Teichman to Jordan, 11 October of 1918.

IOR/L/PS/11/46, No. 723, 1913.

IOR/L/PS/11/46, Register No. 1581, Sir Edward Grey to Sir G. Buchanan, March 11. 1913.

IOR/L/PS/12/41944, Foreign Office to Secretary of State for India, S. W. L, 29 April of 1943.

$\mathrm{IOR} / \mathrm{L} / \mathrm{PS} / 20 / \mathrm{MEMO} 27 / 6$.

IOR/W. P. (43)/275, War Cabinet, Status of Tibet, 23 July of 1943. 
Liu Tsan-ting, the Actual Situation of Sino-Tibetan War and Negotiations from 1917 to 1918 (民六民七年康藏战争及交涉之实况) in Kangzang Qianfeng (康藏前锋), Vol.2, no.1, 1934.

Liu Wenhui (刘文辉), The Theory and Practice of Building a New Sikang (建设新西康 之理论与实际), in Kangdao Yuekan (康导月刊), 1944, vol 5, no.10.

Papers of George Bogle: Hamilton to Bogle, 30 May. The document is in the India Office Library.

Selected Archives of Modern Kham District (近代康区档案资料选编), by Sichuan Institute of Nationalities (四川民族研究所), 1990.

The Historical Materials of Sichuan Yunnan Border Affairs Archives in the Late Qing Dynasty (清末川滇边务档案史料).

The Record of Tibet Case (藏案纪略), written by the Foreign Ministry of Republic of China (北洋政府外交部编), 1912 .

The Telegraph of Tibetan Affairs in the First Year of Chinese Republic, Xi Zang Renmin Press, 1983.

USFR, 693.0031 Tibet/7-2648, Memorandum of Conversation of J. F. Melby, second secretary, U.S. Embassy in China, with George Yeh, Vice-minister of Foreign Affairs, dated 26 July of 1948. 


\section{Appendixes}

\section{Maps}

\section{Map I}

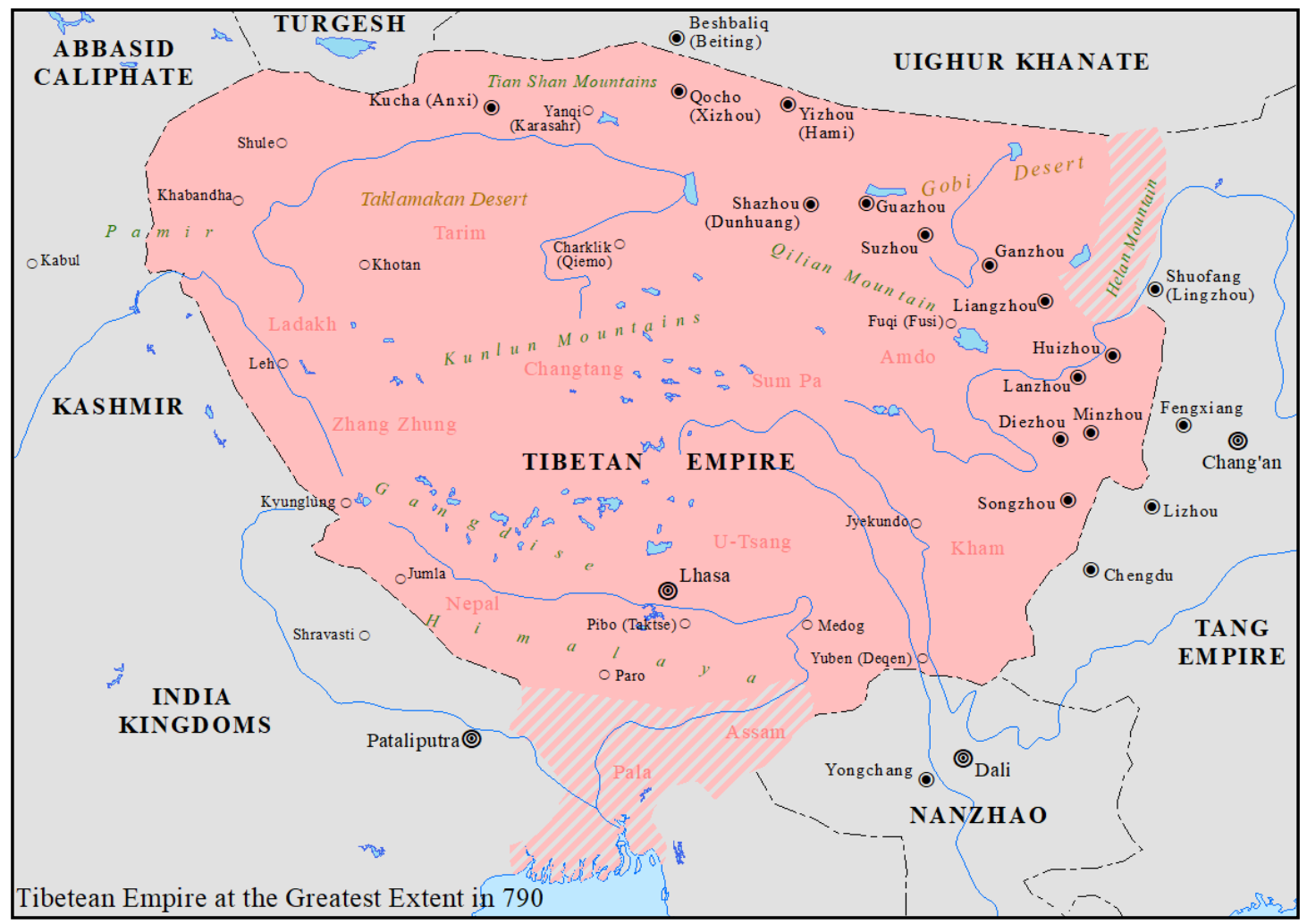

Tibetan Empire During the Tang Dynasty 
Map II

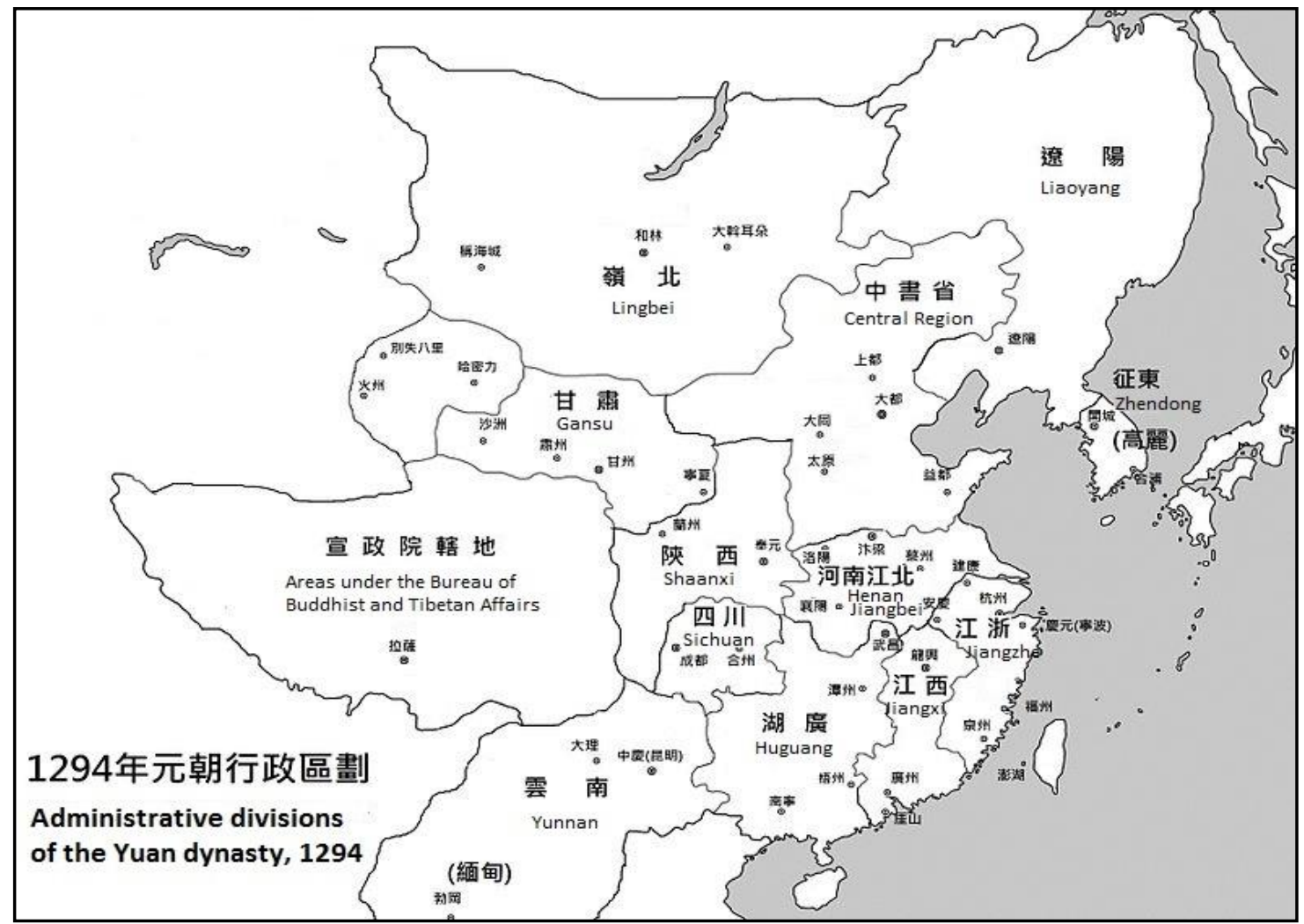

Tibet During the Yuan Empire 


\section{Map III}

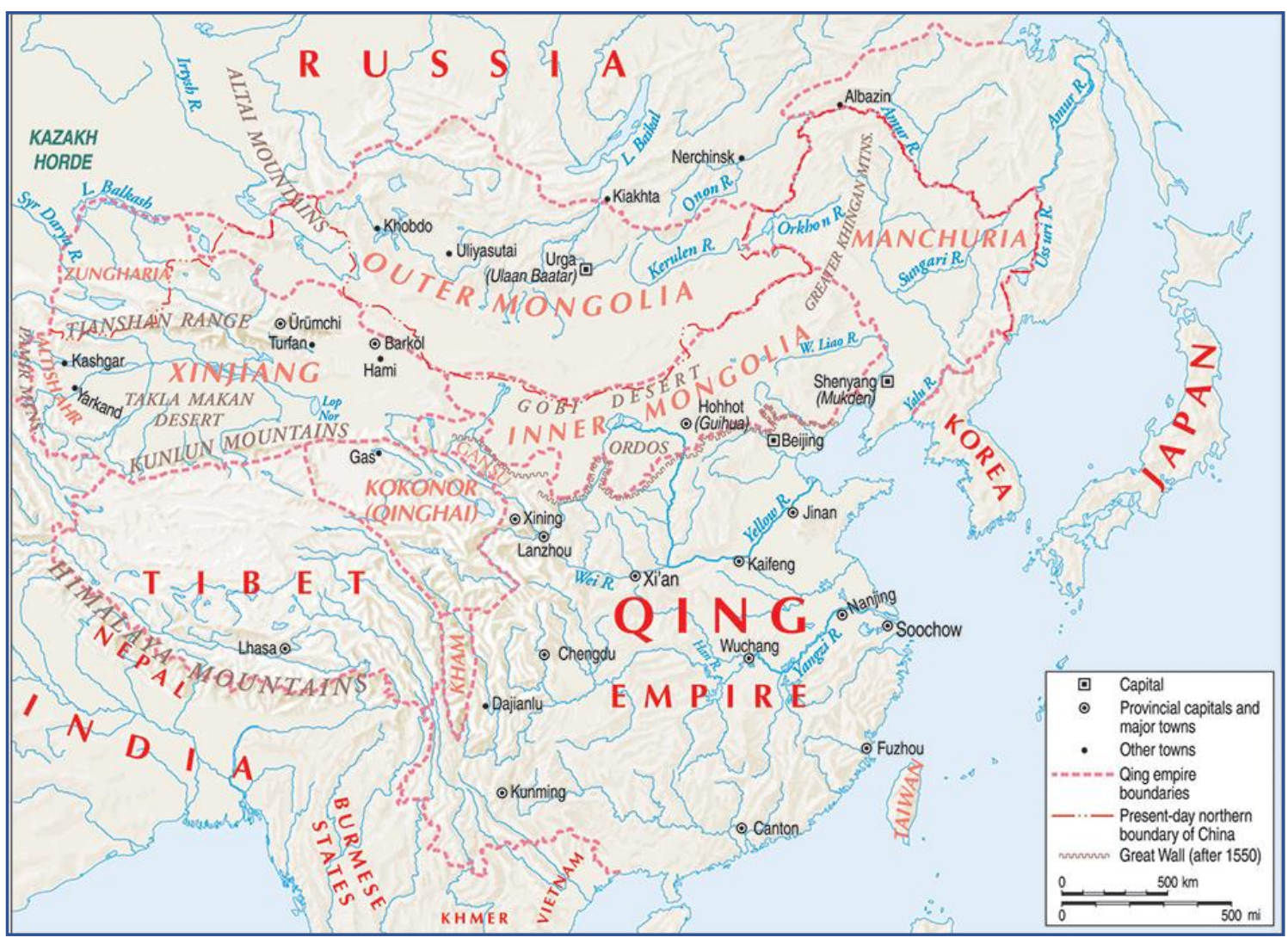

Tibet During the Qing Empire 


\section{Map IV}

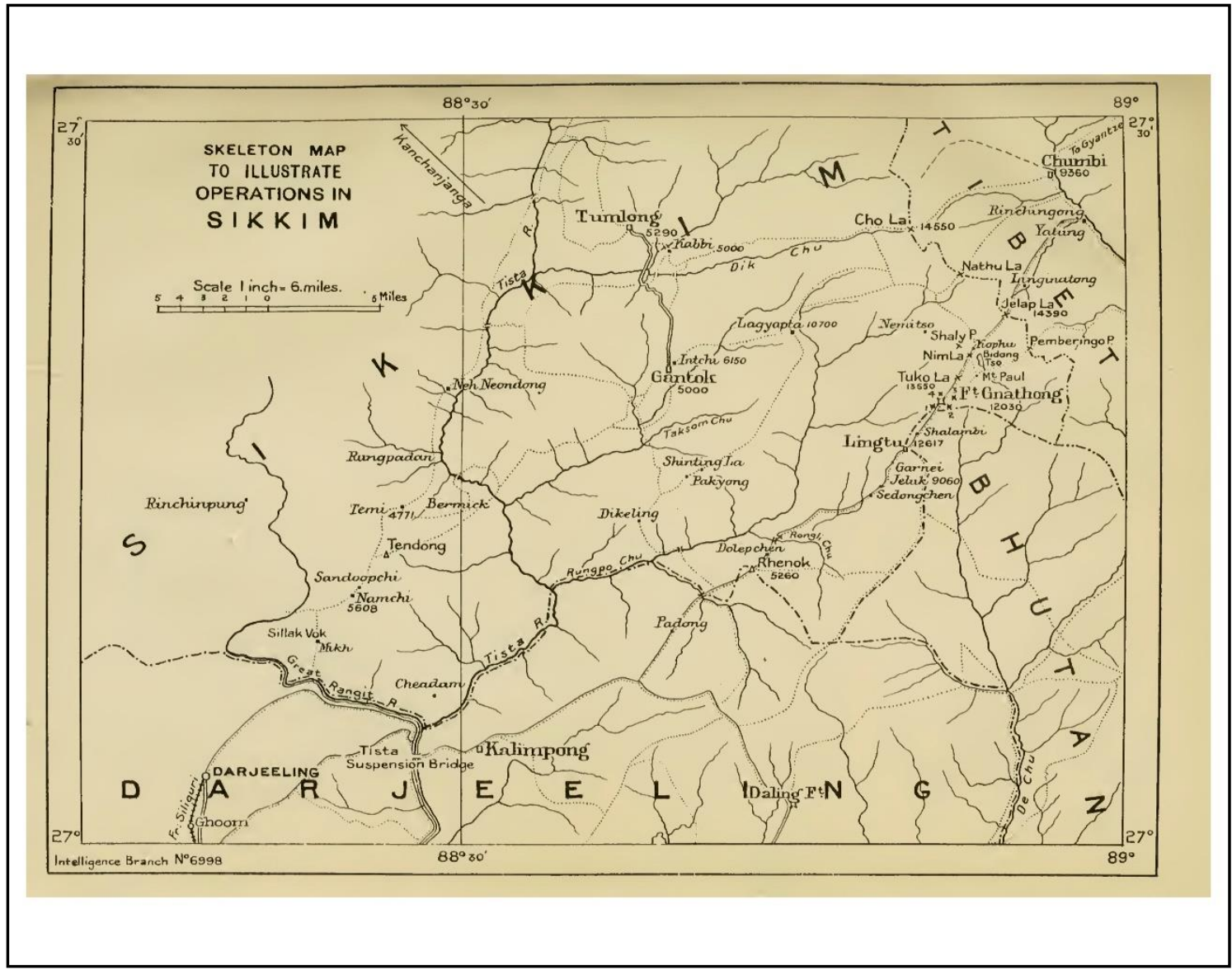

Map of Sikkim-Tibet in the Late Nineteenth Century 


\section{Map V}

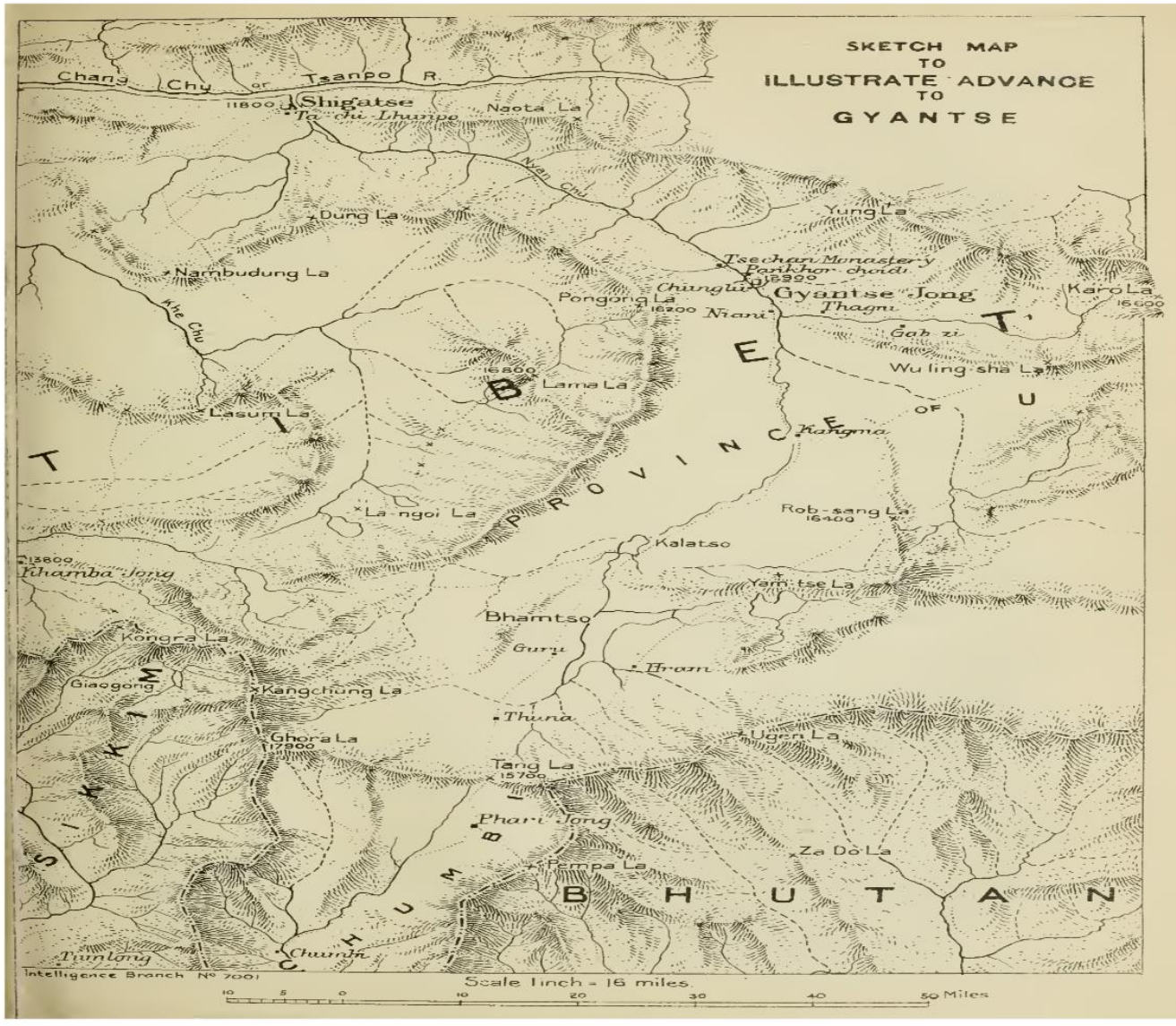

Map of British Expedition to Tibet 
Map VI

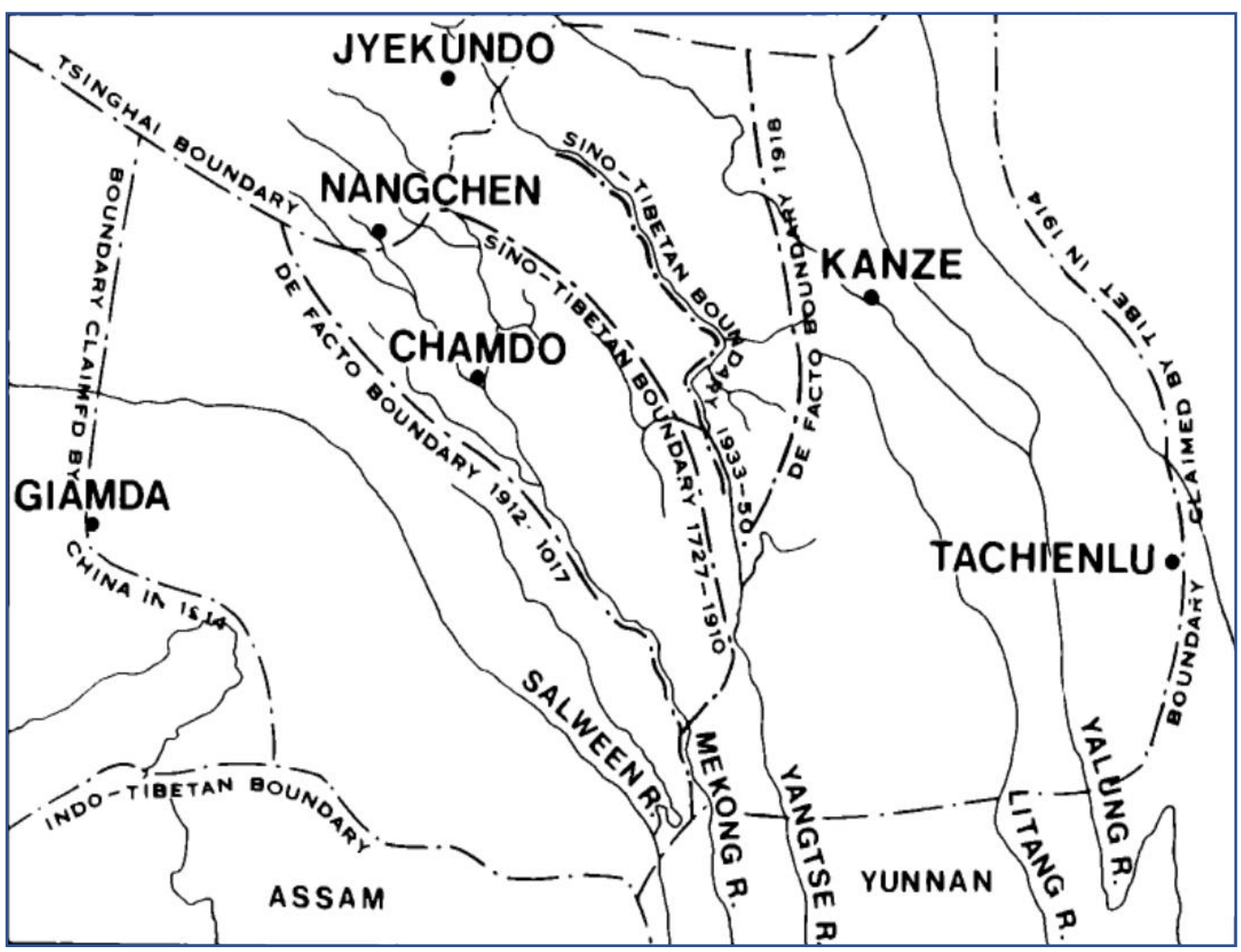

The Sino-Tibetan Boundary and the Tibet-India Boundary in the Simla Convention 
Map VII

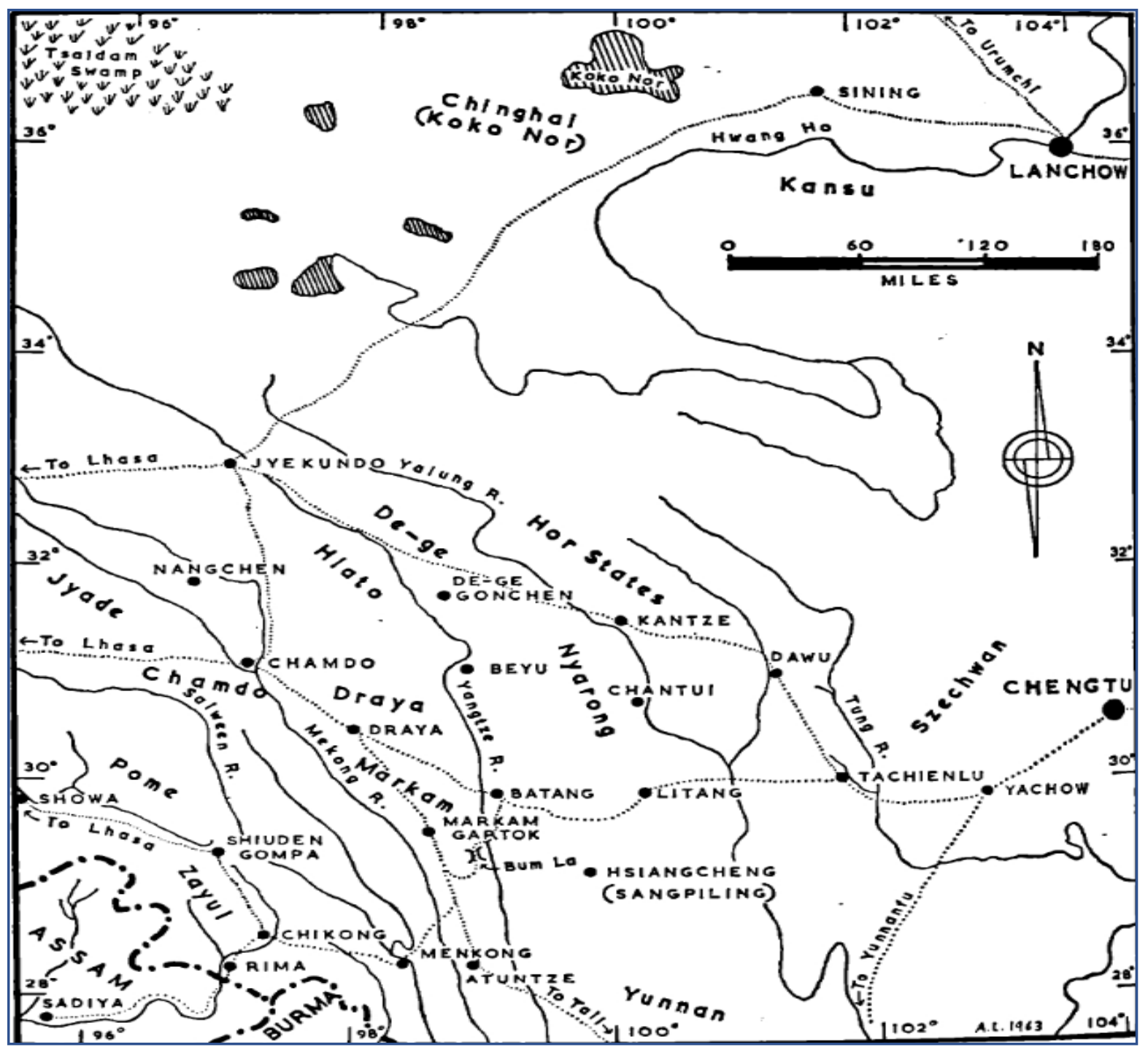

The Map of Kham During the Republican Era 
Map VIII

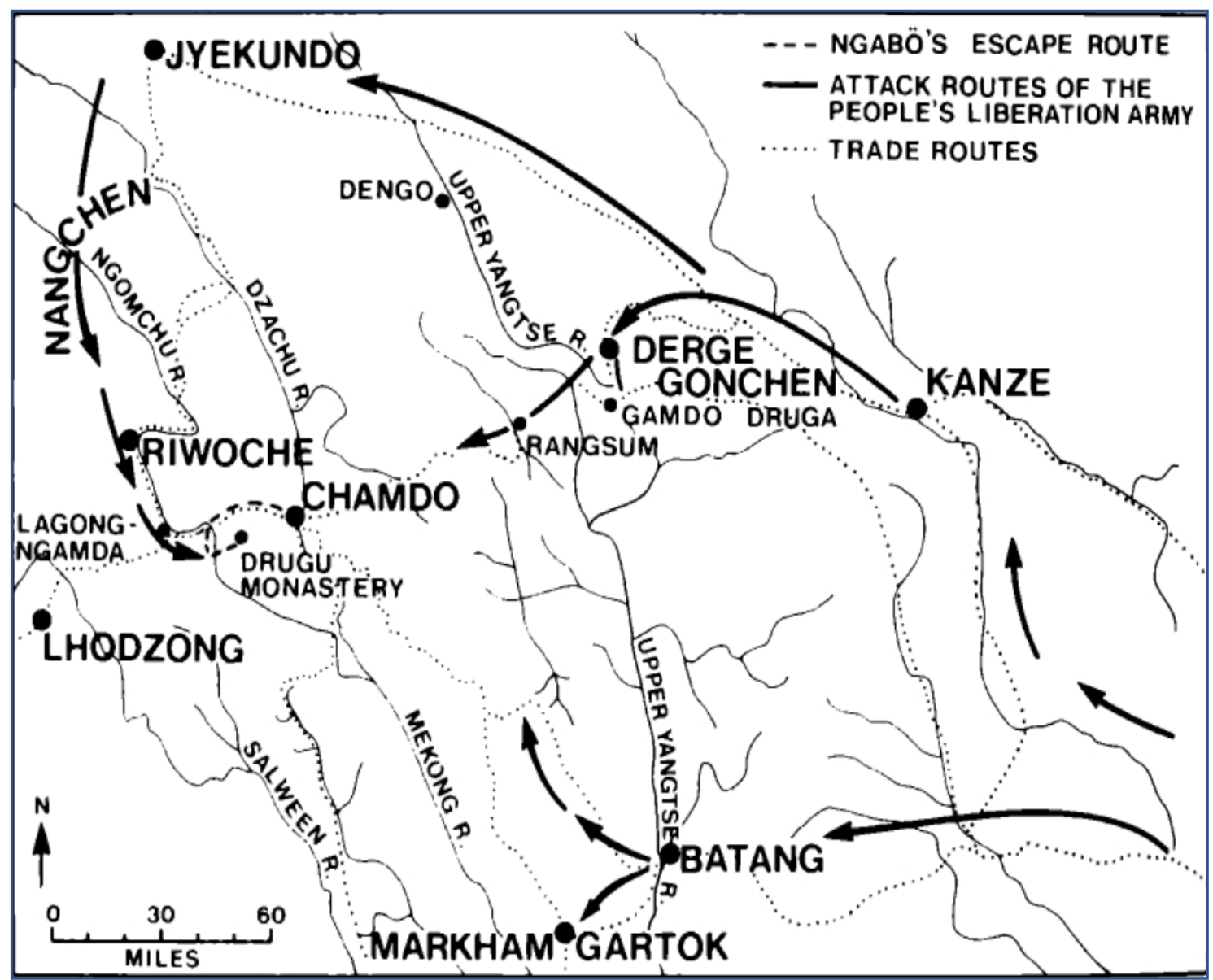

Attack Routes of the People's Liberation Army 


\title{
II. Tibet-Related Legal Documents
}

\section{Convention Between Great Britain and China Relating to Sikkim and Tibet} (1890)

\author{
Signed at Calcutta, 17 March 1890
}

Ratified at London, 27 August 1890

Whereas Her Majesty the Queen of the United Kingdom of Great Britain and Ireland, Empress of India, and His Majesty the Emperor of China, are sincerely desirous to maintain and perpetuate the relations of friendship and good understanding which now exist between their respective Empires; and whereas recent occurrences have tended towards a disturbance of the said relations, and it is desirable to clearly define and permanently settle certain matters connected with the boundary between Sikkim and Tibet, Her Britannic Majesty and His Majesty the Emperor of China have resolved to conclude a Convention on this subject, and have, for this purpose, named Plenipotentiaries, that is to say:

Her Majesty the Queen of Great Britain and Ireland, his Excellency the Most Honorable Henry Charles Keith Petty Fitzmaurice, G.M.S.I., G.C.M.G., G.M.I.E., Marquess of Lansdowne, Viceroy and Governor-General of India;

And His Majesty the Emperor of China, his Excellency Sheng Tai, Imperial Associate Resident in Tibet, Military Deputy Lieutenant-Governor;

Who, having met and communicated to each other their full powers, and finding these to be in proper form, have agreed upon the following Convention in eight Articles:

I. The boundary of Sikkim and Tibet shall be the crest of the mountain range separating the waters flowing into the Sikkim Teesta and its affluents from the waters flowing into the Tibetan Mochu and northwards into other rivers of Tibet. The line commences at Mount Gipmochi on the Bhutan frontier, and follows the above-mentioned waterparting to the point where it meets Nepal territory.

II. It is admitted that the British Government, whose Protectorate over the Sikkim State is hereby recognized, has direct and exclusive control over the internal administration and foreign relations of that State, and except through and with the permission of the British Government neither the Ruler of the State nor any of its officers shall have official relations of any kind, formal or informal, with any other country.

III. The Government of Great Britain and Ireland and the Government of China engage 
reciprocally to respect the boundary as defined in Article 1, and to prevent acts of Aggression from their respective sides of the frontier.

IV. The question of providing increased facilities for trade across the Sikkim-Tibet frontier will hereafter be discussed with a view to a mutually satisfactory arrangement by the High Contracting Powers.

V. The question of pasturage on the Sikkim side of the frontier is reserved for further examination and future adjustment.

VI. The High Contracting Powers reserve for discussion and arrangement the method in which official communications between the British authorities in India and the authorities in Tibet shall be conducted.

VII. Two joint Commissioners shall, within six months from the ratification of this Convention, be appointed, one by the British Government in India, the other by the Chinese Resident in Tibet. The said Commissioners shall meet and discuss the questions which, by the last three preceding Articles, have been reserved.

VIII. The present Convention shall be ratified, and the ratifications shall be exchanged in London as soon as possible after the date of the signature thereof.

In witness whereof the respective negotiators have signed the same, and affixed thereunto the seals of their arms.

Done in quadruplicate at Calcutta, this 17th day of March, in the year of our Lord 1890, corresponding with the Chinese date, the 27th day of the second moon of the 16th year of Kuang Hsu.

\section{Landsdowne}

Signature of the Chinese Plenipotentiary (Recite form Alastair Lamb, The McMahon Line: A Study in the Relations between India, China and Tibet, 1904 to 1914, Vol.1, 1966, pp 237-8.) 


\title{
Convention Between Great Britain and Tibet (1904)
}

\author{
Signed at Lhasa, 7 September, 1904
}

Whereas doubts and difficulties have arisen as to the meaning and validity of the AngloChinese Convention of 1890, and the Trade Regulations of 1893, and as to the liabilities of the Tibetan Government under these Agreements; and whereas recent occurrences have tended towards a disturbance of the relations of friendship and good understanding which have existed between the British Government and the Government of Tibet; and whereas it is desirable to restore peace and amicable relations, and to resolve and determine the doubts and difficulties as aforesaid, the said Governments have resolved to conclude a Convention with these objects, and the following Articles have been agreed upon by Colonel F.E. Younghusband, C.I.E., in virtue of full powers vested in him by His Britannic Majesty's Government and on behalf of that said Government, and Losang Gyal-Tsen, the Ga-den Ti-Rimpoche, and the Representatives of the Council of the three monasteries, Sera, Dre-pung, and Ga-den, and of the ecclesiastical and lay officials of the National Assembly on behalf of the Government of Tibet.

I. The Government of Tibet engages to respect the Anglo-Chinese Convention of 1890 and to recognize the frontier between Sikkim and Tibet, as defined in Article I of the said Convention, and to erect boundary pillars accordingly.

II. The Tibetan Government undertakes to open forthwith trade marts to which all British and Tibetan subjects shall have free right of access at Gyangtse and Gartok, as well as at Yatung.

The Regulations applicable to the trade mart at Yatung, under the Anglo-Chinese Agreement of 1893, shag, subject to such amendments as may hereafter be agreed upon by common consent between the British and Tibetan Governments, apply to the marts above mentioned.

In addition to establishing trade marts at the places mentioned, the Tibetan Government undertakes to place no restrictions on the trade by existing routes, and to consider the question of establishing fresh trade marts under similar conditions if development of trade requires it.

III. The question of the amendment of the Regulations of 1893 is reserved for separate consideration, and the Tibetan Government undertakes to appoint fully authorized Delegates to negotiate with the Representatives of the British Government as to the details of the amendments required.

IV. The Tibetan Government undertakes to levy no dues of any kind other than those provided for in the tariff to be mutually agreed upon. 
V. The Tibetan Government undertakes to keep the roads to Gyangtse and Gartok from the frontier clear of all obstruction and in a state of repair suited to the needs of the trade, and to establish at Yatung, Gyangtse, and Gartok, and at each of the other trade marts that may hereafter be established, a Tibetan Agent, who shall receive from the British Agent appointed to watch over British trade at the marts in question any letter which the latter may desire to send to the Tibetan or to the Chinese authorities. The Tibetan Agent shall also be responsible for the due delivery of such communications and for the transmission of replies.

VI. As an indemnity to the British Government for the expense incurred in the dispatch of armed troops to Lhasa, to exact reparation for breaches of Treaty obligations and for the insults offered to and attacks upon the British Commissioner and his following and escort, the Tibetan Government engages to pay a sum of 500,0001-equivalent to 75 lakhs of rupees-to the British Government.

The indemnity shall be payable at such places as the British Government may from time to time, after due notice, indicate, whether in Tibet or in the British districts of Darjeeling or Jalpaiguri, in seventy-five annual installments of 1lakh of rupees each, on the 1st January in each year, beginning from the 1st January, 1906.

VII. As security for the payment of the above-mentioned indemnity and for the fulfillment of the provisions relative to trade marts specified in Articles II, III, IV and IV, the British Government shall continue to occupy the Chumbi Valley until the indemnity has been paid, and until the trade marts have been effectively opened for three years, whichever date may be the later.

VIII. The Tibetan Government agrees to raze all forts and fortifications and remove all armaments which might impede the course of free communication between the British frontier and the towns of Gyangtse and Lhasa.

IX. The Government of Tibet engages that, without the previous consent of the British Government.

a. No portion of Tibetan territory shall be ceded, sold, leased, mortgaged or otherwise given for occupation, to any foreign Power;

b. No such Power shall be permitted to intervene in Tibetan affairs;

c. No Representatives or Agents of any foreign Power shall be admitted to Tibet;

d. No concessions for railways, roads, telegraphs, mining or other rights, shall be granted to any foreign Power, or the subject of any foreign Power. In the event of consent to such concessions being granted, similar or equivalent concessions shall be granted to the British Government; 
e. No Tibetan revenues, whether in kind or in cash, shall be pledged or assigned to any foreign Power, or to the subject of any foreign Power.

$X$. In witness whereof the negotiators have signed the same, and affixed thereunto the seals of their arms.

Done in quintuplicate at Lhasa, this 7th day of September, in the year of our Lord 1904, corresponding with the Tibetan date, the 27th of the 7th month of the Wood Dragon year.

(Seal of Dalai Lama, affixed by the Ga-den Ti-Rimpoche)

(Seal of Tibet Frontier Commission)

(Seal of British Commissioner)

(Seal of Council)

(Seal of the Dre-pung Monastery)

(Seal of Se-ra Monastery)

(Seal of Ga-den Monastery)

(Seal of National Assembly)

F.E. Younghusband, Colonel, British Commissioner (Recite form Alastair Lamb, The McMahon Line: A Study in the Relations between India, China and Tibet, 1904 to 1914, Vol.1, 1966, pp 242-5.) 


\section{Convention Between Great Britain and China Respecting Tibet (1906)}

Signed at Peking, 27 April 1906

Ratified at London, 23 July 1906

Whereas His Majesty the King of Great Britain and Ireland and of the British Dominions beyond the Seas, Emperor of India, and His Majesty the Emperor of China are sincerely desirous to maintain and perpetuate the relations of friendship and good understanding which now exist between their respective Empires;

And whereas the refusal of Tibet to recognize the validity of or to carry into full effect the provisions of the Anglo-Chinese Conventions of March 17, 1890 and Regulations of December 5, 1893 placed the British Government under the necessity of taking steps to secure their rights and interests under the said Convention and Regulations;

And whereas a Convention of ten Articles was signed at Lhasa on September 7, 1904 on behalf of Great Britain and Tibet, and was ratified by the Viceroy and GovernorGeneral of India on behalf of Great Britain on November 11, 1904, a declaration on behalf of Great Britain modifying its terms under certain conditions being appended thereto;

His Britannic Majesty and His Majesty the Emperor of China have resolved to conclude a Convention on this subject and have for this purpose named Plenipotentiaries, that is to say--His Majesty the King of Great Britain and Ireland: Sir Ernest Mason Satow, Knight Grand Cross of the Most Distinguished Order of Saint Michael and Saint George, His said Majesty's Envoy Extraordinary and Minister Plenipotentiary to His Majesty the Emperor of China; And His Majesty the Emperor of China: His Excellency Tong Shoa-yi, His said Majesty's High Commissioner Plenipotentiary and a Vice-President of the Board of Foreign Affairs--who having communicated to each other their respective full powers and finding them to be in good and true form have agreed upon and concluded the following Convention in six Articles.

Art. I. The Convention concluded on September 7, 1904 by Great Britain and Tibet, the texts of which in English and Chinese are attached to the present Convention as an annex, is hereby confirmed, subject to the modification stated in the declaration appended thereto, and both of the High Contracting Parties engage to take at all times such steps as may be necessary to secure the due fulfillment of the terms specified therein.

II. The Government of Great Britain engages not to annex Tibetan territory or to interfere in the administration of Tibet. The Government of China also undertakes not to permit any other foreign State to interfere with the territory or internal administration of Tibet. 
III. The Concessions which are mentioned in Article IX (d) of the Convention concluded on September 7, 1904 by Great Britain and Tibet are denied to any State or to the subject of any State other than China, but it has been arranged with China that at the trade marts specified in Article II of the aforesaid Convention Great Britain shall be entitled to lay down telegraph lines connecting with India.

IV. The provisions of the Anglo-Chinese Convention of 1890 and Regulations of 1893 shall, subject to the terms of this present Convention and annex thereto, remain in full force.

V. The English and Chinese texts of the present Convention have been carefully compared and found to correspond but in the event of there being any difference of meaning between them the English text shall be authoritative.

VI. This Convention shall be ratified by the Sovereigns of both countries and ratifications shall be exchanged at London within three months after the date of signature by the Plenipotentiaries of both Powers.

In token whereof the respective Plenipotentiaries have signed and sealed this Convention, four copies in English and four in Chinese.

Done at Peking this twenty-seventh day of April, one thousand nine hundred and six, being the fourth day of the fourth month of the thirty-second year of the reign of Kuanghsu.

(L.S.) Ernest Satow

(Signature and Seal of the Chinese Plenipotentiary) (Recite form Alastair Lamb, The McMahon Line: A Study in the Relations between India, China and Tibet, 1904 to 1914, Vol.1, 1966, pp 247-9.) 


\section{Convention Between Great Britain and Russia (1907)}

Signed at St. Petersburg on the 18th (31st) August 1907

His Majesty the King of the United Kingdom of Great Britain and Ireland and of the British Dominions beyond the Seas, Emperor of India, and His Majesty the Emperor of All the Russians, animated by the sincere desire to settle by mutual agreement different questions concerning the interests of their States on the Continent of Asia, have determined to conclude Agreements destined to prevent all cause of misunderstanding between Great Britain and Russia in regard to the questions referred to, and have nominated for this purpose their respective Plenipotentiaries, to wit:

His Majesty the King of the United Kingdom of Great Britain and Ireland and of the British Dominions beyond the Seas, Emperor of India, the Right Honorable Sir Arthur Nicolson, His Majesty's Ambassador Extraordinary and Plenipotentiary to His Majesty the Emperor of All the Russians;

His Majesty the Emperor of All the Russians, the Master of his Court Alexander Iswolsky, Minister for Foreign Affairs;

Who, having communicated to each other their full powers, found in good and due form, have agreed on the following.

Arrangement Concerning Tibet

The Governments of Great Britain and Russia recognizing the suzerain rights of China in Thibet, and considering the fact that Great Britain, by reason of her geographical position, has a special interest in the maintenance of the status quo in the external relations of Thibet, have made the following arrangement.

Article I. The two High Contracting Parties engage to respect the territorial integrity of Tibet and to abstain from all interference in the internal administration.

Article II. In conformity with the admitted principle of the suzerainty of China over Tibet, Great Britain and Russia engage not to enter into negotiations with Tibet except through the intermediary of the Chinese Government. This engagement does not exclude the direct relations between British Commercial Agents and the Tibetan authorities provided for in Article V of the Convention between Great Britain and Tibet of the 7th September 1904, and confirmed by the Convention between Great Britain and China of the 27th April 1906; nor does it modify the engagements entered into by Great Britain and China in Article I of the said Convention of 1906.

It is dearly understood that Buddhists, subjects of Great Britain or of Russia, may enter into direct relations on strictly religious matters with the Dalai Lama and the other 
representatives of Buddhism in Tibet; the Governments of Great Britain and Russia engage, as far as they are concerned, not to allow those relations to infringe the stipulations of the present arrangement.

Article III. The British and Russian Governments respectively engage not to send Representatives to Lhasa.

Article IV. The two High Contracting Parties engage neither to seek nor to obtain, whether for themselves or their subjects, any Concessions for railways, roads, telegraphs, and mines, or other rights in Tibet.

Article V. The two Governments agree that no part of the revenues of Tibet, whether in kind or in cash, shall be pledged or assigned to Great Britain or Russia or to any of their subjects. (Recite form Alastair Lamb, The McMahon Line: A Study in the Relations between India, China and Tibet, 1904 to 1914, Vol.1, 1966, pp 251-6.) 


\title{
Convention Between Great Britain, China, and Tibet, Simla (1914)
}

\author{
Simla 1914
}

His Majesty the King of the United Kingdom of Great Britain and Ireland and of the British Dominions beyond the Seas, Emperor of India, His Excellency the President of the Republic of China, and His Holiness the Dalai Lama of Tibet, being sincerely desirous to settle by mutual agreement various questions concerning the interests of their several States on the Continent of Asia, and further to regulate the relations of their several Governments, have resolved to conclude a Convention on this subject and have nominated for this purpose their respective Plenipotentiaries, that is to say:

His Majesty the King of the United Kingdom of Great Britain and Ireland and of the British Dominions beyond the Seas, Emperor of India, Sir Arthur Henry McMahon, Knight Grand Cross of the Royal Victorian Order, Knight Commander of the Most Eminent Order of the Indian Empire, Companion of the Most Exalted Order of the Star of India, Secretary to the Government of India, Foreign and Political Department;

His Excellency the President of the Republic of China, Monsieur Ivan Chen, Officer of the Order of the Chia Ho;

His Holiness the Dalai Lama of Tibet, Lonchen Ga-den Shatra Pal-jor Dorje; who having communicated to each other their respective full powers and finding them to be in good and due form have agreed upon and concluded the following Convention in eleven Articles.

Article 1. The Conventions specified in the Schedule to the present Convention shall, except in so far as they may have been modified by, or may be inconsistent with or repugnant to, any of the provisions of the present Convention, continue to be binding upon the High Contracting Parties.

Article 2. The Governments of Great Britain and China recognizing that Tibet is under the suzerainty of China, and recognizing also the autonomy of Outer Tibet, engage to respect the territorial integrity of the country, and to abstain from interference in the administration of Outer Tibet (including the selection and installation of the Dalai Lama), which shall remain in the hands of the Tibetan Government at Lhasa.

The Government of China engages not to convert Tibet into a Chinese province. The Government of Great Britain engages not to annex Tibet or any portion of it.

Article 3. Recognizing the special interest of Great Britain, in virtue of the geographical position of Tibet, in the existence of an effective Tibetan Government, and in the maintenance of peace and order in the neighbourhood of the frontiers of India and adjoining States, the Government of China engages, except as provided in Article 4 of 
this Convention, not to send troops into Outer Tibet, nor to station civil or military officers, nor to establish Chinese colonies in the country. Should any such troops or officials remain in Outer Tibet at the date of the signature of this Convention, they shall be withdrawn within a period not exceeding three months.

The Government of Great Britain engages not to station military or civil officers in Tibet (except as provided in the Convention of September 7, 1904, between Great Britain and Tibet) nor troops (except the Agents' escorts), nor to establish colonies in that country.

Article 4. The foregoing Article shall not be held to preclude the continuance of the arrangement by which, in the past, a Chinese high-official with suitable escort has been maintained at Lhasa, but it is hereby provided that the said escort shall in no circumstances exceed 300 men.

Article 5. The Governments of China and Tibet engage that they will not enter into any negotiations or agreements regarding Tibet with one another, or with any other Power, excepting such negotiations and agreements between Great Britain and Tibet as are provided for by the Convention of September 7, 1904, between Great Britain and Tibet and the Convention of April 27, 1906, between Great Britain and China.

Article 6. Article III of the Convention of April 27, 1906, between Great Britain and China is hereby cancelled, and it is understood that in Article IX(d) of the Convention of September 7, 1904, between Great Britain and Tibet the term 'Foreign Power' does not include China.

Not less favourable treatment shag be accorded to British commerce than to the commerce of China or the most favoured nation.

Article 7.a. The Tibet Trade Regulations of 1893 and 1908 are hereby cancelled.

b. The Tibetan Government engages to negotiate with the British Government new Trade Regulations for Outer Tibet to give effect to Articles II, IV and V of the Convention of September 7, 1904, between Great Britain and Tibet without delay; provided always that such Regulations shall in no way modify the present Convention except with the consent of the Chinese Government.

Article 8. The British Agent who resides at Gyantse may visit Lhasa with his escort whenever it is necessary to consult with the Tibetan Government regarding matters arising out of the Convention of September 7, 1904, between Great Britain and Tibet, which it has been found impossible to settle at Gyantse by correspondence or otherwise.

Article 9. For the purpose of the present Convention the borders of Tibet, and the boundary between Outer and Inner Tibet, shall be as shown in red and blue respectively 
on the map attached hereto.

Nothing in the present Convention shag be held to prejudice the existing rights of the Tibetan Government in Inner Tibet, which include the power to select and appoint the high priests of monasteries and to retain full control in all matters affecting religious institutions.

Article 10. The English, Chinese and Tibetan texts of the present Convention have been carefully examined and found to correspond, but in the event of there being any difference of meaning between them the English text shall be authoritative.

Article 11. The present Convention will take effect from the date of signature.

In token whereof the respective Plenipotentiaries have signed and sealed this Convention, three copies in English, three in Chinese and three in Tibetan.

Done at Simla this third day of July, A.D., one thousand nine hundred and fourteen, corresponding with the Chinese date, the third day of the seventh month of the third year of the Republic, and the Tibetan date, the tenth day of the fifth month of the WoodTiger year.

Initial of the Lonchen Shatra

Seal of the Lonchen Shatra Seal of the British

Plenipotentiary (Recite form FO/535/17, No. 231, enclosure 8) 


\title{
Seventeen-Point Plan for the Peaceful Liberation of Tibet (1951)
}

\author{
23 May, 1951
}

The Tibetan nationality is one of the nationalities with a long history within the boundaries of China and, like many other nationalities, it has done its glorious duty in the course of the creation and development of the great motherland. But over the last hundred years and more, imperialist forces penetrated into China, and in consequence, also penetrated into the Tibetan region and carried out all kinds of deceptions and provocations. Like previous reactionary Governments, the KMT [p.Kuomintang] reactionary government continued to carry out a policy of oppression and sowing dissension among the nationalities, causing division and disunity among the Tibetan people. The Local Government of Tibet did not oppose imperialist deception and provocations, but adopted an unpatriotic attitude towards the great motherland. Under such conditions, the Tibetan nationality and people were plunged into the depths of enslavement and suffering. In 1949, basic victory was achieved on a nation-wide scale in the Chinese people's war of liberation; the common domestic enemy of all nationalities--the KMT reactionary government--was overthrown; and the common foreign enemy of all nationalities--the aggressive imperialist forces--was driven out. On this basis, the founding of the People's Republic of China and of the Central People's Government was announced. In accordance with the Common Programme passed by the Chinese People's Political Consultative Conference, the Central People's Government declared that all nationalities within the boundaries of the People's Republic of China are equal, and that they shall establish unity and mutual aid and oppose imperialism and their own public enemies, so that the People's Republic of China may become one big family of fraternity and cooperation, composed of all its nationalities. Within this big family of nationalities of the People's Republic of China, national regional autonomy is to be exercised in areas where national minorities are concentrated, and all national minorities are to have freedom to develop their spoken and written languages and to preserve or reform their customs, habits, and religious beliefs, and the Central People's Government will assist all national minorities to develop their political, economic, cultural, and educational construction work. Since then, all nationalities within the country, with the exception of those in the areas of Tibet and Taiwan, have gained liberation. Under the unified leadership of the Central People's Government and the direct leadership of the higher levels of People's Governments, all national minorities have fully enjoyed the right of national equality and have exercised, or are exercising, national regional autonomy. In order that the influences of aggressive imperialist forces in Tibet may be successfully eliminated, the unification of the territory and sovereignty of the People's Republic of China accomplished, and national defence safeguarded; in order that the Tibetan nationality and people may be freed and return to the big family of the People's Republic of China to enjoy the same rights of national equality as all other nationalities in the country and develop their political, economic, cultural, and educational work, the Central People's Government, when it ordered the People's Liberation Army to march into Tibet, notified the local government 
of Tibet to send delegates to the Central Authorities to hold talks for the conclusion of an agreement on measures for the peaceful liberation of Tibet. At the latter part of April, 1951, the delegates with full powers from the Local Government of Tibet arrived in Peking. The Central People's Government appointed representatives with full powers to conduct talks on a friendly basis with the delegates of the Local Government of Tibet. The result of the talks is that both parties have agreed to establish this agreement and ensure that it be carried into effect.

1. The Tibetan people shall be united and drive out the imperialist aggressive forces from Tibet; that the Tibetan people shall return to the big family of the motherland--the People's Republic of China.

2. The Local Government of Tibet shall actively assist the People's Liberation Army to enter Tibet and consolidate the national defences.

3. In accordance with the policy towards nationalities laid down in the Common Programme of the Chinese People's Political Consultative Conference, the Tibetan people have the right of exercising national regional autonomy under the unified leadership of the Central People's Government.

4. The Central Authorities will not alter the existing political system in Tibet. The Central Authorities also will not alter the established status, functions and powers of the Dalai Lama. Officials of various ranks shall hold office as usual.

5. The established status, functions, and powers of the Panchen Ngoerhtehni shall be maintained.

6. By the established status, functions and powers of the Dalai Lama and of the Panchen Ngoerhtehni is meant the status, functions and powers of the 13th Dalai Lama and of the 9th Panchen Ngoerhtehni when they were in friendly and amicable relations with each other.

7. The policy of freedom of religious belief laid down in the Common Programme of the Chinese People's Political Consultative Conference will be protected. The Central Authorities will not effect any change in the income of the monasteries.

8. The Tibetan troops will be reorganised step by step into the People's Liberation Army, and become a part of the national defence forces of the Central People's Government.

9. The spoken and written language and school education of the Tibetan nationality will be developed step by step in accordance with the actual conditions in Tibet.

10. Tibetan agriculture, livestock raising, industry and commerce will be developed step by step, and the people's livelihood shall be improved step by step in accordance 
with the actual conditions in Tibet.

11. In matters related to various reforms in Tibet, there will be no compulsion on the part of the Central Authorities. The Local Government of Tibet should carry out reforms of its own accord, and when the people raise demands for reform, they must be settled through consultation with the leading personnel of Tibet.

12. In so far as former pro-imperialist and pro-KMT officials resolutely sever relations with imperialism and the KMT and do not engage in sabotage or resistance, they may continue to hold office irrespective of their past.

13. The People's Liberation Army entering Tibet will abide by the above-mentioned policies and will also be fair in all buying and selling and will not arbitrarily take even a needle or a thread from the people.

14. The Central People's Government will handle all external affairs of the area of Tibet; and there will be peaceful co-existence with neighboring countries and the establishment and development of fair commercial and trading relations with them on the basis of equality, mutual benefit and mutual respect for territory and sovereignty.

15. In order to ensure the implementation of this agreement, the Central People's Government will set up a military and administrative committee and a military area headquarters in Tibet, and apart from the personnel sent there by the Central People's Government it will absorb as many local Tibetan personnel as possible to take part in the work. Local Tibetan personnel taking part in the military and administrative committee may include patriotic elements from the Local Government of Tibet, various district and various principal monasteries; the name list is to be prepared after consultation between the representatives designated by the Central People's Government and various quarters concerned, and is to be submitted to the Central People's Government for approval.

16. Funds needed by the military and administrative committee, the military area headquarters and the People's Liberation Army entering Tibet will be provided by the Central People's Government. The Local Government of Tibet should assist the People's Liberation Army in the purchases and transportation of food, fodder, and other daily necessities.

17. This agreement shall come into force immediately after signatures and seals are affixed to it.

Signed and sealed by delegates of the Central People's Government with full powers:

Chief Delegate: Li Wei-han (Chairman of the Commission of Nationalities Affairs); 
Delegates: Chang Ching-wu, Chang Kuo-hua, Sun Chih-yuan Delegates with full powers of the Local Government of Tibet:

Chief Delegate: Kaloon Ngabou Ngawang Jigme (Ngabo Shape) (Recite from http://www.tibetjustice.org/materials/china/china3.html) 



\section{Curriculum Vitae}

Chenyu Wang (1989) was born in Hefei, China. Before studying in the Netherlands, he initiated his undergraduate study at West Anhui University (China) in 2008, where he obtained a Bachelor of Law in 2012. Then he obtained his master degree in international law from Zhongnan University of Economics and Law (China) in 2015. Since 1 October 2016, he started to carry out his $\mathrm{PhD}$ research at the school of law of Utrecht University as a member of the IER Department. His $\mathrm{PhD}$ research is funded by the China Scholarship Council (CSC). This thesis is the outcome of his $\mathrm{PhD}$ research. 